\title{
"The Entire Army Says Hello": Common Soldiers' Experiences, Localism, and Army Reform in Britain and Prussia, 1739-1789
}

Alexander S. Burns

West Virginia University, asburns@mix.wvu.edu

Follow this and additional works at: https://researchrepository.wvu.edu/etd

Part of the European History Commons, History of Religion Commons, Military History Commons, and the Social History Commons

\section{Recommended Citation}

Burns, Alexander S., "'The Entire Army Says Hello": Common Soldiers' Experiences, Localism, and Army Reform in Britain and Prussia, 1739-1789" (2021). Graduate Theses, Dissertations, and Problem Reports. 8080.

https://researchrepository.wvu.edu/etd/8080

This Dissertation is protected by copyright and/or related rights. It has been brought to you by the The Research Repository @ WVU with permission from the rights-holder(s). You are free to use this Dissertation in any way that is permitted by the copyright and related rights legislation that applies to your use. For other uses you must obtain permission from the rights-holder(s) directly, unless additional rights are indicated by a Creative Commons license in the record and/ or on the work itself. This Dissertation has been accepted for inclusion in WVU Graduate Theses, Dissertations, and Problem Reports collection by an authorized administrator of The Research Repository @ WVU.

For more information, please contact researchrepository@mail.wvu.edu. 
"The Entire Army Says Hello":

Common Soldiers' Experiences, Localism, and Army Reform in Britain and Prussia, 1739-1789

Alexander S. Burns

\author{
A Dissertation submitted \\ to the Eberly College of Arts and Sciences \\ at West Virginia University \\ in partial fulfillment of the requirements for the degree of \\ Doctor in History \\ Katherine B. Aaslestad, Ph.D., Chair \\ Matthew Vester, Ph.D., Co-Chair \\ Tyler Boulware, Ph.D. \\ Joseph M. Hodge, Ph.D. \\ Max Flomen, Ph.D. \\ Michael V. Leggiere, Ph.D. \\ Department of History
}

\title{
Morgantown, West Virginia
}

2021

Keywords: Britain; Prussia; Army; Soldiers; Common; Letters; Eighteenth Century; Copyright 2021 Alexander Samuel Burns 


\title{
ABSTRACT \\ The Entire Army Says Hello": \\ Common Soldiers' Experiences, Localism, and Army Reform in Britain and Prussia, 1739-1789
}

\begin{abstract}
Alexander S. Burns
This dissertation fundamentally questions the state of the field regarding militaries, state building, and narratives of modernity in the Kingdoms of Britain and Prussia. An examination of military stereotyping, common soldiers' correspondence, religion, localism, and army reform all suggests that the British and Prussian militaries were mutually-intelligible and similar, not radically different. This similarity has broad implications for the modern history of these two European states. Britain was not on a straight road to whiggish parliamentary progress, and Prussia was not on a straight road to militarism and authoritarian rule. Rather, in second half of the eighteenth century, both of these military-fiscal states utilized their religious rural subjects, drawn from their village communities, as the basis of their military strength. Forming part of a growing scholarly revolution regarding eighteenth-century common soldiers, this dissertation relies on soldiers' letters drawn from archives across the United Kingdom, Germany, and the Atlantic World. "The Entire Army Says Hello" demonstrates that soldiers in Britain and Prussia experienced broad similarities in their military service, and those similarities offer a new framework for the national history of these two states.
\end{abstract}




\section{Table of Contents}

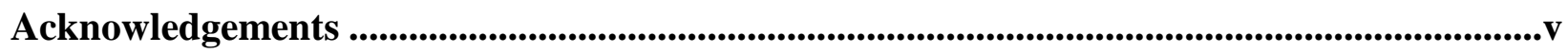

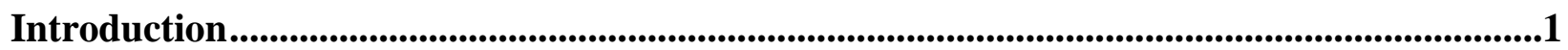

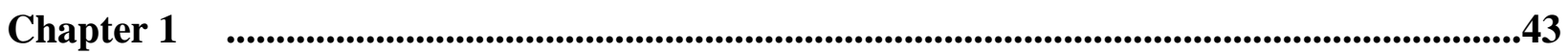

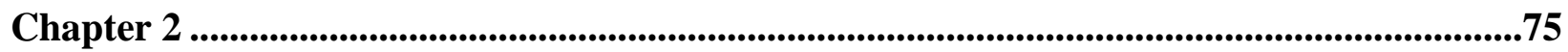

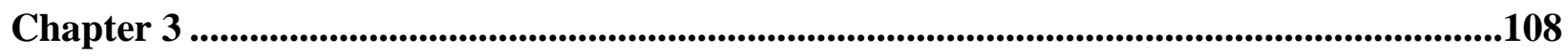

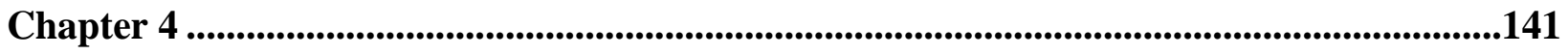

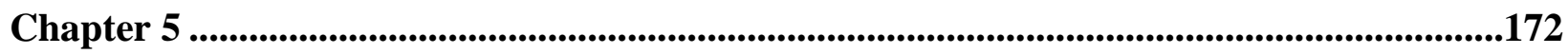

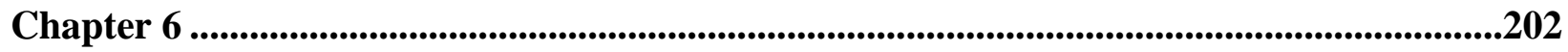

Chapter 7 .........................................................................................................................................................236

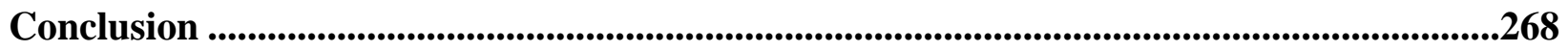

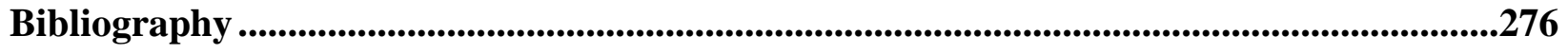


For Noelle and Katherine 


\section{Acknowledgements}

Like a Fahnenjunker from a poor Pomeranian family who had recently arrived in Berlin, the doctoral student writing a dissertation naturally incurs a great many debts. Over the past six years, I have benefitted from the knowledge, kindness, wisdom, and charity of more individuals than I can count. My life would not be the same without their support, and certainly this dissertation would never have been completed. My parents, Leslee and Patrick Burns, sparked my interest in history. My mother has a great talent for reading aloud, and G.A. Henty's nineteenth-century historical fiction was the one of the roots of my interest in the past. My parents provided the bedrock for my interest in history to grow, and I will always be grateful for this gift. All of my grandparents, particularly George Hull Haden and Shirlee Kirk Haden, fostered my love of the past in conversations about their lives during the turmoil of the twentieth century.

My professional training in history began at Indiana Wesleyan University, studying with Professors Mark A. Smith, David K. Burden, and David Bartley. They modeled the excellence in undergraduate education, and my syllabi and teaching style are heavily in their debt. Drs. Daniel Ingram, Sergei Zhuk and Nicole Etcheson continued the work of developing me as a scholar during my education at Ball State University between 2012 and 2014. My work was further sharpened in the classrooms of Drs. Tyler Boulware, Brian Luskey, Joseph Hodge, and James Siekmeier at West Virginia University, where I began my doctoral studies in 2015. The process of gaining an education begins with classroom instruction, and I have been fortunate enough to sit in many classrooms with my advisor, Dr. Katherine Aaslestad. Her instruction, patience, endurance, and above all, her kindness, have made my educational journey at West Virginia University a truly memorable one. She and her wonderful husband John Lambertson opened their home for memorable graduate student dinners of veal and pasta, attended by all of her students. Those evenings, in the South Park neighborhood of Morgantown, remain some of my fondest memories of graduate life. Katherine, considering the rarity of scholars studying German Central Europe before the twentieth century in the United States, has truly been the solid foundation upon which this dissertation was built. I will be forever grateful for her support, and the gift of her time in difficult circumstances. She has been the best Doktormutter a Doktorand could hope for.

I sincerely appreciate the vast assistance given to me by the archivists archival staff across Europe and North America. Archivists helped me greately at the Society of the Cincinnati Library, National Archives of the United States, Library and Archives of Canada, British National Archives, Templer Study Centre, Kent Local History Centre, Geheimes Staatsarchiv Preußischer Kulturbesitz, Hessian State Archives in Wiesbaden, Darmstadt, and Marburg, and the Brandenburgisches Landeshauptarchiv. I received exemplary service at all of these fine institutions. Among the many archivists I have encountered in my travels, three stand out. At the Society of the Cincinnati Library, Director Ellen Clark has been a repository of knowledge 
regarding eighteenth-century warfare, and a constant help to my work since I was completing my MA degree in 2013. At the National Army Museum in Chelsea, Robert Fleming assisted my work for two years running, and kept me well supplied with documents in the most pleasant archival environment imaginable. Finally, Herr Michael Scholz at the Hessisches Staatsarchiv Darmstadt was extremely helpful, and even kindly retrieved document outside of the normal daily pull times: truly an extraordinary gesture.

Numerous historians kindly donated their time to read this dissertation, and their advice has considerably improved the final result. Sascha and Katrin Möbius gave extensive feedback on almost every aspect of my work, from explaining obscure nuances in Early Modern German, to assisting with my organizational knowledge of the Prussian Army. Dr. Möbius also kindly agreed to serve as my outside reader before scheduling conflicts made that impossible. Dr. Michael Leggiere, of the University of North Texas, brought his keen powers of writing and as well as the logical mind of a military historian, to bear on this manuscript. Rick Schneid, of High Point University, generously read several chapters and suggested improvements. Max Flomen, coming late to the project as a result of his recent appointment at West Virginia University, was kind enough to read and give suggestion on how to improve the work for an American audience. Finally, Dr. Matt Vester provided much needed help and relief throughout the process of writing this dissertation. He generously hosted meetings of the WVU History dissertation reading group at his home, where the pasta was pleasurable as the scholarly criticism was pointed. Dr. Vester also joined the project as Co-Chair. His wisdom and keen eye for early modern literature were able to point of some of the literary influences of eighteenth-century soldiers.

In addition to the wisdom directed from above, I have benefited from a great deal of assistance from my peers. Catherine Ferrari, Dr. Zac Cowsert, Dr. Chuck Welsko, Dr. Luke Gramith, and so many of my friends at West Virginia University facilitated my understanding of the past with sharp discussions in the G-13 office. Finally, and most importantly, my wife Noelle Harris has been a constant source of support. Patiently enduring my long archival trips overseas, as well my incessant rambling about Frederick's Prussia, Noelle gave extensively editorial support to my manuscript. I could not have completed this project without her love and help.

In April of 2019 my advisor, Katherine Aaslestad, was diagnosed with terminal cancer. After a lengthy struggle, she passed away in April 2021, just a month after my defense. In those two years, Katherine was a model of strength, endurance, and humanity. Her stahlhart spirit enabled her to continue working on projects for myself and other students until the very end. I will be forever grateful that she was able to attend my dissertation defense. She embraced life and fought cancer hard to remain with her family. The ways that this project is a success are in large part a tribute to her. Along with all of her students, I will never forget her kindness.

Morgantown, WV

2021 


\section{Introduction}

On the fifth floor of the Kreitzberg Library at Norwich University, in the Archival Reading Room, there is a book that reflects the approach of this dissertation. In 1757, John Rivington and James Fletcher, of Pater-Noster Row, together with their partners on CatherineStreet and Fleet Street, printed a translated manuscript, New Regulations for the Prussian Infantry. Increasingly from the 1740s, the general public and military officers sought out learned treatises on the profession of arms, and this book was an example of such a manuscript. At face value, it was a literal translation of the Prussian Reglement, or infantry manual, describing the process of training and readying common soldiers for modern warfare in the middle of the eighteenth century. Printed as Britain and Prussia stood as allies in the opening years of the Seven Years War, this book represented one of hundreds of books published for an educated reading public. This particular copy of the book, however, also includes notations made by a young junior officer, indicating a vibrant transnational military public sphere in Britain and Prussia. $^{1}$

Ensign Christopher Darby, a sixteen-year-old junior officer in the $33^{\text {rd }}$ Regiment of Foot, acquired this copy of the book sometime before his departure to fight in North America during the American War of Independence. During Darby's tenure in the British Army, the military was increasingly besotted with the idea that the emulation of a specific foreign state, Prussia, would lead to formulaic military success. In the spare pages of the book, Darby recorded notes from headquarters while in Halifax in 1784, and kept a journal of his North American experiences dated from 1775. He made marginal notations in the work, describing the differences in practice

\footnotetext{
${ }^{1}$ Norwich University Kreitzberg Library Special Collections, 356.10943 P972n "New Regulations for the Prussian Infantry, Signed Christopher Darby, January $9^{\text {th }}, 1784^{\text {" }}$
} 
between British infantrymen and their Prussian counterparts in the 1780s, and also made extensive notations regarding the way common soldiers were paid in the British Army. His marginal notations compared and contrasted British practice with Prussian standards, with regards to how officers could better regulate the movements of common soldiers. Darby had been influenced by a British military culture which recognized Prussian military efficiency and practices, and attempted to emulate it in Britain.

Darby's notations display the important connections between the British and Prussian military systems in the latter third of the eighteenth century. This young man was caught up in a military world which had become obsessed with reading, writing, innovation, and transnational comparisons. Both partisan contemporaries and historians have sometimes dismissed this type of evidence as the raving of a few infatuated "prussomaniac" officers of the German school. ${ }^{2}$ This dismissal deliberately ignores the deep connection between the military systems of Britain and Prussia between 1739 and 1789. During those years, Britons found much to admire in their distant Prussian cousins, and shared a great deal of common military experiences with them. This introduction explains the major themes of my dissertation, provides a brief summation of the military and political history of the two states under examination, explores the major historiographical frameworks to which the dissertation contributes, and provides a road map of how the dissertation will unfold.

\section{THESIS AND METHODOLOGY}

I argue that historians of eighteenth-century common soldiers can better challenge national myth-making by employing a transnational lens. My study focuses on the Kingdoms of

\footnotetext{
${ }^{2}$ Charles Cornwallis, Correspondence of Charles, first Marquis Cornwallis, (London: 1859), 1:212; John Ferling, Almost a Miracle: The American Victory in the War of Independence, (New York: Oxford University Press, 2007), 49-51; Christopher Duffy, Army of Frederick the Great, ${ }^{\text {st }}$ Edition, (London: Hippocrene Books, 1974), 210.
} 
Prussia and Great Britain, two states that already have rich national historiographies on eighteenth-century military affairs. Despite this, my research improves our understanding of the military development of both states between 1739 and 1789, by showing how both Prussian and British officers tapped into the experiences of common soldiers in order to improve military efficiency. Localism, kinship, and religious belief were crucial elements of the worldviews of eighteenth-century soldiers, and as the century progressed, officers instrumentalized that knowledge in order to reform their own forces. The evidence on which this argument is based is analyzed in chapters that take up four distinct themes: evidence of local connections in soldiers' writings, the world of violence that these soldiers experienced, the importance of religious sentiments in eighteenth-century armies, and officers' transnational and local military experiences.

Fundamentally, this dissertation compares and contrasts the military worlds of soldiers in Britain and Prussia during the eighteenth century. In order to do so, it explores the experiences and ideologies of common soldiers, the writings of officers in the military public sphere, and the transnational exchanges which occurred between these two states. Beginning with the journeys of military men between the two states, the dissertation follows this thread of inquiry to the world of common soldiers, whose letters display the importance of local connections in shaping soldiers' worlds, and show how soldiers in both states drew on religious convictions. My analysis demonstrates how both states utilized localism and local communities in recruiting and fostering connections between soldiers based in place of origin. Whereas these two states have often been viewed as opposites, this dissertation shows that they were both expanding militaryfiscal states whose military affairs were broadly similar, and increasingly so between 1739 and 1789. 
In order to explore the worlds of soldiers in these two states, I have collected an extensive body of letters written by common soldiers during this period. Out of the hundreds of thousands of soldiers serving in the British and Prussian Armies in the mid-eighteenth century, we have fewer than 200 letters. At first glance, this would seem to cast doubt on the representativeness of the evidentiary base. In soldiers' memoirs, however, one finds frequent references to soldiers writing letters home to their family, as part of normal experience in military life. Limited correspondence from soldiers does survive. Although state archives competently store material related to the state, personal letters between ordinary people are not necessarily related to the state. As such, surviving letters were often lost to posterity. They are only stored in rare circumstances: donated by a family member, recorded in court proceedings, lost in the mail and held, captured on enemy ships, etc. Likewise, most family members would not have kept letters for long periods of time, and if they did, plenty of time exists between 1789 and the present to account for the disposal of family-held letters due to water, rot, mold, etc. Finally, a reading of Harari's The Ultimate Experience reminds us that the popular view that soldiers' writings were intrinsically valuable was in its infancy during the eighteenth century. ${ }^{3}$ Whereas in the Napoleonic Era and afterwards, civilians would save the writing of soldiers as evidence of a transcendent experience, that idea was not fixed in the mid-eighteenth century. As a result, soldiers' letters did not take on the special character (especially among common people) that they would in the nineteenth century.

In addition to exploring the world of common soldiers and the community links identified in their letters, my dissertation also explores the larger military public sphere created by literate officers, and in particular their views on how the community-based world of common soldiers

\footnotetext{
${ }^{3}$ Yuval Noah Harari, The Ultimate Experience: Battlefield Revelations and the Making of Modern War Culture, (New York: Palgrave Macmillan, 2008) 160-298.
} 
could be used in military reforms. Between 1739 and 1789, most officers in Britain and Prussia did not receive formalized military training, but instead experienced what might be called on-thejob training. During this training, they supplemented their experiences by reading widely. They devoured texts ranging from ancient military history to geography to the drill manuals of other states to specialized treatises on gunnery and geometry. Following the path-breaking work of Ira Gruber in this field, this dissertation charts the scope of the military-literary public sphere: the process of officers travelling to other states, recording their observations, and publishing their findings. ${ }^{4}$ For example, as British officers increasingly found themselves drawn to the world of Frederick the Great, many British officers used their passing connection with that world in order to make a name for themselves, strengthen their own patronage networks, and demonstrate the importance of international developments to the recruitment, training, and combat effectiveness of the British army.

By choosing to evaluate soldiers in Britain and Prussia in the eighteenth century, this dissertation also contributes to debates regarding the development of these states during this period. Contemporary authors (and the historians who followed them) naturally characterized and stereotyped the nature of the British and Prussian states between 1739 and 1789, often claiming that these states were extreme examples of liberty and freedom or despotism and militarism. This dissertation, in line with recent research on the nature of these eighteenthcentury states, challenges the dominant scholarly assumption that these states were pure examples of either liberty or militarism, claiming instead that both were imperial military-fiscal states, determined to grow their own power, often at the expense of their neighbors. Furthermore, by examining soldiers and their home communities, this dissertation contributes to recent

\footnotetext{
${ }^{4}$ Ira D. Gruber, Books and the British Army in the Age of the American Revolution, (Chapel Hill: University of North Carolina Press, 2010).
} 
discussions regarding the development of a soldierly identity in Europe during the course of the eighteenth century. In Britain, for example, some British soldiers began to think of themselves collectively as distinct from civilians, whereas in Prussia, the nature of the canton system promoted the creation of a soldierly identity that was deeply connected to the civilian world on the part of Prussian cantonists. So, whereas across much of Europe throughout the eighteenth century, soldiers were becoming increasingly disconnected from civilian life, in Prussia, this process was slowed by the canton system.

This dissertation also examines claims about the nature of warfare and violence in Britain and Prussia during the eighteenth century. This period, often referred to as the Kabinettskriege era by an older generation of German scholarship, was previously understood as a time of limited conflict, which reduced the impact of warfare on civilian populations. For Siegfried Fiedler, the Kabinettskriege age was characterized by,

the strength of military discipline, the deliberate restriction of national passion, general concern for the state's economic stability, an honorable international military aristocracy, the principle of army conservation, the quick exchange of prisoners, the neutrality of noncombatants and the humanitarian tendencies of the enlightenment, which all came together in order to restrain the forces of war. ${ }^{5}$

Armies changed in these decades. Monarchs and their cabinet ministers regarded their armies, which were new professionalized after the end of the Wars of Religion, as too expensive to be wasted foolishly. Since the 1970s, historians have been increasingly challenging this view of limited warfare, not only in Europe, but also with regards to the American War of Independence. A focus on localized violence in the eighteenth century provides insights into the nature of warfare that both soldiers and civilians experienced, but it does not mean civilians experienced the horrors of war in the same way that they had endured the mass slaughter of the Thirty Years

\footnotetext{
${ }^{5}$ Siegfried Fiedler, Kriegswesen und Kriegführung im Zeitalter der Kabinettskriege (Koblenz: Bernard and Graefe, 1986) 21.
} 
War. Indeed, in terms of lethal violence against civilians, the eighteenth century did show a marked drop in mortality. Timothy Blanning, one of the leading eighteenth-century scholars, wrote this on the subject in his 2007 book, Pursuit of Glory:

So war had not lost its teeth. Yet taking a long view of the period 1648-1815, or at least 1648-1792, it can be seen that it did gradually lose some its destructive force. It was not that wars became less frequent: on the contrary, there was a major war between European powers in every decade of the eighteenth century except perhaps the 1720s. Rather, it was the case that armies were now better disciplined and better provisioned... one state after another moved to establish control over their armed forces. War was still a terrible affliction for anyone unfortunate to get in its way, but conflicts did become shorter in duration and more limited in geographical scope. It was Frederick the Great's declared ambition to isolate warfare from civilians to the extent that they would be unaware that it was underway. Of course, he failed, indeed, he himself claimed that the Seven Years War had been as catastrophic from a demographic point of view as the Thirty Years War. However, there was no return to the anarchy of the first half of the seventeenth century. ${ }^{6}$

This dissertation largely confirms Blanning's analysis. War caused suffering for rural and urban commoners wherever it was found in eighteenth-century Europe. The nature of war for civilians, as a result of logistical changes and professionalization, was radically different from the era of the Wars of Religion and that of Napoleon.

For soldiers in combat, warfare remained a visceral and terrifying experience in the age of the so-called "lace wars." Christopher Duffy, Sascha Möbius, Matthew Spring, and Ilya Berkovich have all demonstrated the ways in which the battlefield remained a physically deadly and psychologically damaging place of horrors. ${ }^{7}$ Soldiers saw their friends and relatives killed

\footnotetext{
${ }^{6}$ Timothy Blanning, The Pursuit of Glory: Five Revolutions that Made Modern Europe, 1648-1815, (London: Penguin, 2008), 56.

${ }^{7}$ Christopher Duffy, The Military Experience in the Age of Reason, (New York: Atheneum, 1988), Sascha Möbius, Mehr Angst vor dem Offizier als vor dem Feind, (Saarbrücken, VDM Verlag, 2007), Matthew Spring, With Zeal and With Bayonets Only,(Norman: University of Oklahoma Press, 2008), Ilya Berkovich "Fear Honour, and
} 
directly in front of them, experienced painful wounds, were left on the battlefield for hours and days as the armies continued their maneuvers, and had little chance of a full recovery from many types of wounds. If warfare for civilians in Britain and Prussia lessened in violence during this age, for soldiers, it remained an era of brutal battlefield violence. In addition to these themes, my dissertation also contributes to several larger debates in Prussian, British, and European historiography. For that reason, and to establish a clear context for my following chapters, I provide an overview of Britain and Prussia in the eighteenth century and several of the associated historiographical trends and discussions in their state histories to illustrate the importance and significance of a transnational study of these two largely Protestant kingdoms.

BRITAIN AND PRUSSIA AT WAR AND PEACE: 1739-1789

Between 1739 and 1789, the British and Prussian states waged intense conflicts of immense consequence for the modern world. The following paragraphs outline the chief military and political developments in these two states. The first of these major conflicts was the War of Austrian Succession (1739-1748). In 1739, Britain and Spain began armed conflict over trade and maritime rights. This conflict, often called the War of Jenkin's Ear, or more accurately, the War of the Asiento, was subsumed by the more general War of Austrian Succession after 1742. This conflict, which ended in 1748, saw fighting between almost all the major powers of Europe. In the imperial conflict outside of Europe, Britain and France maintained a rough parity, whereas in Europe, France and Prussia scored significant victories over Britain and Austria, as Bavaria and Saxony were reduced to the level of third-rate powers in the Holy Roman Empire. This war also saw the expansion of the Prussian state into Silesia, the failure of the Jacobite movement to 
supplant the Hanoverian dynasty in Britain, and the increasing movement of Frederick of Prussia towards the status of a pan-European celebrity.

The Diplomatic Revolution of 1756 radically transformed the coalitions that had formed during the War of Austrian Succession. France and Austria allied as a result of the diplomatic maneuvering of Austrian minister Kaunitz, joining forces against the newly powerful and expanded Prussian state. Prussia, surrounded by the hostile states of Austria, France, and Russia, sought out Britain as a potential ally, and benefitted from the continental interests of the Hanoverian dynasty of George II of Great Britain. During the resulting Seven Years War (17541763), Military hostilities began in North America with a twenty-two-year-old George Washington commanding the initial skirmish at Jumonville's Glen. Two years of inconclusive fighting followed, marked by the disastrous defeat of the British Army under General Braddock near Ft. Duquesne. Britain and France formally declared war in 1756, when hostilities began between the major powers of Central Europe. Despite initial setbacks, Britain was overwhelmingly successful in the wider imperial war, winning major victories in North America, the Caribbean, India, and the Philippines. In Central Europe, British-backed Germanic forces fought successfully against the French, as Frederick of Prussia floundered yet survived year after year of conflict against Austria and Russia. Frederick won the undying love of the British population for his victory over the French at Rossbach, and in the British press assumed the character of a noble figure fighting against impossible odds. In reality, Prussian success (if it can be called that) in Central Europe came from Frederick's dedicated and professional officer corps, and Prussia managed to survive the Seven Years War territorially intact, but economically and demographically damaged. 
The American War of Independence (1775-1783) followed an imperial crisis in Britain's North American colonies in the 1760s. The British Army failed to stop the rebellious American colonists, and was eventually drawn into a wider war against the French, Spanish, and Dutch. The failure to subdue the rebellious colonies generated a call for military reform. Concurrently, but politically unrelated, Prussia fought a brief war against Austria over which dynasty would control Bavaria in the Empire, usually referred to in English as the War of Bavarian Succession (1778-1779). This desultory conflict, colloquially known as the Kartoffelkrieg in German for the food grown by inactive soldiers, brought little military advantage to either side. After building a powerful coalition of his former enemies of Saxony and Russia, Frederick II scored a political victory over the matter of succession. German scholarship understood this war as one of the final Kabinettskriege of the Old Regime. These were the last major military conflicts waged by Britain and Prussia before the outbreak of the French Revolution in 1789. With the course of military history charted, I will now turn to key political and military figures during this period in the two states.

During almost all of the era under examination, Frederick II (r.1740-1786) was the ruling Hohenzollern monarch in Prussia. He assumed the throne after the death of his father, Frederick William I (r.1713-1740), and his reign ended just three years before the French Revolution. Thus, as ruler of one of the principal states being analyzed, and more importantly, a key figure in the military of that state, he will be encountered frequently in the chapters that follow. In Britain, the era is divided between two reigning monarchs: George II and George III of the Hanoverian dynasty. George II (r. 1727-1760) took an interest in military affairs, and was the last English monarch to lead an army on the battlefield. His son, William August, the Duke of Cumberland (1721-1765), played a pivotal role in the formation, organization, and performance of the British 
Army in the eighteenth century, and like Frederick II of Prussia, will be encountered frequently in this dissertation. In the military sphere during the 1740s and 1750s, the Duke of Cumberland became almost like a viceroy, with royal authority to make military administrative changes. ${ }^{8}$ Tragically for Cumberland, he was sidelined after his defeat at Hastenbeck and the Convention of Klosterzeven in 1757. George III (r. 1760-1820), the grandson of George II, played little direct role in military affairs but was initially advised on military matters by his uncle, the Duke of Cumberland.

Although both royal families had a large degree of influence within their militaries, the military structure of each of the two states requires some contextualization. The British military of the eighteenth century was largely recruited voluntarily by officers leading regimentally specific recruiting parties throughout Britain. Occasionally, the British military would supplement its forces by impressing unwilling men into service, or attempting to recruit large numbers of soldiers from outside Britain. Both of these tactics were used in the course of the American War of Independence, with impressed soldiers from inside Britain, and foreign recruits drawn from the Holy Roman Empire. Once men had been recruited into the army, they served with their regiments in a variety of capacities. During wartime, large bodies of troops would be brought together in order to defend Britain from invasion and conduct expeditions to invade enemy territory or safeguard distant allies. In peacetime, smaller groups of soldiers, sometimes at the company level, would be disturbed throughout Britain, conducting various public projects, such as the construction of roads in rural areas, and taking action against smugglers who attempted to land on the coasts of Britain.

\footnotetext{
${ }^{8}$ TNA WO $7 / 25$ f. 123 . This document gives the Duke equal authority with the king in the arena of military equipage.
} 
By contrast, the Prussian military was composed of two different bodies of soldiers: soldiers from inside Prussian borders recruited compulsorily via the canton system, and those recruited voluntarily from both inside and outside Prussia. Each regiment was assigned a particular district or districts from which to draw native recruits; likewise, each regiment had recruiting parties spread across the Holy Roman Empire to tap foreign manpower. It is important to note that though some recruiting parties enlisted men voluntarily, some men were also tricked into serving against their will, or signed up based upon false promises. During wartime, the army could be quickly assembled into various bodies for offensive and defensive operations. In peacetime, however, the Prussian army looked quite different from most European armies. Native cantonists trained with their regiments for two or three months out of the year, and then were furloughed home, almost like reservists in a modern military sense. Likewise, foreign soldiers, despite remaining assembled with their regiments, were free to pursue trades as urban Freiwachter, or licensed civilian laborers, for four days out of the week. The Prussian army, though compulsorily recruited, retained significant ties to the civilian world, which the British military did not similarly possess. With the broad outlines of the military history of the era discussed, this introduction will now chart the ways in which historians have previously compared these two military states, and how their interpretations have shifted.

\section{BRITAIN AND PRUSSIA: STEREOTYPES AND NATIONAL HISTORIOGRAPHY}

The standard Anglophone story of the modern world tells a distinct story that highlights radical differences in the nature of state-building and war in the history of Germany and the United Kingdom. In this traditional history, Britain's parliamentary representative form of government epitomized the development of what is called "western democracy" in the twenty- 
first century. ${ }^{9}$ This same view of history associates Prussia, by contrast, with repression, militarism, and a rule by despotic military elite. ${ }^{10}$ By the latter third of the twentieth century, in light of the horrors of the century's wars, Anglophone historians portrayed Prussia as the archtypical military state, to such an extent that all military states were filtered through the lens of Prussia. In their 1971 survey of history to 1648, Paul Bernstein and Robert Green described the ancient Assyrian state: “The Assyrian army was the key institution. Its Prussian-like efficiency made it the terror of the Near East."11 The adjective Prussian took on a descriptive and pejorative tone in Anglophone historiography.

This type of diametrical thinking has continued into more recent scholarship. In the second volume of his history of the Royal Navy, N.A.M. Rodger, the doyen of Maritime History, decried the fact that historians had written a book in which "Britain is treated as a military power directly comparable to Prussia. None of the distinguished contributors to the book seem to be aware that Britain's contribution to warfare, and warfare's contribution to British history, were rather unlike those of Prussia." ${ }^{12}$ The book he criticized, Rethinking Leviathan: The EighteenthCentury State in Britain and Germany, asks many of the questions that lay the groundwork for this dissertation. ${ }^{13}$ John Childs, a landmark name in the military historiography of eighteenthcentury Europe, penned the chapter comparing military systems in Britain and Prussia during the eighteenth century. He concludes:

\footnotetext{
${ }^{9}$ Thomas Babington Macaulay, The History of England from the Accession of James the Second, (London: 1848).

${ }^{10}$ Winston Churchill, A History of the English Speaking Peoples: The Age of Revolution, (London: Cassell, 1956) 3:104.

${ }^{11}$ Paul Bernstein and Robert Green, History of Civilization, Volume I: to 1648, (New York: Littlefield Adams, 1976) 24.

12 Nicholas A. M. Rodger, Command of the Oceans: A Naval History of Britain, 1649-1815, (London, W.W. Norton, 2005), lxiii.

${ }^{13}$ Rethinking Leviathan: The Eighteenth-Century State in Britain and Germany, ed. John Brewer and Eckhart Hellmuth (Oxford: Oxford University Press, 1999).
} 
Eighteenth-century Britain was geared for war but it was not a militarized state. It was militarily powerful, both by land and sea, but the state and society did not adopt an organization based around the needs of the military as happened in Prussia after 1733 and Hesse-Kassel after 1762. To a large extent, the British Army stood outside and beyond existing political and social institutions rather than experiencing a Germanic integration. Recruitment was voluntary in both the army and the navy, despite the existence of the press gang, and there was never any suggestion that conscription with all its administrative paraphernalia of registration of births and cantons might be introduced. $^{14}$

As this dissertation will show, Childs was incorrect. ${ }^{15}$ Key figures in the British monarchy and military structure did indeed suggest that Britain adopt a cantonal system of conscription in the middle of the eighteenth century. In the final accounting, to accomplish military reform conscription was avoided, but the British Army did indeed begin the process of adopting a localized and voluntary cantonal system after 1782 . This dissertation recognizes that Britain and Prussia were socially, economically, and politically different. Yet, in the world of Prussian and British military affairs, much united the experience of common soldiers. This dissertation will confirm what Mark Wishon has briefly argued, that contemporary officers found much to observe, admire, and adopt as they also criticized and stereotyped their respective "national character" and military systems. ${ }^{16}$ The British and Prussian armies of the eighteenth century were distant cousins with shared and distinct components, but in experiential and organizational terms, they remained mutually intelligible and sometimes interchangeable. This fact has important developmental implications for the broader historiography of the modern world, and shatters the traditional bi-polar, deterministic view of modern history according to which Britons were on a

\footnotetext{
${ }^{14}$ John Childs, "The Army and the State in Eighteenth-Century Britain and Germany," in Rethinking Leviathan: The Eighteenth-Century State in Britain and Germany, eds. John Brewer and Eckhart Hellmut (Oxford: Oxford University Press, 1999), 68.

${ }^{15}$ See chapter seven for evidence that British military commanders strongly considered this possibility.

${ }^{16}$ Mark Wishon, German Forces and the British Army: Interactions and Perceptions, 1742-1815, (London: Palgrave Macmillan, 2013), 19-41.
} 
straight road to democratic progress, and Prussians on a straight road to benighted militarism. Rather, during the eighteenth-century infancy of the modern world, the developmental path of these two systems was neither constructed nor determined. Their twentieth-century outcomes were not fore-ordained.

\section{FREDERICK II AND PRUSSIAN MILITARISM}

In his 2011 work on the material culture of the Prussian Army, Daniel Hohrath summarized the historiography on Prussia, Frederick the Great, and the Prussian Army as follows:

In early histories, Prussia's rise appears as a slow but purposeful process leading to its development as Europe's primary great power of the nineteenth century. Interestingly, the ideas of the "friends of Prussia," who have idealized the creation of this powerful military state that was later to establish the united German Empire, and those of the "enemies of Prussia", who primarily see the century-long process of militarization that led to the catastrophe that was to engulf Germany and Europe as an expression of the Kingdom's "exceptional path", (Sonderweg) apparently only differ in their morale assessment of the situation; both are searching for the principles and preconditions that seem to be present in the early situation of the domain of Brandenburg-Prussia. ${ }^{17}$

This paragraph perfectly encapsulates the major debates in the field regarding Frederick, Prussia, and the development of militarism in that state. For much of the nineteenth and twentieth centuries, Frederick and the Prussian system was worshipped by a series of military and political historians who sought to praise his military, political, cultural, and artistic accomplishments. Already prior to the Second World War and all the calamities that it entailed, historians have been much less sanguine about the legacy of Frederick II. Generations of historians sought to explain "what went wrong” in German Central Europe, particularly in Prussia.

\footnotetext{
${ }^{17}$ Daniel Hohrath, "The Development of the Old Prussian Army," in The Uniforms of the Prussian Army under Frederick the Great ed. Daniel Hohrath (Berlin: Militaria Verlag, 2011), 14.
} 
Since the reunification of German in 1990, both English- and German-speaking historians have balanced their critiques of Frederick and his kingdom. A synthesis, or at least a balance, has been reached by most scholars who understand that the Prussian Kingdom under Frederick was both authoritarian and enlightened. On the two-hundredth anniversary of the king's death and three-hundredth anniversary of his birth, biographers appeared with largely balanced works pointing to the king's human complexity. Frederick himself played a role in the development of this historiographical tradition, as Christopher Clark has importantly noted, but Clark also points us to the idea that "the anecdotes of Frederician memory... offered unique moments suspended in time that resisted integration into the grand narrative of history." ${ }^{18}$ Clark reminds us: "No one who insisted so vehemently on his own uniqueness could wish to be embedded in the interdependencies of 'history.' Frederick prized the past above all as a storehouse of shining exemplars that spoke to and resonated with his own achievements." ${ }^{, 19}$ Unsurprisingly, perhaps, the early historians of the king viewed him very much in this way: like a classical hero come to life.

The beginnings of independent historical inquiry into the period of Frederick the Great begins in the nineteenth century, with the nine-volume history of Johann David Erdmann Preuss, published from 1832-1834. ${ }^{20}$ Born in 1785 in Prussia, during the final years of Frederick's life, Preuss wrote a narrative history with supporting documents, which was revised once during his life, in response to the increasing standardization of historical professionalism during the midnineteenth century. Preuss opened a series of debates regarding the nature of the king's reign, principally regarding whether or not he should be considered a progressive or conservative ruler.

\footnotetext{
${ }^{18}$ Christopher Clark, Time and Power: Visions of History in German Politics, from the Thirty Years War to the Third Reich, (Princeton: Princeton University Press, 2019) 112.

${ }^{19}$ Ibid, 113.

${ }^{20}$ Johann D. E. Preuss, Urkundenbuch zu der Lebensgeschichte Friedrichs des Großen (Berlin: Nauck, 1832-1834).
} 
As a result of this biography, Preuss began the first major edition of Frederick the Great's papers, with the blessing of the current reigning Prussian king, Frederick William IV. The Scottish writer and proponent of the "Great Man" theory of history, Thomas Carlyle, wrote an extensive history of the Prussian king in 1858 that has been largely dismissed by twentieth-century professional historians as an unprofitable exercise in hero-worship. ${ }^{21}$

Johann Gustav Droysen, born into a Prussia reshaped by the Napoleonic Wars, began to develop a larger historical narrative regarding the role and mission of Prussia. Far from viewing Prussian military efficiency with suspicion, Droysen believed that the American Revolution, French Revolution, and Prussian Uprising against Napoleon were all movements of liberation driven by the same force. ${ }^{22}$ Droysen gave voice to the belief that the Hohenzollern dynasty had possessed a longstanding special destiny in German Central Europe. Droysen became a fixed star in the "Prussian School," taught at Kiel, Jena, and finally Berlin, and influenced many of the historians of the later nineteenth century, such as Reinhold Koser. In his later life, Droysen turned to writing a political history of the Prussian state under Frederick II, but only reached the start of the Seven Years War by the time of his death. Reinhold Koser continued Droysen's task of writing the political history of Frederick II, completing a four volume biography of the king which is still cited by German historians. ${ }^{23} \mathrm{He}$ focused on military affairs and political accomplishments, not Frederician culture. Importantly, Koser founded a journal dedicated to the study of Prussian history, the Forschungen zur Brandenburgischen und Preußischen Geschichte in 1888, and he remained its chief editor until his death in 1914. The reason why Koser stands foremost among the ranks of nineteenth-century Frederician historians, however, is his

\footnotetext{
${ }^{21}$ Thomas Carlyle, History Friedrich II of Prussia, Called Frederick the Great (London: Estes and Lauriat, 1858).

${ }^{22}$ George P. Gooch, History and Historians in the Nineteenth Century, (London: Longman, 1913) 135.

${ }^{23}$ Reinhold Koser, Geschichte Friedrich des Großen (Stuttgart \& Berlin: J.G. Cotta, 1921).
} 
publication of the twenty-eight volume set of Frederick's Politische Korrespondenz. This body of literature remains the definitive published primary source for historians working on the king.

Other historians working in the same era sharpened their understanding of the military aspects of his reign. Theodor von Bernhardi ‘s 1881 study, Friedrich der Grosse als Feldherr argued that Frederick was militarily advanced in his thinking, and that Frederick's way of war pointed to the key developments of Napoleonic warfare: rapid movement of large forces, and a willingness to engage the enemy on the battlefield. ${ }^{24}$ Prussian military historian Hans Delbrück challenged this interpretation to assert that Frederick's way of war was not rapid or particularly aggressive, but that it confirmed largely to the patterns of his time. ${ }^{25}$ This debate continued from the 1890s into the 1920s, and shaped the careers of a generation of military historians working on Frederick II, such as Rudolf Keibel and Max Lehmann.

The Nazi era provided another watershed in the scholarly examination of Frederick II. National Socialist historians cultivated continuity between their regime and high points of German history, and chose Frederick II as their symbol. These historians published many poor biographies of Frederick (Wilhelm Wolflast's bombastic, Die Kriege Friedrichs des Grossen is a prime example of this tread), but conservative historian Gerhard Ritter's work stands out for its excellence when compared with the rest. Ritter, an authoritarian conservative but not a Nazi, published his biography of Frederick the Great in 1936, three years after the Nazi creation of a one-party state. Ritter defended Frederick from association with the National Socialists in two works: first, his short monograph on the continuities of German History: Europa und die Deutsche Frage, and second, in his magisterial four volume study: Staatskunst und

\footnotetext{
${ }^{24}$ Theodor von Bernhardi, Friedrich der Grosse als Feldherr (Berlin: E.S. Mittler und Sohn, 1881).

${ }^{25}$ Hans Delbrück, Die Strategie des Perikles erläutert durch die Strategie Friedrichs des Grossen: Mit einem Anhang über Thucydides und Kleon, (Berlin: Georg Reimer Verlag. 1890).
} 
Kriegshandwerk: das Problem des "Militarismus" in Deutschland. ${ }^{26}$ In these works, he argued that the development of National Socialism was a product of mass political movements, not associated with the military legacy of Frederick the Great. Ritter gained great notoriety in Germany as a result of his historical battles with Fritz Fischer, who attempted to prove the opposite thesis: that there was clear continuity between the German past with Prussia's leadership, and the National Socialist movement. ${ }^{27}$

Following the disaster of the Second World War, most historians agreed with Fischer's position: that developmental deficiencies defined German politics from other nations in Western Europe, and that these fundamentally authoritarian tendencies caused the Nazi Regime. The search for Prussia's, and by extension Germany's, special path (Sonderweg) led historians to search for differences in Prussian societal development, compared with the other states of the eighteenth century. This theory of a separate developmental path for Prussia possesses a rich historiographical tradition in its own right. ${ }^{28}$ Broadly, the Sonderweg had positive connotations in the nineteenth century, when it was used as a term to explain Prussia's rise to power from the time of the Great Elector to the unification of Germany. By the middle of the twentieth century, Sonderweg had taken on an overwhelmingly negative meaning, a catch-all term which tried to explain what had societally "gone wrong" with the development of Germany.

\footnotetext{
${ }^{26}$ Gerhard Ritter, Europa und die Deutsche Frage (München: F. Bruckmann Verlag, 1948); Gerhard Ritter, Staatskunst und Kriegshandwerk: Das Problem des "Militarismus" in Deutschland, (München: Oldenbourg, 1970). ${ }^{27}$ Annika Mombauer, "Introduction: The Fischer Controversy 50 Years On," Journal of Contemporary History 48, no. 2 (2013), 232.

${ }^{28}$ Dieter Groh, "Le « Sonderweg » de L'histoire allemande : mythe ou réalité ?," Annales. Histoire, Sciences Sociales 38, no. 5 (1983): 1166-87; David Blackbourn and Geoff Eley, The Peculiarities of German History: Bourgeois Society and Politics in Nineteenth-century Germany (Oxford: Oxford University Press, 1984); J. Kocka, "German History before Hitler: The Debate about the German Sonderweg," Journal of Contemporary History 23, no. 1 (1988);William W. Hagen, "Descent of the Sonderweg: Hans Rosenberg's History of Old-Regime Prussia," Central European History 24, no. 01 (1991): 24-50; Jurgen Kocka, "Asymmetrical Historical Comparison: The Case of the German Sonderweg," History and Theory 38, no. 1 (1999): 40-50.
} 
With relevance to eighteenth-century Prussia, this led to works such as Otto Büsch's famous, Militärsystem und Sozialleben im alten Preussen, 1713-1807: Die Anfänge der sozialen Militarisierung der preussisch-deutschen Gesellschaft. In this thorough work of social history, Büsch makes a concrete argument that the Hohenzollern monarchy's use of the canton system for recruiting soldiers fostered a unique developmental path for the Prussian state. For Büsch, the prominence of the Prussian monarchy and military "made difficult the development of a bourgeois self-consciousness on Prusso-German soil." ${ }^{29}$ Instead, the lack of bourgeois development allowed for the social-militarization of Prussia. It follows, then, that the seeds of German twentieth-century destruction were sown by Prussian hands in the eighteenth century.

The historians of the postwar West German Bielefeld School, who used quantification to explore social and political history, broadly followed this interpretation into the nineteenth century, led by Hans-Ulrich Wehler. Wehler argued that while the bourgeois had triumphed in the "normal" states of Britain and France, but in Germany, "a singular tension between tradition and modernity" had endured. ${ }^{30}$ Importantly, Wehler and the Bielefeld school placed most of the emphasis on the nineteenth century, in some cases beginning in 1848 , in others the focus remained on the economic development of the 1860s and onward. Focusing primarily on the power wielded by the Junker class in the Old Regime, these historians largely confirmed Büsch's analysis, even as they slightly changed the focus. David Blackbourn and Geoff Eley provided a substantial challenge to these Bielefeld School historians, and the idea of a special German developmental path broadly. ${ }^{31}$ In their view, the basic assumption of German historiography, that

\footnotetext{
${ }^{29}$ Otto Büsch, Militärsystem und Sozialleben im alten Preußen: 1713-1807: Die Anfänge der Sozialen Militarisierung der Preußisch-deutschen Gesellschaft (Berlin: De Gruyter, 1962), 118

${ }^{30}$ Hans-Ulrich Wehler, Preussen ist wieder chic.... Politik und Polemik in Zwanzig Essays, (Suhrkamp, 1983$), 33$.

${ }^{31}$ David Blackbourn and Geoff Eley, The Peculiarities of German History: Bourgeois Society and Politics in Nineteenth-Century Germany (Oxford, Oxford University Press, 1984).
} 
German history remained different and distinct from that of Western Europe, was unfounded. These scholars believed, in essence, that if their evidence was convincing, it would redirect "primary attention away from deeper historical continuities and towards the immediate fascismproducing conjunctures. ${ }^{32}$ Presenting arguments for the strength of bourgeois society, free press, and trade unions in German society in the late nineteenth century, Blackbourn and Eley conclude their volume with a reminder that "the distinctiveness of German history is probably best recognized if we do not see it (before 1945) as a permanent falling-away from the "normal.",33 Obviously, historians from the Bielefeld School, such as Jürgen Kocka, did not see these criticisms of the Sonderweg as totally convincing, but on the whole, a younger generation of historians has modified the strength of the Sonderweg thesis as a result. ${ }^{34}$

With a specific focus on Prussia, two recent books, one focusing on rural life, and one focusing on urban life, have challenged the basis of the Sonderweg thesis in the eighteenth century. S.A. Eddie's 2013 work, Freedom's Price, has demonstrated that the traditional story of the Prussian manorial economy is no longer tenable, and that serfdom in Prussia gave peasants access to capital which they used for their own empowerment. Eddie's claim, that the traditional story, "with its striking shades of light and darkness, of good and evil, has seemed cathartic for German historians, but in fact left large parts of the picture wreathed in obscurity," is taken up in an urban environment by Florian Schui. ${ }^{35}$ Schui's 2013 study, Rebellious Prussians, explores urban resistance to monarchs in late eighteenth century Prussia, finding that "an examination of the authoritarian tendencies in the Prussian public is useful and important, but it sheds light only

\footnotetext{
${ }^{32}$ Ibid, 50.

${ }^{33}$ Ibid, 291.

${ }^{34}$ Jurgen Kocka, "German History before Hitler: The Debate about the German Sonderweg," Journal of Contemporary History 23, no. 1 (1988): 3-16.

${ }^{35}$ S.A. Eddie, Freedom's Price: Serfdom, Subjection and Reform in Prussia, 1648-1848 (Oxford, Oxford University Press, 2013), 329.
} 
on a part of the historical reality." ${ }^{36}$ Instead, Schui asserts that "Prussian burghers challenged the authority of the state and sought to impose themselves politically in defense of individual freedom. ${ }^{37}$ Scholars writing in the second decade of the twenty-first century, then, appear to be exploring the ways in which peasants and burghers constructed their own worlds in eighteenthcentury Prussia, rather than viewing Prussian society as fundamentally oppressive and militaristic.

In the recent scholarship on Frederick II, there is one marked departure from this trend. Franz Szabo, author of the most recent survey of the Seven Years' War in Europe, argued that Frederick was a brutish dictator who prefigured Hitler. ${ }^{38}$ His book, The Seven Years' War in Europe, portrays the Seven Years War through the lens of the twentieth century, and he begins his story in the Führer bunker in 1945. Szabo fails to understand the eighteenth century on its own terms, and when discussing Frederick II of Prussia. even promotes Joseph Goebbels' idea that Hitler "lacked the utter and complete ruthlessness of Frederick. ${ }^{39}$ Szabo argues vehemently that the Seven Years War, often proffered as the most famous Kabinettskrieg, was nothing of the kind. He dismisses the idea that the Seven Years War, and perhaps by extension, other mideighteenth century conflicts, was "'civilized' or 'limited."'40 Szabo remains a fairly isolated example, as most historians, even those more apt to criticize Frederick, still argue he played a vital role in the outcome of the Seven Years War.

\footnotetext{
${ }^{36}$ Florian Schui, Rebellious Prussians: Urban Political Culture under Frederick the Great and his Successors, (Oxford, Oxford University Press, 2013), 197.

${ }^{37}$ Ibid, 197.

${ }^{38}$ Franz A. J. Szabo, The Seven Years War in Europe: 1756-1763(Harlow: Longman/Pearson, 2008), 21.

${ }^{39}$ Szabo, The Seven Years' War, $\mathrm{x}$.

${ }^{40}$ Ibid, 434.; The most recent English language literature review on the Seven Years' War remains: Hamish Scott, "The Seven Years War and Europe's Ancien Regime," War in History Vol. 18, no. 4 (2011) 419-455.
} 
Jürgen Luh's 2011 biography of Frederick II, (published just in time for the three hundredth anniversary of the king's birth) does not follow the traditional format of historical biography. Rather, Luh analyzes the king in four chapters: Pursuit of Glory, Tenacity, Stubbornness, and Reason. Luh's Frederick, above all, desires glory and fame, and an erasure of past embarrassment. Luh's contribution to historiography is to center Frederick's ego in the narrative of eighteenth-century Prussia. Luh presents a figure that is a master of selfrepresentation, and often uses good publicity to gain personal fame. There are times when Luh's Frederick seems to reflect Szabo's views. For example, Luh covers Frederick's harsh treatment of his brother, August Wilhelm, in great detail. Luh shows that Frederick was a master of shifting blame on those around him. When Frederick's orders had caused confusion and a strategic misstep, Frederick relieved August Wilhelm from command and sent him home in disgrace, in order to save his own reputation. Despite these very real character flaws, Luh also points to Frederick's authentic military abilities. Luh acknowledges that in the victories at Rossbach and Leuthen, at Liegnitz and Torgau, and Burkersdorf were "the result of Frederick's hope and work. ${ }^{, 1}$ Luh shows that Frederick achieved the fame that he desired, but at great cost personally, and to Prussia as a state.

Timothy Blanning recently offered a more traditional biography, featuring Frederick's military abilities prominently and entitling one chapter "The Seven Years' War: Why Frederick Won." He offers powerful reasons why Frederick was responsible for Prussian victory in the Seven Years War. Blanning concurs with the positive image of Prussian common soldiers provided by Bleckwenn, and argues that they were a vital ingredient in Frederick's success. Blanning also points to the Spartan nature of the king's lifestyle with his army, suggesting that

\footnotetext{
${ }^{41}$ Ibid, 76.
} 
his example may have inspired loyalty in his soldiers. Blanning calls the idea that the Prussian state survived the Seven Years War as a result of luck a "facile assumption. ${ }^{42}$ Blanning asserts that Frederick made colossal mistakes on the battlefield but survived as a result of his officers. He concludes that Frederick's greatest contribution to his own success was "his indomitable will and ruthless determination to keep going, no matter how desperate the situation looked. In short, he was an indifferent general but a brilliant warlord." ${ }^{43}$ Blanning ends his biography with the reminder that Frederick's legacy has been incredibly divisive, and the king can "claim to be the most controversial figure in German history, much more so than Adolf Hitler." ${ }^{44}$

The historiography of Prussia and Frederick the Great has endured several revolutions in thinking. These changes are almost always associated with current political events, such as the unification of Germany, the outbreak of World War One, the rise of National Socialism and the Second World War, and finally, the reunification of Germany. The historiography on Frederick II, then, undoubtedly follows the thread of current events and contemporary history. Both Anglophone and Germanophone historians seem to have reached an uneasy truce with the Prussian monarch, and though they amply expose his flaws, they find much to admire as well. This uneasy truce is also present in the literature on militarization in Prussia. Over eighty years on from the outbreak of World War Two, the narratives of Prussian militarism do not seem as clear as they were in the 1950s and 1960s. Generations of younger historians increasingly find the roots of militarization in the nineteenth century, rather than the eighteenth century. Indeed, much recent scholarship points to the complexities of life and freedoms enjoyed by subjects in eighteenth-century Prussia. While some interpretations still find Prussia's military state

\footnotetext{
${ }^{42}$ Tim Blanning, Frederick the Great: King of Prussia (New York: Random House, 2016), 301.

${ }^{43}$ Ibid, 303.

${ }^{44}$ Ibid, 615.
} 
problematic, fewer and fewer historians seem to draw a straight path between Frederick's Prussia and Hitler's Greater Germany.

\section{ENGLISH LIBERTIES AND EMPIRE}

The debates regarding the rights of freeborn Englishmen and their role in creating the British Empire are no less contentious than the argument over the role of eighteenth-century Prussia in fostering a uniquely German Sonderweg. Generations of scholars have sought to understand the role of British Empire in the world, and after the decline of Whiggish history which celebrated the spread of Anglo-Saxon culture and political institutions across the globe, historians have increasingly questioned the benevolent nature of the British Empire, showing that it was gained by violence, and maintained through an oppressive and impressive network of cultural hegemony. ${ }^{45}$ For much of the nineteenth and twentieth centuries, Anglophone scholars emphasized the rise of representative government beginning with the Magna Carta and moving into debates regarding a standing army and a limitation of monarchical power. Furthermore scholars point to growing commercial wealth and a firm rule of law as signs that the British people, unlike continental monarchies, had followed a more enlightened developmental path. ${ }^{46}$

It is indisputable that the British possessed a more representative form of government in the eighteenth century when compared to the continental monarchies such as France and Prussia. British politicians fiercely debated the role of a standing army, radical Whigs such as John Trenchard, who would later inspire the American Revolutionary Whigs, wrote (originally in 1698 , reprinted in 1751), "I will venture to say that if this army does not make us slaves, we are

\footnotetext{
${ }^{45}$ P.J. Marshall, The Making and Unmaking of Empires: Britain, India, and America, c.1750-1783 (Oxford, Oxford University Press, 2005). Thomas Metcalf, Ideologies of the Raj, (Cambridge, Cambridge University Press 1995). For information on relative rates of taxation in Britain and France, see Fiscal Crises, Liberty, and Representative Government 1450-1789, ed. Philip Hoffman and Kathryn Norberg (Stanford: Stanford University Press, 1994).

${ }^{46}$ Paul Langford, A Polite and Commercial People, (Oxford: Oxford University Press, 1992).
} 
the only people upon earth in such circumstances that ever escaped it." ${ }^{, 47}$ Hannah Smith has extensively examined the political debate over a standing army in Britain in the early eighteenth century, and throughout the century, the British people expressed a severe distrust towards their professional fighting forces as a threat to liberty. ${ }^{48}$ Linda Colley has suggested that militarized opposition to Catholic, Continental, Frenchness formed a large part of British identity in the eighteenth century, and Kathleen Wilson has demonstrated that only after the French entry in the wider American War for Independence did ordinary Britons begin to support martial figures such as Admiral Augustus Keppel. ${ }^{49}$ As P.J. Marshall has demonstrated, the American Revolution occurred, in part, as a result of the changing nature of the British Empire and the liberties of Englishmen after the Seven Years War. ${ }^{50}$ Regardless, Britons did not mind a standing army when it suited them. George Washington, writing to Americans who had bought into a particularly virulent strain of anti-standing army rhetoric, had this to say in December of 1776: "The Jealousies of a standing Army, and the Evils to be apprehended from one, are remote; and in my judgment, situated \& circumstanced as we are, not at all to be dreaded; but the consequence of wanting one, according to my Ideas." ${ }^{, 51}$ Washington's sentiments proved true throughout the eighteenth century in Britain: the only thing worse than having a standing army was being defenseless in the face of a powerful Bourbon monarchy. Thus, the British utilized naval power

\footnotetext{
${ }^{47}$ John Trenchard and Thomas Gordon, A Collection of Tracts by the Late John Trenchard... (London: Cogan, 1751) 98.

${ }^{48}$ Hannah Smith, "Politics, Patriotism, and Gender: The Standing Army Debate on the English Stage", Journal of British Studies, Vol. 50, (2011) 48-75; Hannah Smith, "The Army, Provincial Urban Communities, and Loyalist Cultures in England, Journal of Early Modern History, Vol. 15, (2011): 139-58.

${ }^{49}$ Linda Colley, Britons, Kathleen Wilson, The Sense of the People: Politics, Culture, and Imperialism in England, 1715-1785.

${ }^{50}$ P.J. Marshall, The Making and Unmaking of Empires, 273-352.

${ }^{51}$ George Washington, The Papers of George Washington, Revolutionary War Series, Vol. 6, 13 August 1776-20 October 1776, eds. Philander D. Chase and Frank E. Grizzard, Jr. (Charlottesville: University Press of Virginia, 1994), 393-401.
} 
in conjunction with a professional force by eighteenth-century standards, both at home and around the world in their colonial holdings.

Indeed, when turning to colonial policies, recent historians have challenged the standard story of Whiggish progress. Christopher Bayly argued that the late eighteenth century "represented not simply a hiatus between the irresistible waves of liberal reform, but a series of attempts to establish overseas despotisms which mirrored in many ways the politics of ...absolutism[..",52 Bayly argued that "these colonial despotisms were characterized by a form of aristocratic military government supporting a viceregal autocracy." ${ }^{, 53}$ Far from spreading liberty, according to this new formulation, the British Empire spread authoritarian rule as it generated an ethos of deserving governance at home. In the mid-eighteenth century, this type of authoritarian rule is developing a rich historiography of its own.

Between 1755 and 1764, some policy makers within British government pursued a project of expelling Acadians from Nova Scotia. In all, the British Army removed over 10,000 of these French speakers from their homes in Nova Scotia. In examining the Acadian expulsion, historians working in the eighteenth century confirm Bayly's argument. Geoffrey Plank writes, "the Acadian removal belongs to a particular moment in the evolution of British imperial policy...some policy makers came to believe that some of the culturally distinct communities residing within the nominal boundaries of the empire were inherently subversive." Plank notes further that "the proponents of these projects imagined that they could create a society of

\footnotetext{
${ }^{52}$ C.A. Bayly, Imperial Meridian: The British Empire and the World, (London: Routledge, 1989), 8. ${ }^{53}$ Ibid.
} 
increasingly undifferentiated colonists who would be industrious, Protestant, and Englishspeaking." 54

Historians have long debated whether Ireland formed a "laboratory of empire" and an early example of British repressive rule. ${ }^{55}$ In the era examined by this dissertation, however, Ireland was relatively peaceful, although heavily militarized by the presence of the Royal Irish Establishment of the British Army, and a series of modernized fortifications. The French brought violence to Ireland in 1760 when French forces landed at Carrickfergus, but otherwise, Ireland remained quiet. The mass violence of the Society of United Irishmen revolt would not occur until 1798.

If Ireland was occupied but peaceable during the 1739-1789 period, Scotland saw an intense outbreak of violence during the 1740s. The authoritarian violence of the English empire was deployed close to home in the eighteenth century, during the suppression of the last great Jacobite Rebellion in 1745-1746. Faced with Scottish intransigence after thirty years of Hanoverian rule, the government of George II deployed a massive military force to the Highlands. Jacobite historians continue to debate the legacy of the military policies of George II and his son, William August, the Duke of Cumberland. Much like the "friends of Prussia" and the "enemies of Prussia" described by Daniel Hohrath, historians can still observe a partisan divide in the writings of historians regarding the prosecution of the war against the Jacobite Rebellion. This divide can, of course, clearly be observed in the writings of historians, and reviews of other historians' work. In the autumn of 2020, The Scottish Historical Review

\footnotetext{
${ }^{54}$ Geoffrey Plank, An Unsettled Conquest: The British Campaign Against the Peoples of Acadia (Philadelphia, University of Pennsylvania Press, 2003), 160-61.

${ }^{55}$ Jane Ohlmeyer, “A Laboratory for Empire? Early Modern Ireland and English Imperialism.," in Ireland and the British Empire ed Kevin Kenny, (New York: Oxford University Press, 2006).
} 
published Darren Layne's review of Alastair Massie and Jonathan Oates' The Duke of Cumberlands Campaigns in Britain and the Low Countries, 1745-1748: A Selection of His Letters. Layne accused Massie and Oates of putting forward an apology for the Duke in their introduction and uses approximately 700 words of his 1000-word review to launch a rebuttal to their interpretation of Cumberland's character, and indeed, a referendum on the eighteenthcentury British imperial policies as a whole. ${ }^{56}$

Across the British Isles, in England, Ireland, and Scotland, troops were used to provide armed repression against working-class rioters repeatedly throughout the eighteenth century. From the repression of Cornish tin workers, to the Porteous Riots in Edinburgh, to the Gordon Riots in London, the British army worked industriously as an element of repression at home. Rural and urban riots plagued England from the 1750s to the 1780s, and almost invariably, the government called on the War Office to use military force in responding to these internal disturbances. 57

That historians are increasingly drawing attention to the repressive use of force by the British government indicates that the debate regarding the British military-fiscal state is becoming as contentious as the debate over the Prussian military-fiscal state. This may be a result of changing cultural values in the twenty-first century, which see the development of eighteenth-century state as politically foreign enough to critique, but politically familiar enough to criticize with a modern lens. More importantly, this dissertation views the criticisms of Britain and Prussia as a sign that to many contemporary historians, the similarities of these military-

\footnotetext{
${ }^{56}$ Darren Layne, "Layne on Massie and Oates," The Scottish Historical Review, Vol. 99. No. 2, (October 2020), 316-18.

${ }^{57}$ Tony Hayter, The Army and Crowd in Mid-Georgian England, (London: Macmillan, 1978).
} 
fiscal states may outweigh their differences. By comparing the experiences of soldiers in both these states, the dissertation seeks to test that idea.

\section{THE NEW SCHOOL: RECENT HISTORIOGRAPHY OF OLD REGIME SOLDIERS}

Research into the daily lives of soldiers often focuses on warfare in the nineteenth and twentieth centuries. Fortunately a new generation of scholars has revisited soldiers prior to the Napoleonic era. The recent scholarship of Ilya Berkovich and Katrin and Sascha Möbius represents a new approach to the field, and has initiated a new school of inquiry on eighteenthcentury soldiers. Publishing their works since 2015, these historians have fundamentally altered our perception of common soldiers in Old Regime Europe, and it is worthwhile to briefly trace that historiography before discussing the average experiences of common soldiers themselves. ${ }^{58}$ Before the turn of the twenty-first century, historians did not broadly question the idea that eighteenth-century common soldiers, in the turn of phrase used by the Duke of Wellington, represented "the scum of the earth." dominated historians' perception of the common soldiers of Old Regime armies. Historians assumed that soldiers, who they believed were often coerced peasants, misfits, or criminals were not honorable or patriotic. ${ }^{60}$ Fear of their officers, according to the traditional formulation of Frederick II, motivated these soldiers. Andrew Wilson, a Professor of Strategy and Policy at the United States Naval War College, summarized this traditional view: "In general, an ancien regime army was a slow and unwieldy mass of disgruntled and terrorized soldiers led by

\footnotetext{
${ }^{58}$ Ilya Berkovich, Motivation in War: The Experience of Common Soldiers in Old Regime Europe, (Cambridge, Cambridge University Press, 2017); Katrin and Sascha Möbius, The Psychology of Honour: Prussian Army Soldiers and the Seven Years War, (London: Bloomsburg Academic, 2019).

${ }^{59}$ The full quote comes from Stanhope's conversations with the Duke of Wellington: "I may say it in this room are the very scum of the earth. People talk of their enlisting from their fine military feeling — all stuff — no such thing. Some of our men enlist from having got bastard children — some for minor offences — many more for drink" Philip Henry Stanhope, Notes of Conversations with the Duke of Wellington, 1831-1851,(London: 1889), 18. ${ }^{60}$ For a representative example of this view, see William Willcox and Walter Arnstein, The Age of Aristocracy: 1688-1830, (New York, Houghton Mifflin, 2001), 110.
} 
untrained and unimaginative officers." 61 This traditional view was challenged by the "new school" of specialized historians who have driven the research on Old Regime soldiers in a different direction, arguing that these soldiers were in fact motivated by honor, religion, localism, and state patriotism. In broad terms, then, the writings of the new school attempt to examine the place of common soldiers in the Old Regime with a critical and analytic sense of empathy in contrast to the dismissal of previous historiography. Soldiers appear in these studies, as individuals with stories, lives, and motivations, not simply as automata harshly controlled by their aristocratic officers. ${ }^{62}$ My work joins and contributes to this new school.

Berkovich and Möbius recognize British historian Christopher Duffy, a lifelong specialist in eighteenth-century warfare, as the precursor of this new school, in addition to the writings of Timothy Blanning and Dennis Showalter. English-language scholars have led the research making up the basis of the new school, and even those scholars native to, and covering topics related to German Central Europe, are increasingly publishing their findings in English. ${ }^{63} \mathrm{~A}$ significant exception to this trend is Michael Sikora's excellent book, Disziplin und Desertion: Struktureprobleme militarischer Organization im 18. Jahrhundert. Sikora stressed the importance of religion in the world of eighteenth-century soldiers, a view my research affirms. With Sikora's study, which found a middle-path between old and new interpretations, presaged the writings of a number of excellent German-language scholars on Prussian history, including the vital studies of Jurgen Kloosterhuis, Jörg Muth, Martin Winter, and Beate Engelen. ${ }^{64}$ All of

\footnotetext{
${ }^{61}$ Andrew R. Wilson, "Masters of War: History's Great Strategic Thinkers" (lecture, The Great Courses, Naval War College, Newport, Rhode Island). February $21^{\text {st }}, 2012$.

${ }^{62}$ Katrin and Sascha Möbius, Prussian Army Soldiers, 3-5.

${ }^{63}$ Ilya Berkovich, Sascha Möbius, Christopher Duffy, Timothy Blanning, Dennis Showalter and Peter H. Wilson all fall into this trend.

${ }^{64}$ Jürgen Kloosterhuis, Bauern, Bürger und Soldaten. Quellen zur Sozialisation des Militärsystems im preußischen Westfalen 1713-1803. 2 Volumes, (Münster: De Gruyter, 1992); Jörg Muth, Flucht aus dem Militärischen Alltag: Ursachen und Individuelle Ausprägung der Desertion in der Armee Friedrichs des Grossen: mit besonderer
} 
these scholars made important contributions to the literature that explores army life, desertion, social-militarization/subservience, and the bonds of family and place of women in the Prussian Army, respectively. Without the writings of these scholars, the contributions made by this dissertation would be impossible.

\section{THE WORLD OF SOLDIERS IN THE EIGHTEENTH CENTURY}

There has been a tendency on the part of recent scholarship on eighteenth-century soldiers to focus on their tactical and emotive responses to combat. Matthew Spring, in his groundbreaking 2008 work on the tactics of the British Army, wrote that "the ultimate purpose of all armies is to fight, and... therefore the most fundamental task facing the military historian is arguably to study combat." ${ }^{, 65}$ In broad methodological terms, I agree with Spring. In this dissertation, however, I am interested in examining the nature of communal links between soldiers and their communities, and as a result this dissertation will take a broader view of soldiers and their living worlds. Combat is indeed addressed, but it is not the only activity in which soldiers engaged, even if soldiers formulate combat narratives regarding its special importance in their experience. ${ }^{66}$ During the eighteenth century, soldiers spent far more time drilling, marching, cooking, and laboring than they spent in battle. These aspects of army life were perhaps not as dangerous or exciting as combat, but they were difficult and arduous enough for the soldiers performing them.

Berücksichtigung der Infanterie-Regimenter der Potsdamer Garnison (Freiburg Im Breisgau: Rombach Verl., 2003).; Martin Winter, Untertanengeist durch Militärpflict: Das Preussische Kantonsystem in brandenburgischen Städten im 18. Jahrhundert, (Bielefeld, 2005), Beate Engelen, Soldatenfrauen in Preußen: Eine Strukturanalyse der Garnisonsgesellschaft im späten 17. und im 18. Jahrhundert (Lit, 2005).

${ }^{65}$ Matthew H. Spring, With Zeal and With Bayonets Only: The British Army on Campaign in North America, xi.

${ }^{66}$ Yuval Noah Harrari, The Ultimate Experience: Battlefield Revelations and the Making of Modern War Culture, 1450-2000. 
A majority of eighteenth-century soldiers in Britain and Prussia came from the social strata of unskilled day laborers. ${ }^{67}$ In Britain, it is possible that unemployed textile works made up the next largest category, of approximately 30 percent. ${ }^{68}$ In both Britain and Prussia, men were enlisted in their early twenties, and the average soldier was approximately thirty years old. ${ }^{69}$ Army life was difficult for these men. They would march an average of fourteen miles a day, in straight last shoes that wore out easily. ${ }^{70}$ In the Itzenplitz Regiment of the Prussian Army, a soldier reckoned, that they "marched more than two hundred miles from autumn to now, and every 3rd soldier is without stocking or shoes."71 Their caloric intake was high when compared with civilian life, and contained more servings of protein. ${ }^{72}$ This high food intake was matched by the intensity of their army labor. Usually, the day would begin quite early. The Prussian regulations indicate that Reveille was beaten when visibility reached forty paces. In some armies, soldiers would immediately fall in for an accountability formation, to make sure that no one had deserted during the night. After the role was called on a campaign, the mess group would immediately begin to perform its daily tasks. In a peacetime garrison, the whole body of men

\footnotetext{
${ }^{67}$ Christopher Duffy, The Army of Frederick the Great, 75.; Glenn Steppler, The Common Soldier in the Era of George III, (unpublished doctoral dissertation, University of Oxford, 1984), 227.

${ }^{68}$ Sylvia Frey, The British Soldier in North America: A Social History of Military Life in the Revolutionary Period,, (Austin: University of Texas Press, 1981) 12.; Steppler, The Common Soldier in the Era of George III, 227.

${ }^{69}$ Willerd R. Fann, "On the Infantryman's Age in Eighteenth Century Prussia”, Military Affairs Vol. 41. No. 4. (December 1977) 168.; Glenn Steppler, The Common Soldier in the Era of George III, 229.

${ }^{70}$ This average was arrived at by examining commentaries by authors such as Clausewitz and Jomini, primary sources cited in the works of Christopher Duffy (the majority come from By Force of Arms), The Journal and Order Book of Captain Robert Kirkwood, The Papers of George Washington, in addition to manuscript sources. Straight last shoes were leather soled and not distinguished into right and left pairs. They were hard on the feet.

${ }^{71}$ Christian Zander, Fundstücke: Dokumente und Briefe einer preussischen Bauernfamilie, ( Hamburg: Kovacì, 2015) 68.

72 Fred Anderson, A People's Army: Massachusetts Soldiers and Society in the Seven Years' War, (Chapel Hill, University of North Carolina Press, 1984) 84.
} 
might perform drill after cleaning their uniforms and equipment, depending on the day of the month. $^{73}$

The complex maneuvers of drill were designed to teach the soldiers how to march quickly together as a body, to prepare them for particular motions on the battlefield, and above all, how to load and fire their flintlock weapons quickly using muscle memory. Soldiers would often comment that combat bore little resemblance to these complex drills, but that loading and firing their weapons repetitiously in peacetime was vital to ensure survival in actual combat. The process of actually loading and firing the weapon was referred to as the exercise (handgriffe), whereas more complex maneuvers and motions with large bodies of troops had more specialized terms. Officers took this work seriously, and would punish individual men, units, and more junior officers if errors were committed in the process of these maneuvers.

Daily work depended greatly on context and environment. Let us first examine the setting of a military campaign, and then turn to peacetime garrison. Usually, a large portion of the mess group would be assigned to manual labor, such as cutting wood, or digging and hauling earth. One member of the mess group might be detailed for food preparation. The army frequently sought out soldiers with particularly useful trades such as cobblers, tailors, carpenters, and masons (stoneworkers), and bricklayers. ${ }^{74}$ Soldiers were often paid slightly more for work details. Unlike peacetime garrison duty, there was relatively little "free time" in the campaign setting. Prussian Army soldier Ulrich Bräker described the nature of daily work, giving a blow by blow of the Kameradschaft's duties:

\footnotetext{
${ }^{73}$ Duffy, Army of Frederick the Great, 80.

${ }^{74}$ Alexander Campbell, The Royal American Regiment: An Atlantic Microcosm, (Norman: University of Oklahoma Press, 2010) 136.
} 
One man cleaned his musket, another did laundry, the third cooked, the fourth mended breeches, the fifth [repaired] shoes, the sixth cut wood... each tent had its six men and one extra, among these seven, one always had to be clean and prepared. Of the six remaining, one went on guard, one cooked, one fetched provisions, one gathered wood, one went after straw, one handled paperwork. ${ }^{75}$

There were, of course, exceptions to this. If the army was granted a rest day after a long march, the men would be relatively free to move about the camp, provided they did not attempt to leave the picket lines. Once again, Bräker gives us an excellent account of this type of freedom outside Pirna in 1756: "With exception of the watch, everyone could do as he pleased, bowling, horse-play, in and around the camp. ${ }^{76}$ Fires were often extinguished at sunset, and a special squad of guards was detailed to be sure that noise was kept to a minimum after sundown. In the course of a siege, the daily workload of a soldier, especially in the besieged fortress, would greatly increase. Officers noted the tiring natures of sieges and all the "various chores necessitated by siege operations." 77 In the final stages of a siege operation, it was common for the defenders to go without sleep entirely. Soldiers would work in various states of dress. During the 1759 siege of Fort Niagara, a French sortie encountered a number of British soldiers who were "naked to the waist."78

Peacetime garrison, by contrast, was a more flexible environment. After officers called the roll, and performed drill if required, soldiers were free to spend their afternoons working in the civilian sector or taking their ease. Depending on the army and year, soldiers might have lived in a fortress or barrack room, or have been quartered on the civilian population. Civilians and officers complained that soldiers grew idle and fat in peacetime service:

\footnotetext{
${ }^{75}$ Bräker, Lebensgeschichte, 143.

${ }^{76}$ Ibid

77 Pierre Pouchot, Memoirs of the Late War in North America between France and England, trans. Michael Cardy, ed. Brian Leigh Dunnigan, (Youngstown: Old Fort Niagara Association, 2004) 211

78 Ibid, 234.
} 
If the peace continues very long, I may live to see the foot [infantry] of England carried in waggons from quarter to quarter, for with their vast size and the idleness they live in, I'm sure they can't march... soon [a soldier] is incapable of wielding anything more than his musket. His hands become as delicate as a young girl, and are no longer equal to gripping a spade or pick. ${ }^{79}$

This polemic author seems to be exaggerating. Other observers took a decidedly different view. In late-eighteenth-century Prussia, a traveler found off-duty soldiers "without uniform of any kind, dirty, uncombed, some even without their breeches, going about just as they pleased. There are soldiers on every street corner, pursuing every means of employment imaginable." ${ }^{80}$ Ulrich Bräker portrays a quite similar scene in the 1750s: "hundreds of soldiers occupied themselves loaded and unloading merchant's wares, while the timber-yards were full of toiling warriors." 81 In conclusion, whether or not the army was on campaign, the life of soldiers could be quite physically laborious. Unless on a rest day, or during an afternoon lull in fortress garrison service, eighteenth-century soldiers worked industriously at the business of war, or if in an urban setting, contributed a ready workforce to the economy.

Soldiers serving far from home in a colonial environment might be called to endure even more trying hardships than in Europe. A German-speaking soldier with Burgoyne's British Army in North America commented:

The banks of the lake are covered with the thickest woods, and every time a camp had to be pitched, trees had to be cut down and the place cleared. In spite of the hard work, no other provisions were furnished than salt meat and flour. As each soldier had to bake his own bread, and no ovens for baking the same were there, he had to either bake it in hot ashes or on hot stones. This bread was, of course, very hard and heavy, and required good teeth. Furthermore there was neither whisky nor tobacco, which the German soldiers were accustomed to have. I

\footnotetext{
${ }^{79}$ Percy Sumner, "General Hawley's Chaos," Journal of the Society for Army Historical Research, Vol. 26, No. 107, (Autumn, 1948) 93.

${ }^{80}$ Jacques-Antoine-Hippolyte comte de Guibert, Journal D'un Voyage En Allemagne, (Paris: 1803) 166.

${ }^{81}$ Bräker, Lebensgeschichte ,121.
} 
consider these last indispensible for soldiers. ... It is not my intention to pity the soldier. He cannot always find things as he is accustomed to having them. He must know how to endure the hardships of his profession without murmuring. However, it would be better to prepare him rather than have him come upon these hardships unexpectedly. ${ }^{82}$

In addition to hardships generated by tropical heat in the Caribbean, India, or Africa, or the freezing weather of Canada, soldiers often faced severe shortages of food, clothing and equipment when deployed far from their country of origin. Disease, introduced to men who acted as the front line of settler colonialism, often had fatal consequences for these men during the infancy of scientific medicine. Finally, when deployed abroad in hostile environments, soldiers faced the final hardship of being separated from their families and local communities, and for common soldiers, the postal systems employed by imperial states were rudimentary even in the late eighteenth century.

The world of soldiers, then, was far less glamorous than is often depicted on the screen or canvas. Despite the fact that these men formulated narratives about the importance of combat to their lives, explicitly focusing on those narratives can distort the historical framework by making soldiers seem overly distinct from the civilian communities they were drawn from. When these men volunteered, were conscripted, or pressed into military service, their worlds changed fundamentally and forever. Despite that, before resocialization became the norm for military training, certain eighteenth-century soldiers remained closely tied with their former identities via emotive and familial bonds, and labored much as they did in civilian life. ${ }^{83}$

\footnotetext{
${ }^{82}$ August Wilhelm Du Roi, Journal of Du Roi the Elder, (Philadelphia: University of Pennsylvania Press, 1911) 9091.

${ }^{83}$ Resocialization is the process of eroding the identities of the individual in order to prepare that individual for a new type of life. In context of military training, soldiers are psychologically retrained to place the needs of the group ahead of their individual needs. Soldiers go through this process voluntarily in the twenty-first century, the detainees of prisons and mental hospitals are compulsorily subjected to it.
} 


\section{OUTLINE OF THE DISSERTATION}

A half century of warfare, two important growing martial states, and the varied world of soldiering is a lot to cover in one dissertation. In order to facilitate this story, I have organized this dissertation along thematic chapters that build on each other and illustrate the importance of transnational military history from below. My dissertation will travel through the world of the eighteenth-century soldiers in Britain and Prussia in seven chapters: Chapter one explicitly explores the transnational connections between Britain and Prussia during the eighteenth century. This chapter examines numerous travelogues by military-minded authors from both England and German Central Europe. Using archival sources and published documents, this chapter argues military authors from both states developed a discourse regarding the essential characteristics of "the other" state and their military. Englishmen decried "Prussian Slavery" as they championed “English Freedom," whereas Prussian authors were often entranced by such exotic ethnic military units, such as the Scots, in the British Army. Both sides found common ground in extolling the virtues of their martial monarchs, and were intrigued by how each state managed military discipline and understood the local allegiances of soldiers in a military setting.

Chapter two argues that common soldiers serving in both armies possessed a shared sense of local identity. In Prussia, however, the state deliberately encouraged the connections and ties between soldiers and their local communities, whereas in Britain, this occurred unevenly. The main evidence for this analysis relating soldiers to village life is found in military letters, which often contained multiple voices and marginal notations containing extra messages. The chapter draws on letters from the British, Jacobite, and Prussian armies between 1740 and 1789. These letters primarily come from the Geheimes Staatsarchiv, Brandenburgisches Landeshauptarchiv, 
British National Archives (Kew) The Templer Study Centre at the National Army Museum, and numerous smaller archives across Northern Europe.

Chapter three examines the violence committed by eighteenth-century armies against each other, as well as against civilians. The mass violence of the Thirty Years War and the French Revolution bracketed the eighteenth-century wars, and this chapter will explore this wider period in order to reexamine traditional arguments made about the concept of limited war within the eighteenth century. It examines how British and Prussian soldiers interacted with their local communities during their service. The civilian petitions that called for the removal of soldiers from their localities demonstrated the response nature of governments in civilian complaints against soldiers. After exploring the world of violence on the battlefield, this chapter turns to the violence committed by soldiers against civilians in the wider Kabinettskriege era, providing a broad context for understanding the impact of wartime violence in the second half of the eighteenth century. The chapter uses archival evidence from the British National Archives as well as the Brandenburgisches Landeshauptarchiv.

Chapters four and five examine the role of religious piety in both armies. The impact of Methodism on the British Army is explored in chapter four. I argue that Methodism became both a pro-monarchical ideology which drove Methodist soldiers to proclaim their loyalty to the king and state, and fostered an intra-army identity which allowed Methodists to differentiate themselves from other "wicked" soldiers. This will be demonstrated by a group of eighteenthcentury soldiers who combined pride in their loyalty to the state with contempt for the rakish and disorderly reputation that early modern soldiers had acquired. The primary evidence for this chapter includes a collection of memoirs by Methodist soldiers, John Wesley's correspondence with soldiers, and a letterbook/scrapbook kept by a Methodist soldier from the Templer Study 
Centre at the National Army Museum. Chapter five examines a similar process in the Prussian army. This chapter argues that Pietist religious sentiments, particularly when reinforced by personal loyalty to Frederick II, were a source of strength for common soldiers in the Prussian Army during the Seven Years' War. The king became an especially important figure in the army. Although some Prussian officers increasingly challenged Frederick II as an incompetent general, Prussian soldiers combined their respect for religious and kingly authority into the person of Frederick II, and remained loyal to him even when there were no longer rational prospects of military success. The primary evidence for this chapter comes from the letters of Prussian soldiers mentioned above, officers reports on the army, and foreign observers of the Prussian army, and published memoirs.

The important role of military relations and local communities returns in chapters six and seven. Chapter six underscores the importance of region and local sentiments for soldiers' experiences in an elite Prussian unit, Regiment von Itzenplitz, during the Seven Years War. Soldiers locally recruited in Prussia utilized letter writing to maintain village connections as described in chapter one, and foreigners in the Prussian army retained emotional bonds through connections with soldiers from similar localities. Soldiers also drew heavily on the presence of the king, as described in chapter four. The source base for this chapter comes from twenty letters and two memoirs by enlisted soldiers, court records, and descriptive writing by officers. Finally, chapter seven explores the efforts of British military administrators as they considered and attempted to transplant the Prussian practice of local recruitment of soldiers to England. This final chapter explores the logic behind the creators of the 1782 Army Reforms. These reforms aimed at the creation of a military local identity in the seventy most senior regiments of foot, and though the reform was only achieved in 1782, it had been suggested over thirty years prior by 
William Augustus, the Duke of Cumberland. This chapter argues that Cumberland, as well the man who actually carried out the reforms, General Henry Seymour Conway, were influenced by their observations of the Prussian system of local recruitment as a key source of Prussian military success, and attempted to foster locally recruited regiments within the British Army as a result. Although in the final accounting, the conscription based model of the Prussian military was not included in the reforms, Cumberland, Conway, and Prussia played an important role in the development of this previously understudied military administrative modification. This chapter is based upon research at the British National Archives, the Bodleian Library, and the Royal Archives at Windsor.

In closing, this dissertation sets out to reveal the martial experiences of two distinct but related military cultures, using a framework of transnational military history from below. Taking the practice of history from below seriously, my dissertation gives precedence and focus to the experiences and life-ways of ordinary soldiers, the largest group of men in each of these armies. Taking the concept of transnational history seriously, my dissertation seeks to question the unique character and generalized national stories of two different military cultures which shared common values and practices, and in observations of the other found inspiration for reform. Taking a broad view of the experience of violence in the eighteenth century, my dissertation explores traditional and revisionist narratives about the way soldiers and civilians experienced wartime violence during this time. Using a series of case studies, my dissertation seeks to utilize a number of different qualitative and quantitative methods and demonstrate the variety of ways that military-social history can be written in an eighteenth-century context. Taken together, these frameworks will demonstrate the importance of common soldiers and their community connections in army recruitment and organization; the ways that similar religious and 
monarchical sentiments permeated different eighteenth-century armies, and the reduced presence of violence in the eighteenth-century military world. This work ultimately asserts the importance of social, local, religious, and transnational perspectives for military historians working in the eighteenth-century world. The world of eighteenth-century armies contained their own paradoxes. Officers utilized the writings of a military-public sphere in order to improve the efficiency of armies. These armies were violent but restrained, academic but religious, and local but transnational. This dissertation sets out to demonstrate the complex and intermeshed nature of these seemingly opposed ideas. 


\section{England looks at Prussia, Prussia Looks at England: Eighteenth-Century Military Travelogues}

In the summer and autumn of 1774, David Scott conducted an epic tour of the European continent. Beginning on June $8^{\text {th }}$, traveling by ship, coach, horse, and foot, he covered over 5,000 miles before returning to London around the end of November. Scott lived in a time in which European tours were commonplace for upper-class educated Englishmen. For a few, these tours formed a requisite for entering into manhood: they were the capstone of a formal education. ${ }^{84}$ In a neoclassical age, these tours prioritized travel to Italy, such leading cities as Venice, Florence, and Rome to become a tourist trap for a milieu of European nobility. European tours were designed to allow men of a certain class to meet, discuss politics and art via the medium of the French language, study the art architecture of the classical world, and perhaps indulge in unsavory pleasures. Indeed, Scott's tour occurred during the apogee of this English-led but European-wide phenomenon. Surprisingly, then, Scott's tour did not include Italy on the itinerary. Indeed, his tour, and the others like it, were part of another phenomenon which emerged out of the travel writing resulting from the Grand Tour. Scott travelled across Europe, not to see the architecture and converse on art and poetry in French, but in contrast observe the military states of Europe. His itinerary failed to include Venice, Rome, or Naples, but included military centers such as Kassel, Weiner Neustadt, and that hotbed of militarism: Potsdam. Scott undertook this tour "with the greatest chearfullness," not at the behest of a father or uncle

\footnotetext{
${ }^{84}$ For important literature on travel writing in Europe during the eighteenth century, see: Wolfgang Griep and Jäger Hans-Wolf, eds., Reisen im 18. Jahrhundert: Neue Untersuchungen (Heidelberg: C. Winter, Universitätsverlag, 1986), John Eglin, Venice Transfigured: the Myth of Venice in British Culture, 1660-1797 (New York: Palgrave, 2001), Rainer Babel and Werner Paravicini, eds., Grand Tour: Adeliges Reisen und europäische Kultur Vom 14. bis zum 18. Jahrhundert: Akten der Internationalen Kolloquien in der Villa Vigoni 1999 und im Deutschen Historischen Institut Paris 2000 (Ostfildern: Thorbecke, 2005), Elizabeth A. Bohls and Ian Duncan, eds., Travel Writing, 17001830: an Anthology (Oxford, UK: Oxford University Press, 2008), Peter Hulme and Tim Youngs, eds., The Cambridge Companion to Travel Writing (Cambridge: Cambridge University Press, 2013),dMathis Leibetseder, Kavalierstour - Bildungsreise - Grand Tour: Reisen, Bildung und Wissenserwerb in der Frühen Neuzeit (Mainz: Leibniz-Institut für Europäische Geschichte, 2013).
} 
wanting to provide a final step in his formal education, but accompanying a prominent British General, Henry Seymour Conway. ${ }^{85}$

Between 1739 and 1789, European travelers produced a growing body of literature which observed neighboring and distant lands. This chapter taps into a specific section of that writing: travelogues which were, based upon the military or civilian authors who wrote them, intentionally or unintentionally military in nature. These travel narratives, far from merely describing 'military Europe' in the eighteenth century, put forth broad arguments about common soldiers, their worldviews, and the way they related to society. Though usually written by officers or civilian intellectuals, these narratives provide historians with one approach for exploring the military-civil relationship in England and Prussia during the second half of the eighteenth century. More importantly, these narratives show us the ways in which reading publics in both England and Prussia conceptualized the other state during this pivotal era.

This chapter explores the world of military travelogues in England and Prussia during the second half of the eighteenth century. In it, I argue that during their "Military Grand Tour," these travelers wrote broad commentaries on the militaries and societies they encountered, not specialist treatises devoted to military minutia. These military travelogues tapped into a broader societal discourse regarding military affairs across Europe, what I will call the military public sphere. This public sphere, found in most European states from Spain to Russia, has been previously examined by historians working on the military enlightenment in individual states. ${ }^{86}$ These documents connected commentaries on both militaries and the societies that constructed

\footnotetext{
${ }^{85}$ Bodleian Library, MS Eng. Hist. C 282, "Narrative of General Conway's Tour”, 1.

${ }^{86}$ Christy Pichichero, The Military Enlightenment: War and Culture in the French Empire from Louis XIV to Napoleon,(Cornell: Cornell University Press, 2017), Ira Gruber, Books and the British Army: in the Age of the American Revolution,(Chapel Hill: University of North Carolina Press, 2010), Eugene Miakinkov, War and Enlightenment in Russia: Military Culture in the Age of Catherine II, (Toronto: University of Toronto Press, 2020).
} 
them. At times, civilian authors commented on military affairs; likewise, military authors felt comfortable discussing the societal underpinnings of military affairs. Most importantly, these documents demonstrate that far from presenting a widening gulf between the military and civilian society, both military and civilian intellectuals were concerned with military and societal affairs. As they toured the landscape of military Europe, these observers sought to take the pulse of the military-civil relationship in the states where they traveled.

These travelogues come in many different forms, produced by many different authors. Military reformers wrote some of the more extensive tour narratives, whereas civilians often addressed military affairs in passing. Some were published; others remain only in manuscript form. David Scott's manuscript, “A Military Tour of Europe in 1774," remained unpublished and is accessible in manuscript form at archives in the Bodleian Library. In describing his tour with British General Conway, Scott holds forth on the various militaries of Central Europe, their relationship to civil society in their own states, and their comparative military strengths. Feldmarschall Christian Ludwig von Hardenburg penned a similar document in the earlier part of the eighteenth century. Never published, it is a detailed report of England, made for the benefit of the Hanoverian kings. Though Hardenburg's report contains a great deal of military information, it also comments widely on the religious and political state of England. ${ }^{87}$ The unpublished travelogue was eventually deposited in the Staatsarchiv Potsdam due to the Prussian connections of Hardenburg's family. By contrast, Karl Phillip Moritz, the son of a Prussian regimental musician, conducted a walking tour through England in 1782 and noted military details in passing. Moritz gathered his recollections into a book for publication, and after it

\footnotetext{
${ }^{87}$ BLHA, Rep 37 Neuhardenburg Nr. 1571, "Militaria Anglica".
} 
appeared in German his work was subsequently translated into English for the Anglophone reading public.

These touring narratives conversed with one another, sometimes explicitly, regarding key military-social debates in the eighteenth century. ${ }^{88}$ For example, multiple authors took on the question of whether the Prussian canton system was oppressive, whether Englishmen truly had more freedoms than the people of Central Europe, the role of monarchs in war, what motivated common soldiers, and above all, how to construct the ideal army. These themes, far from only being of interest to contemporaries, help frame this dissertation. The differences and similarities of the English and Prussian military systems lie at the heart of this transnational project. As a result, to help frame this work, this opening chapter will evaluate how the English and Prussians formed stereotypes about one another, using the published and unpublished narratives of military and civilian intellectuals at the time.

\section{TRAVELER BIOGRAPHIES AND STARTING QUESTIONS}

In the first half of the eighteenth century, British soldiers' travelogues of Prussia are rare. One notable example is the 1732 travelogue of Alexander Dury, who traveled to Hanover and Prussia in his capacity as an officer of the Guards. As a result of the celebrity status gained by the Prussian monarchy and army in the latter half of the century, many more English-speaking military-minded intellectuals travelled through Prussia after 1750. These included famous generals, such as Charles Cornwallis and John Burgoyne, less well-known military reformers and intellectuals such as Robert Jackson, David Dundas and Henry Seymour Conway (who was accompanied by David Scott), and civilians commenting on the state of military affairs, such as

\footnotetext{
${ }^{88}$ Johann Kaspar Reisbeck made the most complete attempt to survey the published military travel literature and place it in conversation with his own thoughts. See Briefe eines reisenden Franzosen über Deutschland an seinen Bruder zu Paris, (1784) 2: 89-111.
} 
Dr. John Moore and Joseph Johnson. One American, Colonel William Stephens Smith, has been included with the other "Anglo" observers. Fewer Prussians wrote on their travels to England. In the earlier part of the century, the Prussian intellectual and officer's son Karl Ludwig, Freiherr de Pollnitz wrote an extensive travelogue and included letters from England. In the later portion of the era, one military officer, Captain Johann Wilhelm von Archenholz, who coined the term “Seven Years War,” and one soldier's son, Karl Phillip Moritz, wrote extensively on their travels in England. A Saxon officer and intellectual who briefly served in the military, Johann Gabriel Bernhard Büschel, responded to Karl Phillip Moritz's work directly in his own book, which was published in the following year. Furthermore, authors from German Central Europe such as Viennese bookseller Johann Kaspar Reisbeck felt it was their duty to comment on both Prussia and England.

Travelers wrote (and often published) their travelogues for a variety of reasons. Travelogues could assist their authors in professional advancement, gain a powerful patron through the dedication of a work, become known to a Pan-European intellectual reading circle, and of course, earn income through the sale of books. Many of the published works by military and civilian intellectuals need to be read with extreme care; unpublished manuscripts which appear in archival collections often contain details which are edited out of publicized travelogues. It is vital to realize that none of these travelogues represent England or Prussia accurately. Often, these observations tell historians more about the worldview of the writer than about the society being observed. What is vital about these sources is that they were written, published and consumed by a military public sphere, which provided militarily-interested individuals living in both England and Prussia a supposed window onto the other military society. 
Although the authors debated a large variety of points, most of them were connected to five key issues. First, what role did they believe the monarchy played in the governance of the military state? Second, how did the travel writers observe interaction between common soldiers and civilians in Britain and Prussia? Third, what did contemporaries believe motivated Prussian soldiers: draconian discipline, or an attachment to place? Fourth, did contemporary authors adhere to the stereotypes that Englishmen were free and Prussians oppressed? Fifth, and finally, how did the authors envision locality playing into the motivations of common soldiers? By exploring the ideas of contemporary military and civilian intellectuals on these questions, this chapter will accomplish two goals. First, it will introduce the reader to contemporary viewpoints common to eighteenth-century authors, and second, it will continue to develop the major themes of this dissertation.

\section{TRAVELOGUES AND MILITARY MONARCHS}

As military-intellectual travelers passed through European states, they often found a public eager to hear stories regarding martial feats, and recorded stories of famous personalities from foreign lands. Guards' Officer Alexander Dury left a travelogue of the Prussian court before 1740. Dury appears to have picked up little tension at the Prussian court. The crown prince, the future Frederick II ("the Great") of Prussia, had recently been released from his semiimprisonment at the fortress of Küstrin. Instead of examining this tension, Dury focused on Frederick William I and his court, in which Prussians always had food available, and he noted that the men of the king's entourage were, "corpulent... but mighty good natured." ${ }^{89}$ Frederick William I impressed Dury, and like many travelers to the court of the so-called Soldier-King, Dury felt compelled to take notice of the extraordinarily tall soldiers which Frederick William I

\footnotetext{
${ }^{89}$ National Army Museum, London (NAM) 1986-12-38-116.
} 
had collected from across Europe. Unlike many of those observers, however, Dury noted in his 1732 visit that the Prussian army was perhaps a force to be reckoned with. ${ }^{90}$ He noted the large arsenal, and that it contained enough weapons to arm a large number of infantrymen and cavalrymen, with hundreds of spare artillery pieces and mortars.

After Frederick William I died in 1740, Prussia spent many of the next twenty-five years at war. By 1765, most English-speaking military men felt compelled to discuss Frederick II in their travelogues. ${ }^{91}$ Depending on their political persuasion, even military men could believe that the king of Prussia was a tyrant, but most seemed obsessed with learning from his enlightened military ideas and practices. One military writer called him "a second conqueror of the world," perhaps a reference to Alexander the Great. $^{92}$ Englishmen recognized Frederick II as a celebrity after the Seven Years War. Even in 1782, during the American War of Independence, an English innkeeper in Derby pressed Karl Philip Moritz for anecdotes regarding Frederick II and the Prussian military. ${ }^{93}$ Dr. John Moore examined Frederick II at length in his travelogue, and was clearly impressed by him, ending a discussion with the note, "the perseverance of the king of Prussia is without example, and is perhaps the most remarkable part of his extraordinary character." Monarchs were not always popular with their own subjects or the subjects of other states, but Frederick II held a particular appeal, and travelers with an eye for military details often discussed the Prussian monarch.

\footnotetext{
90 Ibid.

${ }^{91}$ NAM, 1968-07-256, 36-38; British Library, King's Manuscripts 241, 36.

${ }^{92}$ Fransisco de Miranda, Archivo del General Miranda, (Caracas: Parra Leon Hermonas, 1929) 1:383, 400.

${ }^{93}$ Carl Phillip Moritz, Reisen eines Deutschen in England im Jahr 1782, in Briefen an Herrn Oberkonsistorialath Gedike, (1783), 185-6.

${ }^{94}$ John Moore, A View of Society and Manners in France, Switzerland, and Germany, (London: 1770) $2: 142$.
} 
Indeed, it is one of the travelogues, written for the benefit of the American Washington by his aide, the Marquis de Lafayette, that has provided one of the most enduring (if distorted) images of Frederick II:

I...could not help being struck with the dress and appearance of an old, broken, dirty corporal, covered all over with Spanish snuff, with his head almost leaning on one shoulder, and fingers almost distorted by the gout ; but what surprises me much more is the fire, and sometimes the softness, of the most beautiful eyes I ever saw, which give as charming an expression to his physiognomy, as he can take a rough and threatening one at the head of his troops. ${ }^{95}$

This specific description led to an enduring image of Frederick as "Old Fritz": a wizened and aged but fierce and fair military man. As a result of observations like this one, Frederick took on the status of a pan-European celebrity. In England, France, and even the young United States, Frederick "the Great" took on the panoply of a military hero, like Charles XII a generation before, and comparable to the ancient military heroes well-known by all educated young men in the Atlantic World. These men, on both sides of the Atlantic, had read Voltaire's history of Charles XII, and naturally compared these two military figures. Of all eighteenthcentury European monarchs, Frederick II possessed a particular status as a warrior king, leading his armies from horseback in the field with his men.

At the same review in 1785, Charles Cornwallis criticized Frederick and his army for military backwardness. At this point in his life, Cornwallis had served with distinction in the Holy Roman Empire during the Seven Years War, and just returned from his defeat in America. He complained that his "reception in Silesia was not flattering; there was a most marked preference for La Fayette; whether it proceeded from the king's knowing more of France, and

\footnotetext{
${ }^{95}$ Marquis de Lafayette, Memoirs, Correspondence and Manuscripts of General Lafayette, (London: 1837) 2:121. For a similar description see, Reisbeck, Briefe eines reisenden Franzosen, 2:89.
} 
liking better to talk about it, I know not.."${ }^{96}$ Although he was a noted Francophile, Frederick's preference for Lafayette might have been derived from the fact that he was the victor in the recent American conflict. Cornwallis found the Prussian army somewhat less than impressive and criticized its troops: "The cavalry is very fine; the infantry exactly like the Hessian, only taller and better set up, but much slower in their movements. Their manoeuvres were such as the worst General in England would be hooted at for practicing." ${ }^{97}$ As Matthew Spring has shown, the British Army fought a fast-moving aggressive war in North America during the Revolutionary War, so it perhaps unsurprising that the slow Prussian movements met with Cornwallis' censure. Cornwallis's preference for fast-moving tactics set him directly at odds with Scottish reformer David Dundas, also present at the 1785 review. A relatively junior officer in 1785, Dundas's observations of the Prussian Army would lead to a reform movement, when would eventually write his own books, and shaped British Army tactics during the War of the First Coalition and throughout the Napoleonic era. Dundas is the classic example of a British officer interacting within the military public sphere.

George II was acknowledged as a martial king, at least by a minority of Britons. When he was traveling through Derbyshire Karl Moritz encountered an innkeeper who competed with tales of Frederick II of Prussia by sharing anecdotes about George II: "In our chat, we talked much of George the second, who appeared to be his favourite king; much more so than George the third. And among other things, we talked of the battle at Dettingen, of which he knew many particulars. ${ }^{" 98}$ The Battle of Dettingen in 1743 was the last time George II (or any British monarch) directly commanded an army in battle, so it makes a sort of sense that a Briton of the

\footnotetext{
${ }^{96}$ Charles Cornwallis, Correspondence of Charles, First Marquis Cornwallis, (London: 1859) 1:212.

${ }^{97}$ Ibid.

${ }^{98}$ Moritz, Reisen eines Deutschen 186.
} 
type described by Linda Colley, whose reputation was built in military conflict against Catholic France, would take pride in George II. British suspicion of large standing armies did not necessarily mean a lack of support for a martial monarch, particularly if that monarch was now deceased and no longer posed a threat to English liberties. Although military authors wrote more on Frederick II as a result of his status as a European celebrity, they covered military monarchs generally, as a result of their importance to eighteenth-century military affairs.

\section{TRAVELOGUES ON SOLDIER-CIVILIAN INTERACTIONS}

As both military and civilian travelers moved across Britain and Prussia, they commonly noted how soldiers and civilians interacted in the states they visited. Prussians travelling in England were somewhat surprised by the lack of a military presence in such large cities such as London, whereas English travelers were sometimes shocked by the large number of soldiers in Prussia. The English travelers in Prussia also wrote extensively regarding the nature of military labor, and the civilian trades that off-duty Prussian soldiers were allowed to pursue. As these travelers made notes on the societies they encountered, they often explained more about their own viewpoints than those they encountered.

In England, Prussian observers noted the presence of common soldiers, particularly in urban settings. Karl Phillip Moritz, though the son of a soldier, seemed to esteem fighting men rather little. When discussing his stay at an inn near Richmond outside of London, Moritz described a group of clientele which "consisted chiefly of soldiers, and low fellows." "99 These soldiers, together with some civilians, "were drinking and singing songs, in which, as far as I

could understand them, there were many passages at least as vulgar and nonsensical as ours."100

\footnotetext{
${ }^{99}$ Moritz, Reisen eines Deutschen, 136.

${ }^{100}$ Ibid.
} 
Though Moritz seemed to accord soldiers a relatively low social standing, he noted that the soldiers enjoyed Richmond in a mixed company in a public house.

Captain Archenholz found himself quite surprised that in England, soldiers could be punished by civil authorities, and addressed the subject at some length:

As the military are wholly subordinate to the civil power, and as an officer has no right to punish a soldier for anything but the neglect of his duty, it is not at all uncommon to find many of them confined in all the gaols of the kingdom, on account of debt, or a criminal prosecution. A foreigner, and especially a German, who has been used to behold the army, on every occasion, treated as a body altogether separate and distinct from the people, is extremely astonished at this custom. $^{101}$

At first glance, Archenholz seems to suggest that in Prussia, the military and civilian worlds are distinct, whereas in Britain they are far more integrated. A close reading of the following passage, however, implies that Archenholz believed that this was potentially an opportunity for civilian authorities to oppress soldiers, particularly foreign soldiers. He continued:

A former soldier of Prussian Guard Regiment, who had served in Germany during the great war, where he had learned much of the military art, some years after the peace, stood as a sentinel in the park, and took hold of a gentlemen's hat while he relieved himself, soon found that this German custom was not tolerated in England. The gentleman immediately applied to a magistrate and received a warrant, swearing that the soldier had stolen his hat by force in public. The soldier was accordingly seized, , condemned, and would have been actually executed, if the king had not granted him a pardon. ${ }^{102}$

Archenholz's narrative bears a striking similarity to the Affair of the Hanoverian Soldier, a mid-eighteenth century cause célèbre, where a soldier was accused of stealing a neckerchief

\footnotetext{
${ }^{101}$ Johann Wilhelm von Archenholz, England und Italien, (Leipzig: Dykischen Buchhandlung, 1787) 2:191-192. ${ }^{102}$ Ibid.
} 
from a store in Maidstone, Kent. ${ }^{103}$ The narratives that run through the story emphasize a grasping, unforgiving view on the part of civilians towards soldiers, an English mistrust for foreigners and foreign customs, and tellingly, the role of the monarch in supporting soldiers, and perhaps, ethnic Germans.

Moritz seems to have been disappointed by the lack of respect for religion among the English soldiers he encountered: "Two soldiers, who sat near me in the church, and who had probably been in London, seemed to wish to pass for philosophers, and wits; for they did not join in the prayers of the church." ${ }^{, 104}$ Later he encountered "some soldiers who were intoxicated with strong spirits as I was looking at a church...they said, it was only a very miserable church. On which I took the liberty to inform them, that no church could be miserable, which contained orderly and good people." ${ }^{105}$ To a degree, Moritz's reproach can be attributed to the idea that in Prussia, soldiers often respected religion and embraced religious teachings, as evidenced in their letters, songs and worship (see chapter five).

Karl Moritz also keenly noted the absence of regulation when moving between urban and rural spaces in England. In an odd reversal of the observations of John Moore and David Scott above, Moritz was shocked to see a lack of fortifications and guards around English towns:

It strikes a foreigner as something particular and unusual, when, on passing through these fine English towns, he observes none of those circumstances, by which the towns in Germany are distinguished from the villages, no walls, no gates, no sentries, nor garrisons. No stern examiner comes here to search and inspect us, or our baggage ; no imperious guard here demands a sight of our

\footnotetext{
${ }^{103}$ Mathew McCormack. "Citizenship, Nationhood, and Masculinity in the Affair of the Hanoverian Soldier, 1756." The Historical Journal 49, no. 4 (2006): 971-93

${ }^{104}$ Moritz, Reisen eines Deutschen 147.

${ }^{105}$ Ibid, 156 .
} 
passports : perfectly free and unmolested, we here walk - through villages and towns, as unconcerned as we should through an house of our own. ${ }^{106}$

Moritz's observations likely have less to do with the innate freedom of Britons than with the political and strategic landscapes of eighteenth-century Europe: English cities could lack fortifications as a result of their location on an island, the protection of the sea, and the Royal Navy. Towns in continental Europe, not only in Prussia but also places such as Piedmont, France, the United Provinces, and throughout the Holy Roman Empire, all possessed the sensible fortifications that English towns could afford to do without. ${ }^{107}$

A Saxon intellectual and soldier, Johann Büschel, writing a year after Moritz, could not help but be impressed with the Tower of London, not as a fortress, but as an armory. In 1783, at the end of the American War of Independence, he noted, "This arsenal for the whole army, from which a hundred thousand men could be armed, was even more impressive before the war than now."108 "The Tower itself inspires awe," he continued, "as foreign ships continually greet it with resounding salutes of cannons. A company of lifeguards permanently resides there." 109 Finally, with a tone approaching astonishment, he noted:

the tower is the only part of the city in which one can see military activity. The horse and foot guards lie at Westminster...but all these soldiers are in no great respect, for they serve only for the estate of the king...even in the great rebellion, they did not do anything, but had to watch quite calmly, and be roundly insulted, except if called upon by express parliamentary order. At last the order was given to call against the rebels. 110

\footnotetext{
106 Ibid, 118.

${ }^{107}$ For an excellent summary of the nature of fortifications in early modern Europe, see Christopher Duffy, Fire and Stone: The Science of Fortress Warfare, 1660-1800 (London: Peters, Fraser, and Dunlop, 1975); Yair Mintzker, The Defortification of the German City, 1689-1866, (Cambridge: Cambridge University Press, 2012).

108 Johann Büschel, Neue Reisen eines Deutschen nach und in England im Jahre 1783, (Berlin: Friedrich Mauer, 1784) 146.

${ }^{109}$ Ibid.

${ }^{110}$ Ibid, 237.
} 
Büschel's comments regarding a rebellion likely refer to the Gordon Riots of 1780, when troops were called to end the disturbances. He also noted how the English army was used against its own people. The illegal smuggling of goods was a scourge for officials in both Britain and Prussia, and they frequently used soldiers in order to crack down on smugglers and other criminals. Discussing the repression of smugglers, Büschel noted, "The government knows this illicit trade, [and] has lately... confiscated much of it by using a particular squad of soldiers, but this has not stopped it entirely." ${ }^{\prime 11}$ British soldiers were used throughout the eighteenth century as enforcers of government police. Throughout the century soldiers violently repressed riots, smugglers, and protestors in addition to armed Jacobite rebels. ${ }^{112}$

In Prussia by contrast, English-speaking travelers were surprised, even horrified, by the presence of soldiers in urban spaces. Dr. John Moore recalled that "on entering the Prussian garrison towns, you are stopped at the gate; the officer of the guard asks your name, whence you come, whither you are going? and takes your answers down in writing."113 David Scott noted the same practice in 1774, but was somewhat less aghast, as he was traveling in the suite of the respected General Conway. ${ }^{114}$ Dr. Moore was also "not a little surprised, while I walked through the town, to see buff-belts, breeches and waistcoats, hanging to dry from the genteelest looking houses, till I was informed that each housekeeper has two or more soldiers quartered in his house." ${ }^{115}$ Moore continued on this theme for some length, informing his readers that because Prussian soldiers were impressed into service, it would be more "suited to their genius" to be quartered in barracks. He explicitly compared this with the situation in England, noting that the

\footnotetext{
${ }^{111}$ Ibid, 84.

${ }^{112}$ For a further discussion of the use of soldiers against smugglers and rioters in England, see Tony Hayter, The Army and the Crowd in Mid-Georgian England, (London: The MacMillan Press, 1978).

113 John Moore, A View of Society and Manners in France, Switzerland, and Germany, 2:114.

${ }^{114}$ Bodleian Library, MS Eng. Hist. C 282, "Narrative of General Conway's Tour", 38.

115 John Moore, , A View of Society and Manners in France, Switzerland, and Germany, 2: 121.
} 
British government had always preferred the solution of using barracks to house soldiers, but that the genius of freeborn Englishmen was more suited to the practice of quartering troops in houses. $^{116}$

Observers of Prussia found the army and civilian society closely interconnected. Sir David Dundas praised the pattern of furloughing men home from the Prussian Army during peacetime as well as the practice of allowing soldiers to work at trades while in garrison. Dundas repeatedly asserted the importance of allowing off-duty soldiers to work in civilian trades." ${ }^{117} \mathrm{He}$ believed that, "The country [Prussia] derives...benefit from the Labour of the Soldier."118 While observing Prussian troops in Wesel during the 1770s, Dundas noted, "in the streets or off duty, not clean; on duty very clean." 119 Though it would be naïve to take the sentiments of Dundas, a noted Prussophile, at face value, at the very least his narrative provides an alternative perspective to the stereotype which many English repeated: that the army ran roughshod over the civilian population in Prussia.

London bookseller Joseph Johnson translated a French travelogue by the Comte de Guibert on army life in Prussia, which emphasized the different experiences of native and foreign soldiers in the Prussian Army during peacetime. The native men could expect to be sent home to their villages, unlike foreign soldiers:

This privilege is allowed only to the natives of Prussia, the foreigners being permitted to work only within the walls of a town. These workmen, who have the name of Freywachter, are obliged to appear at the roll-call, to sleep every night at their quarters, and to be under arms occasionally when the regiment is exercised. Like the [furloughed troops] they are strictly disciplined in April and May, and

\footnotetext{
116 Ibid, 122-23.

${ }^{117}$ British Library, King's Manuscripts 241, f.35

118 Ibid.

${ }^{119}$ British Library, King's Manuscripts, 240, f. 5.
} 
during these two months they receive their pay themselves. In the great towns, such as Potsdam, Berlin, Breslau, Konigsberg, \&c. most of the Freywachters are employed at their trades, or in private families, in the capacities of coachmen, grooms, \&c. ${ }^{120}$

Guibert and Dundas's reports on Prussia portray a world where military men learned trades, and worked alongside the civilian population, rather than a world where civilian needs were firmly subordinated to state control. In these travelogues, soldiers appear as more than simple applicators of violence: they are men who productively work in the civilian economy. Guibert's closing comment on the subject indicates that people of Britain have nothing to fear from the standing Prussian army: "From what has been said, the Reader will perceive that the greatest part of the Prussian army is in fact a militia; by which...the state gains much from the labour of so many men." ${ }^{121}$ In describing the Prussian Army as a militia, Guibert referred to the system of furloughing native cantonists in Prussia during peacetime, when soldiers spent a large portion of the year at home in their village communities, and not permanently stationed with their regiments. Militias, as opposed to regular standing troops, held no terrors for Britons during the eighteenth century. By translating Guibert's description of the Prussian Army using the word 'militia', Johnson argued that these part-time soldiers were more like a militia, and made a conscious choice to allay the fears of British readers, rather than point out that Prussia had a sizable standing army.

\section{DISCIPLINE AND PLACE IN PRUSSIAN SOLDIERS’ MOTIVATIONS}

Even as English military thinkers praised the supposed genius of Frederick II, they critiqued his military system. Even before the age of Frederick II of Prussia, English travelers associated the kingdom and its military with discipline. Alexander Dury, a young officer of the

\footnotetext{
${ }^{120}$ Jacques-Antoine-Hippolyte comte de Guibert, trans. Joseph Johnson, Observations on the military establishment and discipline of the King of Prussia, (London: Fielding and Walker, 1780) 81.

${ }^{121}$ Ibid.
} 
guards who accompanied King George II on a tour through the courts of Europe in 1732, made particular note in his diary on arriving to Potsdam:

Went to the parade at Potsdam, where the king was present and the Prince Royal, the parade consisted of 300 men, two battalions of the great grenadiers in Potsdam of 700 men each, besides those there are near 700 supernumerary Grenad[iers]. They are very regular in all their motions, very clean about their arms and dress, and very strict in their discipline. ${ }^{122}$

English descriptions of Prussian discipline took on a life of their own in the later eighteenth century. If some Englishmen, such as Dury above, noted it in passing, others devoted whole paragraphs to the inner workings of obedience in Prussia. For many English military men and civilian intellectuals, the subject became one of almost morose fixation. John Moore devoted no fewer than three chapters of his travelogue to describing "Prussian Discipline," going so far as to include conversation with a Prussian officer on the subject. In this possibly fictional dialogue, Moore observed a soldier being beaten, and pressed the officer to explain why the Prussian military system was so cruel. The officer responded, "Everything must be considered as of importance by a soldier... which his officer orders him to do.” The unnamed Prussian continued: "In all probability, the fault was involuntary but it is not always possible to distinguish in voluntary faults from those that happen through negligence. To prevent any man from hoping that his negligence will be forgiven as involuntary, all blunders are punished." ${ }^{123}$ Moore continued on this theme for pages, using three different types of examples of unjust punishment to attempt to persuade his Prussian acquaintance of exaggerated discipline, but the Prussian did not relent.

\footnotetext{
${ }^{122}$ NAM, 1986-12-38-116.

${ }^{123}$ Moore, A View of Society and Manners in France, Switzerland, and Germany, 2:160.
} 
Many Anglophone observers connected Prussian military discipline to low morale among the Prussian army and a propensity among Prussian soldiers to desert. American Colonel Smith noted that Frederick's “military abilities are undoubtedly great and had he the affections of his army he might be a second conqueror of the world - his armies are composed of dissatisfied mercenaries, compelled by severity of discipline to discharge their duty." ${ }^{124}$ Johnson's translated work notes that though the military strength of Prussia might appear great, "this is perhaps not so much owing to the intrinsic bravery of his troops, as to the excellence of their discipline." ${ }^{25}$ John Burgoyne noted: "The king of Prussia deprived of such principles to work upon, turns his defects to advantage, and substitutes a species of discipline wherein the mind has no concern." ${ }^{126}$ Robert Jackson believed that "the Prussian soldiery may be supposed, in consequence of a rigid drilling, to have acquired certain mechanical habits, at the commencement of a war, which were capable of giving them advantages in action over a less experienced enemy."127 James Boswell visited Prussia just after the Seven Years War, and observed a Prussian regiment drilling. Boswell recorded that "the soldiers seemed in terror. For the least fault they were beat like Dogs." ${ }^{128}$ Far from believing this hindered the Prussian Army, however, Boswell continued, "I am, however, doubtfull if such fellows don't make the best soldiers. Machines are surer instruments than men."129 This presentation of soldiers as machines formed an enduring stereotype, strong enough to have been reproduced in modern scholarship, which this dissertation will address in chapter three.

\footnotetext{
${ }^{124}$ Miranda, Archivo del General Miranda, 1:383.

${ }^{125}$ Guibert, trans. Johnson, Observations on the military establishment and discipline of the King of Prussia, 3.

${ }^{126}$ Edward Fonblanque, Political and Military Episodes in the Latter Half of the Eighteenth Century, (London: MacMillan, 1876), 65.

${ }^{127}$ Robert Jackson, A Systematic View of the Formation, Discipline, and Economy of Armies, (London: Stockdale, 1804), 68.

${ }^{128}$ James Boswell, Journal of his Swiss and German Travels, (London: 1764), 95.

${ }^{129}$ Ibid.
} 
Observing the Prussian army in 1766, John Burgoyne (famous in American history as the man defeated at the Battle of Saratoga) railed against the Prussian service. Burgoyne claimed, "the ranks are filled up, perhaps more than a third part, with strangers, deserters, prisoners and enemies, of various countries, languages, and religions." ${ }^{130}$ His account continued, "They cannot therefore be actuated by any of the great moving principles which usually cause extraordinary superiority in armies ; they have neither national spirit nor attachment to their prince, nor enthusiasm[.]" ${ }^{131}$ Burgoyne's comment is fascinating, as it shows the extent to which English, Welsh, Scottish, and Irish recruits into the British Army had become "Britons" to this particular officer. The ethnic, religious, and linguistic differences in Burgoyne's own service, at least in his mind, had been papered over by a national identity. Burgoyne concluded, "The first principle of the Prussian system is subordination, and the first maxim 'not to reason, but to obey."'132 Burgoyne's key point, though, is important to consider. He believed that because many Prussian soldiers had no connection to place, that they could not be motivated by "national spirit, attachment to their prince, nor enthusiasm." 133

Another British officer who served in America during the War of Independence, Robert Jackson, came to different conclusions regarding the motivation of Prussian common soldiers. Mere discipline was not enough to explain the experiences of eighteenth-century soldiers, as Ilya Berkovich, Michael Sikoura and Sascha Möbius have all recently argued. ${ }^{134}$ Jackson, a medical officer in the British $71^{\text {st }}$ Regiment of Foot, reached this conclusion in the late eighteenth

\footnotetext{
${ }^{130}$ Fonblanque, Political and Military Episodes in the Latter Half of the Eighteenth Century, 65.

131 Ibid.

132 Ibid.

${ }^{133}$ Ibid.

${ }^{134}$ Ilya Berkovich, Motivation in War: The Experience of Common Soldiers in Old-Regime Europe, (Cambridge: Cambridge University Press: 2017), Michael Sikoura, Discinplin und Desertion: Strukturprobleme militärischer Organisation im 18. Jahrhundert, Historische Forschungen 57, (Berlin: Duncker und Humboldt, 1996), Sascha Möbius, Mehr Angst vor dem Offizier als vor dem Fiend? Eine mentalitätsgeschichtliche Studie zur preußischen Taktik im Siebenjährigen Krieg (Saarbrücken: VDM Verlag, 2007).
} 
century, and his observations remain fascinating. Jackson wrote, "Something is still wanting to account for the conduct of the Prussian troops, which rose above anything that can be expected to arise from an impulse of fear or coercion."135 In Jackson's view,

Heroic acts do not originate in fear: yet the acts of the Prussian soldiers were often heroic...The native Prussian, irritated and inflamed against the invaders of his country (for the peasant venerates the soil which protects the ashes of his fathers), became ardent in defence; the old soldier was proud of his renown; the recruit, whether forced or trepanned, was carried away in the torrent; he imbibed a sensation of glory from anticipated success, — and became proud in himself. ${ }^{136}$

Jackson's poetic musings are romantic in the extreme, but stand as almost completely antithetical to Burgoyne's argument: Jackson believed that because Prussian soldiers were connected to place, they were motivated by something higher than fear and coercion. John Moore also noted the importance of family connections in the lives of common soldiers in the Prussian army. ${ }^{137}$ David Dundas noted that "the native part of the Prussian Army is composed of a better kind of man, than that of any other nation."138 This Dundas refers to a "better kind of man" to indicate that as a result of conscription Prussian soldiers came from a different section of society than other armies. Dundas also noted that foreigners in the Prussian service, "many of them from marriage, habit, etc, are attached to the country." ${ }^{139}$ Even the foreign soldiers, Dundas indicates, are in the army as a result of more than mercenary reasons. Although English commentators failed to reach a firm consensus regarding the Prussian army and its motivation, most writers agreed with the stereotype that discipline outweighed the nativist motivations available to part of the army. These English authors also observed, however, that Prussians were ruled by a despotic

\footnotetext{
135 Jackson, A Systematic View of the Formation, Discipline, and Economy of Armies, 70.

${ }^{136}$ Ibid.

${ }^{137}$ Moore, A View of Society and Manners in France, Switzerland, and Germany, 2:209.

138 British Library, King's Manuscripts 241, 36.

${ }^{139}$ Ibid.
} 
monarch, and guarded by rigidly disciplined soldiers. Did this mean, English observers asked, that Prussians had been enslaved?

\section{ENGLISH FREEDOM AND PRUSSIAN SLAVERY}

At a fundamental level, many of the authors framed their comments on English and Prussian society in terms of slavery. They returned to the belief that Frederick's Prussians were ruled by a tyrant, or even that Prussians were enslaved to tyranny. Edmund Burke railed against "slavery" during the parliamentary debates on the American Crisis in 1775. "Slavery...is a weed that grows in every soil. They may have it from Spain, they may have it from Prussia."140 English travelers often connected Prussian discipline to the unfree and "slavish" nature of Prussian society. Claims that the Prussian system reduced its people to slaves were not new in Frederick II's time, but also existed under his father, Frederick II. Éléazar de Mauvillon, in many ways the original commentator on Prussian society, noted that Frederick William I "certainly never intended that Officers should treat his Subjects like Slaves." ${ }^{141}$ Thus, Mauvillon not only asserted that conditions in Prussia were harsh, but also that soldiers treated civilians with disdain. Military observers thoroughly debated claims like those of Edmund Burke and Éléazar de Mauvillon in their quest to understand England and Prussia.

Dr. John Moore, perhaps the harshest critic of Prussian military discipline, invoked orientalism in his comment on the treatment of Prussian common soldiers:

The common state of slavery in Asia, or that to which people of civil professions in the most despotic countries are subject, is freedom in comparison of this kind of military slavery. The former are not continually under the eyes of their tyrants, but for long intervals of time may enjoy life without restraint, and as their taste

\footnotetext{
${ }^{140}$ Proceedings of the House of Commons, "Speech on Moving Resolutions for Conciliation with America, 22 March 1775"

${ }^{141}$ Éléazar de Mauvillon, The History of Prussia, Particularly During the Reign of the Late King Frederick William, (London: R. Manby, 1756) 137.
} 
dictates; but all the foreign soldiers in this service... are always under the eye of some body, who has the power, and too often the inclination, to control every action of their bodies. ${ }^{142}$

Moore, not content to discuss Prussia in terms of slavery, also applied it to peasants living in the Austrian Empire. ${ }^{143}$ Many other English authors confirmed this viewpoint. Even Robert Jackson, an author who would eventually conclude that nativist motivation rather than harsh discipline propelled the Prussian Army, noted that "the Prussian system...operate[s] upon the sensibilities of man, as upon the senses of a slavish animal." ${ }^{144}$ American Colonel Smith noted that in Central Europe, "there are but two degrees, the noble and the peasant — the master and slave - under these circumstances to the traveler the general appearance must be wretched." ${ }^{145}$ Smith also referred to soldiers as, "slaves of power cloathed in militaryuniform." 146

Military-intellectual travelogue authors fiercely debated the nature of rule under Frederick II of Prussia despite his celebrity status. John Moore created something of a stir when he suggested that Frederick II cared for his peasants primarily as a way of strengthening his manpower. "The spirit of the government is not favourable to great and independent Lords," he wrote. "But both the great and the small landlords are prevented from squeezing or oppressing the peasants. ${ }^{1177}$ While to the modern mind, this might seem like a positive thing, Moore quickly explained why he thought Frederick favored peasants over the ruling class: "As the soldiery are drawn from them, care is taken that they shall not be deprived of the chief source of health and

\footnotetext{
${ }^{142}$ John Moore, A View of Society and Manners in France, Switzerland, and Germany, 2:156.

${ }^{143}$ Ibid, 337.

${ }^{144}$ Jackson, A Systematic View of the Formation, Discipline, and Economy of Armies, 70.

${ }^{145}$ Miranda, Archivo del General Miranda, 1:377.

146 Ibid, 419.

${ }^{147}$ Moore, A View of Society and Manners in France, Switzerland, and Germany, 2:207.
} 
vigour." ${ }^{148}$ Thus, the good health and care taken for Prussian peasants, in Moore's view, was only to further the military machine of Prussia.

Writers from Central Europe wasted no time in defending the king of Prussia, and taking their own swipes at English institutions. Even writers from states hostile to Prussia defended its institutions from this English outsider. Johann Kaspar Reisbeck, a Viennese author and friend of Austrian state minister Kaunitz, replied extensively to Moore in his 1783 travelogue: "Dr. Moore thinks that the king of Prussia's reason for contributing so much to the prosperity of his farmers is that they may supply him with soldiers. None but an Englishman, who is used to distort everything to the opinion which best suits his prejudices, could have had such an idea." 149 Reisbeck, though an Austrian, defended Prussia extensively: "Hardly two-fifths of the Prussian army consist of farmers' sons; above half are foreigners, and the other half is made up equally from town and country. ${ }^{, 150}$ Not content to merely praise the Prussian model, Reisbeck began to launch a spirited attack against the English institutions: "The king of Prussia...far differently from the English legislature, considers the peasants as the most useful members of the community. He does not trouble himself with foreign colonies[.] ${ }^{, 151}$ For Reisbeck, English grandees used the people of their country for their own glorification:

Blinded by a false appearance of freedom, the English farmer thinks that he is fighting for the good of his country, whilst in fact he is fighting to support the vices of the great. The true meaning of this is, that the nation would have soldiers and sailors to fight through storms and batteries for a freedom which hardly a twentieth part of the nation possesses. ${ }^{152}$

\footnotetext{
${ }^{148}$ Ibid.

${ }^{149}$ Reisbeck, Briefe eines reisenden Franzosen, 2:98.

${ }^{150}$ Ibid, 99.

${ }^{151}$ Ibid.

${ }^{152}$ Ibid, 98.
} 
Reisbeck's argument sounds almost proto-Marxist in its formulation, but in actual fact it arose out of beliefs regarding the moral economy in the eighteenth century. ${ }^{153}$ As E.P. Thompson has discussed, food prices and availability were points of contention, controlled against the will of common people. Both Reisbeck and Moore discuss the nature of grain and corn prices, and it is likely Reisbeck had this type of incident in mind when he mentioned "the vices of the great." He particularly refuted the claim that the Prussian government was obscurantist, claiming that "some Englishmen, who think that the essence of liberty consists in babbling, and giving vent in parliament to every species of ill-humour; and, who from their impudence and self-sufficiency, are the worst observers that travel, have most probably spread this opinion." ${ }^{154}$ Reisbeck, clearly, was not afraid to return English criticisms of Prussia with interest. He defended the system of agriculture in Prussia, and particularly the tax-system of Frederick II:

The great advantage which the Prussian farmer has over the English, that which renders him, without a doubt, the freest and happiest farmer upon earth, is, that his land-tax is never increased; this circumstance alone would be sufficient to silence all the clamours raised about Prussian despotism, were the persons who raise them capable of any shame, or did they take any trouble to see more of the country than it is possible they should see by riding post through it. ${ }^{155}$

In this remarkable passage, Reisbeck takes the English travelogue authors to task for not spending sufficient time in Prussia, having no shame, and for misunderstanding Prussian society in the late eighteenth century. Reisbeck, not content to merely defend the system of the king of Prussia, wrote extensively against the English system of government, suggesting that poor people of England were reduced to "slavery,"

\footnotetext{
${ }^{153}$ E. P. Thompson, "The Moral Economy of the English Crowd in the Eighteenth Century." Past \& Present, no. 50 (1971): 76-136.

${ }^{154}$ Reisbeck, Briefe eines reisenden Franzosen, 2:88.

${ }^{155}$ Ibid, 98.
} 
In the present state of things in England, the farmer has evidently no mare in the legislation; he is in the strongest sense of the word, a slave of a superior order. $\mathrm{He}$ is compelled to go as a soldier or sailor to America, or the East or West Indies, and the highest and less numerous class of the people enjoy the fruits of his labours. ${ }^{156}$

If Prussian society were highly subordinated, Riesbeck argues, English society was simply enslaved to an aristocracy of money. Here, Riesbeck takes the idea of the English as a polite and commercial people, and asserts that commerce has caused a lack of freedom for poor Englishmen.

Despite throwing around the term slavery with incredible freedom, almost none of the authors alluded to African slavery, which existed throughout the British Empire, and in a small degree, in Prussia. ${ }^{157}$ European armies widely employed both free and unfree Africans as musicians who became status symbols in the eighteenth century. These armies attempted to emulate Ottoman military bands, and Africans played a large role in the construction of a transplanted Ottoman-style military musical culture. Despite this fact, very few contemporary authors commented on these men, or used slavery as a term to compare the experience of white and black men in the British Empire. One of the few to do so was Jeffery Foote, an advocate for the continuation of African slavery, who explicitly compared the case of European soldiers to African slaves in his 1792 volume A Defence of the Planters of the West Indies. Foote believed that "whether a negro slave or a Russian slave, a Prussian soldier or an Ansbacher... a peasant or a collier-provided their wants be supplied and they cheerfully pursue their occupations, it would be vain in reformation to grant them more." ${ }^{\prime 158}$ Most military accounts were completely silent on

\footnotetext{
${ }^{156}$ Ibid, 96.

${ }^{157}$ Rebecca von Mallinckrodt, "There Are No Slaves in Prussia?" In Slavery Hinterland: Transatlantic Slavery and Continental Europe, 1680-1850, edited by Brahm Felix and Rosenhaft Eve, by Bredeck Elizabeth, 109-32. Woodbridge, Suffolk, UK; Rochester, NY, USA: Boydell and Brewer, 2016.

${ }^{158}$ Jeffrey Foote, A Defence of the Planters of the West-Indies, (London: J. Debrett, 1792) 28.
} 
the evils of African slavery, despite the fact that almost all of the militaries of Europe included small numbers of black soldiers.

Despite the repeated comments regarding Prussian slavery, most travelogues noted that Prussian peasants were materially affluent compared with the other states of Europe. John Moore found that "there is no peasantry in Europe better fed than the Prussian." ${ }^{\prime 59}$ Travelling through the country around Magdeburg in 1774, David Scott saw "the country more fertile, some woods, [and] a great many villages, so that this part of the country must be well peopled, the houses and every thing done neatly up, and all the appearance of Industry." ${ }^{\prime 60}$ Reisbeck argued that this prosperity was due to the king of Prussia. Reisbeck indicated, "He not only gives those who are inclined to improve the waste lands, wood for building, cattle, and stock of all kinds, but lays out large sums of money amongst the poor farmers." ${ }^{161}$ Writer Joseph Marshall noted that upon crossing into Silesia from Poland, "the land [is] all cultivated, and much of it extremely well ; the houses and cottages in good repair ; with all the appearances of ease and happiness." ${ }^{\prime 162}$ Only the American Colonel Smith refused to recognize the prosperous comfort of ordinary Prussians:

the distress that this system of despotism produces, shews itself in every village, and the king possessing almost all the wealth of the country, keeps his subjects almost totally dependent on himself for a subsistence - he is constantly building new houses and superficially improving his capital and country villa and other places, he thus keeps his subjects constantly employed at a very cheap rate. ${ }^{163}$

We can only imagine Johann Kaspar Reisbeck's nearly apoplectic response to this.

As they examined Prussian wealth and demography, English authors also found the population and demographic policies of Frederick II foreign. David Scott, who accompanied

\footnotetext{
${ }^{159}$ Moore, A View of Society and Manners in France, Switzerland, and Germany, 2:207.

${ }^{160}$ Bodleian Library, MS Eng. Hist. C 282, "Narrative of General Conway's Tour”, 31.

${ }^{161}$ Reisbeck, Briefe eines reisenden Franzosen, 2: 98.

162 Joseph Marshall, Travels through Holland, Flanders, Germany, (London: J. Almon, 1772) 3:269.

${ }^{163}$ Miranda, Archivo del General Miranda, 1:377.
} 
British General Conway during his tour of Europe in 1774, also attempted to discern Frederick of Prussia's reason for treating the common people of his kingdom with care. According to Scott, Frederick wanted to increase the number of people living in his realm, "giving them all the greatest encouragement which I am told answered his expectations in peopling parts of the country with peasants." ${ }^{164}$ In Frederick's mind, more peasants meant a larger tax base, and more recruits for Prussia's future conflicts. In 1785 American Colonel Williams Stephens Smith also noticed this tendency to grow the population on the part of the Frederick: "the king, under the idea of encouraging population, is the avowed protector of prostitutes of every descriptionwhen any of the common women prove with child, they are received and maintained at the infirmary until they are delivered and recover." ${ }^{165}$ Smith was further horrified that "a parent is severely punished if he treats a daughter with the least insult on her proving with child...or make use of any language to insult, ... on the slightest complaint to the governor or magistrate, the girl is protected and the parent or master punished." ${ }^{166}$ As an American, Smith was understandably scandalized that natal care would be provided by the state and that women would not be punished for reproducing out of wedlock. It will come as no surprise, then, that despite corresponding with his future wife, Abigail Adams, Smith had an encounter in Prussia which "increased my attachment to the fair sex," and he noted with delight that, "the women in general are neglected by the men so that a foreigner of any gallantry is well received." ${ }^{167}$ Such was the loyalty of John and Abigail Adams' future son-in-law.

Some Prussian travelers, particularly travelers with an intellectual bent, seemed to agree with the charges of political backwardness leveled against Prussia by the English travelogues.

\footnotetext{
${ }^{164}$ Bodleian Library, MS Eng. Hist. C 282, "Narrative of General Conway’s Tour" 41.

${ }^{165}$ Miranda, Archivo del General Miranda, 1:393.

${ }^{166}$ Ibid.

${ }^{167}$ Ibid, 394.
} 
Karl Phillip Moritz noted while travelling in England that "an English man...has his rights and privileges defined and known as exactly and as well as his king, or as his king's minister- take my word for it, you will feel yourself very differently affected from what you are, when staring at our soldiers in their exercises at Berlin." ${ }^{168}$ Englishmen, by the freedom of expression they possessed, seemed to Moritz to have greater political opinions. Freiherr de Pollnitz, observing London in the 1730s, described it as "that City, which for its Extent, the Number of its Inhabitants, and their Wealth, may pass, not only for the Capital of a powerful Kingdom, but even for the Capital of Europe: That City, where True Liberty bears Rule."169 A few Prussian authors, in observing the political differences between the two cultures, were not afraid to admit that Englishmen lived in a more open and democratic society.

Though no believer in English liberty, perhaps unsurprisingly, American Colonel Smith complained the loudest regarding the tyranny of Prussia. On observing the Prussian palace at Sanssouci, he admitted that "notwithstanding all this tyranny and oppression, [Frederick] travels unattended, his palace is not like others surrounded with guards and walls, but is open to the country[.]"170 The lot of prisoners of the state captured Smith's attention even more strongly:

we met on the bridge a guard of soldiers with a number of distressed objects in rags in the centre all chained and rattling thro' the streets, going to this dungeon after their dayly labour-here are lessons for Republicans and subjects for the advocates of despotism to blush at the sentinel on his post, high plumed and ready for heroic deeds, with an hungry countenance, will beg your charity- if he is detected in this he is punished-- they have others modes of salutation than the ordinary beggar. ${ }^{171}$

\footnotetext{
168 Moritz, Reisen eines Deutschen, 61.

${ }^{169}$ Karl Ludwig Pollnitz, Memoirs of Charles Louis, Baron de Pollnitz, (London: Daniel Browne, 1737) 3:431.

${ }^{170}$ Miranda, Archivo del General Miranda, 1: 377.

${ }^{171}$ Ibid, 373.
} 
Smith returned to this theme of tyranny again and again, often noting how badly soldiers were paid. Smith does not address the practice of allowing soldiers to take trades (Freiwachter), nor does he comment on the practice of allowing cantonists to return home for nine months of the year, and it is possible that he was not aware of it. Smith, like many other Anglophone authors, remained fascinated by the stereotyping of the unfree Prussian other.

While this particular argument broke down along the lines of regional differences, it is important to keep in mind the opinions of Karl Phillip Moritz and David Dundas, who both saw much to admire in opposing society. Aspects of their respective cultures horrified both Britons and Prussians, but they also found much to admire about their respective societies. Opinions about the Prussian and English Other were not merely negative, but often nuanced, as English and Prussians attempted to identify both strengths and weaknesses in the social fabric of their worlds.

\section{CONCLUSION}

The last of the truly eighteenth-century travelogues was written at the turn of the nineteenth century by John Quincy Adams, the American minister to Prussia and brother-in-law of Colonel William Stephens Smith. It contains almost all of the same themes which unite the travelogues that have been discussed in this chapter. The yearly seasonal cycle of cantonists returning home was observed: "The service of these soldiers in time of peace is required only during three months in the year, when they are assiduously trained and exercised, and which close with the month of August[.]"172 Despite the fact that Frederick II had been dead for fifteen years, he was still compared favorably with his successors: "the king reviews them at Neiss and

\footnotetext{
172 John Quincy Adams, Letters on Silesia: Written During a Tour Through that Country, (London: J Budd, 1804)
} 333. 
Breslau. This Frederick II never failed to do. His successors have frequently omitted it, and the last summer was the first instance of it under the present reign." ${ }^{173}$ As a freeborn American, he described his revulsion at the experience of "being accosted at the entrance of every town, by a man with his musket and bayonet in the hand, and that hardly civil question of, 'Who are you?", 174 John Moore and David Scott experienced this same revulsion at the regulation of the urban-rural boundary by fortifications twenty-five years earlier.

Perhaps more importantly, John Quincy Adams noted that there were Prussians who disagreed with his sentiments. If he identified the towns without garrisons as the most free, a Prussian author he had read "alleges arguments to prove... that the garrisons in the towns, of course, put in circulation a quantity of money, afford subsistence to tradesmen of all descriptions, and furnish a market for the produce of the farmer." ${ }^{175}$ This Prussian author continued: "The military service habituates the peasant youth to principles of order and the practice of cleanliness, which they [the soldiers] communicate...among their neighbours, upon returning to reside among them." $" 176$ John Quincy Adams formed opinions regarding the Prussian military, state and society as a result of his worldview, and those opinions were contested by another intellectual, continuing the stereotypical debate regarding militarism we have observed throughout the second half of the eighteenth century.

This chapter has argued that between 1739 and 1789 both military and civilian observers developed martial stereotypes regarding the military states of Britain and Prussia during their travels. These stereotypical observations were then published for consumption by the military public sphere. These men often commented widely on the societies they encountered, not merely

\footnotetext{
${ }^{173}$ Ibid

${ }^{174}$ Ibid, 201.

175 Ibid, 334.

176 Ibid.
} 
writing specialist military treatises designed to create military reform. Taken together, these travelogues represent the diverse perspectives of military and civilian observers of two mideighteenth century states. Between 1739 and 1789, the military worlds of Prussia and England were not merely connected by alliance systems and political necessity, but by the writings of militarily-inclined travelers. Although the travelers debated the merits of their militarycelebrities, they also turned to questions which historians continue to debate today: what was the nature of military-civilian interaction, what motivated men to fight, and how free or unfree were the societies they encountered. On the both the English and Prussian side of these narratives, they demonstrate a keen interest in the military and its relation to society which makes ideas of the Old Regime appear dynamic and in conversation with one another, rather than strictly subordinated to monarchical control.

These men who reinforced existing stereotypes had a long-lasting historiographic impact. Historians working in the nineteenth century took some famous examples of this writing to argue that English freedom and Prussian slavery were real concepts, made possible by the militarism, or lack thereof, present in these states. Obviously, these two states contained enormous geographic, governmental, and societal differences. The histories of the development of constitutional parliamentary rule and monarchical absolutism are not the same histories. With that said, military men often found much in between the two states that was mutually intelligible. Some of these same men extolled the virtues of military and societal organization in the other state, and their voices were often conveniently lost in the creation of the narratives of militarism, freedom, and slavery. Observers recognized that state militaries were only as strong or weak as the societies that produced the soldiers. These reformers realized that military life in the two states was distinct, but that there were similarities, and even lessons to be learned, in how these 
two military societies utilized local connections. As these travelers made notes on the societies they encountered, a different sort of connection was taking place, as the common soldiers who composed the armies of Britain and Prussia carried on a long-distance communication with their families and communities. Having examined the opinions of military observers on common soldiers and the armies they made up, the next chapter turns to the letters of the soldiers themselves, how those letters connected not just individuals but whole communities, and how those communal bonds impacted the military and civilian worlds. 
"Writte to me as before and let me know the news in the Town"

\section{Soldiers' Families, Local Identity, and Their Letters}

In March of 1778, soldier William Calder of the Third Regiment of Foot Guards wrote home to his uncle, aunt, and cousins about town life in London and his experiences in the military. What is astonishing about Calder's letter, and the letters of so many eighteenth-century soldiers, is the great variety of messages, from many soldiers to various recipients, in the body of these letters. In London, Calder wrote greetings from Mr. Reid, a family friend, Mr. Harper, "our old neighbor", and other individual soldiers. Calder informed his uncle, "You may tell Henry Bowey his brother is well alive, I mean I enlisted him in Edinburgh, he is in the Company with me and behaves very well." In the course of their military service, eighteenth-century soldiers from Prussia and the British isles experienced separation and isolation from their families and village communities.

This separation became more bearable when soldiers could maintain a written correspondence with their loved ones. Not all soldiers could read or write, but most soldiers knew a literate man in their company or regiment, frequently from the same locale, who could include a message home for them. Letter-writing soldiers maintained close correspondence with their own families, but also provided a means of keeping the entire community connected during times of military service. Soldiers deliberately sought out members of their local community who were present near them, and in some eighteenth-century armies, were assisted in this process via state-controlled methods for local recruitment of soldiers. Eighteenth-century soldiers used the facility of letters to keep the village community alive, preserving their kinship ties and local

\footnotetext{
${ }^{1}$ National Army Museum, London (NAM) 1986-11-1
} 
connections, and creating a sense of community within their regiments. Calder closed his letter, "Writte to me as before and lett me know the news in the town[.]"2

This chapter examines the world of soldiers' letters in the second half of the eighteenth century. In it, I argue that in some armies, such as the Prussian army, and the Jacobite Army of 1745, soldiers maintained close ties to their village communities, as soldiers in other armies failed to maintain a firm local identity. Second, I argue that in their letters these soldiers often emphasized their relationship to civilian family members in their writing, and frequently showed an interest in communal life beyond family ties. Third, and finally, I argue that this adds complexity to the idea that soldiers became clearly distinct and even hostile to civilians in their own states during the eighteenth century. Unknown "friendly" civilians whom soldiers encountered during their service did not enjoy the same level of respect as the families and communities from which they were drawn. This formulation challenges the scholarly view that soldiers militarized their societies, and that they formed a completely distinct soldierly identity in the eighteenth century. ${ }^{3}$

During the eighteenth century, soldiers distinguished themselves increasingly from civilians. Colored woolen uniforms set them apart from civilians, and as Ilya Berkovich has demonstrated, a military mindset began to take hold among these men. The broad outlines of Berkovich's argument are sound but not accurate in all armies, soldiers, and states. In contrast, my research demonstrates that the soldiers remained deeply connected to their civilian village worlds during the eighteenth century. Between 1739 and 1789, soldiers wrote to their families,

\footnotetext{
${ }^{2}$ Ibid.

${ }^{3}$ Otto Büsch, Militärsystem und Sozialleben im alten Preußen: Die Anfänge der sozialen Militarisierung der preußisch-deutschen Gesellschaft, 1713-1807,(Berlin: Walter de Gruyter, 1962), Ilya Berkovich, Motivation in War: The Experience of Common Soldiers in Old-Regime Europe, (Cambridge: Cambridge University Press: 2017).
} 
acquaintances, social superiors, and patrons. These letters connected military men with the civilian communities they had left behind, and provided a vital link between families separated by war. Previous eighteenth-century specialists who have addressed these letters have primarily used them as a way of gauging literacy among common soldiers. Such estimations of literacy are valuable, yet this chapter primarily examines the process and experience of communication between common soldiers and their correspondents.

The chapter gathers data from over 150 letters from eighteenth-century soldiers, primarily those serving in the Prussian Army and from the British Isles between 1739 and 1789. The process of collecting these letters was both easy and, at the same time, challenging. Some of them come from long published sources, such as Curt Jany's Urkundliche Beiträge und Forschungen zur Geschichte des Preussischen heeres. Others are located in relatively large collections of captured correspondence; still more are located singly, or by ones and twos, in small archives across Europe and North America. It is vital to understand at the outset that these two hundred-odd letters are not a statistically significant sample of all letters written by eighteenth-century soldiers between 1739 and 1789 . With that being said, this is the largest sample of letters collected by any historian of this era to date. As a result, it must serve as our sample, however imperfectly.

As a source base, letters provide a different window into the military experience compared to other sources. Unlike the authors of memoirs, letter writers did not always survive the military conflicts in which they participated. As a result, we often find that a letter collection ends with a death notice, or letter from a family member asking military authorities why letters from their soldier have stopped. Letters also provide a window into soldiers' experiences chronologically close to the events under description. Memoir authors often felt the need to 
respond to contemporary events: events which occurred long after the historical narrative described in their memoirs. By their need to maintain a narrative structure, memoirists often excluded certain memories which did not fit into their narrative. Letters often referred to hardship, suffering, loss, and other human experiences which memoirs sometimes excluded. I do not believe that letters provide a better or perfect window into history, simply that they provide a different view than studies which rely primarily on memoirs.

In the eighteenth century, Prussian soldiers were brought into the army in a variety of ways. These troops were divided into two broad categories: native cantonists and foreign recruits. Both groups contained men who were recruited willingly and unwillingly, or 'dragooned' to use a popular turn of phrase. When possible, I attempt to identify soldiers through these categories. It should be noted, however, that especially after the Seven Years War, these categories were malleable, and many native Prussian volunteers were listed as "foreigner" on muster rolls, to avoid mixing them with cantonists. The peculiarities of the canton system itself were sufficiently distinctive to merit an examination of Prussian soldiers in isolation from the rest of Europe. In English, the best description of the operation and effects of the canton system is still the translation of Otto Büsch's monograph on the militarization of Prussia in the eighteenth century. ${ }^{4}$

This chapter intersects with a number of historiographies and is deeply indebted, in terms of methodology, to Alan Forrest's Napoleon's Men. Forrest explores letter writing as a form of

\footnotetext{
${ }^{4}$ In English translation: Otto Büsch, Military System and Social Life in Old Regime Prussia, 1713 - 1807 the Beginnings of the Social Militarization of Prusso-German Society, trans. John G. Gagliardo (Boston: Humanities Press, 1997), for German readers, see Martin Winter, Untertanengeist durch Militärpflict: Das Preussische Kantonsystem in brandenburgischen Städten im 18. Jahrhundert, (Bielefeld: Regionalegeschichte, 2005).
} 
public documentation. ${ }^{5}$ Using the medium of letters, Forrest explored the daily lives and relationships of common soldiers in Napoleon's military force, by examining correspondence between soldiers and their families. In much the same vein for this earlier period, my research reveals that the letters of Prussian soldiers between 1739 and 1789 were not private documents, but a way for village communities to stay in touch, and even a way for men to retain local identities while serving with the army. As we will see, letter writing was a practice that brought Prussian villagers together, both at home and with the army. What place, then, did eighteenthcentury common soldiers hold within the hierarchy of European states? In many ways, this research is a response to E.P. Thompson's call in The Making of the English Working Class: "We need more studies of the social attitudes of criminals, of soldiers and sailors, of tavern life." 6 While differing from Thompson in many respects, the project attempts to answer this call, and is in part an effort to reconstruct what Thompson calls "social attitudes" or what might be called the "worldview" of soldiers. Indeed, much evidence has been presented that European soldiers had an attachment to their armies. In the course of the eighteenth century, British, American, Hessian, Saxon, and Prussian soldiers all resisted opportunities to enlist in opposing armies, and instead escaped back to their native armies in large numbers. Recent research from scholars such as Berkovich has done much to suggest that eighteenth-century common soldiers were hardly the put-upon "dregs of society" that twentieth-century scholars often identified. Rather, these Prussian soldiers often viewed their service as honorable. ${ }^{7}$

\footnotetext{
${ }^{5}$ Alan Forrest, Napoleon's Men: The Soldiers of the Revolution and Empire, (New York: Continuum International Publishing, 2006) xii-xiii, 27-29.

${ }^{6}$ E. P. Thompson, The Making of the English Working Class (New York: Pantheon Books, 1964), 59.

${ }^{7}$ Berkovich, Motivation in War, 14-16. Marcus von Salisch, Treue Deserteure: Das Kursächsische Militär Und Der Siebenjährige Krieg (München: R. Oldenbourg, 2009).
} 


\section{VILLAGE LIFE}

In Prussia, an average of seven villages in the Brandenburg district Stavenow at the turn of the eighteenth century gives a mean of 24 households, with a median and mode both of 27 households. ${ }^{8}$ Likewise, in Britain, around the turn of the eighteenth century, perhaps 80 percent of the population lived in rural villages, and although it is almost impossible to estimate the average village size across Britain in the eighteenth century, most villages were in the order of 100 to 400 individuals, with the number of households per settlement apparently slightly larger in Britain than in Prussia. ${ }^{9}$ In both Britain and Prussia, fullholders, or yeoman, households outnumbered smallholders and day-laborers in almost every village. The realities of eighteenthcentury village life, as revealed by recent scholarship, such as the works of William Hagen and Peter Laslett, often challenge longstanding stereotypes regarding the nature of poverty and hardship in these rural worlds.

Households had changed greatly from the medieval house with its one room. Indeed, even the poor peasants of the Büdner class could expect a dwelling with a separate bedroom, living room and kitchen, with separate enclosed rooms for livestock and fodder. ${ }^{10}$ This same process was at work in England, where peasants built larger houses of multiple-purpose rooms, using brick and stone, with boarded floors replacing the earth floors of the seventeenth century. ${ }^{11}$ These household communities, "das ganze Haus," looked slightly different in Britain and

\footnotetext{
${ }^{8}$ William H. Hagen, Ordinary Prussians: Brandbenburg Junkers and Villagers 1500-1840, (Cambridge: Cambridge University Press, 2002) 44-60.

${ }_{9}^{9}$ Peter Laslett, The World We have Lost: Further Explored,(London, Routledge, 2004), 52-58.

${ }^{10}$ Geheimes Staatsarchiv Preußischer Kulturbesitz, (GStaPK) Hauptabteilung (HA) X, Rep. 37 Stavenow, Nr.688.

${ }^{11}$ G.E. Mingay, English Landed Society in the Eighteenth Century, (London: Routledge, 1963), 233-235.
} 
Prussia. In Prussia, larger multi-generational households seem to have endured to a greater extent than in Britain, where the average household size was approximately four. ${ }^{12}$

In the second third of the eighteenth century villagers in both Britain and Prussia lived lives that were marked by greater material wealth than previous generations, and possessed a limited surplus. ${ }^{13}$ Despite this, life expectancy was lower than modern norms, daily work was hard, and in both Britain and Prussia the state intervened to curb the worst of poverty's effects during the century. ${ }^{14}$ Though they were poor, peasants often possessed multiple suits of clothes, and depending on their particular status, often had access to livestock. ${ }^{15}$ Families worked hard together to avoid hunger and poverty; indeed, Prussians spoke of their household communities not in terms of family but using terms such as Haushaltung and Wirtschaft. ${ }^{16}$ Despite the economic and labor-orientated nature of these terms, soldiers' letters display a great deal of emotional focus which underlines the importance of the family in their mental worlds.

As this chapter will show, many soldiers wrote to their wives, and it may seem natural to assume that most eighteenth-century soldiers were married. This assumption demonstrates one of the challenges of using letters as a primary source base. From the available period muster rolls of the Austrian, British, and Prussian armies, it appears that an average of 21 percent of soldiers were married during the era under examination. The Austrian Army, though not a central feature of this study, was one of the earlier professionalized armies, and provides a useful baseline of comparison for the British and Prussian experience. Christopher Duffy's lifetime of work in the

\footnotetext{
${ }^{12}$ Hagen, Ordinary Prussians, 124; Laslett, The World We have Lost, 90.

${ }^{13}$ Hagen, Ordinary Prussians, 278-278, Laslett, The World We have Lost, 150.

${ }^{14}$ Hagen, Ordinary Prussians, 262-268.; Takashi Iida, "Coping with Poverty in Rural Brandenburg: The Role of Lords and State in the Late Eighteenth Century." In Public Goods Provision in the Early Modern Economy: Comparative Perspectives from Japan, China, and Europe, edited by Tanimoto Masayuki and Wong R. Bin (Oakland, California: University of California Press, 2019) 118, Roy Porter, English Society in the Eighteenth Century, (London: Pelican Books, 1982) 290-301.

${ }^{15}$ Hagen, Ordinary Prussians, 222-228.

${ }^{16}$ Ibid, 126.
} 
Austrian War Archives has indicated that of the 122,435 soldiers listed in the muster rolls from the Seven Years War era, approximately 14.03 percent were married. Don Hagist has shown that perhaps 17 percent of British soldiers stationed in New York City were listed as having a woman on the establishment of the regiment. ${ }^{17}$ This figure could be higher, as some soldiers might have left their wives at home in Britain. Finally, in the Prussian Army in the period directly after the Seven Years War, Beate Engelen has demonstrated that perhaps 29.65 percent of soldiers in the Berlin and Potsdam garrisons were married. Christopher Duffy, examining just the Potsdam garrison, arrives at a higher figure: 32.2 percent. $^{18}$

These figures, though they come from the period after the Seven Years War, roughly match what historians might expect given the surviving letter recipients from the British and Prussian Armies. As an army which recruited heavily from its own population at differing stages of life, the Prussian Army was more likely to possess married soldiers. Soldiers who were furloughed in their home villages for 9-10 months of the year were also likely to have lives that looked more like their civilian counterparts than soldiers who remained with the military permanently. In the period after the Seven Years War, Frederick II deliberately encouraged common soldiers to marry. Thanks to the movement of Russian and Austrian armies, Prussia had lost some 500,000 of its civilian population in the Seven Years' War. ${ }^{19}$ Frederick II possessed no illusions about the state of Prussia's economy. Taking drastic and severe measures, he forcibly abducted teenagers (both boys and girls) from neighboring states under Prussian control (Saxony

\footnotetext{
${ }^{17}$ Don Hagist, "The Women of the British Army in America," The Brigade Dispatch: The Journal of the Brigade of the American Revolution, Volumes XXIV-XXV.

${ }^{18}$ Beate Engelen, Soldatenfrauen in Preußen: Eine Strukturanalyse der Garnisonsgesellschaft im späten 17. und im 18. Jahrhundert (Lit, 2005), 88-89. Christopher Duffy, The Army of Frederick the Great, ${ }^{\text {nd }}$ Edition (Chicago: Emperor's Press, 1994), 81.

${ }^{19}$ Matt Schumann, "The end of the Seven Years' War in Europe," in Mark Danely and Patrick Speelman, The Seven Years War: Global Views, (Boston: Brill, 2012), 514.
} 
and portions of Poland). ${ }^{20}$ The boys were placed into the army, and the girls were married to Prussian soldiers. This act was understandably later viewed with some embarrassment in Prussia, even if contemporary foreign observers did not find it shocking. Frederick was willing to take whatever steps necessary to rebuild Prussia, regardless of lives affected. In fact, Frederick's political testament of 1768 positively encouraged marriage and procreation as a solution to demographic challenges. Frederick ordered his officers to "grant free permission for all cantonists and native soldiers to marry when they request it. This will populate the country and preserve the stock, which is admirable." ${ }^{21}$ As the letter data demonstrates, marriages grounded men in the world of the civilian population.

While Frederick II firmly agreed with the practice of marriage for soldiers, he preferred his officers remain perpetual bachelors. ${ }^{22}$ Military intellectuals debated this policy in the British Army as well. During the Seven Years War British Army chaplain William Agar published a series of sermons in 1758 , calling for the total number of recognized wives per battalion to be increased to 200 (approximately one-third of the paper strength), and defending the virtues of married soldiers. ${ }^{23}$ For Agar, having more married soldiers would provide a better family support network in the army, and Agar also believed that being married would cause soldiers to fight more effectively. ${ }^{24}$ Although both Frederick II and Agar believed that more soldiers should be married, the simple fact is that married soldiers were a minority in eighteenth-century armies. Our subsequent investigation of letters will show that married soldiers had more of an incentive to write home.

\footnotetext{
${ }^{20}$ Franz A.J. Szabo, The Seven Years War in Europe, 1756-1763 (London: Pearson Longman, 2008$), 423$.

${ }^{21}$ Friedrich II and Gustav Berthold Volz, Die Politischen Testamente Friedrich's Des Großen (Berlin: Hobbing, 1920), 83.

${ }^{22}$ Duffy, Army of Frederick the Great, 81.

${ }^{23}$ William Agar, Military Devotion: or the soldier's duty to God, (London: P. Brindley, 1758) xxix.

${ }^{24}$ Ibid, xxix-Xxx.
} 


\section{PRUSSIAN SOLDIERS' LETTERS}

These soldiers found military life arduous. Despite their pride in their service, Prussian soldiers were not afraid to admit that it was difficult and demanding. After recalling his glorious first night in the Prussian army, where he was feasted by his new comrades, Dreyer somberly noted that "after that, I often had to make do with issued bread and well-water." ${ }^{25}$ Prussians soldiers were subject to harsh military discipline and difficult conditions of service. The Prussian military justice system was designed to enforce officers' control over men, and dissuade soldiers from desertion. In addition, soldiers faced a rigorous and physically demanding term of military service. At the height of the Seven Years War, Prussian generals such as Prinz Henri, Frederick II's brother, drove men to rare feats of endurance, such as a 148-kilometer march over a period of seventy-two hours. While not uncommon in the modern, or even Napoleonic era, these grueling marches were unique in the eighteenth century.

These hardships were easier to bear when soldiers could draw on village connections, both in and out of their regiments. Prussian soldiers formed firm emotional bonds with both place and family in the eighteenth century, as a result of serving away from their local communities. Soldiers expressed emotion about leaving home. When embarking for the outset of the Seven Years War, veteran soldiers wept upon departing from their families: "There were streams of tears on all sides, and many a veteran hussar rubbed his eyes with the back of his hand, after noticing his wife and children in the circle of saddened spectators." ${ }^{26}$ A private in the Itzenplitz regiment recalled, "Now the drums beat the march, and there were streams of tears

\footnotetext{
${ }^{25}$ Jospeh Ferdinand Dreyer, Leben Und Taten eines Preussischen Regiments-Tambours von ihm selbst beschrieben in seinem 93ten Lebenjahre, Altpreussischer Komimiss 22, (Osnabrück: Biblio, 1975 [1810]), 14.

${ }^{26}$ J. G. Lojewsky, Selbstbiographie Des Husaren-Obersten Von... Ly; Oder, Meine Militairische Laufbahn Im Dienste Friedrichs Des Einzigen (Leipzig: C.Y. Kollmann, 1843), 9.
} 
from citizens, soldiers wives, whores, etc. Likewise the native soldiers of the country who were leaving their wives and children behind, were cast down, full of grief and sorrow." ${ }^{27}$ Returning from abroad with a recruiting party in 1755 , a potential recruit for the Prussian army recalled that upon crossing the Elbe, "the sergeants expressed great joy, because we now walked on the soil of Brandenburg." ${ }^{28}$ Heavily connected to the civilian world, soldiers experienced separation from their homes and families which caused them pain as they left to join the royal army.

Of these local connections, the most important were undoubtedly familial ties. Of the seventy-eight known surviving letters from eighteenth-century Prussian soldiers, over seventy of them are addressed to family. ${ }^{29}$ The letter greetings usually address the letter primarily to one person, and then include a number of other recipients. The data collected from these letters are reproduced in Figures 1 and 2.

\footnotetext{
${ }^{27}$ Ulrich Bräker, Lebensgeschichte Und Natürliche Abentheuer Eines Armen Mannes Von Tockenburg (Zurich: Hans Heinrich Füssli, 1789), 138.

${ }^{28}$ Bräker, Lebensgeschichte, 113.

${ }^{29}$ These letters are drawn from the following sources: GStAPK, HA X, Rep. 37, Stavenow, Nr. 496; HHStAW, Fonds 133, No. 11670; HStAD, G 28, F 2017; Johann Jakob Dominicus, eds. Kerler, Aus dem Siebenjährigen Krieg. Tagebuch des preußischen Musketiers Dominicus, (Munich, C.B. Beck'sche Verlag, 1891) 61-6; Georg Liebe Preußische Soldatenbriefe aus dem Gebiet der Provinz Sachsen im 18. Jahrhundert, (Halle/Salle: Gebauer Schwetschke, 1912) passim; Christian F. Zander, Fundstücke - Dokumente Und Briefe Einer Preußischen Bauernfamilie: (1747 - 1953) (Hamburg: Kovacİ, 2015) 21-82; Curt Jany, "Briefe Preussischer Soldaten aus den Feldzügen 1756 und 1757 und über die Schlachten bei Lobositz und Prag," Urkundliche Beiträge Und Forschungen Zur Geschichte Des Preussischen Heeres. (Berlin: E.S. Mittler, 1901) 1-59; Rolf Dieter Kohl, "Ein Brief des Wiblingwerder Bauernshones Johann Hermann Dresel aus dem Siebenjährigen Krieg, Die Märker, Vol. 28, No. 3 (1979) 82-4.
} 


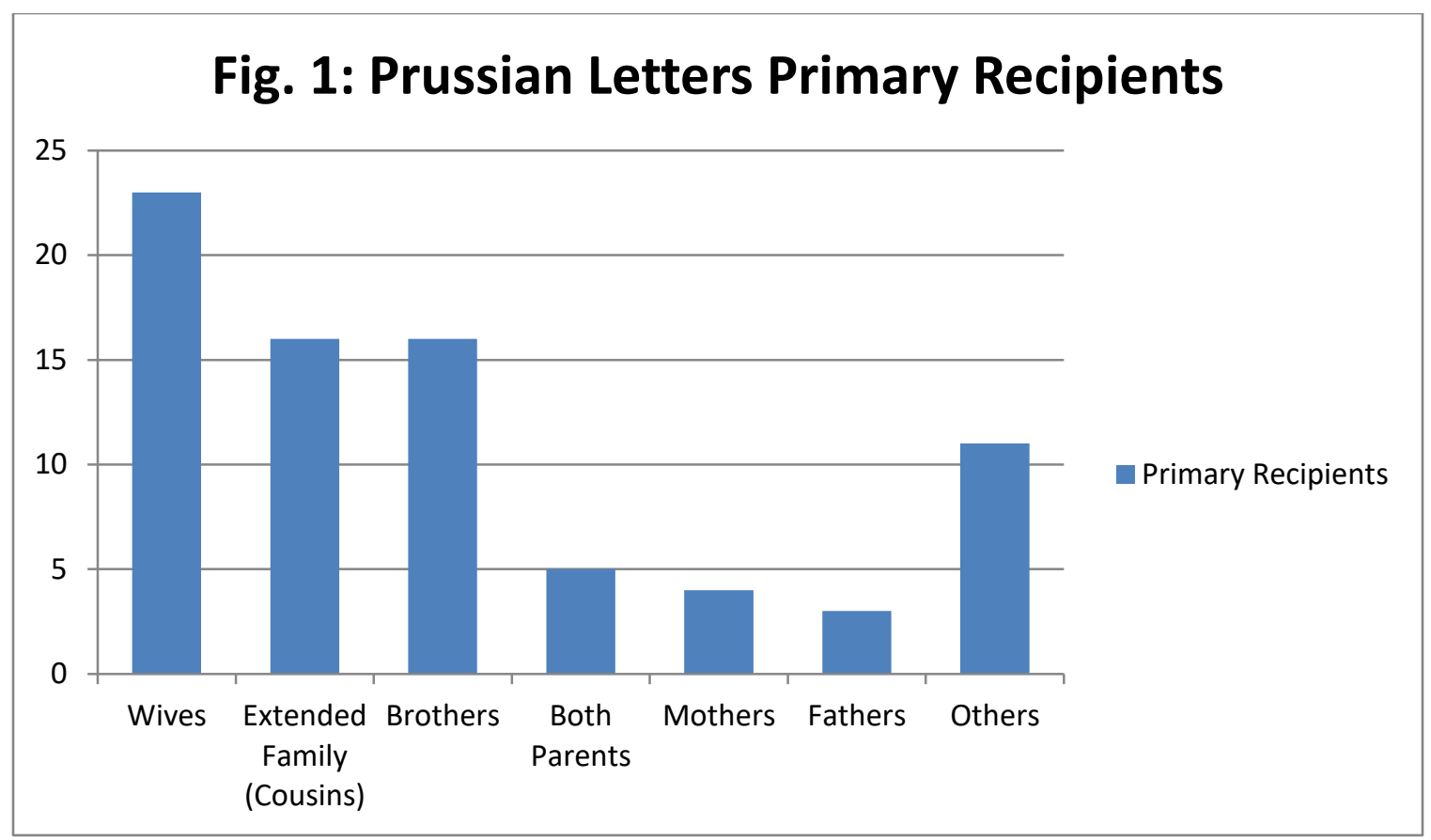

The most surprising, and misleading, aspect of this data is the high proportion of letters to cousins. If the correspondence of Christian Friedrich Zander with this extended family in the village of Nitzan is disregarded, the proportion of letters addressed primarily to more distant relatives drops to a similar number as letters to parents. The data, however, make one issue abundantly clear: Prussian soldiers whose letters survive corresponded with their wives more than any other group, by a wide margin. Although soldier's wives managed economic affairs in their absence, pecuniary details fill a rather small proportion of these letters. Rather, the letters are often filled with tender anecdotes, and are signed with sentiments such as, "I remain your faithful husband." ${ }^{30}$ These greetings clearly indicate that Prussian soldiers possessed emotional lives, and that they remained connected to their family and local identities.

\footnotetext{
${ }^{30}$ Hans Bleckwenn, Preussische Soldatenbriefe (Osnabrück: Biblio Verlag, 1982), 15.
} 


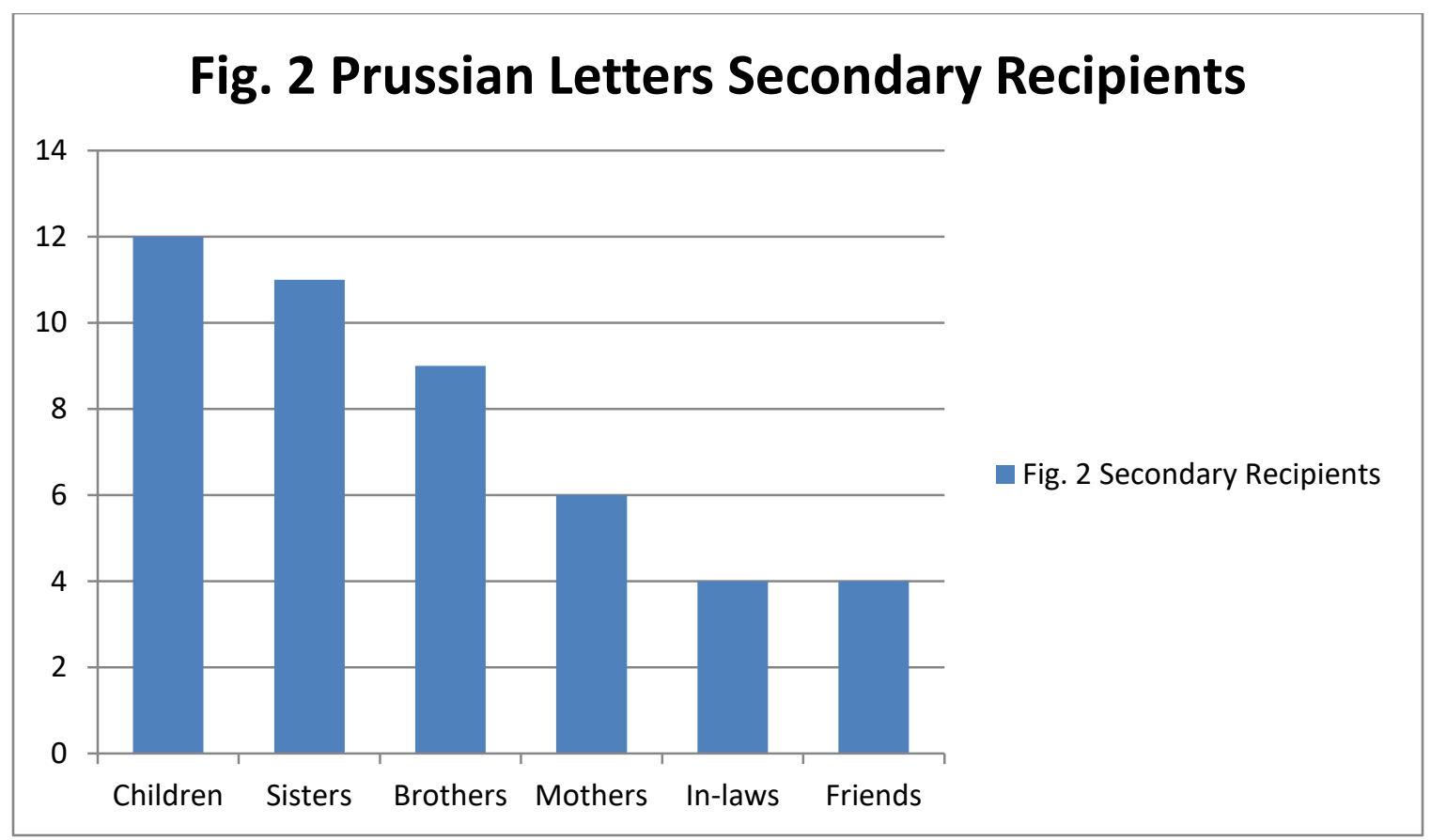

Children, sisters and mothers were frequently mentioned in letter address lines, but rarely as the primary recipient possibly as a result of their status as dependents. Brothers and mothers can be found in both primary and secondary recipient lists, both of which might reflect their ability to transcend the dependent position. Mothers could become important figures when fathers died, and brothers would merit a letter addressed directly to them. When mothers were listed in a secondary status, they were almost always subordinate to either wives or fathers. Finally, in-laws were occasionally mentioned, but remain the smallest group of family relations present in Prussian soldier's letters. A few soldiers also greeted non-relations in their address lines, always in a secondary status, and both friends and acquaintances are listed, indicating that these letters, far from being private, took on village-wide importance.

For eighteenth-century soldiers, letters home became communal documents, designed to connect many soldiers both to individual families and to their home villages. The first way in which these letters are communal is literal: Prussian soldiers' letters often contain more than one 
voice. Messages from other authors frequently appear as postscript or notation in the margins of eighteenth-century soldiers' letters. Sometimes, these are messages written by the author of the main letter, other times, they appear as new voices written in a different hand. In his letter home on November 24, 1756, Christian Friedrich Zander added a post-script: "P.S. Jochen Müller, Weidemann, Andreas Backe, and Börnicke are all still healthy and send many greetings home. Valtin Bährend is with the Regimental Surgeon, and the entire army says hello. Please write to us again! Farewell. ${ }^{\text {"11 }}$ Christian Zander's greeting, "the entire army says hello," does much to capture the spirit of these letters home. In the same letter, written by Christian Zander to his family in Nitzahn, a note in the margins informs the reader, "We also greet old H. Wilbergen, and if he is still healthy, we can't wait to see him in the flesh when we return home." ${ }^{32}$ Rather than private documents designed for a single reader, these letters became lifelines between groups of soldiers from the same village and their local communities. Often these marginal notes contain pleas for return letters, some as simple as, "write us soon!" Both Johann and Christian Zander scribble marginal notes complaining about the length of time since they received a letter from home. ${ }^{33}$

Historians can observe the communal nature of Prussian soldiers' letters, even messages dealing with matters that might seem private. Hans Wölcke, a farmer's son from the village of Stavenow in Brandenburg, wrote home in 1757. He wrote home about a rather private issue: he was asking his former stepmother's hand in marriage. Wölcke and the object of his affections, Liese Hintzen, were around the same age, and had flirted as teenagers, before Hintzen's father had married her off to Wölcke's own father. After the death of Hintzen's much older husband,

\footnotetext{
${ }^{31}$ Zander, Fundstücke, 33.

${ }^{32}$ Ibid.

${ }^{33} \mathrm{Ibid}, 41,64$.
} 
she and Hans had continued their relationship, and indeed, had two children together. It was a strange and difficult situation, in fact, both Hans and Liese were later charged with incest. ${ }^{34}$ Despite this odd and potentially difficult situation, there was nothing private about Hans's letter home. Indeed, eight other soldiers wrote postscripts or marginal notes home to their loved ones in the same letter as Hans's marriage proposal. "Niklaus Hintze... greets his wife many thousand times." Mathias Hintze complained about his wife's lack of correspondence, saying, "he doesn't know what he should think that she hasn't once written to him. ${ }^{35}$ Even letters that contained sensitive communication between husband and wife still carried messages from other soldiers to the village community.

Even more frequently than their post-scripts and marginal notations, the Zanders would include messages from family and friends with the army in the main bodies of their letters. More than just messages from soldiers with the army, these include pleas for letters from home for other men: "Every day, we wake up hoping to get a letter from you, but it does not come. All of our comrades alike ask for letters from home. Please write more about how business is going, and whether or not the work is finished." ${ }^{36}$ Soldiers' letters became a vehicle for connecting not only the primary author to his family, but for emotionally connecting the entire village, even though its members were physically dispersed. Perhaps even more importantly, communal letter writing kept men from the same village in close contact with one another in the army. In addition to aiding the transit of letters via a free military postal system, Frederick II celebrated soldiers'

\footnotetext{
${ }^{34}$ William W. Hagen, Ordinary Prussians, 508.

${ }^{35}$ GStAPK, HA X, Rep. 37, Stavenow, Nr. 496.

${ }^{36}$ Zander, Fundstücke, 38.
} 
loyalty to family and community as a motivation for soldiers in difficult times, and wrote about it, as chapter five will discuss. ${ }^{37}$

This was the emotional core of the sentiments produced by appeals to kin and home made by Frederick the Great in the course of the Seven Years War. In Frederick's famous "Parchwitz Address," given on the eve of the Battle of Leuthen in 1757, he appealed directly to family connections: "Bear in mind, gentlemen that we shall be fighting for our glory, the preservation of our homes, and for our wives and children. Those who think as I do can rest assured, that if they are killed, I will look after their families." ${ }^{38}$ The geopolitics of the Seven Years War made it possible for Frederick to characterize this war as a defensive conflict for the preservation of Prussia, and this narrative resonated with common soldiers, even if, in all likelihood, the king referred only to the families of his officers.

Rudolph Kaltenborn, an old officer writing in the 1790s, recalled that the speech was often repeated by Prussian soldiers "who could never hear it without tears, and although they were under arms, these rough and unfeeling soldiers would cry like children." ${ }^{39}$ Frederick, in appealing to family and home, understood that he touched his soldiers at a deep emotional level. Frederick II of Prussia realized that soldiers fought as a result of cohesive bonds of loyalty and devotion. Much has been made of Frederick's famous statement that soldiers should fear their officers more than the enemy. ${ }^{40}$ Indeed, Sascha Möbuis has written an excellent monograph showing the tactical reasons this statement could not be true, exploring both the tactical

\footnotetext{
${ }^{37}$ Christopher Duffy, The Military Experience in the Age of Reason, (New York: Atheneum, 1988) 128.

${ }^{38}$ O. Herrmann, "Prinz Ferdinand Von Preussen über Den Feldzug Vom Jahre 1757," Forschugen XXXI (1918): 101-2.

${ }^{39}$ Rudolph Wilhelm von Kaltenborn, Briefe Eines Alten Preussischen Officiers Verschiedene Characterzüge Friedrichs Des Einzigen Betreffend (Hohenzollern, 1790), 53.

${ }^{40}$ Friedrich II, Instruktion für die Commandeurs die Infanterie-Regimenter, 11 May, 1763.
} 
underpinning of the Prussian Army, as well as the religious, patriotic, and material motivations of Prussian soldiers. ${ }^{41}$ Frederick, in less well-known statements, emphasized the communal bonds of the village, region, and canton-district as the most important element in fostering courage among soldiers. Of his cantonists, he recalled in 1768, "These... citizen-soldiers [soldatscitoyens] are all from the same locale. Many of them are relatives and know one another ... these cantons give encouragement and bravery, for friends and relatives who fight together, do not give up easily." ${ }^{42}$ In the case of native cantonists, local connections to friends and family provided more cohesion in combat than the threats of officers, as demonstrated by the heavy casualties sustained by units in combat, such as Regiment von Itzenplitz at Hochkirch, and Frederick II's half of the army at Torgau.

Military observers and authors, such as the comte de Mirabeau and the officer Jakob Mauvillion observed the Prussian army after the Seven Years War. These writers asserted that local connections were at the heart of Prussian military success. In his view, soldiers' "connections to their homes were not just beneficial, they guaranteed the victories of Frederick II." He also found that "the men of each regiment are drawn from the same province, and all are well acquainted. This makes their lives easier, and creates a sort of comradeship most useful on the day of battle." Like Frederick, Mirabeau thought that local connections were the glue that held the Prussian army together under fire. The French nobleman even gave some prescriptive advice: why not name the regiments after their canton districts, rather than their commander? "The embodied spirit could be perfected still further, if the regiments were named after their

\footnotetext{
${ }^{41}$ Sascha Möbius, Mehr Angst Vor Dem Offizier Als Vor Dem Feind?: Eine Mentalitätsgeschichtliche Studie Zur Preußischen Taktik Im Siebenjährigen Krieg (Saarbrücken: VDM Verlag,., 2007), 16-28.

${ }^{42}$ Friedrich II und Gustav Berthold. Volz, Die Politischen Testamente Friedrich's Des Großen (Berlin: Hobbing, 1920), 139.
} 
districts, rather than their commanders." ${ }^{43}$ As revealed by their letters, the writings and speeches of their king, and foreign observers, the Prussian Army contained a high degree of loyalty to place and family. This localism translated well into regimental loyalty, as chapter six will demonstrate. The Prussian regiments, however, were not the only eighteenth-century force which embodied this localism, and the chapter will now turn to evidence of local loyalty in another army.

\section{JACOBITE SOLDIERS' LETTERS}

Letters from Jacobite soldiers to their families indicate local attachments resembling those found in Prussian soldiers' correspondence. This portion of the chapter examines the letters of Scottish Jacobite soldiers during the 1745 Jacobite Rebellion. During the uprising, a part of the larger war of Austrian Succession, Prince Charles Edward Stuart led an attempt to overthrow the ruling Hanoverian dynasty of Great Britain and restore the Stuart family to the throne. After landing in Scotland with a few supporters, the Prince was supported extensively by the French, raised a significant army and won victories in Scotland. Following these successes, the Jacobite force invaded as far south as Derby in England before eventually being driven back and defeated at the Battle of Culloden. There is a great debate about the exact nature of the "Highland Army" which the Stuart Prince led, and Stuart Reid argues that essentially it consisted of four types of soldiers: first, highland troops who initially served as a result of social obligation to their lords; second, men who were selected for service as militiamen; third, troops who were forcibly conscripted by threat of force; and finally, men who willingly volunteered for service. ${ }^{44}$ Like much of the scholarship which challenges the traditional romantic view of the Scottish soldiers

\footnotetext{
${ }^{43}$ H. G. Mirabeau and J. Mauvillion, Systeme Militaire De La Prusse Et Principes De La Tactique Actuelle Des Troupes Les plus Perfectionnees. Extrait De La Monarchie Prussienne (London, 1788), 78.

${ }^{44}$ Stuart Reid, 1745: A Military History of the Last Jacobite Uprising,(Staplehurst: Spellmount, 1996), 199-201.
} 
of this rebellion, Reid, together with Christopher Duffy and Murray Pittock, point to the idea that many Jacobite soldiers were conventionally equipped like most European soldiers and organized into relatively advanced operational units, but that they also maintained a connection to their traditional way of fighting. ${ }^{45}$ Far from being a wholly traditional force, the Jacobites (like the Prussian Army) seem to have relied on localism and kinship ties even as they partially adapted to new ways of fighting. Even as Jacobites were armed with new French muskets, and drilled in more modern combat methods, their army remained organized by clan regiments, which drew on kinship ties. A set of correspondence captured by the Hanoverian government in late 1745 has survived, offering a snapshot of Jacobite soldiers' letters. Although most of the sixty letters come from officers, perhaps twenty come from unidentified or low-ranked men. The recipients of these letters are indicated in Figure $3 .^{46}$

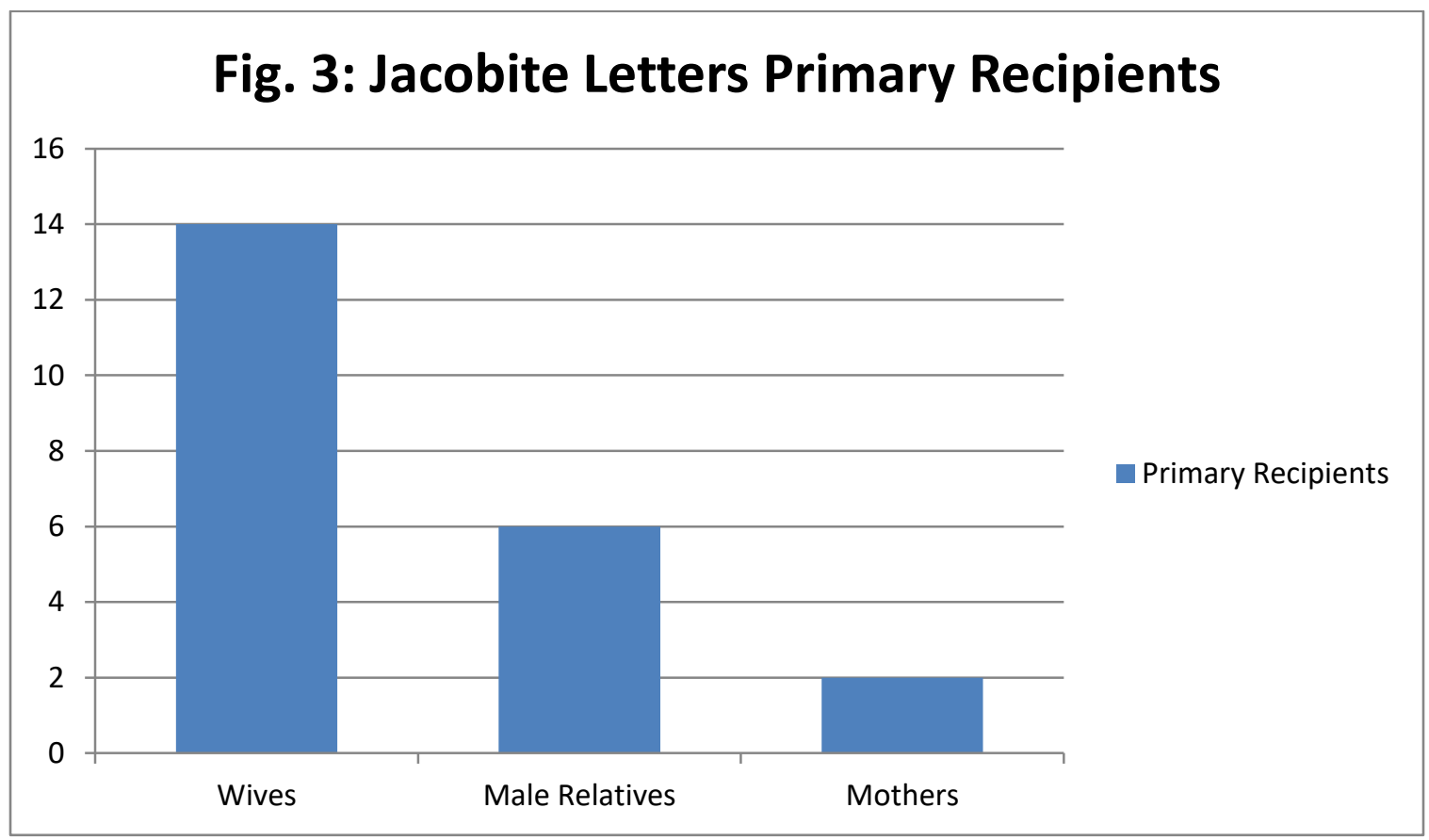

\footnotetext{
${ }^{45}$ Reid, 1745, 204-205, Christopher Duffy, Fight for a Throne (London: Helion, 2014), 312-339, Murray Pittock, The Myth of the Jacobite Clans,(Edinburgh: Edinburgh University Press, 2009), 163-182.

${ }^{46}$ All letters are drawn from: National Archives of the United Kingdom (TNA) SP 54/26/122
} 
Like Prussian soldiers, Jacobites primarily wrote home to their wives. The only explicitly identified common soldier among the letter-authors, Sgt. Duncan Macgillis of Macdonell of Glengarry's Regiment, wrote to his fiancée Margaret on October 30, 1745. Margaret had previously sent Duncan a letter, and he acknowledged the receipt of it, saying he was "glad to hear that [she] was in good health." Furthermore, Duncan pointed to the network of local connections supporting the Jacobite Army: Margaret had previously sent a letter by way of the son of a man known to both of them, Allan Roy, but this letter, for some reason, had not reached the army. He indicated that he missed Margaret: "we are in opinion every day to march on to England and being a sergeant and having the trouble of the company, and God knows how soon I can present my love to you, and nevertheless my love is as constant to you as it was formerly." A close reading of the letter indicates that Duncan and Margaret were not yet married, as he both indicates that they will "make all things complete" upon his return to Scotland, and furthermore writes that she should "give my service to your children," indicating that these could be children from a previous marriage. Duncan's single letter gives a sense that literate common soldiers in the Jacobite army were capable of maintaining a correspondence with their loved ones via local connections during the war of $1745-1746 .^{47}$

Another letter, from Donald Macdonell, likely a common soldier in the Duke of Perth's Regiment, refers to previous letters carried by a local boy, to whom Donald refers as "young Leek." Like Duncan Macgillis, Donald writes his mother to inform her of the possibility of an invasion of England, and that he might be away for some time. He transmitted some of his pay home for his mother with the letter, and also asked the same "young Leek" to give some ribbon for his sister as a present. Macdonell's letter does not show any awareness of the overall Jacobite

\footnotetext{
${ }^{47}$ TNA SP 54/26/122/363
} 
operational plan, and he mentions with surprise that other regiments were joining the portion of the army he was stationed with, notably the Mcpherson Regiment and "Athole People." In the absence of a formalized military post system, using acquaintances to carry letters drew on the Jacobite's local ties, and attempted to keep the army and its constituents connected. ${ }^{48}$

Of this collection of letters from Jacobite soldiers, one letter stands out. On a single sheet of paper, there are two distinct messages, written in slightly different hands, likely from two brothers, or close male relatives, Evander and Alexande McIver. Evander wrote to his mother, Rorie McIver, seemingly regarding a dispute with their local gentry. He noted, "I have written to the lard about what you requested me in your letter and have delivered to his honer to send me word how he has a mind to do with you." Evander continued, noting that this noble was obligated to him as a result of his military service, and that his mother should "send me an answer of this with the first opportunity and send me world how my wife is and all friends at home[.]" On the same sheet of paper, Alexande McIver wrote to his wife directly, assuring her of his "kind love" and asking that she write to him via his brothers. Once again, local and family connections facilitated the carrying of letters across the British Isles. In a marginal note, Alexande begged his wife to "give my kind services to my mother in law and my brothers." There is also a slight indication that Alexande felt somewhat shy about writing intimate details to his wife in a letter which was a joint writing from Evander: "I would be kinder but not having the opportunity, I hope you will excuse me." This particular letter demonstrates the local and family nature of military letter writing between Jacobite common soldiers and their families during the last great Jacobite rising. Although occasionally noting military details, these men were primarily

\footnotetext{
${ }^{48}$ TNA SP 54/26/122/367
} 
concerned with maintaining a connection to their wives and loved ones, using their family and local connections in order to transmit their letters. ${ }^{49}$

Both Prussian and Jacobite soldiers wrote to similar correspondent groups. Though both their armies and families were structured in slightly different ways, Prussian and Jacobite soldiers both drew on local connections in their letter writing. The surviving letters from Prussian and Jacobite soldiers draw on similar motifs: assurances of love, a desire to be reunited with the family unit, and requests to be remembered to extended family and friends. There were differences, though: for example, Hans Wolcke's inclusion of details regarding an ongoing incest trial in a letter with messages for other soldiers contrasts strongly with Alexande McIver's shyness regarding affection to his wife in a communal letter. This could be a result of personality or cultural differences. On the whole, however, Prussian and Jacobite letter writing cultures share many similarities. Some of these similarities are shared by all soldiers attempting to communicate with their loved ones, but the local nature of military recruitment in both portions of the Prussian and Jacobite militaries also help to explain some of these common threads. Having examined two comparable cultures of letter writing among eighteenth-century soldiers, the remainder of the chapter now examines a third which shows significant differences: the British Army which served across the globe between 1739 and 1789.

\section{BRITISH SOLDIERS' LETTERS}

Before the 1782 Army Reforms British soldiers were sometimes, though not always, disconnected from the locality from which they were drawn. Young British men often used military service in order to escape what they viewed as domestic problems, such as fatherly

\footnotetext{
${ }^{49}$ TNA SP 54/26/122/375
} 
responsibilities or an unfavorable apprenticeship. ${ }^{50}$ British letter writers demonstrate that this hasty departure could cause a rift with their local communities, though not all letters reflect soldiers who have abandoned their responsibilities or created tension in their communities. Those who did leave under dubious circumstances, however, often used their letters as a way of asking for forgiveness for abandoning their domestic responsibilities in joining the army. With this said, there are definitely examples of soldiers whose correspondence shows a continued devotion to their kinship networks and local communities, much in the same way that Prussian and Jacobite soldiers did. Approximately sixty letters are included in the dataset which makes up Figure $4{ }^{51}$

\footnotetext{
${ }^{50}$ For examples of this type of soldier, see the memoirs and letters of Sampson Staniforth, Duncan Wright, Samuel Hickson.

${ }^{51}$ These letters are drawn from: TNA FO 95/5/3; HCA 30/272/3 ; HO 42/46/32; SP 36/72/124; SP 36/84/2/8; WO 28/8/137; NAM, 1976-07-40; 1986-11-1; 2008-06-4; British Library, Letters and other Papers of Samuel Hickson; Bedfordshire and Luton Archives and Record Service, R 769; Gloucestershire Archives, D4582 Bowly Family of Cirencester; Gloucestershire Archives, D153 Jackson Family of Sneyd Park; The Berkshire Record Office, R/D/134/13; Lancashire Archives, DDX 2743/MS5237; QSP/1996/9; Dorset History Centre, D/WIB/C/93; D/HAB/F17; Lambeth Palace Library, Beloe Papers, MS 3263, f. 148; National Records of Scotland, GD248/509/3/74; William L Clements Library, Schoff Revolutionary War Collection; Society of the Cincinnati Library, MSS L1992.1.477; John Wesley, The Journal of the Rev. John Wesley, A.M., ed. Thomas Jackson, Volumes 1-2, (London: Wesleyan Conference Office, 1869), Anonymous, British Glory Reviv'd, (London, J. Roberts, 1743); E. Linn, "The Battle of Culloden" , JSAHR, (1921-2).
} 


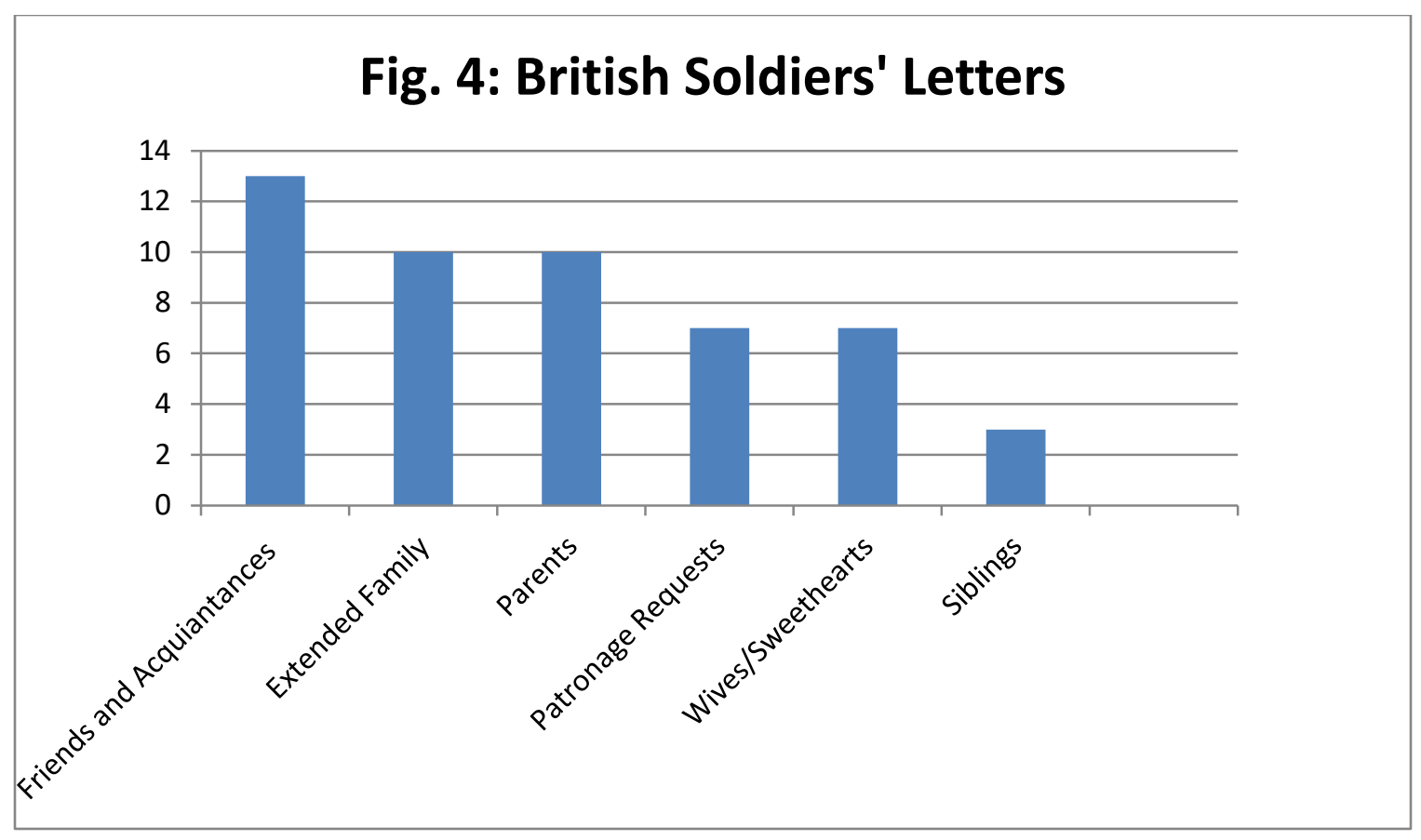

Unlike the letters of surviving Jacobites and Prussians, British soldiers did not write most frequently to their wives; indeed, letters to wives and sweethearts make up a very small portion of the total surviving correspondence of British soldiers. Rather, the nature of their enlistment frequently meant that they were unmarried and unattached at the time of recruitment. As a result, although they frequently wrote to their family, both their parents and extended family, they also wrote home to friends and acquaintances. This lack of correspondence between soldiers and their wives does not necessarily mean that soldiers in the British service esteemed their families or local communities any less than Prussians or Jacobites, but with a lack of a clear correspondent (a wife) who literally represented them in their village community, they were forced to seek out intermediaries who could represent them to a family who might have been angered by their departure.

For soldiers who fled from their family responsibilities, writing a letter was a vital first step for the eventual reintroduction to the village community. A first letter home, not directed to 
the immediate family but to a trusted third party or friend, could do much to heal the initial emotional wound of flight or anger which had separated the soldier from his village community in the first place. Samuel Hickson, who fled from his family to serve in the British forces in the subcontinent of India, wrote two letters to friends and acquaintances before writing to his mother. First, he wrote to a prominent man of business in his home area, Mr. Egeer, in order to ask for money and patronage. He followed that letter, almost immediately in summer 1779, with a letter to his former schoolmaster, Mr. John Smith, begging him to be an intermediary between Hickson and his family. Concluding the letter, Hickson asked for a final time, "let my mother, relations and friends... know that I am alive." Hickson only followed up to a member of his immediate family later, writing his mother in December of 1781: "I would have you free from all apprehension as to my situation." ${ }^{, 52}$ Hickson realized that his flight from the family farm had placed his mother in a difficult situation, and continued his letter:

I shall eagerly embrace the first opportunity to return to you.... I sincerely hope that God will raise up friends to protect you from distress and that my return, if it should please God to grant me that indulgence, I may find you and my brothers and sisters happily, give my kind love to them all and believe me to be your truly affectionate though unhappy son. ${ }^{53}$

In this passage, Hickson implores God to pick his own economic slack, and also seems serious in his desire to return home. By leaving the family for India, Hickson placed his mother in a position where she would need economic assistance. Conscious of this embarrassment, Hickson used an intermediary to broker relations with his family, and then employed religious language in order to demonstrate his sincerity in desiring to help his mother economically and be reunited with his family.

\footnotetext{
${ }^{52}$ British Library, European Manuscripts, \#B296, Letters and other Papers of Samuel Hickson 53 Ibid.
} 
Not content simply to ask God for assistance in assisting his family, Samuel Hickson wrote to one of his male relatives, his cousin Mr. J. Hickson, in order to express his gratitude for the cousin's help in caring for the mother and siblings the soldier had left behind. Samuel Hickson had received a letter from his brother William, informing him,

that you [J. Hickson] live in the house in which I left my mother, and that you are very kind to her. This has given me a great deal of satisfaction as I have suffered great uneasiness from the fear that she might be in distress in her old age, without a friend, whilst I was at such a distance that it was absolutely impossible I should assist her. $^{54}$

Samuel, in writing to his cousin, expresses both gratitude and remorse, simultaneous downplaying the nature of his absence. Hickson continued to his cousin, "I hope and trust you will continue your kindness to her for my sake, as well as the whole family, and should providence ever put it in my power to make you a return for it, it will be a great pleasure to me." Here, Hickson continues his gratitude and follows it up with a vague indication of financial reward, once again couched in religious language: “All I can do at present is to return you my sincere thanks, and give you an account of the transactions in my life since I left you. By the perusal of which if your curiosity is in any way gratified, it is the only demonstration of my gratitude you can at present receive." Here, Hickson offers the story of his military service as cultural currency in lieu of actual financial reward for his cousin's care for his immediate family. Hickson demonstrates the strength of kinship ties and local communities, indeed his flight into the army forces these networks to care for dependent members of their communities. Hickson's letters provide a window into the sheepishness which soldiers felt after abandoning their social

\footnotetext{
${ }^{54}$ Ibid.
} 
responsibility to their families, and the religious and cultural steps they took to excuse their behavior and find embrace in their village communities once again. ${ }^{55}$

Other British soldiers entered the army with the blessing of their village communities and maintained a close correspondence with them throughout their military careers. A cavalry soldier named Hooper wrote his wife just after the Battle of Dettingen in 1743. Most of the letter is a fairly mundane description of the battle. On the same sheet of paper as this letter, however, John Griffith, a drummer in the same regiment as Hooper, wrote a short inscription to his mother and sister, evidence of strong family and local connections in the British Army in the same manner as the Prussian Army. ${ }^{56}$ Another example of this type of familial mail is a letter from Thomas Plumb, a soldier in Captain McDonald's company of the $22^{\text {nd }}$ Regiment of Foot, who wrote home to his family while serving in North America on February 22, 1777. Plumb addressed his letter primarily to an Alexander Johns, to whom he referred as his brother, and was likely his brother-in-law. The letter indicates that Plumb's wife was in close contact with Johns; the secondary recipients included "wife, child, and all enquiring friends[.]" Plumb wrote frankly regarding the challenges of combat during the war, and indicated potential problems facing the British force: "our present state and situation in this country at the present time our duty is very hard[.]" Plumb, like the Prussian and Jacobite soldiers encountered above, greeted a host of relations near the close of his letter: "my kind respects to my loving wife and child, Uncle Wood, Molly, and Little William, and all enquiring friends." The letter provides a clear indication that for some British soldiers, family, kinship, and local communities remained a constant source of interest and encouragement as they were deployed on other continents. As he was finishing the letter, a final thought struck Plumb. Out of space in the body of the page, he moved to the

\footnotetext{
${ }_{55}^{55}$ British Library, European Manuscripts, \#B296, Letters and other Papers of Samuel Hickson

${ }^{56}$ Anonymous, British Glory Reviv'd, (London, J. Roberts, 1743), 42-43.
} 
margins, and wrote a final understated but firm instruction: "Your [ans]wer by the first opportunity." $" 57$

Like Plumb, William Calder, the soldier introduced at the beginning of this chapter, was worried that it had been a long time since he had received a letter from his extended family: "Let me know... how many letters you got from me since I left you, this is the forth and I should like to know whether you get them or not." ${ }^{58}$ Like the Jacobite soldiers earlier in the chapter, Calder used friends to carry letters to his family. His letter of February 10, 1781 was carried to his family in Glasgow by a Sergeant on recruiting service there, Sgt. Boyle. Calder informed that Boyle "would be glad to drink a bottle of ale or Dram with you on my account or with any of my relations." ${ }^{59}$ Sergeant Boyle also carried Calder's letter of June 3, 1782, which informed the family of the discharge of their kinsman from the military. Corporal Brock carried Calder's letter of May 25, 1784. These letters clearly point to the absence of a reliable military post system, but also indicate that soldiers who were determined to correspond with their families found ways around these obstacles. British soldiers, then, wrote letters that simultaneously match and deviate from the patterns found in the Prussian and Jacobite letters. Some British soldiers, like their Prussian and Jacobite counterparts, wrote to their families and village communities, clearly displaying emotional bonds to both. Others, having fled from their social responsibilities into the army, attempted to use letters as a way of mediation in their village worlds following their departure.

\footnotetext{
${ }^{57}$ Thomas Plumb to Brother, February 22nd, 1777, Box 82J, CA 30/272/3, High Court Admiralty Papers, TNA ${ }^{58}$ NAM, 1986-11-1-1

${ }^{59}$ Ibid, 5 .
} 


\section{CONNECTIONS TO THE CIVILIAN WORLD: LABOR}

Married soldiers, then, retained a firm connection to their civilian communities. Soldiers also retained a connection to the civilian world when they actively labored in civilian trades. Ulrich Bräker also described the civilian-military relationship in eighteenth-century Prussia. Bräker's observations of 1750s Berlin leave little room for doubt: soldiers retained civilian trades in eighteenth-century Prussia: "I... saw hundreds of soldiers busily working at loading and unloading merchandise, or employed at timber-yards, there were clouds of soldiers at work everywhere. In the barracks also I found more of the same, soldiers pursuing a hundred different trades, from piecing to spinning. ${ }^{\text {"60 }}$ In terms of their daily life and work in peacetime, eighteenthcentury Prussian soldiers shared much with civilians. Bräker's view of soldiers and civilians working together speaks against the argument that soldiers and civilians developed mutually exclusive identities. Rather, as Beate Engelen has pointed out, since the era of Frederick William I, civilians and military effectively coexisted in the urban spaces of eighteenth-century Prussia. ${ }^{61}$

Christopher Duffy has shown how after the Seven Years War era, soldiers clearly mixed with civilian trades as Freiwächter, or off-duty workers. ${ }^{62}$ In the late Frederician age, Duffy indicated that there was so much "interpenetration" of military and civilian life that military officers sought to regulate the interaction between soldiers and civilians. In 1781, a daily order book instructed soldiers that "all the military men are given serious warning about the following: in the event of a master punishing a soldier, they must not interfere in the affair or create a mutiny. From now on the soldiers may not take wood from construction sites to their quarters in

\footnotetext{
${ }^{60}$ Bräker, Lebensgeschichte, 121 ..

${ }^{61}$ Beate Engelen, "'Fremde in Der Stadt: Die Garnisongesellschaft Prenzlaus Im 18. Jahrhundert,"' in Die Herkunft Der Brandenburger : Sozial- Und Mentalitätsgeschichtliche Beiträge Zur Bevölkerung Brandenburgs Vom Hohen Mittelalter Bis Zum 20. Jahrhundert, ed. Jürgen Theil, Olaf Gründel, and Klaus Neitmann (Potsdam, 2001), 116120.

${ }^{62}$ Christopher Duffy, The Army of Frederick the Great (Chicago, IL: Emperor's Press, 1996), 81.
} 
the evening. They may not linger too longer at their breakfast, for that results in the loss of work." 63 This entry shows that Ilya Berkovich may well be correct in some cases: soldiers were wary of their place within the civilian world, and disliked being ordered about by civilians. Yet evidence demonstrates that if soldiers needed to be reminded of their subordinate place in civilian life, and clearly remained disgruntled about treatment by civilian masters, they remained heavily integrated in civilian trades.

- Likewise, in rural Prussia, furloughed cantonists worked as farmers for much of the year. William Hagen has argued that these soldiers were occasionally a disruptive and violent force in village life, using examples such as of furloughed soldiers getting drunk and disorderly at weddings, becoming involved in petty crime, and exploding hand grenades as a practical joke. ${ }^{64}$ It is important to realize that using official village and court documents may skew the picture somewhat: court records are likely to produce a rather dim view of human nature. Villagers also often resented the special status soldiers were afforded as cottagers (Büdnerei). It is also clear, however, that soldiers retained civilian goals, using their military status as a means to advance themselves in civilian life by becoming cottagers, marrying well, and establishing themselves as heads of household. Hagen's sources, however, also reveal a world in which civilians displayed violence towards soldiers: cursing and threatening them with violence at legal hearings, beating them during disputes over game and threatening to clobber them with rocks. ${ }^{65}$ Tellingly, there were furloughed soldiers on both sides of some of these conflicts, so claims that soldiers acted as a group hostile to village interests appear misguided. ${ }^{66}$ It is doubtless correct that the presence of

\footnotetext{
${ }^{63}$ Gerhard August von Witzleben, Aus Alten Parolebüchern Der Berliner Garnison Zur Zeit Friedrichs Des Grossen (Berlin, 1851), 54.

${ }^{64}$ William H. Hagen, Ordinary Prussians, 466-472, 477.

${ }^{65} \mathrm{Ibid}$,

${ }^{66}$ Ibid, 469.
} 
young and armed men disrupted the village communities with occasional violence. With that said, it is also clear that violence marred the worlds of eighteenth-century villages without the presence of soldiers, who on the whole worked alongside their relations, and attempted to better themselves on their furloughs to the village community. ${ }^{67}$

Foreign observers on Prussian life also commented on the working lives of soldiers. Jacques Antoine, comte de Guibert, traveled to eighteenth-century Prussia shortly after the Seven Years War. There he observed that off duty soldiers roamed freely "without uniform of any kind, dirty, uncombed, ragged, going about just as they pleased. There are soldiers on every street corner, pursuing every means of employment imaginable." ${ }^{68}$ Berkovich has observed that the fact that Guibert could tell the men were soldiers was a sign that military life separated them from the civilian population, but the ragged, unkempt appearance of the soldiers undermines that interpretation. Guibert clearly depicts soldiers mixing freely with the civilian population, not harboring hostile attitudes towards them. Guibert concludes his remarks with an observation that would ring increasingly true in both military and civilian contexts across Europe in following centuries: "In Prussia they proceed from the principle that no kind of occupation can demean a soldier, as long as it brings in money." ${ }^{69}$ British observers noted with surprise that the Prussian army was quartered with the civilian population, living in ones and twos among the houses of Berlin, Königsberg, Küstrin, and Magdeburg. John Moore, a British traveler in Prussia, was shocked by the presence of soldiers' laundry hanging out the windows of civilian homes, and cited a few reasons for quartering troops on the civilian population: "that a connection and goodwill may be cultivated between the soldiers and their fellow- citizens; and that the former may

\footnotetext{
${ }^{67}$ For more on this point, see David Warren Sabean, Property, Production, and Family in Neckarhausen, (Cambridge: Cambrdige University Press, 1991).

${ }^{68}$ Jacques-Antoine-Hippolyte comte de Guibert, Journal D'un Voyage En Allemagne, Fait En 1773 (Paris, 1803), 166.

${ }^{69}$ Ibid.
} 
not consider themselves as a distinct body of men, with a separate interest from the rest of the community. ${ }^{70}$ In short, Prussian soldiers occupied a special place within Prussian society, but remained integrated into society, rather than wholly distinct from it. Furthermore, eighteenthcentury Prussian soldiers remained an active economic part of civilian society in ways which modern soldiers in the western world do not. "Interpenetration" between civilian and military society could at times cause friction when soldiers felt abused, but working alongside civilians remained a large part of Prussian soldierly experience.

This chapter has asserted that localism formed an important part of soldierly worldviews in Prussia and the British Isles during the eighteenth century. Soldiers, most of whom hailed from rural communities, maintained contact with those communities via the facility of letter writing. Family bonds and local connections helped construct Frederick II's army into the formidable fighting machine that survived, and therefore won, the Seven Years War. Soldiers stood by one another in the horrors of combat, not for some abstract idea of nationalism, or even a developing notion Prussian patriotism, but because they were sustained by their local communities. These local communities followed soldiers to the army, in the form of village comrades in the same unit, and communal letters from their villages. These emotional bonds, between soldiers within their regiments, and between soldiers and their village families at home, helped the Prussian army to sustain the horrible losses it suffered in the Seven Years War. Men in other armies, such as Jacobite and British soldiers, reflected similar but not identical connections to village life. The available sources make it clear, however, that the canton system and the military-civilian relationship in Prussia allowed for fuller development of these emotional bonds. For married men in Prussia and Britain, local identity and letter writing created

\footnotetext{
${ }^{70}$ John Moore, A View of Society and Manners in France, Switzerland, Germany, and Italy: With Anecdotes Relating to Some Eminent Characters (Philadelphia: Printed and Sold by R. Bell, 1783), 2:117.
} 
emotional ties. Even as eighteenth-century recruits began to form a distinct identity as soldiers, they retained a deep connection to the civilian world which they had left behind in their military service. Despite retaining fondness for their village communities, soldiers wrote letters from a world of violence, violence that was intentionally directed towards enemy troops, but occasionally caused friction with friendly civilians, as the next chapter will demonstrate. 


\section{"It is impossible to describe the misery of war": Violence and Soldiers in Britain, Prussia, and Beyond, 1618-1815}

Though soldiers faced a wide range of human experiences, what set them apart from the civilian life was their willing participation in a world of violence. Calling for a renewed study of the combat tactics of the eighteenth-century British army in 2008, Matthew Spring argued, "Yet if the ultimate purpose of all armies is to fight ... the most fundamental task facing the military historian is arguably to study combat." ${ }^{\text {T }}$ This study largely concurs with Spring's analysis, but argues that rather than simply combat, violence may be a better framework for understanding both the world of combat, and the relationship between soldiers and civilians. Violence, particularly the intensity of wartime violence, is difficult to concretely understand. When trying to quantify violence, there is always a danger that the experience, humanity, and reality of that violence will be lost. The history of violence, then, needs to be written as a careful tension between tragic experiences and statistics. Historians have explored violence against civilians during the eighteenth century in great detail over the last thirty years. ${ }^{2}$ At the outset, it is important to acknowledge that the experience of any violence is often traumatic, difficult, and painful. With that said, charting the intensity of violence may give historians a better window into the world of eighteenth-century battlefield experience, as well as experience of soldiers and

\footnotetext{
${ }^{1}$ Matthew H. Spring, With Zeal and with Bayonets Only: the British Army on Campaign in North America, 1775 1783 (Norman:University of Oklahoma Press, 2010), xi.

${ }^{2}$ M.S. Anderson, War and Society in Europe of the Old Regime, (London: Leicester University Press, 1988) John Childs, Armies and Warfare in Europe: 1648-1789, (Manchester: Manchester University Press, 1989), Mark Grimsley and Clifford Rogers, Civilians in the Path of War (Lincoln: University of Nebraska Press, 2002) Armstrong Starkey, War in the Age of Enlightenment, (Westport: Praeger, 2003), Sascha Möbius, "Kriegsgreuel in den Schlachten des Siebenjährigen Krieges in Europa," in Kriegsgreuel: Die Entgrenzung der Gewalt in Kriegischen Konflikten vom Mittelalter, (2008) Marian Füssel, "Féroces et barbares? Cossacks, Kalmyks, and Russian Irregular Warfare during the Seven Years War," in The Seven Years War: Global Views. eds Mark Danely and Patrick Speelman. (Boston: Brill, 2012) Erica Charters, Eve Rosenhaft, and Hannah Smith, ,Civilians and War in Europe, 1618-1815 (Liverpool: Liverpool University Press, 2014), Phillip Hamilton and Glenn Moots, Justifying Revolution: Law, Virtue, and Violence in the American War of Independence, (Norman: University of Oklahoma Press, 2018).
} 
civilians at war in eighteenth-century Britain and Prussia. This chapter will examine two types of violence: the combat violence exchanged between soldiers of hostile states, and the violence committed by soldiers against civilians.

The following pages explore soldierly violence within a broader chronological frame, including the seventeenth century and the Napoleonic wars in its analysis. Primacy is given to British and Prussian sources, but it also includes general information from across what Christopher Duffy and Stephen Conway have termed "military Europe..”3 First, the chapter will examine battlefield violence during the eighteenth century, arguing that eighteenth-century battlefield experience was not limited, formalized, or restrained. A generation ago, scholars articulated a very different view of eighteenth-century combat than the one which currently dominates the field. In the opening line of his important 1988 work, Military Experience in the Age of Reason, Christopher Duffy argues that "the time has long passed since it was fashionable to dismiss the eighteenth century as a decorative interval[.]"4 Duffy concluded that for soldiers during wartime,

The old musketeer knew the comfort of the campfire (and could never conceive that it would disappear from military life), and even when he was on campaign he was spared the sapping experience of physical danger for months on end; when, however, battle did arrive, it was likely to present itself in an overwhelmingly stressful form, and he had to face this ordeal...in the knowledge that the slightest wound might condemn him to the most terrible and lingering death. ${ }^{5}$

This study confirms Duffy's model for the intensity of combat during the age of reason. Far from being a formalized affair where soldiers and officers might engage in ritualized banter with enemy forces, this chapter argues that the eighteenth-century world of battle between soldiers

\footnotetext{
${ }^{3}$ Christopher Duffy, The Military Experience in the Age of Reason, (New York: Atheneum, 1988) 3-34. Stephen Conway. "The British Army, "Military Europe," and the American War of Independence." The William and Mary Quarterly 67, no. 1 (2010): 69-100.

${ }^{4}$ Duffy, Military Experience in the Age of Reason, 3.

${ }^{5}$ Ibid, 318.
} 
was no less a total war than that during the Wars of Religion or under the conditions of modern warfare.

Secondly, I argue that in terms of violence against civilians, the wars between 1648 and 1789 were less violent than the previous Wars of Religion, and the subsequent conflicts of the anti-Napoleonic Wars. This middle period, often referred to as the Kabinettskriege era by an older generation of German scholars, was supposedly a trough between two crests of violence, where professionalized soldiers were firmly subordinated to government control, civilians respected war as the sphere of the military, and nationalistic passions played little role in warfare. ${ }^{6}$ Over the last thirty years, a generation of scholars has disrupted this view by focusing on the violence, immediacy, and brutality of these wars. John Childs examined this topic in a European context thirty years ago, and since that time Franz Szabo, Erica Charters, Holger Hoock, and Marian Füssel, among others, have greatly added to our understanding of violence against civilians within specific conflicts in the eighteenth century. I am not attempting to challenge the findings of these scholars, for whom I have a great deal of respect, but simply to provide another methodological window into this question. By examining the era as a whole, I argue, rather than attempting to isolate specific aspects of specific conflicts, a different picture emerges. The strength of the studies of these eminent historians is their focus on detail and specificity. By focusing on specific conflicts, however, or even on a particular theatre of a specific conflict, they often fail to address the wider picture of historical change over long periods of time. Instead, my work builds on their case studies to gain a broader perspective of eighteenth-century wartime violence. This chapter will begin to elucidate that larger picture. In order to make this argument, the paper will first explore statistical approaches to measuring

\footnotetext{
${ }^{6}$ Siegfried Fiedler, Kriegswesen und Kriegführung im Zeitalter der Kabinettskriege, (Koblenz: Bernard \& Graef, 1986).
} 
violence, before moving on to personal accounts by combatants and non-combatants. The chapter then concludes with an analysis of a violence in fictive sources, in order to understand the influence of the Enlightenment and the revolution in sensibility on the violence of war.

The older, standard interpretation, which viewed the "Kabinettskriege" era as a period of limited warfare compared to the previous wars of religion and future Napoleonic conflict was first challenged by British historian John Childs. In 1989, writing with the express intention of challenging the thesis of limited warfare during the 1648-1789 era, Childs began his book with a quote which has become standard reading for military historians on this era:

the word limitation must be employed with great circumspection; between 1648 and 1789 wars in Europe accounted for the lives of hundreds of thousands of soldiers and civilians, destroyed numerous towns and villages, damaged national economies, and devastated much of Germany, central Europe, and the Low Countries. Warfare was 'limited' only when it was compared with the holocaust that had gone before and the new totality of the Napoleonic Wars. ${ }^{7}$

Childs's book repeatedly features a woodcut image depicting the destruction of a village by seventeenth-century soldiers. This image, "Plundering and Burning a Village," from Jacques Callot's Les Grandes Misères de la guerre, is designed to drive home to the reader how violent war could be. Childs fails to address, however, the point that the image was published in 1631, and depicted troops plundering during the horrors of the Thirty Years War. These minor quibbles aside, since its publication three decades ago, Childs' interpretation has become the dominant school of thought on the military history of this era. Writing in 2008 on the Seven Years War, Franz Szabo largely echoes Childs' conclusion: “The Seven Years War on the European continent was costly, bitter, and sanguinary far beyond what might be imagined from the frequently expressed stereotypical image of the 'civilized' and 'limited' warfare of that

\footnotetext{
${ }^{7}$ John Childs, Armies and Warfare in Europe: 1648-1789, (Manchester: Manchester University Press, 1989), 2.
} 
century." ${ }^{8}$ Szabo echoes the sentiments of the most important work addressing this topic: Erica

Charters, Eve Rosenhaft, and Hannah Smith's excellent edited volume Civilians and War in

Europe, 1618-1815. The editors come to the balanced conclusion that,

the conduct of war after 1648 undoubtedly became more regulated but the label of 'limited' or 'restrained' fails to convey the complex range of military experiences and civilian-military relations that can be found in the period between the end of the Thirty Years War and the start of the French Revolutionary and Napoleonic Wars. ${ }^{9}$

My conclusions parallel those of the authors cited above, but address the same questions in a quantitative way. Recent works by Sascha Möbius, Marian Füssel, Cole Jones, and Holger Hoock have followed a similar trend, emphasizing the violent nature of both battlefield and military-civilian interactions during the Seven Years War and American War of Independence. ${ }^{10}$

\section{LIMITATION AND VIOLENCE ON THE BATTLEFIELD}

In terms of battlefield violence, the eighteenth century was not any more or less limited than any other period in human history. Eighteenth-century soldiers fought and died as soldiers on the battlefield and experienced its full range of horrors. In order to understand their actions and performances on the battlefield, we must first turn to what combat was like during the War of Austrian Succession. The wars of the eighteenth century have often been dismissed by

\footnotetext{
${ }^{8}$ Franz A. J. Szabo, ,The Seven Years War in Europe: 1756-1763(Harlow: Pearson Longman, 2008$), 434$.

${ }^{9}$ Erica Charters, Eve Rosenhaft, and Hannah Smith, ,Civilians and War in Europe, 1618-1815 (Liverpool University Press, 2014), 8.

${ }^{10}$ Sascha Möbius, "Kriegsgreuel in den Schlachten des Siebenjährigen Krieges in Europa”, in: Sönke Neitzel/ Daniel Hohrath (Hg.), Kriegsgreuel. Die Entgrenzung von Gewalt in kriegerischen Konflikten vom Mittelalter bis ins 20. Jahrhundert, Paderborn u.a. 2008, S. 185-203.; Holger Hoock, Scars of Independence: America's Violent Birth (New York: Crown, 2017). Cole Jones, Captives of Liberty: Prisoners of War and the Politics of Vengance in the American Revolution (University of Pennsylvania Press, 2019). Marian Füssel, Der Preis des Ruhms: Eine Weltgeschichte des Siebenjährigen Krieges, 1756-1763, (Munich: C.H. Beck, 2019), 373.
} 
historians of other eras as "wars in lace" or a "decorative interval."11 This view, often spawned by a reading of Voltaire's description of the Battle of Fontenoy in the War of Austrian Succession, has officers doffing feathered cocked hats amicably talking with the foe about how battles should be sequenced. Manuel de Landa has argued that soldiers were mere "clockwork" instruments on the battlefields in the eighteenth century, that they had no loyalty, or drive, as the soldiers of Napoleon possessed. ${ }^{12}$ Ilya Berkovich strongly challenged this argument with regards to motivation with his recent book, Motivation in War. Still, many military historians continue to view combat in the eighteenth century as robotic, limited, and formalized. ${ }^{13}$ This view needs to be complicated by the wealth of evidence that suggests that eighteenth-century soldiers reacted to the stress of battle in much the same way as modern soldiers. In the eighteenth century, soldiers took cover, compensated for the stress of battle by firing as quickly as they could without orders, ran and moved at speed across the battlefield in order to avoid being shot, fled from combat, and experienced trauma or what we today think of as PTSD. The structure of wars of the Kabinettskriege era may have been more limited than the conflicts that preceded or followed them, but soldiers continued to experience battle in incredibly visceral and terrifying ways.

In the traditional view of eighteenth-century warfare, infantry soldiers exchanged fire by volleys of ranks and platoons that they practiced on the drill square. ${ }^{14}$ In reality, soldiers often responded to the danger of combat by lying down, both with and without orders. At the Battle of

\footnotetext{
${ }^{11}$ Alexander Martin, "The Last "War in Lace" or the First "Total War"?" Kritika: Explorations in Russian and Eurasian History, vol. 15 no. 2, 2014, pp. 293-301. Christopher Duffy, Military Experience in the Age of Reason, 3. ${ }^{12}$ Manuel de Landa, War in the Age of Intelligent Machines (New York, NY: The MIT Press, 1991), 60-65.

${ }^{13}$ For an example of this type of thinking among a prominent scholar in the field, see: John Lynn, The Bayonets of the Republic Motivation and Tactics in the Army of Revolutionary France, 1791-94 (Boulder, CO: Westview Press, 1996).

${ }^{14}$ J. A. Houlding, Fit for Service: The Training of the British Army, 1715-1795(Oxford: Oxford University Press, 1981), 351.
} 
Fontenoy in 1745, Sampson Staniforth described lying down under orders to avoid being shot by enemy artillery:

We marched up boldly; but when we came close to the town of Fontenoy, we observed a large battery ready to be opened on us. And the cannon were loaded with small bullets, nails, and pieces of old iron. We had orders to lie down on the ground; but for all that, many were wounded, and some killed. Presently after the discharge we rose up, and -marched to the first trench, still keeping up our fire. ${ }^{15}$

Staniforth described a similar encounter at the Battle of Lauffeld in $1745 .{ }^{16}$ At the same battle, the Royal Highland Regiment (the future $42^{\text {nd }}$ Regiment or Black Watch) fought in a similar manner. The Regiment's officer, Colonel Sir Robert Munro, ordered his men, "to clap to the Ground on receiving the French Fire ; and instantly, as soon as it was discharged, they sprung up, and coming close to the Enemy, poured in their Shot upon them[.]"17 This system of alternatively taking cover and returning fire is similar to the tactics which modern armies use in the twenty-first century. Further evidence of this type of fighting comes from the letters of Lt. Colonel Russell of the British Guards. Russell observed the Battle of Dettingen in 1743, and described the infantry combat in a letter to his wife:

That the Austrians behaved well also is true; that except one of their battalions which fired only once by platoons, they all fired as irregular as we did; that the English infantry behaved like heroes, and as they were the major part in the action to them the honor of the day is due; that they were under no command by way of Hide Park firing, but that the whole three ranks made a running fire of their own accord, and at the same time with great judgment and skill, stooping all as low as they could, making almost every ball take place, is true, that the enemy, when expecting our fire, dropped down, which our men perceiving, waited till they got up before they would fire as a confirmation of their coolness as well as bravery, is

\footnotetext{
${ }^{15}$ John Telford, Wesley's Veterans: Lives of Early Methodist Preachers, (Salem, OH: Schmul Publishers, 1912), $1: 79$.

${ }^{16}$ Ibid, 89-90.

${ }^{17}$ Philip Doddridge, Some Remarkable Passages in the Life of the Honourable Col. James Gardiner: Who Was Slain at the Battle of Preston-Pans, September 21, 1745 ; (Printed for J. Buckland, W. Strahan, J. and F. Rivington, Hawes, Clarke and Collins, W. Johnston, S. Crowder, 1772), 253.
} 
very certain; that the French fired in the same manner, I mean like running fires, without waiting for words of command, and that Lord Stair did often say he had seen many a battle and never saw the infantry engage in any other manner is as true. $^{18}$

In addition to describing the process of taking cover, this passage also describes the tendency of soldiers to fire without orders. In another battle connected to the War of Austrian Succession, Prestonpans during the Jacobite 1745 rebellion, Lord Dunmore observed, "the Fire of our Foot was infamous, Puff, Puff, no Platoon that I heard." ${ }^{19}$ Dunmore's use of the sound of firing, "Puff, Puff," is illustrative that soldiers were firing without orders, using their own judgment.

Other armies struggled with this phenomenon. The future Prussian army reformer and Major General, Johann Gottfried Hoyer, commented on the issue of soldiers firing without orders near the end of the eighteenth century. Describing the differences between peacetime training and actual combat, Hoyer observed:

In fact, all these types of firing were practiced in peacetime on the drill-square, but soldiers hardly used them in serious combat. Once there, everything was abandoned for running fire [Plackerfeuer], that is, everyone loaded and shot for himself as fast as he could. This is highly embarrassing, as, after one hundred years of practice, we cannot bring common soldiers under control, and build an unfeeling shooting-machine. In the heat and confusion of battle, the instrument is only set in motion by the artist's finger. Some exceptions [to the general rule of running fire], which may be found among the Prussian troops, and only with them alone, have been made possible through their ceaseless practice. They can prove nothing against the universality of the idea shared here. ${ }^{20}$

\footnotetext{
${ }^{18}$ Frankland-Russell-Astley Rosalind Alicia et al., Report on the Manuscripts of Mrs. Franklin-Russell-Astley: of Chequers Court, Bucks (London: Historical Manuscripts Commission, 1900), 278.

${ }^{19}$ John Cope, Peregrine Lascelles, and Thomas Fowke, ,The Report of the Proceedings and Opinion of the Board of General Officers, on Their Examination into the Conduct, Behaviour, and Proceedings of, Sir John Cope, Peregrine Lascelles, and Thomas Fowke, from the Time of the Breaking out of the Rebellion in North-Britain in the Year 1745, till the Action at Preston-Pans Inclusive (London: Printed for W. Webb, 1749), Appendix page 38.

${ }^{20}$ Johann Gottfried von Hoyer, Geschichte Der Kriegskunst (Rosenbusch, 1797), 102-103.
} 
Hoyer's comment that "after one hundred years of practice, we cannot bring common soldiers under control, and build an unfeeling shooting machine" is very telling. Officers might have desired to build an army of unthinking submissive automata, but they were unable to accomplish that goal. Understanding this failure to construct "an unfeeling shooting-machine" is necessary in order to grasp the true complexity and chaos of eighteenth-century battlefields. Hoyer's disappointment at being unable to control his soldiers was echoed by many British officers in the War of Austrian Succession era. ${ }^{21}$

Both officers and common soldiers noticed the need to leave drill manuals behind and move speedily on the battlefield. French soldiers in the War of Polish Succession noted that when trying to reach embattled comrades, they "moved almost as in a race: the most nimble arrived first, their arrival awakened courage and new strength to those already engaged in combat. ${ }^{22}$ Comments like this echo throughout records left by eighteenth-century armies, even those not dedicated to speed in attack such as the Swedish Army in the Great Northern War and British Army in the American War of Independence. ${ }^{23}$ A Prussian officer from the Fusilier Regiment of Jung-Braunschweig at the Battle of Prague in 1757 noted:

In order to reach the position of advance, we had to pass a long dam, which delayed us. So, in order to arrive at the correct time, we had to run past the village of Arhem: the regiment was not in perfect order. The [Austrian] enemy were already advancing on us at the quick step, and we engaged them. ${ }^{24}$

\footnotetext{
${ }^{21}$ John Houlding, Fit for Service, 350-358.

22 Jacques de Mercoyrol, ,Campagnes De Jacques De Mercoyrol De Beaulieu, Capitaine Au régiment De Picardie (1743-1763), ed. Vogüé Melchior and Auguste Le Sourd (Paris: Renouard, H. Laurens, successeur, 1915), 184.

${ }^{23}$ See, Peter Englund, The Battle That Shook Europe: Poltava and the Birth of the Russian Empire (London: I.B. Tauris, 2013) and Matthew H. Spring, With Zeal and with Bayonets Only: the British Army on Campaign in North America, 1775-1783(Norman: University of Oklahoma Press, 2008).

${ }^{24}$ Anonymous, Sammlung ungedruckter Nachrichten, (Dresden: Waltherischen Buchhandlung, 1782) 4:118.
} 
This source is significant, as it describes both the Prussians and their Austrian enemies moving at speed, something historians typically fail to associate with battles in the mid-eighteenth century. At the same battle, Prussian Musketeer Johann Jakob Dominicus noted, "our left wing had its work cut out for it, and we had to run with energy, in order to get under the enemy cannon."25 Austrian Major Dominicus Sanctes Tomioti de Fabris led his grenadiers to the attack down an icy slope at Maxen by sliding down the ice "on his backside." ${ }^{26}$ Far from being an accident, the rest of his unit followed his example in order to come to grips with the Prussians more quickly. Just as they took cover to avoid harm, when the situation required it eighteenth-century soldiers would leave their drill manuals with cadence steps behind and "run with energy" on the battlefield to avoid enemy fire.

The actions previously described are all rational actions taken by soldiers on the battlefield in order to increase their chances of survival. The horror of combat was real for eighteenth-century soldiers and many of them felt great fear. Particularly at the start of a battle, while being bombarded by artillery, soldiers recorded feeling great fear. ${ }^{27}$ Prussian Feldprediger Karl Daniel Küster noted that soldiers experienced the shock of battle in different ways. He recalled,

I have often spoken with both high and low ranking officers, as well as the brave enlisted men, regarding this so-called, "cannon-fever." They are all in one accord that only boastful liars have never felt horror in battle at the prospect of death. They also commented, and I have also noted, that this sense (of cannon-fever) spreads during the early, middle, and last stages of a battle. During the early stages, the strong men support the weak, and a general flight only occurs when

\footnotetext{
${ }^{25}$ Johann Jacob Dominicus, ,Aus Dem Siebenjährigen Krieg: Tagebuch Des Preußischen Musketiers Dominicus ; Nebst Ungedruckten Kriegs- Und Soldatenliedern, ed. Dietrich Kerler (München: Beck, 1891), 16.

${ }^{26}$ Christopher Duffy, By Force of Arms: The Austrian Army in the Seven Years War, (Chicago: Emperor's Press, 2008) 2:203.

${ }^{27}$ Ulrich Bräker, ,Lebensgeschichte Und Natürliche Abentheuer Eines Armen Mannes Von Tockenburg (Zurich: Hans Heinrich Füssli, 1789), 147;, see Christopher Duffy, Military Experience in the Age of Reason, 218-219.
} 
this disabling fear affects the morale of the majority of the army, and both the strong and weak flee together. ${ }^{28}$

Küster's descriptions demonstrate the fear that all soldiers faced in battle during the eighteenth century. As a Prussian Feldprediger, Küster accompanied his men into battle, and experienced the terror of combat himself. The Prussian army was attacked at the Battle of Hochkirch in 1758, and Küster saw combat first-hand. He recalled that experience left him shaken:

the so-called cannon-fever or battle-shiver came over me in all of its power. But God graciously granted that this happened later, on the other side of the village of Kitlitz when the danger was almost over. I stood alone, near the regiment, and quickly, a dizzying fear overtook me, fright with trembling limbs, such that I could have been knocked over by a weak child. ${ }^{29}$

Christopher Duffy describes a similar instance of battle terror at the Battle of Kunersdorf in 1759, when the Russian Corps of Observation was bombarded with artillery to the extent that surviving soldiers simply sat on the ground and would not defend themselves when attacked. ${ }^{30}$ Thus, while modern terms such as Post Traumatic Stress Disorder may not be completely helpful, soldiers from the eighteenth century experienced "shell-shock" or "combat fatigue" quite similar to that of the modern era.

\section{LIMITATION AND VIOLENCE TOWARDS CIVILIANS}

In contrast to the combat soldiers faced on the battlefield, civilians benefited from changes in army organization and professionalization. Ultimately, these eighteenth-century structural reforms reduced the violence civilians had faced during the preceding century of religious warfare. With the end of the Thirty Years War, European states, from Sweden to

\footnotetext{
${ }^{28}$ Karl Daniel Küster, ,Des Preussischen Staatsfeldpredigers Küster, Bruchstück Seines Campagnelebens Im siebenjährigen Kriege ... Nebst Einem Vorbericht Des königl. Herrn Oberkonsistorialraths Sack. Zweyte ... Stark Vermehrte Ausgabe (Berlin: Karl Massdorfs, 1791), 62.

${ }^{29}$ Ibid, 60.

${ }^{30}$ Duffy, Military Experience in the Age of Reason, 254.
} 
Austria and Spain to Brandenburg, began to professionalize their previously mercenary armies.

During the wars of religion, regimental commanders were something like independent contractors, selling their services to various monarchs. In the late seventeenth and early eighteenth centuries, soldiers increasingly became tied to the state; their service was still contracted, but they swore oaths of loyalty to particular royal houses. Highly trained soldiers became a valuable asset for an individual ruler, and, increasingly, armies were supported by vast systems of fortified depots which allowed them to receive regular supplies of food, clothing, equipment, and pay. All of these structural changes, taken on with the goal of solidifying the power of the ruler and the state over their armed forces, had the unintended consequence of bringing soldiers more tightly under the control of their officers, establishing degrees of discipline and subordination impossible with the mercenary model of the wars of religion. This structural change had wide-ranging implications for the development of military-civil relations between the end of the Thirty Years War and the beginning of the Napoleonic era. ${ }^{31}$

Historians need not subscribe to the idea that eighteenth-century warfare was a model of limitation and respect for civilians to recognize that, compared to the mass violence of the Thirty Years War and Napoleonic Era, the Kabinettskriege era wars became less violent, and fewer human lives were lost in military conflict. To provide scale for the number of civilian deaths, Chart One draws on a number of estimates of total war-related deaths between 1618 and $1815 .{ }^{32}$ In the process of creating Chart one, I was challenged with the imprecision of record keeping

\footnotetext{
${ }^{31}$ Michael Howard, War in European History, (New York: Oxford University Press, 2009), 20-37, 54-74. Derek McKay, The Great Elector, (Longman: New York, 2001), 169-178.

${ }^{32}$ Alexander Mikaberidze, The Napoleonic Wars: a Global History(Oxford: Oxford University Press, 2020). Micheal Clodfelter, Warfare and Armed Conflicts: a Statistical Encyclopedia of Casualty and Other Figures, 1492 2015(Jefferson, NC: McFarland \& Company, Inc., Publishers, 2017). Peter H. Wilson, The Thirty Years War: Europe's Tragedy(Cambridge, MA: Belknap Press of Harvard University Press, 2011).William Eckhardt, "Civilian Deaths in Wartime," Bulletin of Peace Proposals 20, no. 1 (1989): pp. 89-98. Jack S. Levy, War in the Modern Great Power System: 1945-1975(Lexington, KY: University Press of Kentucky, 1983).
} 
prior to the twentieth century, as well as various methods of calculating casualties and losses.

Nevertheless, the decline of civilian deaths is striking.

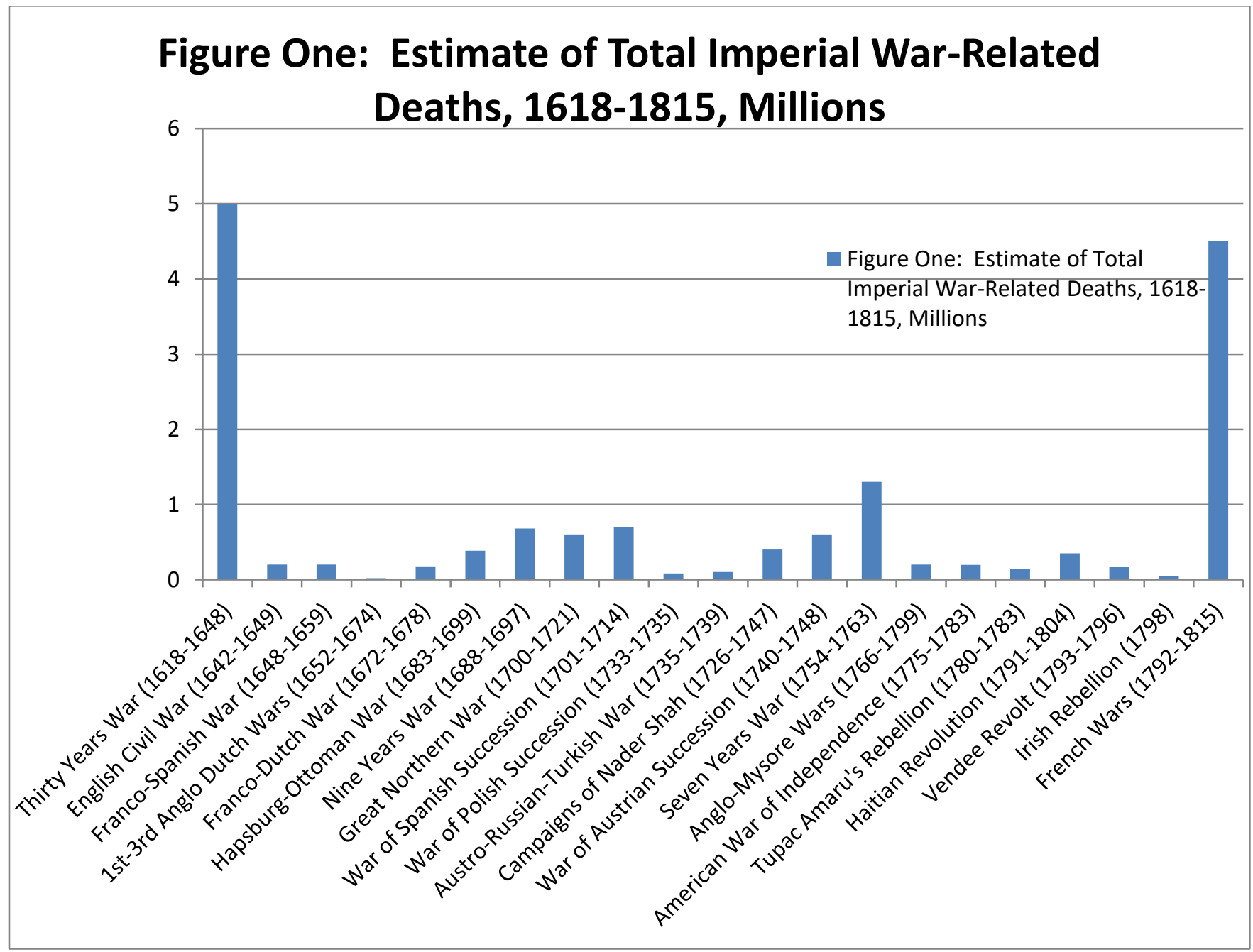

Figure One, then, is a compilation of estimates of all war-related deaths from the Thirty Years War, the French Wars of 1792-1815, and the largest conflicts between those dates. In creating the chart, I have configured the data in a way that is most prejudicial to my hypothesis, by coupling conservative estimates from the Thirty Years War and Napoleonic Wars with the highest estimates available for the wars in between these two conflicts. The data still show that far more people lost their lives in the fifty-odd years of the Thirty Years War and French Wars 
than died from war-related causes in the 140 years between those conflicts. More precisely, by a conservative estimate nine million people lost their lives during the Thirty Years War and French Wars, whereas just fewer than six million people died during the eighteen largest wars in between those conflicts. When we turn to civilian deaths, the data becomes both more striking and difficult to quantify.

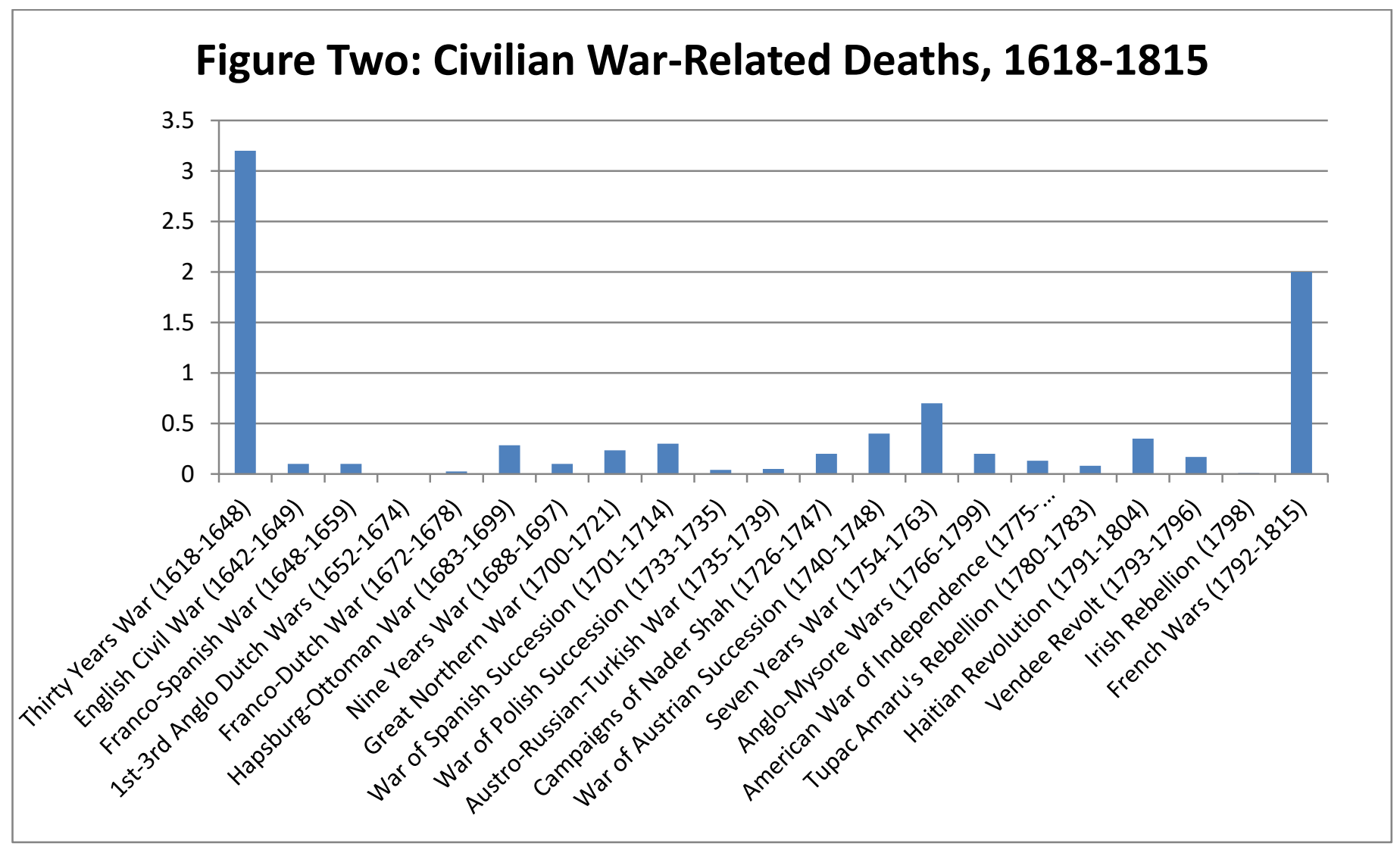

Figure Two provides an estimate of the civilian deaths related to armed conflict between 1618 and $1815 .{ }^{33}$ Once again, the estimates for the Thirty Years War and the French Wars are

\footnotetext{
${ }^{33}$ Alexander Mikaberidze, The Napoleonic Wars: a Global History(Oxford: Oxford University Press, 2020).Micheal Clodfelter, Warfare and Armed Conflicts: a Statistical Encyclopedia of Casualty and Other Figures, 1492-2015(Jefferson, NC: McFarland \& Company, Inc., Publishers, 2017). Peter H. Wilson, The Thirty Years War: Europe's Tragedy(Cambridge, MA: Belknap Press of Harvard University Press, 2011).William Eckhardt, "Civilian Deaths in Wartime,” Bulletin of Peace Proposals 20, no. 1 (1989): pp. 89-98. Jack S. Levy, War in the Modern Great Power System: 1945-1975(Lexington, KY: University Press of Kentucky, 1983).
} 
conservative to average, whereas high figures have been selected for the wars between those dates. The Seven Years War stands out for its relatively large number of civilian deaths; the American War of Independence total is high as a result of the smallpox epidemic running concurrently with that conflict. Once again, if roughly five million civilians died as a result of the Thirty Years War and French Wars, perhaps two and a half million died during the course of the wars of the Kabinettskriege era. Although the numbers are closer than total war-related deaths, there is still a distinct trough between the crests of the Thirty Years War and French Wars.

These statistics provide an understanding of violence across Europe, but what about the relationship between soldiers and civilians in Britain and Prussia during and after the period studied by this dissertation? Despite increases in the professionalization of eighteenth-century armies and new logistical programs, soldiers and civilians continued to live in close proximity to one another. Soldiers and civilians coexisted as soldiers marched through, were quartered in, requisitioned supplies from, and worked alongside civilian communities. Thus, historians can obtain a measure of how badly civilians despised soldiers, or, to frame it another way, how often soldiers proved a nuisance to civilians, via the records of civilians asking for soldiers to leave their communities. Fortunately, a number of these sources survive in archival holdings. In Britain, there are records of these requests between 1758 and 1809, whereas in Prussia, records exist squarely across the entire period from 1739 to 1815 . These types of requests were issued by various bodies, usually innkeepers, and sometimes entire villages and towns requested to be free from the duty of having soldiers quartered on them. 


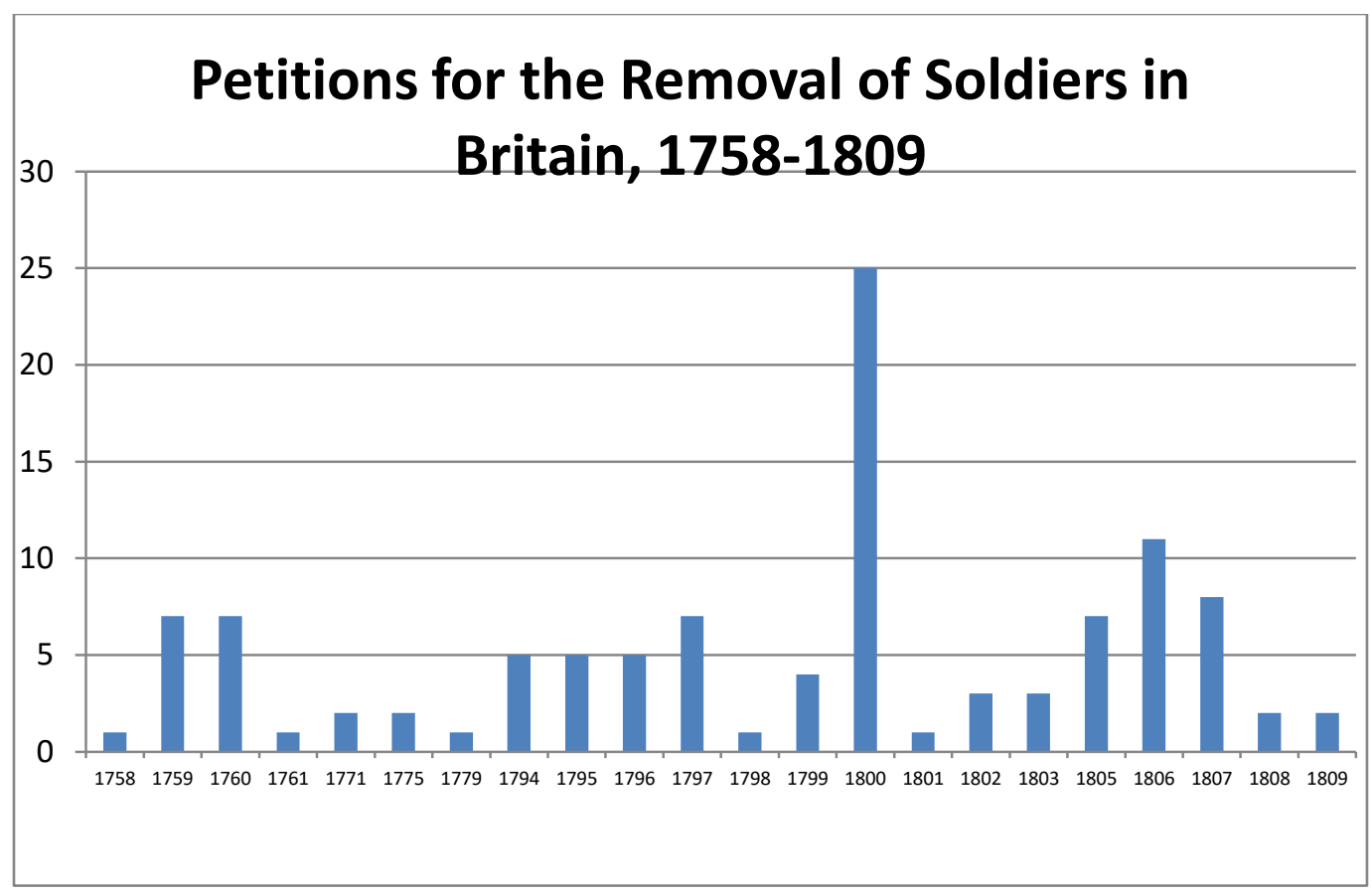

Figure Three displays requests for soldiers to be moved out of communities in Britain, submitted to the Secretary for War between 1758 and $1809 .{ }^{34}$ Out of the 142 requests preserved in this collection, 21 date from the $1758-1789$ period, 98 date from the 1790-1809 era, and 23 are undated. Even assuming that all the undated petitions come from the 1758-1789 period (a highly unlikely proposition), that still leaves 44 petitions from the earlier era, and 98 from the period of the French Wars. Even using that model, where the data is intentionally skewed against the idea of soldier-civilian coexistence in the Old Regime, double the amount of petitions were sent in Britain during the nineteen years of the French Wars, compared to the thirty-one years of the Old Regime.

With the exception of the Irish Rebellion of 1798, there was a lack of large-scale fighting in the British isles themselves during this period. Despite this, the British government kept a large number of soldiers active in garrison duty in England, Wales, Scotland, and Ireland. These

\footnotetext{
${ }^{34}$ These records come from: TNA, WO 40/3.
} 
soldiers often garrisoned strategically important coastal fortifications, which had towns in and around them. Recruiting parties crossed the length and breadth of the British Isles during this period, and seeing soldiers would not have been a rare experience for many Britons in this era.

On December 24, 1787, an anonymous innkeeper penned a representative example of this type of petition to the Secretary of War. The innkeeper desired to escape from the "daily insults" that he received from the $44^{\text {th }}$ Regiment of Foot, who behaved in a "very dangerous and riotous manner" when they came to his inn. ${ }^{35}$ The soldiers broke windows, disturbed the other customers, and generally made a nuisance of themselves. For this reason, the innkeeper asked for financial restitution, and that the $44^{\text {th }}$ Regiment be removed from the town. Although the petition is marked that it was received by the Secretary of War, it is not clear what, if any, action was taken by the Secretary in response to this petition. The number of petitions gathered in this way, specifically by the Secretary of War, indicates that petitions believed that their cases would be read and acted upon.

${ }^{35}$ TNAUK, WO 40/3. 


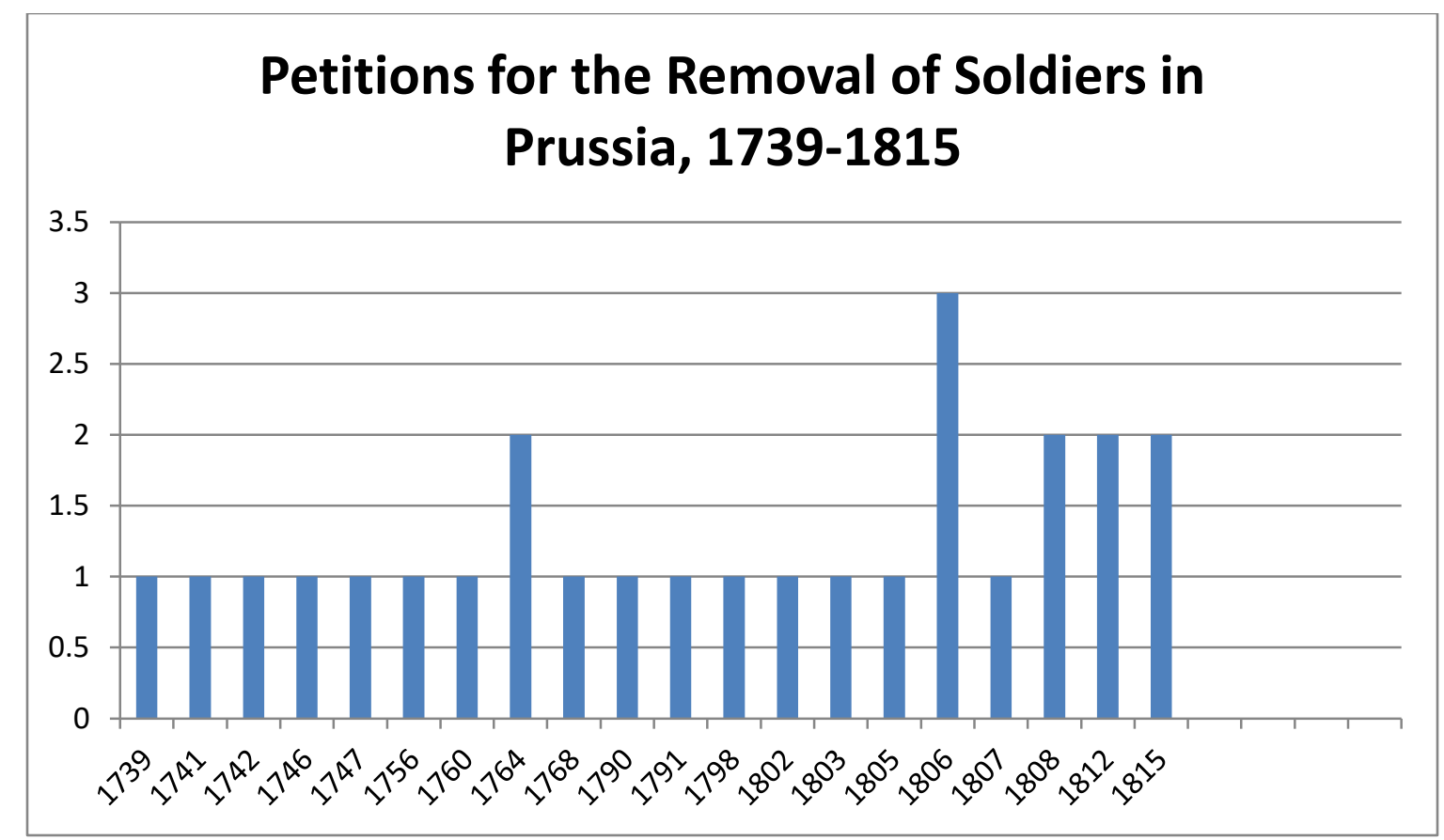

In Prussia, the numbers are less clear. Figure Four reproduces the petitions for removal of Prussian soldiers found in the Brandenburgisches Landeshauptarchiv for the years $1739-1815 .^{36}$ Of the twenty-nine dated petitions from the removal of soldiers from local communities during the 1739-1815 era, twelve come from the period between 1739-1789, and seventeen come from the period between 1790 and 1815 . The datum here are far too insignificant to make any sort of broad sweeping statements about the civilian-soldier relationship in Prussia during this time, but once again, more petitions were sent for the removal of soldiers in the twenty-five years of the Napoleonic era than during the fifty years of the Old Regime.

A representative example of the Prussian petitions is that of Berend Krüger, a Postillion in the village of Beelitz. After being accosted by the Potsdam garrison during one of his postal

\footnotetext{
${ }^{36}$ These petitions are drawn from collections across the BLHA; they are not collected as in the British sample. The collections containing these petitions are listed below by ascending collection number. See: BLHA, Rep 2A III, Nr. D9607; Rep 2 Kurmarkischer Kammer, D4041, F5342, S2152, S6432, S6482/1, S6483, S6964, S7206; Rep 3 Neumarkischer Kammer, 6688, 7288, 9203; Rep 3B III, Nr. D913; Rep 6B Soldin, Nr. 184; Rep 19 Lindow/M 60; Rep 19 Potsdam, 1162, 1277, 1568, 1571, 1576, 2472; Rep 17B, Nr. 3529; Rep 23 A, Nr. A 116, Nr. B 1794, Nr. C 1921; Rep 23B, Nr. 2936.
} 
rides in January 1747, Krüger sought damages against the garrison in the form of quartering payments (servis) as well as the removal of a Grenadier from his household in Beelitz. The case began in earnest in December 1755, and although the magistrate, Anton von Linger, noted that the officers of the garrison believed that Krüger's petition had merit, the case took over a decade to be fully resolved. A hearing was conducted in 1760, which involved not only the local magistrate but the General Directory, but the case was not fully resolved to Krüger's satisfaction until 1764. This episode demonstrates that the Prussian government responded effectively to civilian grievances against soldiers, but was slow moving, especially during times of war. ${ }^{37}$

Both the British and Prussian petitions for removal of soldiers show that there was a slight spike in petitions for the removal of soldiers during the Seven Years War, but that in both frequency and intensity of petitions, the Napoleonic era greatly overshadowed the Seven Years War. The data presented indicate that in addition to being categorically different in terms of the total number of deaths caused by warfare, as well as the number of petitions for the removal of soldiers, soldiers and civilians enjoyed calmer relations and tolerable coexistence during the Old Regime when compared with the French Wars in Britain and Prussia.

\section{QUALITATIVE EXPERIENCES: THE LONGER ERA}

The personal experiences of six individual soldiers and civilians offer perspectives on violence and suffering during this era of military history that cannot be captured by quantitative analysis alone. The following pages pair a source from an ordinary soldier and civilian from each of the three eras in question: two from the Thirty Years War, two from the eighteenthcentury wars, and two from the Napoleonic era. These sources do not present the full range of

\footnotetext{
${ }^{37}$ BLHA Rep 19 Potsdam, 1162
} 
the various types of violence which occurred in this era, but they provide a qualitative window which statistical numbers of deaths can never fully provide.

An anonymous diary, most likely from soldier Peter Hagendorf, provides historians with a dark view into the violence of the Thirty Years War. Born in the Northern Holy Roman Empire at Magdeburg, Hagendorf found himself fighting in the Imperial Army, and was present for the infamous sack of his home city. Hagendorf recalled being "deeply saddened that the city was burned so horribly both on account of the city's beauty, and because it is my fatherland."38 Though saddened, Hagendorf also noted that he was unable personally to take part in the sack because he had been badly wounded, and was dismayed on multiple occasions that he missed out on loot because of this fact.

Hagendorf's diary is relatively frank regarding harsh treatment of civilians. For example, "In Lippstadt there was good, old beer and also witches, I saw seven of them burned alive. Among them was a pretty girl of eighteen, but she too was burned."39 Hagendorf's writings lack emotion, and often pass over events of considerable horror with muted tones. In 1636, he recorded that "this bishopric [Liege] had three hundred churches and cloisters, eighteen cities, eighteen hundred towns, all of these, we, for the most part, plundered or robbed." Even when he describes the murder of civilians, his language is passive:

We... moved over to a castle. Within it were seven peasants who resisted the entire army. So we set fire to the castle and burned it up, along with the peasants... the peasants in the churchyard there resisted so forcefully that we could achieve nothing without cannons. Thus we went back, for there were one thousand peasants in there. Yet we set fire to their village and let it burn... 40

\footnotetext{
${ }^{38}$ Tryntje Helfferich, ,The Thirty Years War: a Documentary History(Indianapolis: Hackett, 2009), 283.

${ }^{39}$ Ibid, 282.

${ }^{40}$ Ibid.
} 
It is possible that Hagendorf is guilty of omitting violence in his diary. He describes passing through a particular region of the empire, near the city of Ulm, saying, "we went to Günzburg... [which] belonged to the city of Ulm. It is a village but they put three hundred plows to work in the field." This description, at face value, seems fairly peaceful. Hans Herble, a civilian living in this region, describes the movement of Hagendorf's army in more detail. At this point of the war, Hagendorf had switched sides to fight in the Swedish Army. The peasants in the region were not expecting to be attacked, because their city was already allied with the Swedish army that plundered the countryside. Herble relates that he and his fellow villagers were not expecting anything:

We considered him to be no enemy, and we were also not warned by the government... Then they fell upon us in the land and plunder all of us taking horses and livestock... and all of our poor belongings. They beat the people badly and shot, stabbed, and beat several of them to death... we fended them off for two days... but it did not help. And because we defended ourselves for a long time, they set fire to the town and burned five houses and five barns. ${ }^{41}$

Hagendorf's and Herble's diaries make it clear that soldiers in the era of the Thirty Years War paid little attention to the sufferings of civilians, and threatened, plundered, and murdered civilians at will, even civilians who were allied with their political leaders. Friendly alliances meant little to soldiers. The Thirty Years War, then, saw suffering on a tragic scale.

Soldiers' writings from the middle years of the eighteenth century paint a slightly different picture; even if it is one which still demonstrates that civilians suffered to a large degree. After the Seven Years War, Prussian Feldprediger Carl Daniel Küster recorded the memories of an old soldier, Gemeine Hoppe, who served in the Seven Years War. Hoppe

\footnotetext{
${ }^{41}$ Ibid, 315 .
} 
witnessed the suffering of Prussian civilians at the hands of Cossacks, not with indifference, but with empathy. Hoppe and his unit were deployed to protect the area around Küstrin before the Battle of Zorndorf in 1758 and saw the civilian population in the area suffering at the hands of the Cossacks. Likewise, the regular Russian army burned the city of Küstrin with a bombardment, which drew the ire of Prussian soldiers. Hoppe recalled, "We were smoldering with anger over the destruction of Küstrin and the sufferings of the poor country people. The enemy had wasted and destroyed everything, and even broken into churches and robbed them." Hoppe continued listing the depredations of the enemy, emphasizing the cruelty of the Cossacks. "The children were crying for bread, so we gave them most of our rations, for which they brought us water in return. Many of the people had been horribly injured or even killed by the Cossacks' whips. ${ }^{.42}$ Hoppe's recollections paint a story of Prussian empathy and sacrifice, even as Prussian armies committed similar atrocities in Saxony and on Austrian territory. Hoppe's narrative, however, makes it clear that by the middle decades of the eighteenth century, civilians and soldiers in the same state felt empathy for one another, and hatred for the suffering caused by common enemies, rather than hatred or indifference for each other.

During the American War of Independence civilians sometimes even met with restraint from feared enemies. During the War of Independence, Margaret Morris, a thirty-nine-year-old widow and mother of four in Burlington, New Jersey, dreaded the advance of the British army. Her community had sent several men to fight for the rebel army, and now a force of Hessian soldiers fighting for the British closed in on the town. Morris clearly held political opinions, and consistently referred to the rebel troops as "our army." Her writings express terror towards the Hessians, but when prominent men went out to meet the Hessian troops, the Hessian colonel

\footnotetext{
${ }^{42}$ Anonymous. Offizier-Lesebuch, Historisch-Militärischen Inhalts, Mit Untermischten Interessanten Anekdoten, Von Einer Gesellschafts Militärischer Freunde (Berlin: C. Matzdorff's Buchhandlung, 1793), 179.
} 
"found that upon being met in a peaceable manner, he was ready to promise them safety and security. ${ }^{, 43}$ There was a force of rebel galleys on the river, and negotiations proceeded between the Hessian colonel, the American amphibious force, and the civilians in the town. The Hessian colonel repeatedly pledged that, "if the inhabitants were quiet and peaceable, and would furnish him with quarters and refreshment, he would pledge his honor than no manner of disorder should happen to disturb or alarm the people." ${ }^{, 44}$ Finally, after the negotiations dragged on and on, the Colonel gave a final conditional offer:

He expected there would be no persons in the town in arms; nor any arms ammunition or effects, belonging to persons that were in arms against the king concealed by any of the inhabitants; that if any such effects were thus secreted, the house in which they were found would be given up to pillage. ${ }^{45}$

The Colonel ended his list of demands with the promise that, "if we acted openly and in good faith in these respects he repeated his assurances upon the honor of a soldier, that he would be answerable for every kind of disorder on the part of his troops.."${ }^{46}$ The American rebel boatmen, growing tired of negotiations, brought the process to a halt by firing swivel guns and cannons on the civilians in the town, whom they accused of giving shelter to the enemy. No one was seriously hurt in the bombardment. Margaret Morris's report demonstrates that even during the violence endemic to civil unrest and rebellion, enemy troops which the American civilian population viewed as notoriously brutal negotiated with regards to civilian safety, and that professional soldiers followed formal structures of civilian negotiation, giving at least some power to the idea that enemy civilians should be treated with restraint.

\footnotetext{
${ }^{43}$ Margaret Morris, Private Journal Kept During a Portion of the Revolutionary War, for the Amusement of a Sister,(Philadelphia: 1836), 7.

${ }^{44}$ Ibid.

${ }^{45}$ Ibid, 8 .

${ }^{46}$ Ibid, 9 .
} 
These sentiments strongly contrast with the experiences of soldiers in the Napoleonic Wars. The Napoleonic Wars saw a drastic change in the methods by which armies were recruited, sized, trained, and provided for. The mass armies of the Napoleonic era proved difficult to feed, and as a result, these structural changes modified relations between soldiers and civilians. Jacob Walter, a soldier in Napoleon's Army marching towards Russian in 1812, stopped at the town of Kalvaria in the Duchy of Warsaw. His unit had not been given food in some time, and he recalled,

No one had anything to eat. Since all is allowed by necessity, this little town, although already plundered, could not remain unsearched. All the soldiers ran for food and water, and it so happened that what provisions the inhabitants had hidden were found and brought into the camp, even though it was Polish country, and therefore, friendly. ${ }^{47}$

Officers eventually restored order in the town by threat of death, but Walter's phrase "all is allowed by necessity" goes some distance towards explaining his view of military-civilian relations in the Napoleonic era. Walter's interactions with civilians ran a gamut of diverse experiences, from impressing a pious family with vows of chastity, chasing peasant girls from dinner halls with crude humor, giving an infant enough brandy to become drunk, breaking into wine stores to obtain drink, beating a Jewish family for not giving him enough food, beating hostile civilians with clubs, to finally shooting Russian peasants who attempted to resist plundering. ${ }^{48}$ Walter's willingness to resort to violence against both friendly and enemy civilians stands in contrast to the relative empathy expressed by Gemeine Hoppe and the restraint of Hessians encountered by Margaret Morris.

\footnotetext{
${ }^{47}$ Jakob Walter and Marc Raeff, ,The Diary of a Napoleonic Foot Soldier(Moreton: Windrush, 1999), 39.

${ }^{48}$ Ibid, 5-57.
} 
Our Napoleonic civilian, Friedrich Ludwig Burk, a farmer living in Wiesbaden, had experiences similar to Walter, but was the tormented, rather than the tormentor. Burk begins his entry for 1813 with a chilling reminder: "One fears a sad year because of the horrible military events everywhere; whether the French are victorious or defeated, either way it will be bad for us." He continued, "the last French we had to billet left. We survived their retreat quite happily." The happiness was short lived. With Wiesbaden liberated from the French, Prussian forces began to requisition everything. Cossacks created disturbances in the streets. One diary entry simply reads, "Many people are dying now." Soldiers brought epidemic disease, hunger, and violence wherever they traveled. Burk's last entry for 1813 reads, "None of us will forget this year. Whoever has not experienced it personally would not believe the hardship war brings." When Russian soldiers moved into Wiesbaden, things seemed to go from bad to worse. He noted,

We got to know the Russians, who have tormented us for a whole month. [We] waited so impatiently for those we thought would be our deliverers but turned out to be our devastators. Even if the Russians come as friends and allies to Germany, we should still all take our guns and stop these barbarians. It is better to be dead... many people are dying.

Burk's entries are heart-rending and stand in clear contrast to the light-hearted manner in which Napoleonic soldier Jakob Walter related stories of the atrocities he had committed. ${ }^{49}$

There seem to be remnants of mid-eighteenth-century restraint in these Napoleonic experiences such as billeting of soldiers in houses and requisitioning of food for payment.

\footnotetext{
${ }^{49}$ All Burk quotes come from: Rafe Blaufarb and Claudia Liebeskind, Napoleonic Foot Soldiers and Civilians: a Brief History with Documents (Bedford: St. Martin's, 2011). For similar experiences, see: Ute Planert, Der Mythos vom Befreiungskrieg: Frankreichs Kriege und der deutsche Süden: Alltag-Wahrnehmung-Deutung, 17921841(Schoenigh Ferdinand, 2007). Philip Dwyer, "Violence and the revolutionary and Napoleonic wars: massacre, conquest and the imperial enterprise," Journal of Genocide Research Vol. 15, No. 2, (2013) 117-131; Phillip Dwyer, 'It Still Makes Me Shudder': Memories of Massacres and Atrocities during the Revolutionary and Napoleonic Wars', War in History, Vol. 16 Issue 4, (2009), 381-405.
} 
However, a marked feature of warfare in the Thirty Years War had returned: soldiers no longer cared whether or not the civilians they encountered were friendly or enemy: civilians were simply targets to be exploited. This factor alone stands out as a relevant distinguishing mark which separates many of the Kabinettskriege era conflicts from the wars which came before and after them. The great atrocities of the Kabinettskriege era, such as devastation of the Rheinpfalz and the destruction of civilian communities in Bavaria were all committed by soldiers on enemy populations. During the Thirty Years War and Napoleonic era, soldiers tormented both enemy and friendly civilian populations. That fact is significant. The hapless civilian from Wiesbaden Friedrich Ludwig Burk ends his story with a phrase which I would say describes all the conflicts I have mentioned, whether they are "limited", or unrestrained. Late in 1813, as more and more, supposedly friendly soldiers began to arrive in Wiesbaden, Burk noted, "It is impossible to describe the misery of war."

\section{QUALITATIVE EXPERIENCE: NARRATIVES OF SENTIMENTALITY AND WAR}

Having provided an example from this longer era, the chapter will now turn to fictive narratives, written in the eighteenth century, when the Enlightenment and notions of sensibility combined in fictional works describing soldiers. Throughout the eighteenth century, fictionalized narratives appeared, containing heartfelt emotive descriptions of the suffering brought on by constant warfare. In this section of the chapter, I evaluate a number of these sentimental stories of warfare, which link the horrifying experience of war with a tender reaction on the part of soldiers. From the late seventeenth century until the French Revolution, martial authors increasingly focused on combining military ideas with the philosophical trends of the Enlightenment. Historians have begun to study this phenomenon in detail, resulting in a number 
of case studies for particular nations and surveys of laws and literature. ${ }^{50}$ As the philosophers debated, Neuchâtelois jurist Emmerich de Vattel published his Le Droit des Gens in 1758. This work had wide-ranging influence across German Central Europe and the Atlantic World. This work is still cited by modern military codes as an authority on military law. ${ }^{51}$ Vattel, in discussing the rights of civilians and soldiers during wartime, noted that "instead of the custom of pillaging the open country and defenseless places, another mode has been substituted, which is at once more humane, and more advantages to the belligerent sovereign- I mean that of contributions. ${ }^{, 52}$ Vattel, in discussing the plundering of civilians, noted that there was indeed a change from the era of the Wars of Religion, and also indicated that, "a general who wishes to enjoy an unsullied reputation, must be moderate in his demand of contributions, and proportion them to the abilities of those who on whom they are imposed." 53 So, as the philosophers and jurists of the Enlightenment wrote regarding the laws of war, they noted qualitative differences between the present and the past, and called for moderation.

Across the Holy Roman Empire, this was the era of the Empfindsamer Stil, art which focused on the display of emotions. Eighteenth-century authors, far from expecting soldiers to be hardened by the experience of war, explored the possibility, in both fictional writing and reports of action from the front line, that soldiers could respond to the atrocities of war in heartfelt, tender, and sensitive ways. On December 15, 1785, a year after the conclusion of Fourth Anglo-

\footnotetext{
${ }^{50}$ Christy Pichichero, The Military Enlightenment: War and Culture in the French Empire from Louis XIV to Napoleon, Ira Gruber, Books and the British Army: in the Age of the American Revolution, Eugene Miakinkov, War and Enlightenment in Russia: Military Culture in the Age of Catherine II., See also, Armstrong Starkey, War in the Age of the Enlightenment, 1700-1789, (Westport: Praeger, 2003); Johannes Birgfeld, Krieg und Aufklärung: Studien zum Kriegsdiskurs in der deutschsprachigen Literatur des 18. Jahrhundert, (Hannover: Wehrhahn, 2012).

${ }^{51}$ Office of the General Council of the Department of Defense, Department of Defense Law of War Manual, (Washington: 2016) 35.

${ }^{52}$ Emmerich de Vattel, trans. Joseph Chitty, The Law of Nations, or Principles of the Law of Nature, (Philadelphia: Johnson, 1844) 365.

${ }^{53}$ Ibid.
} 
Dutch War, and eight months before the death of Frederick II "the Great" of Prussia, the London newspaper, General Evening Post, published a short story: "The fatal Effects of a too susceptible Heart, in a young PRUSSIAN OFFICER.” This story, which was drawn from the 1782 edition of James Douglas's Travelling Anecdotes through Various Parts of Europe, contains a fictive narrative, which is typical of this tender soldier genre. In this fictionalized story, when confronted by the horrors of warfare, a soldier rebels against the senseless destructive violence of war and reacts with genuine emotion about the horrifying nature of war.

In James Douglas's original narrative, the story is told as part of a dinner conversation between a British Colonel and a Prussian Major held in the Prussian exclave of Cleves. According to Douglas's account from the Prussian Major, he had been a captain during the Seven Years War, and his son had been an ensign in his same regiment. Of his son, the Major remembered: "We had served two campaigns together, and I was pleased with the marks of a cool and sensible courage which I had noted in him; and which on several occasions, promised the most flattering hopes, of his one becoming one day an ornament to his family." For all of his son's admirable qualities, however, the father noticed one deadly downfall: "his heart was naturally generous and tender- this virtue endeared me to him; but I trembled for its effects[.]" For the Prussian officer, this Major believed, a sensitive heart should have no place in warfare. The Prussian Major claimed that he took his son to witness executions, in order to make him aware of "the disastrous events which life is too often embittered with." 54 All of this, as we might guess, given the extreme melodrama with which the story is told, did not have the desired effect on the tender young Prussian officer.

\footnotetext{
${ }^{54}$ James Douglas, Travelling Anecdotes: through Various Parts of Europe (London: J. Debrett, 1782), 276.
} 
During the Seven Years War, the Major and his son were present when their portion of the Prussian army burnt an Austrian village to the ground. Upon regaining control of their marauding soldiers, the father-son pair explored the village. They encountered an old woman in a ruined house who begged the men to assist her in finding her children and grandchildren, who had taken refuge in a cellar to avoid the burning of the village. "If," the woman exhorted them, "you call yourselves men and not savages, of unequalled brutality, either kill me instantly on the spot and end my extreme sufferings, or O! let me have help to search for the remains of my children.” The son, being a tender sort, immediately ordered soldiers to help him search and clear away the burnt timbers of the house to reach the cellar. The Major continued his story, "We had not been long at work among the ruins, when we broke into the cellar whither the family had fled-here a scene presented itself, that would have turned a monarch's heart from the fell tide of war." Unsurprisingly, the party uncovered the asphyxiated bodies of the parents and children, and all the while, "the old woman with horrid yells was bewailing the loss of her unfortunate children-kissing the bodies, and frantic with grief[.]" In describing the horrible aftermath of a village burning from the Seven Years War, Douglas, whether his account is fictional or not, conveys the loss suffered by the peoples of Central Europe during a time of relatively limited war. ${ }^{55}$

This depressing scene has a predictable effect on the tender-hearted son of the Prussian Major:

My son stood with folded arms, musing over this melancholy spectacle- I solicited him to leave the place, I urged him to withdraw from so affecting a scene... in vain did I reason on the necessary consequences of war and conjured him to view this accident as a partial evil committed for the general good- that it was no premeditated cruelty, but one those casual misfortunes-which not only

\footnotetext{
${ }^{55}$ Ibid, 279-281.
} 
follows in the train of military transactions-but that even the civil transactions of life are oftentimes chequered with them. 'Where is your reason, your manhood, my boy? Shall a soldier view this sight, overcome with weak womanish feelings?-For shame! For Shame!-all men, in the course of their lives, must make up their minds to calamities like these-'tis what we are born to endure some time or other- away!- your countrymen will ridicule your want of firmness; and the laurels, which you have hirtherto acquired in the service, will only serve to point you out, as a more conspicuous instance of effeminacy. ${ }^{56}$

This passage is the heart of Douglas' narrative. Here, the Major, or Douglas, shows a willingness to accept civilian casualties as long as they are not caused by "premeditated cruelty." The writer reasons that these casualties were "necessary consequences of war," that they were an "accident... a partial evil committed for the general good," and that by refusing to display a stoic countenance in the face of this tragedy, his son lacks masculinity, and is acting in a feminine manner.

The Major's son does not take his father's criticism passively, but rather begins to respond, angrily: "Behold this unparalleled butchery of my countrymen!-will not the wrath of heaven revenge this outrage to humanity-cruel-cruel Prussians, you are bloody indeed!accursed profession!- hell only has invented thee!-from this instance I abjure thee." Here, the son, or Douglas, reproaches the conduct of war on the grounds of national shame, that it will invoke divine retribution, that it is an "outrage to humanity," and that the professionalization of war is an abomination. The writer continues, indicating that the extreme nature of this emotional reaction caused the son to take ill, and tragically, he passed away into a fever and never recovered. ${ }^{57}$ According to his father, the son had been overcome with the grief and misery of war: "his imagination was too strongly impressed with it; and such was the extreme delicacy and tenderness of his feelings, that I was destined to see this only child seized with a violent fever."

\footnotetext{
${ }^{56}$ Ibid, 281-282

${ }^{57}$ Ibid, 282-283
} 
Again, this story is written as melodrama, which is a strong point against a literal reading as an actual event. Regardless of the veracity of the story, the lesson is clear: the tenderhearted nature of the young Prussian officer turned him against his father, his state, and his profession, and literally killed him.

The narrative of the Major and his son is a salient example of this type of writing but is far from alone in expressing the response of tenderness and sentimentality. The tender soldier was not unique in British publications during the eighteenth century. In a late eighteenth-century British play by James Parkinson, The Soldier's Tale, an anonymous soldier converses with the protagonist, Hubert, on the horrors of war. This anonymous soldier states, "Good Heavens! What scenes of carnage have passed before these eyes! Never will my memory be freed from the cries and agonies of thousands I have seen fall, the victims of ambition and tyranny." The soldier continued,

'Painful reflection!' (and the tears which streamed down his cheeks shewed that his tongue was speaking the language of the heart), 'But,' said he, 'I hope when Mercy weighs my crimes, those actions which my busy, timid, self-accusing conscience is momentarily brining before my mind, will not be thrown in the scale against me. ${ }^{58}$

Here, the soldier reflects with remorse at the actions of his career, as well as the crimes that he himself has committed. Old soldiers also frequently wept in the short of German language literature of the day. Carl von Eckartshausen describes soldiers "crying like children" in various situations. ${ }^{59}$ In his 1777 comedy Das Schicksal des Soldaten (The Fate of Soldiers), one of Joseph von Aldersberg's characters states, "When a soldier cries, the scene must truly touch his

\footnotetext{
58 James Parkinson, The Soldier's Tale, Extracted from the Village Association (London: Eaton,1793) 4.

${ }^{59}$ Carl Eckarthausen, Erzählungen für empfindsame Herzen an Sonnabenden nach der Arbeit, (Munich: Strohl, 1784), 95.
} 
heart. ${ }^{, 60}$ The obvious tenderness in this fictive anecdote is matched by descriptions of eighteenth-century soldiers reacting to witnessing the devastation that war brought to friendly places. Christoph Seipp, in his travelogue on Silesia, noted, "Old soldiers are both tender and hard. The soldier weeps where the scholar is sensible." ${ }^{, 61}$ The British Annual Register for 1758 reported that on seeing a suburb destroyed by enemy fire, Austrian soldiers, "discovered so much humanity and tenderness on this occasion that they were seen, with tears in their eyes, readily parting with their own allowance of bread to the starving sufferers, they even gave them money." ${ }^{\prime 62}$ This narrative matches the description of Prussian soldiers by Hoppe earlier in the chapter. As a result of a revolution in sentimentality, soldiers had developed a grief reaction to witnessing the horrors of war, particularly when other soldiers carried out atrocities on friendly civilians.

\section{CONCLUSION}

During the eighteenth century, civilians continued to suffer at the hands of soldiers, as they had during the seventeenth century, and would again during the Napoleonic era. With that said, quantitative evidence suggests that fewer civilians died at the hands of soldiers during the eighteenth century. Far from being a result of a revolution in sentimentality or enlightened thinking, this change likely resulted from the increasing organization and professionalization of military forces during the later seventeenth and eighteenth centuries. The change having already occurred, enlightened jurists and sentimental authors captured it in their writing. Civilians would suffer and die again during the Napoleonic Wars, as states transitioned to mass armies with less

\footnotetext{
${ }^{60}$ Joseph Berhandtsky von Aldersberg, Der Graf von Sonnetnthal oder: Das Schichksal des Soldaten, (Munich: Churfürstlichen Genehmhaltung, 1777), 42.

${ }^{61}$ Christoph Seipp, Reisen von Preßburg durch Mähren, beyde Schlesien u. Ungarn nach Siebenbürgen,(Frankfurt und Leizpig: 1793) 396.

${ }^{62}$ Anonymous, The Annul Register for the Year 1758,(London: Dodsley, 1764) 175.
} 
training and control while struggling to provide adequately for those armies. Quantitative evidence also suggests that during the eighteenth century, soldiers and civilians from the same states occasionally interacted in disruptive ways, but that this pattern increased during the Napoleonic era. So, from the standpoint of humanity, as well as disruption of civilian life, the eighteenth-century wars appear to have been less damaging to civilians than the cataclysms of the wars of religion and French Wars. This picture of change over time is confirmed by the qualitative examples brought to bear on the question. The patterns of war in the seventeenth and early nineteenth century, from the perspective of both soldiers and civilians living at the time, indicate a high level of suffering on the part of the civilian population. Although that suffering is still present in the eighteenth century, it is reduced. This pattern is corroborated by legal works, and fictive tales like Douglas' story of suffering, where an older Prussian officer seemed to accept the cruelty of war, whereas his son was crippled by it. As the Prussian officer finished his tale of tragedy, Douglas recorded an interesting debate regarding the qualities of the British and Prussian army which occurred between the Prussian Major and an English Colonel. This exchange placed the two armies in close conversation with one another, debating the relative merits of their leadership styles, recruitment practices, and military ideas. As the two armies were connected by the work of elite officers, they also possessed similarities in other ways, such as intense feeling of religious devotion expressed by common soldiers. 


\section{"Fear God and Honor the King": British Methodist Soldiers, 1739-1789}

In early October 1739, John Nelson, a somewhat dissolute builder, was walking on the southern side of Hyde Park, when he heard an off-duty soldier begin to speak. This soldier, a private who had just been dismissed from guard duty, spoke to a group of other soldiers and Welsh women about the new birth of religious transformation which was occurring in his life. The soldier shared the story of his conversion experience. A new Christian movement had emerged as a result of the preaching of John Wesley. Whereas formerly this soldier had embraced a rough masculinity which he now described as sinful, he had been changed by the transformative power of the blood of Jesus Christ. Nelson listened to the soldier's speech, and he recalled that it "sank deeply into my mind, and made me cry more earnestly that God would work the same change in my heart." ${ }^{1}$ As a result, he converted to Methodism.

In Britain, the middle decades of the eighteenth century are not remembered as a particularly religious time. Rather, historians often frame this era as one of commerce and an expanding civil society, the paintings of Hogarth having replaced the religious hysteria of the previous century. Religion, it seems, fell more and more into the private sphere, as Britons became increasingly concerned with worldly affairs. More recent scholarship has tried to qualify this view, suggesting that religion was vital to the establishment of British identity. Together, these lines of inquiry have led to a vigorous debate about the nature of the eighteenth century: was it a time of religious renewal, or growing secularism $?^{2}$ This chapter examines religion as

\footnotetext{
${ }^{1}$ John Telford, Wesley's Veterans: Lives of Early Methodist Preachers, vol. 3 (Salem, OH: Schmul Publishers, 1912), 15.

${ }^{2}$ For the broad outlines of this debate, see: Roy Porter, English Society in the eighteenth century (London: Allen Lane, 1982). Patricia U. Bonomi, Under the Cope of Heaven (New York: Oxford University Press, 1986). Paul Langford, A Polite and Commercial People: England, 1727-1783(Oxford, 1989: Oxford University Press, 1989). Jon Butler, Awash in a Sea of Faith (Cambridge: Harvard University Press, 1990). Linda Colley, Britons: Forging the Nation, 1707-1837 (London: Pimlico, 2003).
} 
vital to the private lives of ordinary people by exploring Methodist soldiers in the British Army between 1739 and 1789. As a Christian confession, Methodism may bring to mind the conversion experience of John Wesley at Aldersgate, the earnest preaching of lay-ministers, and the hymns of Charles Wesley. Methodism is much less frequently remembered as part of the experience of soldiers in fighting in the British Army.

This chapter argues that Methodist soldiers were able to spread their faith across the army as a result of two important factors. First, Methodists benefited from, and at times even exploited, official indecision on the part of military authorities about their religious movement. This indecision amounted to informal toleration. Second, Methodists won converts by displaying a reckless fearlessness in the face of death, usually on the battlefield, but occasionally in judicial settings. The first assertion - that Methodists defied army leadership in order to embrace a civilian-led religious movement—challenges the idea that soldiers were developing an exclusive martial identity in the eighteenth century. The second argument — that Methodist soldiers used the chaos of the battlefield to advance their religious cause - challenges the idea that soldiers were simply automata on the battlefield during the eighteenth century.

Methodism became important to a subset of eighteenth-century British soldiers. Rather than grasping for the "average" soldier, this chapter explicitly focuses on men whose military lives were touched by the Methodist wave. Methodist soldiers attempted to maintain a distinct religious identity and often defied military authorities in order to do so. Rather than developing a martial identity hostile to civil society, by contrast, they followed the instructions of civilian religious leaders, and resisted the efforts of military authorities to conform their religious sentiments to those of the state church. Far from rejecting their state, however, these soldiers 
professed fierce loyalty to the ruling family of Great Britain even as they defied the king's officers in the army.

Methodist soldiers left behind a wide variety of sources. In addition to archival reports and manuscripts which survive from identifiable Methodist soldiers, this chapter draws on accounts of Methodist soldiers from the War of Austrian Succession era printed by Methodist magazines in the 1770s-1790s and letters from Methodist soldiers written to John Wesley. As the readership of these Methodist magazines was primarily interested in the religious aspects of their stories, military details are often vague. The letters of Methodist soldiers only survive as a result of the preservation in the papers of John Wesley. Both the autobiographical articles and letters present problems to historians studying Methodist soldiers in the 1770s. Soldiers writing their autobiographies and letters to religious authorities have a vested interest in presenting themselves in a holy manner. Particularly in the case of the mini-autobiographies, their interest in weighty theological matters may have been added in at a later date. The sources are also remarkable in a number of ways. The letters come directly from the era in question, and though the memoirs are written approximately thirty years after the events they describe, by and large, they were still written before the onset of the French Revolution.

This chapter contributes to two neglected areas in the literature of British soldiers. If historians have neglected studies on soldiers during the wars of the eighteenth century in comparison to modern conflict, the War of Austrian Succession stands out for its lack of scholarly attention in comparison with the rest of these wars. Reed Browning and M.S. Anderson attempted to fill this scholarly gap in the 1990s, but their overviews fail to provide the depth of 
coverage that is available for other mid-eighteenth century wars, such as the Seven Years War. ${ }^{3}$ In a chapter covering the state of the field in 2014, Ciro Paoletti argues that the Seven Years War and American War of Independence continue to dominate the historiography of the eighteenthcentury wars, to the detriment of the War of Austrian Succession, and earlier War of Spanish Succession, to say nothing of the more minor conflicts in this period. ${ }^{4}$ This general trend also proves true for the specific topic of this chapter: British enlisted men, or common soldiers. With the exception of Andrew Cormack's recent social history of the Chelsea Pensioners in the first half of the eighteenth century, and a chapter covering the entire eighteenth century in Michael Snape's Religion and the Redcoat, common British soldiers in the War of Austrian Succession era have received much less attention than their counterparts in the Seven Years War or American War of Independence. ${ }^{5}$

By comparison, Methodism in Britain during the eighteenth century continues to develop a rich, if often popular, historiography. Methodism worked its way into popular culture and army life during the eighteenth century, but in a military context that process has been largely left unexplored. In 2017 Kenneth J. Collins, a professor of historical theology at Asbury Theological Seminary, published a comprehensive bibliography of works relating to Methodism and John Wesley. ${ }^{6}$ There are numerous theological discourses on the particular doctrines of the Methodist faith, and even more numerous popular biographies of John Wesley. Tellingly, however, this bibliography did not contain any works on Methodism and the British Army. More broadly,

\footnotetext{
${ }^{3}$ Reed Browning, The War of the Austrian Succession (St. Martin's: Griffin, 1993); M. S. Anderson, The War of Austrian Succession 1740-1748 (Routledge, 1995).

${ }^{4}$ Ciro Paoletti, "War, 1688-1812," essay, in A Companion to Eighteenth -Century Europe, ed. Peter H. Wilson (Oxford: Wiley Blackwell, 2014), pp. 464-478.

${ }^{5}$ M. F. Snape, The Redcoat and Religion: the Forgotten History of the British Soldier from the Age of Marlborough to the Eve of the First World War(London: Routledge, 2008). Andrew Edward Cormack, "These Meritorious Objects of the Royal Bounty": The Chelsea Out-Pensioners in the Early Eighteenth Century (London: Henry Ling, 2017).

${ }^{6}$ Kenneth J. Collins, A Wesley Bibliography (Wilmore: First Fruits Press, 2017).
} 
historians have attempted to assess the impact of Methodism on British society. E.P. Thompson critically addressed the role of Methodism in combating working-class radicalism in his classic, The Making of the English Working Class, and historians continue to debate Thompson's contributions to understanding Methodism. Thompson's outlook on Methodism, which even included his own family experiences, was decidedly negative. ${ }^{7}$ When looking specifically at the history of the Methodist religious movement, the starting point for the serious researcher remains The Oxford Handbook of Methodist Studies. ${ }^{8}$ David Hempton's study of Methodism and politics is older but still highly instructive. ${ }^{9}$

For Methodist soldiers, Methodism and its practice became an alternative identity to the rough masculinity of military life. These soldiers attempt to reconcile the harsh realities of their soldierly world with their new-found religious sentiments. In fusing these two aspects of their lives, they formed a new soldierly identity based both on military loyalty and religious purity. These men sought to deploy their Methodism as a pro-government ideology, where true adherents would "Fear God and Honour the King." In doing so, they attempted to prove that they were both legitimate soldiers and loyal subjects, indeed, that they were God's chosen people in a particularly British soldierly context. As these Methodist soldiers experienced new birth into a burgeoning religious movement, they also attempted to apply the effects of their transformation of religious feeling in a military setting.

\footnotetext{
${ }^{7}$ E. P. Thompson, Making of English Working Class (London: Victor Gollancz Ltd, 1963); Stephen Heathorn, "E.P. Thompson, Methodism, and the 'Culturalist' Approach To the Historical Study of Religion," Method \& Theory in the Study of Religion10, no. 2 (1998): pp. 210-226; Roland Boer, "EP Thompson and the Psychic Terror of Methodism," Thesis Eleven 110, no. 1 (2012): pp. 54-67.

${ }^{8}$ William J. Abraham and James E. Kirby, eds., The Oxford Handbook of Methodist Studies (Oxford: Oxford University Press, 2009).

${ }^{9}$ David Hempton, Methodism and Politics in British Society, 1750-1850(London: Routledge, 1984).
} 
At the outset, it is important to realize that Methodist soldiers only ever formed a vocal minority within the British Army of this period. Methodist authors reveal societies numbering in the dozens and hundreds spread throughout the British Army, but that army numbered tens of thousands. ${ }^{10}$ Many soldiers in the British Army would have agreed with the sentiments expressed by an anonymous soldier, referred to as "Jack Careless" in Samuel Ancell's description of the great siege of Gibraltar:

Fine talking of God with a soldier, whose trade and occupation is cutting throats: Divinity and slaughter sound very well together, they jingle like a crack'd bell in the hands of a noisy crier: Our king is answerable to God for us. I fight for him. My religion consists in a fire-lock, open touch-hole, good flint, well-rammed charge, and seventy rounds of powder and ball. This is my military creed. Come, comrade, drink Success to the British arms. $^{11}$

Methodist soldiers competed with men like "Jack Careless" for the heart and soul of the British Army. Methodist soldiers were never the "average" British soldier. In light of the sources available to historians working prior to the twentieth century, searching for an "average" soldier is increasingly difficult. Jason Phillips has suggested that as opposed to looking for an average soldier, military historians might be better served by examining groups of soldiers who formulated influential ideologies. ${ }^{12}$ Phillips followed this recommendation with his book, Diehard Rebels, which examined a group of soldiers who refused to accept defeat even as the American Civil War drew to a close. ${ }^{13}$ In this line of thinking, Methodists soldiers became an important minority within the army, as they both attempted to evangelize their beliefs and

\footnotetext{
${ }^{10}$ John Wesley, The Journal of the Rev. John Wesley, A.M., ed. Thomas Jackson, (London: Wesleyan Conference Office, 1869), 1:455.

${ }^{11}$ Samuel Ancell, A Circumstantial Journal of the Long and Tedious Blockade and Siege of Gibraltar from the 12th of September, 1779, to the 23d. of February, 1783, Etc. (Cork: A. Edwards, 1793), 97.

12 Jason Phillips, "Battling Stereotypes: A Taxonomy of Common Soldiers in Civil War History," History Compass 6, no. 6 (2008): 1417-1425

${ }^{13}$ Jason Phillips, Diehard Rebels: The Confederate Culture of Invincibility (Athens: University of Georgia Press, 2010).
} 
formulated pro-government ideologies. Methodist Soldiers also provide an example of a dutiful and professionalized attitude towards soldiering, matching the administrative and organizational efforts of militaries in the eighteenth century. Methodism also provided an opportunity for soldiers to correspond with, and consume new ideas from, leading figures in religious civil society.

\section{THE SPREAD OF METHODISM AND THE RESPONSE OF MILITARY AUTHORITIES}

The Methodist movement grew out of meetings held by John and Charles Wesley at Lincoln College at the University of Oxford in the late 1720s and 1730s. After attempting missionary work among Native Americans in the colony of Georgia, John Wesley felt his "heart strangely warmed" as he attended a Moravian religious service at Aldersgate near London on May 24, 1738. This conversion based upon feeling was a key aspect in Methodist and future evangelical Christian movements. Charles Wesley reported a similar religious experience, and both began a program of open-air preaching. Through the first large-scale Methodist soldier societies cropped up during the 1744 campaign in Flanders, John and Charles Wesley's encounters with soldiers in Britain during 1738 and 1739 laid the groundwork for this spread of religious reform within the army. ${ }^{14}$ Soldiers often flocked to the preaching of John and Charles, but these eager Christians occasionally faced hostility from fellow soldiers, especially when they were led by anti-Methodist officers. Examining the journal of Charles Wesley in the year 1743, we find that he was accosted by a company of soldiers near Sheffield:

The Captain laid hold on me, and began reviling. I gave him for answer, "A Word in season; or, Advice to a Soldier ;" then prayed, particularly for His Majesty King George, and preached the Gospel with much contention. The stones often

\footnotetext{
${ }^{14}$ John Telford, Wesley's Veterans: Lives of Early Methodist Preachers, vol. 3 (Salem, OH: Schmul Publishers, 1912), 13; John Wesley, The Works of John Wesley, ed. W. R. Ward and Richard P. Heitzenrater, Journals and Diaries II (Nashville, TN: Abingdon Press, 1990), 19:19.
} 
struck me in the face. After sermon I prayed for sinners, as servants of their master, the devil; upon which-the Captain ran at me with great fury, threatening revenge for my abusing, as he called it, "the King his master." He forced his way through the brethren, drew his sword, and presented it to my breast. My breast was immediately steeled. I threw it open, and, fixing mine eye on his, smiled in his face, and calmly said, "I fear God, and honour the King." His countenance fell in a moment, he fetched a deep sigh, put up his sword, and quietly left the place. To one of the company, who afterwards informed me, he had said, "You shall see, if I do but hold my sword to his breast, he will faint away." So perhaps I should, had I had only his principles to trust to; but if at that time I was not afraid, no thanks to my natural courage. ${ }^{15}$

Charles also had positive interactions with soldiers. During the height of the Jacobite Rebellion of 1745 he preached to an army camp on November 8, 1745:

Fri., November 8th. I preached first in Bexley church, then in the front of the camp near Dartford. Many of the poor soldiers gave diligent heed to the word. One of the most reprobate was pricked at the heart, and entered the Society.

Sat., November 9th. A regiment passing by our door, I took the opportunity of giving each soldier a book. All, excepting one, received them thankfully. ${ }^{16}$

Methodism was at its peak in the British Army during the War of Jenkins Ear and War of Austrian Succession, when lay preachers and common soldiers actively created Methodist societies throughout the British Army. Michael Snape studies the chronological progress of this revival in detail, in the first chapter of his work, The Redcoat and Religion, to such an extent that this chapter will only cover the revival briefly. Snape also points out that many of these soldiers had already formed religious societies before Methodism took root, and those wartime deployments may actually have facilitated the spread of Methodism in the army. ${ }^{17}$ These Methodist soldier-societies were made up of soldiers who attempted to reject their former way of

\footnotetext{
${ }^{15}$ Thomas Jackson, The Journal of Charles Wesley, May 25 ${ }^{\text {th }}, 1743$.

${ }^{16}$ Ibid. November $8^{\text {th }}-9^{\text {th }}, 1745$.

${ }^{17}$ Michael Snape, The Redcoat and Religion: the Forgotten History of the British Soldier from the Age of Marlborough to the Eve of the First World War (London: Routledge, 2008), 43.
} 
life by abandoning desires and practices they now considered sinful, such as gambling, drunkenness, and sexual liaisons. One such soldier—often identified as one of the founding fathers of the 1740s Methodist army revival, John Haime—outlined the practices of Methodist societies in an angry confrontation with an officer: "I preach against swearing, whoring, and drunkenness; and exhort men to repent of all their sins that they may not perish." ${ }^{, 18}$ In an environment where death was a real possibility, Haime's message may have resonated.

Methodist soldiers, perhaps unsurprisingly, viewed the Anglican chaplaincy in the British Army as both inadequate and an object of suspicion and disgust. Soldier Duncan Wright recalled that "the care four or five regiments [were] left to an unhappy [chaplain] who was an object of common ridicule among the soldiers for his perpetual drunkenness." ${ }^{19}$ Wright surmised that "were the chaplains men of real piety, and courage, much good might be done in the army. ${ }^{, 20}$ Complaints about the chaplaincy by Methodist soldiers continued until the end of the century. ${ }^{21}$ Lacking a dedicated chaplaincy, Methodist soldiers took it upon themselves to organize religious meetings, prayers, and the singing of hymns. They also wrote to, and even met with, leading members of their religious movement, such as John Wesley. John Haime wrote to Wesley reporting the great success in increasing the number of Methodist soldiers with the army: "Our Society has now increased to upwards of two hundred, and the hearers are frequently more than a thousand." ${ }^{22}$ Wesley was overjoyed at Haime's success and carried on a lively

\footnotetext{
${ }^{18}$ Thomas Jackson, The Lives of Early Methodist Preachers: Chiefly Written by Themselves, (London: Wesleyan Conference Office, 1875), 1:284.

${ }^{19}$ John Telford, Wesley's Veterans: Lives of Early Methodist Preachers, (Salem, OH: Schmul Publishers, 1912), 2:33.

22 John Wesley, The Journal of the Rev. John Wesley, A.M., ed. Thomas Jackson, (London: Wesleyan Conference Office, 1869), 1:455.
} 
correspondence with numerous common soldiers in the 1740s. Their letters are full of theological discussions, as well as reports from the battlefield on the progress of the war.

British officers noticed Haime's religious revival and were not entirely impressed. Officers feared that the presence of a new religious faction might prove disruptive in army life. Haime wrote John Wesley in May of 1744: "many say I am mad[.] I have been sent for and examined several times; but, blessed be God, He has always delivered me." ${ }^{23}$ Some British officers often felt that their chaplaincy was not terribly effective in ministering to the spiritual needs of the men, and attended Haime's meetings to support his cause. Other officers considered Haime a dangerous religious radical who would undermine the authority of the command structure. In a stormy meeting with General Sinclair, Haime was accused of a breach of military discipline for coming to Sinclair himself and not sending an officer to represent him. Sinclair then asked, "How came you to preach?” To which Haime replied, “The Spirit of God constrains me to call my fellow sinners to repentance.”24 General Sinclair was not persuaded by Haime’s words and ordered him to stop preaching.

As Haime's story demonstrates, Methodists in the army often found themselves in a strange no man's land between the official tolerance and instances of harsh censure by their officers. Officers who did not like Methodists sometimes tolerated them as a result of the behaviors they practiced. Methodist soldier Duncan Wright of the $10^{\text {th }}$ Regiment of Foot captured this dilemma from the perspective of an officer in his regiment in the 1750s: "Though he did not like Methodists... he wanted us all to be very good... therefore we had very strict

\footnotetext{
${ }^{23}$ John Wesley, The Journal of the Rev. John Wesley, A.M., ed. Thomas Jackson, (London: Wesleyan Conference Office, 1869), 1:455.

${ }^{24}$ John Telford, Wesley's Veterans: Lives of Early Methodist Preachers, (Salem, OH: Schmul Publishers, 1912), $1: 31$.
} 
orders against swearing, drunkenness, etc. ${ }^{25}$ Like many other Methodist soldiers, Wright noted that there was no official position held by officers toward Methodists in the ranks: "Our lieutenant-colonel did not care what a soldier's religion was, provided he did his duty; but our major... to whom the command of the regiment was left for a time, thought it a disgrace to have a sergeant a preacher among them.. ${ }^{26}$ For this major, devout religious belief was seen as detrimental softness in military life. Wright was eventually reduced (down-sized) out of the army at the end of the Seven Years War, as a result of the machinations of this particular officer. Some officers attempted to intercede on his behalf, saying that they "wished I could persuade all their men to be religious, for they had no trouble with the Methodist soldiers. ${ }^{, 27}$ Charles Wesley noted that he managed to convert an officer in $1745 .{ }^{28}$ Methodist soldiers were able to use this inconsistent response among officers over the rise of their religious movement. As confusion reigned among officers, Methodists continued to attract new followers to their cause, and gain contacts with greater authority to safeguard them. Official indecision regarding Methodism led it to become part of the religious fixture of the British Army for the next century.

As a result of the deficiency of the Anglican chaplains, Methodists obtained the opportunity to gain the attention of a member of the British royal family. Haime began a campaign of open protest that chaplains were not administering the sacrament regularly. $\mathrm{He}$ recalled, "I complained aloud in the open camp... the chaplains were exceedingly displeased; but the Duke of Cumberland, hearing of it, ordered that it should be [communion] administered

\footnotetext{
${ }^{25}$ John Telford, Wesley's Veterans, 2:27.

${ }^{26}$ John Telford, Wesley's Veterans: Lives of Early Methodist Preachers, (Salem, OH: Schmul Publishers, 1912), $2: 31$.

27 Ibid, 32.

${ }^{28}$ Thomas Jackson, The Journal of Charles Wesley, November $10^{\text {th }}, 1745$.
} 
every Lord's day[.]"29 This gained Haime notoriety, and eventually, Cumberland requested an interview with the cantankerous Methodist:

The duke, hearing many complaints of me, inquired who I was; if I did my duty, if I would fight, and if I prayed for a blessing on the king and his arms: they told his royal highness, I did all this as well as any man in the regiment. He asked, "Then what have you to say against him? Afterwards the duke talked with me himself, and asked me many questions." He seemed so well satisfied with my answers, that he bade me "go on;" and gave out a general order that I should preach anywhere, and no man should molest me. ${ }^{30}$

An examination of HRH the Duke of Cumberland's orderly book for this period does not provide evidence of Haime's story but shows that there were indeed problems with the established chaplaincy. On May 30, 1745, Cumberland ordered, "The commanding officers of the Regiments whose Chaplains are absent is ordered by H.R.H. to write immediately to those several Chaplains, to repair forthwith to their duty here; without the least delay or excuse." ${ }^{\prime 31}$ The Duke's troubles concerning Chaplains continued into the summer, and Methodists took advantage of this by showing their devotion both to God and the cause of their sovereign. Later in the year, Haime preached a sermon exhorting soldiers to be loyal to their king, a portion of which read:

You fight for a good cause, and for a good king, and in defence of your country. And this is no way contrary to the tenderest conscience, as many of you found at the Battle of Fontenoy; when both you and I did our duty, and were all the time filled with love, and peace, and joy in the Holy Ghost. ${ }^{32}$

Unbeknownst to Haime, the Duke of Cumberland was present in the audience when he delivered this sermon. Although no formal patron-client relationship developed between

\footnotetext{
${ }^{29}$ Thomas Jackson, Lives of the Early Methodist Preachers, 1:290.

${ }^{30}$ John Telford, Wesley's Veterans: Lives of Early Methodist Preachers, (Salem, OH: Schmul Publishers, 1912) 1: 291.

${ }^{31}$ Society of the Cincinnati Library, MSS L2017F30, 54.

${ }^{32}$ Telford, Wesley's Veterans, 1:33.
} 
Cumberland and the Methodist soldiers, Haime subsequently used Cumberland's name in arguments with his superiors, which opened doors that had previously been closed to him. An officer angrily reproached Haime for speaking out of turn, and Haime replied, "I had the liberty of speaking with the Duke of Cumberland. ${ }^{, 33}$ The officer's tone immediately softened. By exploiting friction between absentee chaplains and his army's commander, Haime had secured the Methodists' right to worship within the army. As a result, the Methodist movement continued to grow.

By the mid-1740s, Methodism had spread within the British Army to such an extent that British civilians began to associate the two subjects. The builder we met at the beginning of this chapter, John Nelson, after being converted by the preaching of the Methodist soldier in 1739, became an itinerant Methodist lay-preacher. He eventually ran afoul of townspeople and a recruiting party, which pressed him into military service in an infantry regiment. He was brought before a tribunal of local commissioners, who told him: "You have no license to preach, and you shall go for a soldier." When Nelson protested this decision, one commissioner, laughingly said that he was, "fit to go for a soldier, for there [Nelson] might have preaching enough."34

Nelson's description of his imprisonment at the hands of military officials is decidedly biblical. His jailors are diabolical; his judges are described as "Egyptians." When he was actually sent to a marching regiment, however, his story began to change: "The officers bade them march us off to Hepworth Moor, to learn the exercise of a soldier; but Corporal W. seemed as tender to me as if he had been my own father. ${ }^{, 35}$ As it turned out, the corporal was a religious man himself. Nelson was sent to York, where he continued to preach as a soldier and, like the other

\footnotetext{
${ }^{33}$ Ibid, 31.

${ }^{34}$ Telford, Wesley's Veterans, 3:106.

${ }^{35}$ Ibid, 122.
} 
Methodists we have encountered, found the military hierarchy divided on what to do with him. He reprimanded younger officers for swearing; in return, they had him confined and beaten. His Major, however, found that his preaching was, "no crime; for when you have done your [military] duty I do not care if you preach every night... you may go home to your quarters, and... I may send for you and hear you myself... for I wish all men were like you." ${ }^{36}$ This officer's sentiment indicates that he found Methodist soldiers easier to manage, and that they presented less problems for army control than men who possessed no religious feeling.

Far from only being popular with officers, Nelson also fortunately found friends among his fellow soldiers. These men, whether from sincere religious feeling, or amusement that a meek Methodist preacher had been forced to join them in the army, often attempted to make life easier for him. While marching to Durham, he noted, "I was much surprised at the good-nature of the soldiers in all this march; for I believe twenty offered to carry the gun for me, or anything else I had. ${ }^{37}$ Thanks to the intercession of Charles Wesley, the Earl of Stair obtained discharge papers for John Nelson. Charles noted in his diary: "Toward the end of my discourse at the chapel, Mr. Erakine was sent to receive a soldier brought by William Shent to redeem John Nelson. He immediately took him to Lord Stairs, and got a discharge for John Nelson. ${ }^{38}$ With his freedom secured by the patronage of Charles Wesley and Stair, Nelson preached to the officers and soldiers of his regiment one final time. Nelson's Major told him, "I wish you well wherever you go: for I believe you Methodists are a well-meaning people. ${ }^{39}$ His fellow soldiers heard him preach one final time, and told him that, "We are glad you are set at liberty, but sorry to part with

\footnotetext{
${ }^{36}$ Telford, Wesley's Veterans, 3:135-136.

${ }^{37}$ Ibid, 140.

${ }^{38}$ Jackson, The Journal of Charles Wesley, May $25^{\text {th }}, 1743$.

${ }^{39}$ Telford, Wesley's Veterans: 3:152.
} 
you." ${ }^{, 40}$ As Methodist societies increased their following in the army, Britain was faced with its most dangerous foreign policy challenges of the mid-eighteenth century: the War of Austrian Succession and Jacobite Rebellion of 1745.

METHODIST CONVERSIONS AS AN EMOTIONAL EXPERIENCE IN THE BRITISH ARMY

Most of the narratives of Methodist soldiers are conversion narratives, written for the benefit of a Methodist audience long after the events they describe. The great similarities in the narratives, however, suggest that an accepted idea of a standard Methodist conversion appeared during the War of Austrian Succession. The Methodist soldiers wrote openly regarding their emotional conversions, and though most of these conversion narratives are formulaic, historians should carefully examine the emotional language soldiers used to describe their conversions. Almost all of these narratives follow a pattern. In the opening, the soldiers were unrepentantly dominated by sinful activities such as swearing, drinking, gambling, and fornication. Soldiers wrote openly about this sin. John Haime noted, "I was very undutiful to my parents, and much given to cursing, swearing, lying, and Sabbath-breaking," and continued, "If at any time I grew uneasy again, I stifled it by drinking, swearing, card-playing, lewdness, and the like works of darkness, which I then pursued with all greediness." 41 Sampson Staniforth recorded, "I was now fast bound with the chains of sin, filled with unholy desires, and, as often as occasion offered, bringing them into practice." ${ }^{42}$ Staniforth particularly emphasized the committed nature of this bad behavior: "And I had not the least remorse for any of the sins I was daily committing; I now got into bad company, and by their advice and encouragement ran into open wickedness, gaming

\footnotetext{
${ }^{40}$ Ibid.

${ }^{41}$ Jackson, The Lives of Early Methodist Preachers: 1: 269, 270.

${ }^{42}$ Jackson, The Lives of Early Methodist Preachers: 4: 110.
} 
in particular to the great disadvantage of my master, and the great sorrow of my parents." ${ }^{43}$ Duncan Wright had the audacity to blame his mother for his sinful ways: "my mother, being too easy and indulgent, let us have our own way, which led us to all the follies and sins we were capable of." ${ }^{44}$ Soldiers later recalled that this sinful activity sunk them into a deep depression, because they could not stop the patterns of behavior they had begun.

To make matters worse, many of these soldiers reported that once their sinful activity had developed, they were frequently contacted by Satan himself. John Haime explained that the devil actively tried to keep him from God: "thought everyone happy but myself; the devil continually telling me, there was no mercy for me." ${ }^{45}$ Often, the devil appeared and tempted the soldiers when they had just begun to leave their sins behind. Upon visiting a church, Haime recalled that, "it was as much as I could do to avoid blaspheming aloud. Satan suggested, 'Curse him! curse him!' perhaps a hundred times. My heart has often replied, 'No! no! no!' Then [Satan] suggested,' Thou hast sinned against the Holy Ghost. ${ }^{, 46}$ Other soldiers repeated this narrative, such as drummer John Dillon: "I had not continued in this joy many days when Satan came upon me like a flood, charged me afresh with all my sins, and told me, there was no possibility of my being saved." ${ }^{47}$ These struggles with the devil are interspersed with long passages which recount a desire to become holy followed by lapses back into sin. In some cases, this see-saw battle for the soldier's soul can last scores of pages. Eventually, though, soldiers reached a critical moment, often after meeting with an Anglican or Methodist minister.

\footnotetext{
${ }^{43}$ Ibid.

${ }^{44}$ Telford, Wesley's Veterans:, 3:18.

${ }^{45}$ Jackson, The Lives of Early Methodist Preachers, 1: 270.

${ }^{46} \mathrm{Ibid}, 273$.

${ }^{47}$ John Dillon, A Short Account of Mr. John Dillon, Preacher of the Gospel. Written by Himself (London: Printed for G. Whitfield, 1796), 6.
} 
Soldiers' narratives climaxed in the story of God's love breaking through to the heart of these soldiers. In describing their emotions during this process, soldiers used imagery from the scriptures, particularly the passage of the Old Testament where Moses brings forth water from a rock. Methodist soldiers experienced intense emotions during these conversions, and often used the symbolism of water from stone to complement stories of their tears during conversion. John Haime reported that, ""But, April 22nd, the Lord showed me that I did not live as became the Gospel of Christ : I was greatly ashamed before God...I prayed earnestly to God that He would smite the rock, and cause the waters to flow." ${ }^{48}$ Haime's request for spiritual awakening led to literal tears: "He answered my prayer. My head was as waters, and my eyes as a fountain of tears. I wept, I sang; I had such a sense of the love of God as surpasses all description." ${ }^{49}$ Sampson Staniforth echoed this story when describing his own conversion, even using the same symbolism: "I could shed tears for nothing ; but now the rock was rent; a fountain was opened, and tears of contrition ran plentifully down my cheeks. A cry after God was put into my heart, which has never yet ceased, and, I trust, never will. ${ }^{, 50}$ This open weeping signified a sincere repentance, and also was the first sign of a heightened emotional state found across Methodist writings.

John Evans, a soldier whose writing only survives because John Wesley recorded his letters, explained that at his moment of conversion:

My eyes overflowed with tears of love. I knew I was, through Christ, reconciled to God, which inflamed my soul with fervent love to him, whom I now saw to be my complete Redeemer. ' $\mathrm{O}$ the tender care of Almighty God in bringing up his

\footnotetext{
${ }^{48}$ Jackson, The Lives of Early Methodist Preachers: 1:278.

${ }^{49} \mathrm{Ibid}$.

${ }^{50}$ Ibid, 4: 118.
} 
children! How are we bound to love so indulgent a Father, and to fall down in wonder and adoration of his great and glorious name, for his tender mercies! ${ }^{51}$

Evans felt such emotion during his conversion experience that he wept, and many other Methodist soldiers experienced similar emotions. Upon realizing that his sins were grieving God, Duncan Wright was emotionally shattered: "my slighting of Christ... and grieving the blessed Spirit, melted my heart, and made my eyes a fountain of tears. ${ }^{152}$ Methodist soldiers described the emotional experience of their conversion process, and emphasized this process as one of the most emotional in their life stories.

Taken together, these conversion experiences indicate that whether accurately, or for the benefit of a Methodist reading audience, soldiers were quite unhappy prior to their conversion to Methodism. They pursued activities quite common in militaries of the time and felt shame as a result of societal judgments regarding these sinful actions. In converting to Methodism, soldiers sought solid escape from these vices, combined with a new communal accountability provided by their fellow-soldier Methodists. As discussed in chapter two, British soldiers often left their village communities in dubious circumstances, creating a rift with those left behind. Multiple soldiers attempted to use their Methodist conversion as a way of demonstrating remorse for their actions and showing their desire to be reconciled with friends and loved ones at home.

\section{METHODIST SOLDIERS' FAMILY RELATIONSHIPS AND VIEW OF GOD}

Methodist soldiers carefully explained the way that Methodist faith had changed their relationships with their family and local communities. Duncan Wright believed that his preconversion lifestyle had caused his mother a great deal of sorrow. ${ }^{53}$ John Haime, growing up in

\footnotetext{
${ }^{51}$ John Wesley and John Emory, ,The Works of the Reverend John Wesley, A.M, vol. 3 (Methodist Book Concern, 1839), 324.

${ }^{52}$ Telford, Wesley's Veterans:, 2:21.

${ }^{53}$ Ibid, 19.
} 
Dorset, noted that his wicked behavior caused his parents much grief. He explained, "I was very undutiful to my parents, and much given to cursing, swearing, lying, and Sabbath-breaking.".54 His loose living also prevented him from staying employed in his uncle's business in the long term. ${ }^{55}$ Sampson Staniforth left his home town of Sheffield to join the British Army,. His local community mourned his departure, but Staniforth recalled only his bitterness towards them: "All my friends were in tears; but it made no impression on me. ${ }^{, 56}$ Likewise, Staniforth recalls being chased through Perth by his lover's male family members (who were soldiers of the Royal Highland Regiment), after it came to light that they were expecting a child, and that Staniforth had no intention of marrying the young woman. ${ }^{57}$ This reprobate behavior changed after Staniforth was converted by the preaching of John Wesley, John Haime, and William Clements. After his conversion, he recalled, "About this time I began to think of my parents and family... I now sent [my mother] a long letter, asking pardon of my father and her for all my past disobedience, and telling them that God, for Christ's sake, had forgiven me all my sins. I thanked her for what she had done for me. ${ }^{, 58}$ Likewise, after meeting his future wife at a Methodist sermon, Staniforth married her on June 12, 1746, and appeared to be still happily married when he wrote his narrative thirty-seven years later. ${ }^{59}$

As part of a new non-conformist movement, Methodists' conversion narratives often emphasized attributes of God which often played a role in conversion experiences, primarily God's love and forgiveness. Though Methodists fully acknowledged the power of God, their writings emphasized a God of love. John Dillon recalled attending a sermon, and being moved

\footnotetext{
54 Jackson, The Lives of Early Methodist Preachers: 1:269.

${ }^{55} \mathrm{Ibid}, 270$.

${ }^{56}$ Thomas Jackson, The Lives of Early Methodist Preachers: 4:112.

${ }^{57}$ Ibid, 113.

${ }^{58} \mathrm{Ibid}, 124$.

${ }^{59}$ Ibid, 133-146.
} 
when the preacher explained: "all manner of sins shall be forgiven unto man, only let him come to Christ." ${ }^{60}$ Dillon likewise that during his prayers he cried out, "And now, O Lord God of love, look down in mercy upon me the meanest and weakest of all ; by thy free grace saved thus far, and save me." ${ }^{61}$ Indeed, Dillon references the love of God eight times in his twelve-page narrative, while only referencing the power of God once. ${ }^{62}$

In contrast to their conversion narratives, Methodist soldiers' letters are full of references to the power of God, particularly his power to save them on the battlefield. After the Battle of Fontenoy, William Clements wrote to John Wesley, "the Lord took away all fear from me, so that I went into the field with joy." 63 John Haime, describing the same battle, informed John Wesley, "As to my own part, I stood the fire of the enemy for above seven hours: then my [personal] horse was shot under me, and I was exposed both to the enemy and our own horse [cavalry]. But that did not discourage me at all; for I knew the God of Jacob was with me." ${ }^{64}$ In narrative form, Methodist soldiers emphasized God's love and forgiveness, but in their letters, during the immediate hardships of military life, they appeared much more interested in God's power to protect them from bodily harm.

\section{DIVINE PROTECTION IN COMBAT AS A CONVERSION STRATEGY}

Methodist soldiers used the experience of battle for their own ends. They viewed battle not simply as a time for fatalism, but as an opportunity to display to their officers and fellow soldiers what type of Christians they were. For these men, battle became a performative experience, through which they could demonstrate the sincerity of their religious convictions

\footnotetext{
${ }^{60}$ Dillon, A Short Account of Mr. John Dillon, 6.

${ }^{61}$ Ibid, 12.

${ }^{62}$ Ibid, 8, 11, 12.

${ }^{63}$ John Wesley and John Emory, ,The Works of the Reverend John Wesley, A.M, 3: 360.

${ }^{64}$ Ibid, 361.
} 
through the lack of fear they felt at the prospect of death. By demonstrating not fatalism but contentment, or even joy, in combat, Methodist soldiers performed their faith for all to see, and hoped to win converts to their societies. Just before the Battle of Fontenoy, Sampson Staniforth indicated that he had, "stepped out of the line, threw myself on the ground, and prayed that God would deliver me from all fear, and enable me to behave as a Christian and good soldier." ${ }^{\text {,65 This }}$ type of language fills the writings of Methodist veterans. Another was heard shouting in the midst of battle, “O, how happy I am!"66 John Evans, a Methodist private soldier in the English artillery, was mortally wounded and yet continued to praise God, attempting to use his religious fervor to convert the soldiers around him. ${ }^{67}$ Soldier William Clements reported in a letter describing the Battle of Fontenoy, "the Lord took away all fear from me, so that I went into the field with joy. The balls flew on either hand, and the men fell in abundance... but I scare knew whether I was on earth or in heaven. It was one of the sweetest days I have ever enjoyed.",68 Sentiments like this make it clear that Methodist soldiers viewed battle as a type of paranormal experience, where the hand of God could be decisively felt, and his judgment could be delivered immediately. During the Battle of Fontenoy, John Haime was confronted by an officer of his regiment, who in response to the carnage around him literally asked, "Haime, where is your God now?" ${ }^{69}$ Haime then reports that a cannonball came and struck off the doubting officer's head. Such a story may seem to defy reality, but what really matters is that Haime viewed battle as a transcendent experience where such divine judgment could be possible. Haime continued, "I have seen many good and glorious days, with much of the power of God; but I never saw more

\footnotetext{
${ }^{65}$ Telford, Wesley's Veterans, 1:78.

${ }^{66}$ Ibid, 80.

67 Anonymous, The Arminian Magazine (London: J. Fry \&, 1778), 280.

${ }^{68}$ John Wesley, The Journal of the Rev. John Wesley, A.M., 1:511.

${ }^{69}$ Telford, Wesley's Veterans, 1:34.
} 
of it than this day." ${ }^{, 70}$ Considering the incredibly graphic nature of the battlefield as described above, Haime's elevated experience was a natural response to the horror and chaos of combat. ${ }^{71}$

In the British army, as a result of the relatively small number of Methodists, these displays of religious fervor took on a performative aspect, in order to evangelize to fellow soldiers, and give confidence to the performer and his peers. These religious displays went beyond fatalism: they were designed to encourage other soldiers to embrace Christ. As his regiment lay under fire at the outset of the Battle of Lauffeld, Sampson Staniforth recalled, "while we lay on our arms, I had both time and opportunity to reprove the wicked. And they would bear it now." ${ }^{, 72}$ Using the fear of battle as a motivator, Staniforth made statements against what he viewed as wicked living. Methodists soldiers also boasted regarding their fearlessness under enemy fire and believed that this was a sign of their righteousness. John Haime recalled meeting a badly wounded Methodist, whom he asked, "Have you got Christ in your heart?" The Methodist soldier replied, "I have, I have had Him all this day." ${ }^{73}$ Methodist preachers attempted to instill this fearlessness in their soldiers. Before British troops marched off to confront the Jacobites during the 1745 Jacobite Rebellion, Charles Wesley noted that he prayed over soldiers, “... and solemnly commended them to the grace of God, before they set out to meet the rebels. They were without fear or disturbance, knowing the hairs of their head are all numbered, and

\footnotetext{
${ }^{70}$ Ibid.

${ }^{71}$ Yuval Noah Harari has addressed the way in which soldiers presented combat as "the ultimate experience" in the eighteenth century. The descriptions of Methodist veterans fit well into that paradigm. See Yuval Harari, Ultimate Experience: Battlefield Revelations and the Making of Modern War Culture, 1450-2000 (London: Palgrave Macmillan, 2014).

${ }^{72}$ Telford, Wesley's Veterans, 1:90.

${ }^{73}$ Ibid, 34.
} 
nothing can happen but by the determinate counsel of God." ${ }^{, 74}$ Fearlessness in the face of death, these preachers and soldiers believed, demonstrated the validity of their religious beliefs.

This fearlessness in the face of death could even occur off the battlefield. Duncan Wright employs this thinking while comforting a soldier slated for execution in September of 1758. This soldier, Joseph Newton of Derbyshire, was a deserter. Unlike many instances of execution for desertion which were commuted by eighteenth-century commanders, the government had decided to make an example of Newton and other soldiers across Ireland by not commuting their sentences. ${ }^{75}$ Wright began to minister to this man a week before his execution was scheduled to occur and converted him to Methodism. The Thursday before his execution, Wright notes, "his soul was set at liberty. From that time he witnessed a good confession to all that spoke to him. Everyone that saw him to the place where he was shot could not but admire the serene joy that appeared on his countenance." ${ }^{, 76}$ Wright was particularly impressed that "his calm, happy death made a deep impression on many of our soldiers; for they could not but discern the difference between him and [another soldier] they saw die awhile before at Dublin, who showed the greatest reluctance. ${ }^{, 77}$ Wright attaches great importance, not to the fatalistic acceptance of death and hope for spiritual rebirth on the part of Newton, but rather, the power it had to impress other soldiers. Fatalistic bravado was not merely a tool of battlefield motivation, but a tool which had the potential to win many converts for Methodist societies.

For the Methodists, being fearless or even joyful in the face of death gave them the opportunity to display their loyalty to their faith, and potentially convert new members for their

\footnotetext{
${ }^{74}$ Jackson, The Journal of Charles Wesley, November $11^{\text {th }}, 1745$.

${ }^{75}$ For an excellent example of this practice of commuting sentences, see the orderly book of HRH the Duke of Cumberland from April to October of 1745: Society of the Cincinnati Library, MSS L2017F30.

${ }^{76}$ Telford, Wesley's Veterans, 2:26.

${ }^{77}$ Ibid.
} 
societies. The Methodist soldiers then faithfully reported their actions to leading Methodists such as Wesley, explaining to him that displays of such devotion before the enemy had, "made the officers, as well as common soldiers, amazed: and they acknowledge it to this day." ${ }^{, 78}$ British Methodist soldiers combined their religious calling and place within the British military as a means of performing their religious devotion, impressing the world around them, and corresponding with the leading figures of their religious movement.

The tales of battlefield devotion displayed by Methodist soldiers made their way back to John Wesley via letters, as I discussed above and quote here. At home, Wesley then used those same stories in order to both gain favor with authorities and continue his open-air preaching. In October of 1745 , Wesley travelled to Doncaster, in order to preach to a camp of soldiers there. In order to gain permission to preach, he wrote the governor, Matthew Ridley, describing the bravery of Methodist soldiers in Flanders, the wounds they suffered on the battlefield, and their religious devotion. Describing the death of Methodist soldier John Evans, Wesley argues that Evans, for as long as he was able, exhorted his fellow soldiers to, "Fear God and Honour the King." ${ }^{, 79}$ Wesley was able to use descriptions of Methodist soldiers' performance in battle to justify his preaching to secular authorities, and continued to particularly prioritize soldiers as a target for his religious instruction.

\section{ARMY METHODISM AFTER 1748}

Though Methodist activity in the army reached its height in the 1740s, Methodist soldiers continued to be active in the army after the great Methodist revival. Although fewer diarists in the Seven Years' War era show the strong influence of religious sentiments, we should carefully

\footnotetext{
${ }^{78}$ John Wesley, The Journal of the Rev. John Wesley, A.M., ed. Thomas Jackson, 2:2.

${ }^{79}$ Wesley, The Journal of the Rev. John Wesley, ed. Thomas Jackson, 1:502.
} 
note that this community of deeply religious British soldiers endured into that era. Methodist minister Samuel Walker created a strong Methodist society within the 58th Regiment of Foot at Truro during the Seven Years' War era. According to the nineteenth-century editor of Walker's papers:

A great alteration, however, took place; punishments soon diminished and order prevailed in the regiment, to a degree never before witnessed, and the commander at length discovered the excellent cause of this salutary change. Genuine zeal had now its full triumph and its rich reward - the officers waited on Mr. Walker in a body, to acknowledge the good effects of his wise and sedulous exertions, and to thank him for the reformation he had produced in their ranks. ${ }^{80}$

One of the soldiers wrote a letter to Reverend Walker after the 58th Regiment left Truro, confirming these sentiments:

I judge no man: many would desire to die the death of the righteous, that would not desire to live their life; and [I] know that has been my case. Serjeant Moore for ever blesses the day that ever he saw Truro, and we both hope in the Almighty God to see it again, and to hear the glad tidings of salvation as formerly. ${ }^{81}$

During the Seven Years' War, particularly in Ireland, Methodism continued to spread in the British Army. During a trip to Canterbury in February of 1756, John Wesley noted, "an abundance of soldiers and many officers," came to hear him preach. The next day, he had a meal with a colonel, who said, "No men fight like those who fear God: I had rather command five hundred such, than any regiment in his Majesty's army." ${ }^{82}$ Likewise, nearly a year later, in 1757 , Wesley noted:

I went with T. Walsh to Canterbury, where I preached in the evening with great enlargement of spirit; but with greater in the morning, being much refreshed at the

\footnotetext{
${ }^{80}$ Edwin Sidney, The Life, Ministry, and Selections from the Remains of the Rev. Samuel Walker. (London, 1838), 153.

${ }^{81}$ Ibid, 157.

${ }^{82}$ John Wesley and John Emory, ,The Works of the Reverend John Wesley, A.M, 3:623.
} 
sight of so large a number of soldiers. And is not God able to kindle the same fire in the fleet which he has already begun to kindle in the army? ${ }^{83}$

Indeed, Methodism continued to be such a potent force in the British Army that in 1759, Sir Robert Nugent urged William Pitt to use John Wesley (and George Whitefield) as a recruiting tool for the British Army, since Methodism continued to attract soldiers to the army. ${ }^{84}$ Duncan Wright enlisted in the $10^{\text {th }}$ Regiment of Foot in 1754 in Ireland at the outset of the Seven Years War. He spent the entirety of the war in Ireland, marching to threatened parts of the country and putting down riots. In the course of his time in the $10^{\text {th }}$ Regiment of Foot, he saw John Wesley and Thomas Walsh preach and eventually resolved to become a Methodist preacher himself. ${ }^{85}$

By the time of the American War of Independence, soldiers' memoirs contain language giving their overt religious affiliation. Don Hagist has uncovered previously unknown and unpublished material on the most famous British common soldier of this era, Roger Lamb. Further examination of this material makes it clear that Lamb was a Methodist. If he did not date his conversion until May 16, 1786, it is clear he had encountered Methodists before that time. Upon returning to his native Ireland, Lamb was confronted by the preaching of Methodists in Dublin: "it pleased the Lord by the ministry of the Methodist preachers to convince me of sin, righteousness and judgment, the thoughts of death and eternity filled me with fear." Lamb continued, "I should have remarked that while in the Army I was a most extraordinary sinner. I had almost filled up the measure of my iniquities. ${ }^{, 86}$ Though it occurred after his discharge, his conversion was a result of military networks. Lamb recalled, "Quarter Master Burgess (of the first Regiment of horse) who is now a Methodist preacher, was at that time in Dublin. He was a

\footnotetext{
${ }^{83}$ Ibid.

${ }^{84}$ Michael Snape, Religion and the Redcoat, 63.

${ }^{85}$ Telford, Wesley's Veterans, 2:106.

${ }^{86}$ National Army Museum London, 2010-11-16, 144.
} 
nursing father to me, he frequently followed, advised, and instructed me." It seems this soldier was largely responsible for Lamb's conversion, and he recalled, “[Burgess'] temper and upright walk had a good effect on my mind." ${ }^{87}$ The British Army had become a site of conversion and spread of Methodism.

Even after his discharge from the military, Lamb defended his Methodist co-religionists to suspicious military officers. Lamb petitioned General William Henry Clinton, Quartermaster General of Ireland, at the turn of the century. William Henry Clinton was the son of Lt. General Henry Clinton, whom Lamb had served in America. Lamb traveled to Clinton's office on the recommendation of General Calvert and Colonel Mackenzie and met with the younger Clinton. In a scrapbook, Lamb recorded notes on the conversation. After confirming his recommendation, Clinton asked Lamb about his current employment, as a teacher in a Methodist school on Whit Street in Dublin. At the suggestion that he should be appointed to Hibernian school, Lamb asked, "But I hope my being a Methodist would not disqualify me for holding a military or civil situation under government[?]" Clinton responded, "Indeed, Mr. Lamb, I think that every man should choose the best religion he could, nevertheless, I think the Methodists carry religious matters too far." ${ }^{88}$ Lamb, not content to let the slight to his religion rest, replied, "[G]ive me leave to say, sir, that I know the Methodists are very loyal to his Majesty's person and government." ${ }^{89}$ Although his Methodism proved an impediment gaining government employment, Lamb was able to secure status as an out-pensioner from the Chelsea hospital as a result of the patronage he enjoyed, and the devotion he displayed as a Methodist loyalist. ${ }^{90}$

\footnotetext{
${ }^{87}$ Ibid.

${ }^{88}$ Ibid, 114 .

${ }^{89}$ Ibid, 128

${ }^{90}$ Ibid, 134.
} 
Thomas Cranfield, who enlisted in the 39th Regiment in August 1777, also recorded his story of religious conversion. Just before deployment to Gibraltar, Cranfield entered a church on Sunday morning, "prompted by curiosity... The word, under the guidance of the Holy Spirit was brought powerfully home to his mind, so that he became convinced of sin, and of the necessity of salvation through the Redeemer." This conversion experience prompted him to learn to read, and he recorded that he had soon met "with very good friends, who give me good advice." 91 During the American War of Independence, once again, there was little interest in the work of chaplains among the soldiers, but that a small but significant minority of devout soldiers continued to minister to the spiritual needs of the British army. In April 1775, John Wesley noted that his preaching resonated particularly with the officers of the Royal Highland Regiment. Officers had previously ordered soldiers to attend Wesley's sermons in April 1778. In August 1782, while preaching in Plymouth, John Wesley was surprised when: "A little before I concluded, the Commanding Officer came into the Square with his regiment; but he immediately stopped the drums, and drew up all his men in order on the high side of the Square. They were all still as night; nor did any of them stir, till I had pronounced the blessing." 92 This example suggests that not only did Methodism survive in the ranks, as the century continued it was increasingly endorsed by officers.

Methodism would stay with the British Army off and on the battlefield into the Napoleonic era. ${ }^{93}$ Soldiers continued to benefit from many of the same factors which had facilitated its rise in the first place: the most important being officers' confusion about how to react to the growth of Methodism. The most famous British Army officer from this era, Arthur

\footnotetext{
${ }^{91}$ Richard Cranfield, The Christian; a Memoir of Thomas Cranfield (Religious Tract Society, 1844), 12.

92 John Wesley, The Works of the Rev. John Wesley in Ten Volumes, (New York: J.J. Harper, 1826), 4:98.

${ }^{93}$ Michael Snape, Religion and the Redcoat, 138-150.
} 
Wellesley, the Duke of Wellington, originally shared John Wesley's last name but was no lover of the Methodist movement. In 1811, he wrote to the Adjutant-General, Sir Harry Calvert: "Methodism is spreading very fast in the army... the meeting of soldiers... to sing psalms or hear a sermon read by one of their comrades is, in the abstract, perfectly innocent[.]" However, he also hoped that a dedicated chaplain might convince these Methodists to abandon their meetings, or "prevent them from becoming mischievous." ${ }^{94}$ For the Anglican Wellesley, the intense religious feelings of the non-conformist Methodists would present a problem to the orderly management of the army. Other officers would yell and curse at Methodist soldiers, much as they did in the 1740s. ${ }^{95}$ Methodism was neither officially sanctioned or repressed, and as a result continued to play a role in army

\section{COMMEMORATION OF METHODIST SOLDIERS}

Sampson Staniforth, after having survived the grim battles of the War of Austrian Succession, lived to a relatively old age. Upon his death, the Methodist Magazine published a poem, imaginatively describing Staniforth's experiences in both military and religious worlds:

Sampson in youth-like the unbroken steed-

With British soldiers, ranked in flaming red, To Flanders marched to meet the Gallic foe:Twas there the youth first learned himself to know.

Back to his native country he returns;

A different flame now in his bosom burns.

Discharged from Royal William's loyal band, Enlists in Jesu's nober ranks to stand.

No changeling he-firm in his Master's cause; A Bible-Christian, subject to its laws; A soldier, husband, Christian, man of worth, Such died the venerable Staniforth. ${ }^{96}$

\footnotetext{
${ }^{94}$ Antony Brett James, ,Wellington at War: a Selection of His Wartime Letters(Simon Fraser University, 1989), 213214.

${ }^{95}$ Michael Snape, Religion and the Redcoat, 150.

${ }^{96}$ Anonymous. The Methodist Magazine for the Year 1799, being a continuation of the Arminian Magazine, (London: G. Whitfield, 1799) 608.
} 
Published in the last decade eighteenth century, the poem demonstrates a particular type of commemorative culture, one which valued soldiers who were both martial and religious. The list of Staniforth's accomplishments is particularly important. According to the poet, he was a "soldier, husband, Christian, man of worth." In addition to providing a convenient rhyme, the list connects many portions of Staniforth's identity: military, local and familial, religious, and social values are all bound up in the description of Staniforth's legacy. Indeed, one can view the publication of all Methodist soldiers' memoirs, which proceeded during the late eighteenth and early nineteenth centuries, as an act of commemoration. The fact that many of the early stories of the Methodist soldier-preachers were published in the 1780s and 1790s gives us a sense that Methodism was growing in strength in Britain as a whole, and that it was becoming easier for soldiers to integrate religious and martial identities. Despite the words of "Jack Careless," divinity and slaughter were increasingly discussed and practiced by the same men in the eighteenth century.

\section{CONCLUSION}

This examination of the experience of Methodist soldiers in the British Army teaches us several significant lessons about soldiers in the eighteenth century. First, Methodist soldiers remind us, as Don Hagist has recently asserted in studying the American War of Independence, that there was not one experience for common soldiers, but a wide diversity of possibilities and experiences. ${ }^{97}$ Second, Methodism in the army demonstrates one way in which soldiers remained deeply connected to civil society, and even submitted to the authority and guidance of civilian religious figures. Methodism kept these men with one foot in civilian life through their

${ }^{97}$ Don Hagist, Noble Volunteers: The British Soldiers who Fought the American Revolution, (Yardley: Westholme, 2020). 
connection to other Methodists. Third, in some cases, Methodism provided the push for men to become rehabilitated with their local communities, by demonstrating repentance for the actions which had led them to join the army in the first place.

Methodists benefited from a confused official response to their religious message in the battle for the soul of the British Army. The lack of official repression (as well as small signs of approval from some officers) allowed Methodism to survive in the army. They made powerful patrons by demonstrating their dedication to good behavior and loyalty to the crown. As Methodist soldiers went to battle, they displayed fearlessness which they believed would win new converts to their faith. For them, battle became an elevated realm where God's judgment could be instantly dispensed, and they could demonstrate their devotion to God. Tales of this battlefield courage were used by Methodist preachers like John Wesley to further the spread of Methodism away from the battlefield. Far from being a phenomenon local to the War of Austrian Succession, Methodism continued to play a role in army life from the end of the War of Austrian Succession into the Napoleonic era. As Methodist soldiers negotiated their position within the British army, in Prussia, a similar religious movement had already gathered strength and official sanction. The agreement reached between Halle Pietists and Prussian King Frederick William I of Prussia allowed Pietism to become what Methodism was not: a communal religious experience in which most soldiers took part. 


\section{"God and King": Religious and Monarchical Thinking in the Prussian Army, 1740- 1786}

Popular memory provides historians with a multitude of famous scenes involving the Prussian Army and the Seven Years War, but perhaps none more famous than the "Chorale von Leuthen," when the Prussian Army, having defeated the Austrians near Schloss Lissa in December 1757, crunched their way across the ice to their encampment while singing the 1636 Hymn of Lutheran minister Martin Rinket, Nun Danket alle Gott (Now thank we all our God). Seized upon by generations of propagandists and filmmakers, this image of pious soldiers singing hymns has become indelibly intertwined with stereotypical images of the Prussian Army. In focusing on the devotion of Prussian soldiers and their songs, historians have often forgotten the important role that monarchical power played in this same ideology. Another Prussian soldier's song ends on this note:

Es konnt nich sein, Gott legt sich drein, Thut unsern König beschützen allein, Durch seine Macht, hat so weit bracht, $\mathrm{Da} \beta$ er die Feinde itzt alle auslacht.
It cannot be, that God therein allows, Our King alone protection from blows, Through His Power, we bend the bow, And he is laughing at the foe. ${ }^{1}$

This soldier's song clearly connects the royal person of Frederick II with the divine authority of

God, protection against harm, and a belief in the defeat of the enemies of the Prussians state.

Other verses of the same song proudly proclaim, "We know the enemy's hand, and they shall not be spared, because of all them wanted to bring down the House of Prussia."2 Thus, as Prussian

\footnotetext{
${ }^{1}$ Franz Wilhelm von Dittfurth, Zehn Schöne neue Lieder aus dem Siebenjährigen Kriege, (Berlin: Trowisch und Sohn, 1851) 6. This is a translation designed to preserve the rhyme in English. A more literal rendering might be: "It cannot be that God allows therein, our King to be struck alone, By his Power, we have come far, That he might laugh at all the enemies."

${ }^{2}$ Ibid.
} 
soldiers marched to and from the conflicts of the Seven Years War, they sang not only of the love and power of God, but combined those attributes with the person of their monarch.

Frederick was not afraid to employ these sentiments, combined with his own leadership style, to his advantage. Historians have often described the presentation of Frederick in the Seven Years War. Frederick's uniforms, some of which have survived to the present, appear as plain, worn, and snuff-encrusted. The king's worn appearance was part of a wider system of rituals that enabled him to remain a holy and paternal symbol of firm leadership and benevolence for Prussian enlisted men. The king cultivated himself as a positive yet distant symbol. He appeared in his soldiers' world but was not a familiar enough figure to inspire criticism or contempt. A recent English-language biography of Frederick, by historian Tim Blanning, argues that "for all his snobbery and contempt for humanity, Frederick showed a sharp awareness of the need to cultivate an intimate bond with his army." ${ }^{3}$

This chapter examines the religious and monarchical ideologies that motivated Prussian common soldiers during the Seven Years War. It argues that Prussian soldiers relied heavily on religious beliefs when attempting to make sense of their lived experiences during this war. As their letters demonstrate, Prussian soldiers believed that a loving and powerful God protected them and their families during this time of crisis. Second, the chapter argues that Frederick II formed an important part of his soldiers' worldview, and he deliberately cultivated his image for his soldiers. The king used Prussian soldiers' loyalty to family and village connections, crafted a mass-produced familiarity with his men, and benefited from a "God and King" ideology which swept the army in the Seven Years War. Though Frederick was unable to hide his foibles from those who knew him intimately, he was able to be the familial but stern Landesvater his men

\footnotetext{
${ }^{3}$ Tim Blanning, Frederick the Great: King of Prussia, (Random House: New York, 2016) 296.
} 
expected. These men, rather than mocking and despising Frederick, retained their love and respect for him during the hard years of war. Frederick cultivated a rapport with his soldiers that presented him as a comforting and familiar, yet distant and powerful figure. This combination allowed his soldiers to retain their high opinion of the king and prevented mutiny and scrutiny from the lower ranks during the Seven Years War.

In addition to connecting with recent historiography regarding Frederick and his army, this chapter converses with what might be called a scholarly revolution regarding the motivation of private soldiers in the eighteenth century. ${ }^{4}$ For much of the twentieth century, historians believed that the Prussian army, and eighteenth-century armies in general, were "a slow and unwieldy mass of disgruntled and terrorized soldiers led by untrained and unimaginative officers." ${ }^{5}$ New scholarship, such as the work of Jörg Muth, Peter H. Wilson, Sascha Möbius, Marcus von Salisch, and Ilya Berkovich, has demonstrated that "honor, esprit de corps, professionalism, Protestantism, and patriotism," in addition to draconian discipline, motivated the Prussian army in the ancien regime. ${ }^{6}$ By studying more precisely the specific roles played by

\footnotetext{
${ }^{4}$ Glenn A. Steppler, "The Common Soldier in the Reign of George III, 1760-1793" (PhD diss., Oxford, 1984).; Peter H. Wilson, "Prusso-German Social MIlitarization Reconsidered," in Preussen, Deutschland, Und Europe 17012001, ed. Jürgen Luh, Vincent Czech, and Bert Becker (Groningen: Institute for North and East European Studies, 2003).; Jörg Muth, Flucht Aus Dem Militärischen Alltag: Ursachen Und Individuelle Ausprägung Der Desertion in Der Armee Friedrichs Des Grossen: Mit Besonderer Berücksichtigung Der Infanterie-Regimenter Der Potsdamer Garnison(Freiburg Im Breisgau: Rombach Verl., 2003).; Alan L. Forrest, Napoleon's Men: The Soldiers of the Revolution and Empire (London: Hambledon Continuum, 2006).; Marcus Von Salisch, Treue Deserteure: Das Kursächsische Militär Und Der Siebenjährige Krieg (München: R. Oldenbourg, 2009).; Sascha Möbius, Mehr Angst Vor Dem Offizier Als Vor Dem Feind?: Eine Mentalitätsgeschichtliche Studie Zur Preußischen Taktik Im Siebenjährigen Krieg (Saarbrücken: AV Akademikerverl., 2012).; Don N. Hagist, British Soldiers, American War: Voices of the American Revolution (Yardley: Westholme, 2014).; Yuval Harari, Ultimate Experience: Battlefield Revelations and the Making of Modern War Culture, 1450-2000(London: Palgrave Macmillan, 2014).; Ilya Berkovich, Motivation in War: The Experience of Common Soldiers in Old-regime Europe (Cambridge, United Kingdom: Cambridge University Press, 2017).

${ }^{5}$ Andrew R. Wilson, "Masters of War: History's Great Strategic Thinkers" (lecture, Naval War College, Newport, Rhode Island).

${ }^{6}$ Blanning, Frederick the Great: King of Prussia, 292.
} 
God and the royal figure in Prussian soldierly patriotism, this chapter contributes to a wider scholarly reevaluation of eighteenth-century soldiers.

Despite the rancor which existed between Frederick and some of his officers, the "Great" king was able to retain the loyalty of his common soldiers, whether native Prussian cantonists or foreign volunteers and conscripts. Via a mix of religious solidarity and an established ritual of military paternalism, Frederick personally motivated many of his men, but remained distant enough from them to avoid the familiarity and disdain which marred relations with the Prussian officer corps. As Adam Storring has suggested, other Prussian officers, rather than the genius of Frederick, may be responsible for the victories that the army enjoyed in the Seven Years War. ${ }^{7}$ The officer corps seemed well aware of that fact. As Katrin and Sascha Möbius have demonstrated, common soldiers could also criticize the military decisions of the king, particularly when they were called on to attack difficult enemy positions. ${ }^{8}$ Despite this, the common soldiers of the army continued to invoke the motto of "God and the King," believing these two sources of authority and protection would see them through any dangers.

\section{RELIGION IN THE EIGHTEENTH-CENTURY PRUSSIAN ARMY}

In Prussia, displays of religious feeling among common soldiers were communal and army wide. Sascha and Katrin Möbius have examined religion in the Prussian Army extensively, as a combat motivation, exploring the use of prayer and calls for prayer and intercession, and a belief in the providence of God. ${ }^{9}$ This chapter confirms and enhances their arguments, and using

\footnotetext{
${ }^{7}$ Adam Storring, "Frederick the Great and the Meanings of War, 1730-1755” (Ph.D Diss. University of Oxford, 2018)

${ }^{8}$ Katrin and Sascha Möbius, Prussian Army Soldiers and the Seven Years War: The Psychology of Honour, (London: Bloomsburg Academic, 2020) 147.

${ }^{9}$ Sascha Möbius, Mehr Angst vor dem Offizier als vor dem Feind, 107-111, Katrin and Sascha Möbius, Prussian Army Soldiers and the Seven Years War: The Psychology of Honour, 90-92, 135-137.
} 
letters as a source base, explores the attributes that Prussian soldiers developed in their view of God, not just in combat, but as they experienced life in the Prussian Army and beyond.

As a result of the agreements reached between King Frederick William I and the Halle Pietist movement in the 1710s, Pietists provided all of the chaplains, or Feldprediger, for the Prussian military. Although common soldiers initially viewed these chaplains with suspicion, by the 1740s the Pietists had made serious inroads into the Prussian army. During battle, Feldprediger often stood alongside their soldiers, leading them in the singing of hymns, and attempting to inspire them. Pastor Joachim Friedrich Seegebarth rallied the fleeing regiment of Erbprinz Leopold at the Battle of Chotusitz, he recalled,

Our regiment was falling back and became partly mixed with the enemy cavalry and grenadiers. I came up, and called out the soldiers and officers in moving and serious terms that they must stand fast and rally. A number of them were willing enough and at once answered with a loud, “yes!' ... After my intervention the bullets flew about my head like a swarm of buzzing gnats, but thanks be to God my coat was not even touched. ${ }^{10}$

In addition to this battlefield role, chaplains recorded notes about individual soldiers in their record books, including soldiers promising to live more holy lives. ${ }^{11}$ The chaplains played an active role in soldiers' lives; they prayed with soldiers in the morning and evening, and served as the teachers for soldiers' children during the working day. ${ }^{12}$

\footnotetext{
${ }^{10}$ Georg Heinrich Von Berenhorst and Eduard Von Bülow, Aus Dem Nachlasse Von Georg Heinrich Von Berenhorst (Dessau: K. Aue, 1845), 99-100.

${ }^{11}$ Carl Hinrichs, Preussentum und Pietismus: Der Pietismus in Brandenburg-Preussen als Religiössozial Reformbewegung, (Göttingen: Vandenhoeck \& Ruprecht, 1971) 164.

${ }^{12}$ For more on the Pietist Chaplaincy, see, Benjamin Marschke, Absolutely Pietist: Patronage, Factionalism, and State-Building in the Early Eighteenth-Century Prussian Army Chaplaincy (Leipzig: Max Niemeyer Verlag, 2005).
} 
By the 1750s, Prussian common soldiers frequently employed religious language in their writings. Sergeant G. S. Liebler, a Pietist from the Halle region, who served alongside his equally religious son, J. S. Liebler, noted soldiers' devoted attendance at daily prayer meetings:

I rejoice in God whenever I attend our daily prayer meetings, which are always held at $10 \mathrm{a}$.m. by the whole army. I even see devotion and awe on the part of our superiors, though not in all, and this spiritual leadership awakens some of the soldiers. Lord Jesus, awaken them all, that all of us may become spiritual champions for your honor and for the benefit of the Christian Church. ${ }^{13}$

Likewise, some Prussian soldiers had adopted the Lutheran language which framed human experience as a struggle between two kingdoms: the Kingdom of God, and the King of this world. Contemporaries wrote regarding the Children of God (Kinder Gottes) and Children of the World (Weltkinder). ${ }^{14}$ At least some Prussian soldiers framed their existence along similar terms, but employed the idea of Satan and the World, or Worldly, (Satan die Welt, Weltlich) as opposed to Weltkinder. ${ }^{15}$ Devout soldiers viewed themselves as the Kinder Gottes, and admonished their worldly comrades as Weltkinder.

After some battles, soldiers might set up small altars built of stones as a sign of their religious devotion and thanksgiving for their preservation. ${ }^{16}$ Prussian soldiers frequently sang hymns both before and after battle. The most famous instance of this was after the Battle of Leuthen in 1757, which has passed into the realm of mythology and nationalistic memory as a result of early twentieth-century film. A young officer with the Prussian army, Friedrich August von Retzow, described the scene:

\footnotetext{
${ }^{13}$ Curt Jany, Urkundliche Beiträge Und Forschungen Zur Geschichte Des Preussischen Heeres. Berlin: E.S. Mittler, 1901, 34 .

${ }^{14}$ Ibid, 55,42 .

${ }^{15}$ Ibid, 42 .

${ }^{16}$ Christian David Kessler, et al. Neues Journal für Prediger. (Halle: Karl August Kummel, 1807), 272.
} 
The march was completely silent, as soldiers reflected on the events of the bloody day... but suddenly a grenadier began to sing out the familiar song, "Now Thank we all our God." As if stirred from a deep sleep, they thanked God for the gift of preservation, and more than 25,000 voices sang out unanimously. ${ }^{17}$

The communal singing of hymns was more than simply an expression of gratitude.

Before battle, the Prussian army would move to attack accompanied by regimental music, often religious songs and hymns. This particular pre-battle ritual could have an inspiring effect on Prussian soldiers as well as overawing enemy forces. A captured Prussian Pastor, Christian Täge, observed the movements of Prussian army directly before the Battle of Zorndorf. Täge wrote: "Never shall I forget the silent majestic approach of the Prussian army... for a time their woodwind was inaudible, but as the Prussians approached we could hear the oboes playing the well-known hymn, Ich bin ja, Herr, in deiner Macht!" (I am, Lord, in thy Power). ${ }^{18}$ Ilya Berkovich has used a longer passage from this source to discuss the coping mechanisms available to eighteenth-century soldiers. Berkovich suggests that two of the largest components were "prayer [and] fatalism," but it would be wrong to reduce our understanding of the significance of religion among soldiers to fatalism and combat motivation. ${ }^{19}$ Religion was an ever-present factor in the lives of many Prussian soldiers. Christian practices dictated their daily routine, informed their worldview and belief system, was present in their letters home to their families, and fundamentally shaped their world. For these men, the literal presence of God was a matter of fact and not simply faith.

\footnotetext{
${ }^{17}$ Friedrich A. von Retzow, Charakteristik der Wichtigsten Ereignisse des Siebenjährigen Krieges, in Rücksicht auf Ursachen und Wirkungen (Berlin: Himburg, 1802), 252.

${ }^{18}$ Christian Täge, "K Istorri Semiletnei Voiny, Zapiski Pastora Tege,” Russkii Akchiv, (1864), 2:295-6.

${ }^{19}$ Berkovich, Ilya. Motivation in War: the Experience of Common Soldiers in Old-Regime Europe. Cambridge, United Kingdom: Cambridge University Press, 2017, 226-227.
} 


\section{PRUSSIAN SOLDIERS' VIEW OF GOD}

In order to better understand the "God and the King" ideology which swept the Prussian Army during the Seven Years War, it may be helpful first to understand what God meant to eighteenth-century Prussian soldiers. How did Prussian soldiers develop their view of God, and what attributes of God did they emphasize? Christianity permeated the living world of Prussian peasants in the eighteenth century. It did so primarily in three ways. First, local religious leaders at the village level gave direct instruction on how to live as men and women of faith. ${ }^{20}$ Second, literate peasants instructed themselves on the tenets of the Christianity via the reading of scripture in their vernacular language. ${ }^{21}$ Third, ideas concerning faith were culturally circulated in sayings, poems, and songs by both religious figures and the peasants themselves. ${ }^{22}$ These three methods of consuming and internalizing religious ideas provided Prussian soldiers with the theology they carried into the War of Austrian Succession and the Seven Years War. By examining the writing of Prussian soldiers directly, rather than utilizing the sermons of Feldprediger, historians can observe that all three of these methods of religious practice and discourse were present in the Prussian Army. ${ }^{23}$

\footnotetext{
${ }^{20}$ For peasants' desire to have more religious instruction in their local communities, see William G. Hagen, Ordinary Prussians: Brandenburg Junkers and Villagers, 1500-1840, (Cambridge: Cambridge University Press, 2002) 443.

${ }^{21}$ For the presence of small bibles in peasant homes, see: Hagen, Ordinary Prussians, 224.

${ }^{22}$ For the importance of hymns in village life, see: Hagen, Ordinary Prussians, 451.

${ }^{23}$ The historiography of early modern religious life in Prussia is large. Important works include: Otto Hintze, "Die Epochen Des Evangelischen Kirchenregiments in Preussen," in Regierung Und Verwaltung: Gesammelte Abhandlungen Zur Staats-, Rechts- Und Sozialgeschichte Preussens (Göttingen: Vandenhoeck und Ruprecht, 1967), pp. 56-96.Carl Hinrichs, Preussentum Und Pietismus: Der Pietismus in Brandenburg-Preussen Als religiös-Soziale Reformbewegung (Göttingen, 1971). Hellmuth Heyden, "Die Kirchenpolitik in Pommern von der Teilung des Landes 1648 bis zur Mitte des 19. Jahrhunderts.," Baltische Studien 57 (1971).; Otto Hintze, The Historical Essays of Otto Hintze (New York: Oxford University Press, 1975).; Eric Gritsch, "Luther and the State: Post-Reformation Ramifications," in Luther and the Modern State in Germany, ed. James Tracey, (Kirksville: Missouri, 1986).;
} 
Direct instruction by religious authority is relatively easy to demonstrate. The practice of attending religious services on Sunday was both relatively common across German Central Europe and mandatory for Prussian soldiers in the eighteenth century. The Prussian Army held prayer services for fifteen minutes every morning and evening, soldiers attended a longer service, in which the Feldprediger preached a sermon on Sundays, and every other week soldiers could receive communion. ${ }^{24}$ This communion was the ritualized consumption of blessed bread and wine that became, according to Lutheran theology, the real body and blood of Jesus Christ. Common soldiers described these gatherings, even during wartime. ${ }^{25}$ It is impossible to tell how seriously the vast majority of soldiers took this form of religious instruction, but at least according to Feldpregider Karl Daniel Küster, religious devotion increased in the Prussian Army as the Seven Years War continued. ${ }^{26}$ Prussian cantonists attended religious services when on leave in their villages, and were instructed to dress in their full uniforms on Sunday for service as a mark of respect. ${ }^{27}$ Direct religious instruction, then, played a large role in the development of religious ideas and faith among Prussian soldiers. They experienced religious instruction on a daily basis while in the military, and, if they attended religious services in their local community, on a weekly basis at home. Some Prussian soldiers were so connected to their civilian religious

Richard L. Gawthrop, Pietism and the Making of Eighteenth-Century Prussia (Cambridge: Cambridge University Press, 1993).

${ }^{24}$ Christopher Duffy, The Army of Frederick the Great, $2^{\text {nd }}$ Edition (Chicago: Emperor's Press, 1994) 207.

${ }^{25}$ Curt Jany, Urkundliche Beiträge Und Forschungen Zur Geschichte Des Preussischen Heeres. Berlin: E.S. Mittler, 1901, 34.

${ }^{26}$ Karl Daniel Küster, Des Preussischen Staatsfeldpredigers Küster, Bruchstück Seines Campagnelebens Im Siebenjährigen Kriege... Nebst Einem Vorbericht Des Königl. Herrn Oberkonsistorialraths Sack. Zweyte ... Stark Vermehrte Ausgabe (Berlin, 1791), 84.

${ }^{27}$ Ulrich Bräker, Lebensgeschichte Und Natürliche Abentheuer Eines Armen Mannes Von Tockenburg, (Zurich: Hans Heinrich Füssli, 1789)165-166. Soldiers also attended wedding feasts in full uniform, as they are recorded as carrying swords on these occasions. See William W. Hagen, Ordinary Prussians, 472. 
authorities that they listed them among their friends and kinship networks in their letters. ${ }^{28}$ Grenadier Johann Herman Dresel listed his local preacher, Pastor Löbecken, directly after his family and before his friends and acquaintances. ${ }^{29}$ For all the obvious importance of direct instruction by religious authorities, its mere existence does not indicate that Prussian soldiers were more than passive listeners in their religious lives. For evidence of active engagement, we must move to the second way by which Prussians received religious instruction: reading the scriptures and sharing passages of scripture with their families.

The letters of Prussian soldiers demonstrate that these men were avid readers of scripture. The fact that Prussian soldiers actively read scripture and imparted it to memory provides historians with evidence that these men took on an active role in religious observance. Prussian soldiers both listened to religious instruction and sought out an understanding of the Christian scriptures for themselves. In their letters, Prussian soldiers quoted, paraphrased, and referenced scripture. Moreover, these references were not merely related to the central role of God in providing them with protection and salvation, but rather to relatively obscure figures and passages of scripture which demonstrate a very high level of biblical literacy among Prussian soldiers. In addition to the commonly invoked God the Father, Jesus Christ, and Holy Spirit, Prussian soldiers frequently quoted and mentioned lesser-known figures present in scripture. In a letter describing the Battle of Palzig on July 23, 1759, Prussian soldier Johann Jacob Dominicus referenced Jewish King Hezekiah's song of Thanksgiving from the Book of Isaiah in the Christian Old Testament. Dominicus stated that in the heat of battle, "I had the same thoughts as

\footnotetext{
${ }^{28}$ Georg Liebe, Preussische Soldatenbrife aus dem Gebiet der Provinz Sachsen im 18. Jahrhundert, 29-30; Rolf Dieter Kohl, "Ein Brief des Wiblingwerder Bauernshones Johann Hermann Dresel aus dem Siebenjährigen Krieg, Die Märker, 84.

${ }^{29}$ Rolf Dieter Kohl, "Ein Brief des Wiblingwerder Bauernsohnes Johann Hermann Dresel aus dem Siebenjährigen Krieg, Die Märker, Vol. 28, No. 3(1979) 83-84.
} 
King Hezekiah: 'The Lord has cut off like a weaver my life, from day to night wilt he make an end of me. ${ }^{\prime 30}$ This is a paraphrased quotation of Isaiah $38: 12 .{ }^{31}$ Sergeant Liebler mentioned the warrior judge Gideon from the Old Testament Book of Judges. ${ }^{32}$ After the Battle of Lobositz, Barthel Linck, a soldier in the Alt-Anhaltische Regiment, wrote to his wife that the war and her letters had brought "the wars of the Old Testament, especially the example of Joshua and Gideon to mind. ${ }^{33}$ In a letter home to his wife, Sergeant Liebler demonstrated an extreme level of biblical literacy, quoting or paraphrasing from the books of Deuteronomy, Psalms, Lamentations, and $2^{\text {nd }}$ Corinthians. ${ }^{34}$ Johann Hermann Dresel also quoted the Book of 2 Corinthians at length in a letter home to his father on May 15, 1759. ${ }^{35}$ Soldier Frantz Rie $\beta$ was able to identify the Thanksgiving passage of the Hülsen Regiment after the Battle of Lobositz as Romans 8:36-7, and paraphrased this passage in a letter to his wife. ${ }^{36}$ All of this points to a high level of biblical literacy among soldiers. Not only did Prussian common soldiers receive sanctioned instruction regarding religion, they read scripture frequently in order to internalize the word of God and pass it on to their loved ones in correspondence.

In addition to direct instruction and reading of the Holy Scriptures, Prussian soldiers also existed in a world which contained a great deal of religious symbolism. Their entire culture, from letter greetings to children's sayings, to the way that they approached death, was permeated with religious overtones. In their letters, the most obvious example of this are the initial greetings

\footnotetext{
${ }^{30}$ Dominicus, eds. Kerler, Aus dem Siebenjährigen Krieg. Tagebuch des preußischen Musketiers Dominicus, (Osnabrück: Biblio Beck'sche Verlag, 1972), 63.

${ }^{31}$ For a more thorough description, see Möbius, Prussian Army Soldiers, 179.

${ }^{32}$ Jany, Urkundliche Beiträge, 34.

${ }^{33}$ Ibid, 15.

${ }^{34}$ Ibid, 44-49.

${ }^{35}$ Kohl, "Ein Brief des Wiblingwerder Bauernshones Johann Hermann Dresel aus dem Siebenjährigen Krieg, Die Märker, 84.

${ }^{36}$ Curt Jany, Urkundliche Beiträge, 15.; This was also noted by Sascha and Katrin Möbius, Prussian Army Soldiers, 65.
} 
used. These greetings take different forms, from simple sayings to theological references. The most common include "Greetings in Jesus," "[Go] with God," "Greetings in Jesus and the Loving God be with us," "Greetings in Jesus and God with us all," "Greetings in Jesus and [may] God be with you." ${ }^{37}$ Other greetings included "God is with us" and "To God Alone be the Glory." 38 The last phrase, included in Latin, Soli Deo Gloria, is a reference to the idea that God, not soldiers, were responsible for military success on the battlefield. Though this rather complex idea is an isolated example, the ubiquitous nature of common and basic religious greetings in Prussian soldiers' letters indicates that religious language was the expected norm in communications between literate family members.

In addition to these common religious greetings, historians can observe a number of other examples of the prevalent nature of Christian symbolism in the everyday world of the Prussian Army. Barthel Linck noted that when his section of the line began to advance at the Battle of Lobositz, his mind was drawn to a common song, sung in the morning as the day was beginning: "Holy Trinity, Highly Praised Triune God: God the Father, God the Son, God the Holy Spirit, lend us assistance today." 39 Linck noted that as he "surrendered to the will of God," this song, rather than scripture or a sermon, was what came to his mind. Likewise, J.S. Liebler requested that his wife teach his child a saying reminiscent of Psalm 46:1: "God is our confidence and strength, a help in time of great troubles, when they strike, we are not afraid." ${ }^{40}$ Katrin and Sascha Möbius have correctly noted that soldiers and peasants used religious sentiments to cope

\footnotetext{
${ }^{37}$ Christian F. Zander, Fundstücke - Dokumente Und Briefe Einer Preußischen Bauernfamilie: (1747 1953) (Hamburg: Kovacì, 2015).; Hans Bleckwenn, Preussische Soldatenbriefe (Osnabrück: Biblio Verlag, 1982) 21-82.

${ }^{38}$ Jany, Urkundliche Beiträge, 11,24.

${ }^{39}$ Ibid, 12.

${ }^{40}$ Ibid, 20.
} 
psychologically with the "traumatizing and depressing experiences of war." ${ }^{\text {"41 }}$ Religious belief followed soldiers from their village communities of origin and was something that these soldiers took seriously and literally. Although early modern religious scholars have noted the firm and real presence of religion in peasant daily life, military historians have often focused on religion purely as a combat motivation. Religion did not simply cross these soldiers' minds when they entered combat; it was a fixed part of their worldview.

Historians can also observe the cultural impact of Christianity in the common wartime experience of death. Musketeer Johann Christian Riemann served in the "Jung Stutterheim" Regiment and had the uniquely painful experience of witnessing the death of his brother, Benjamin, in the last months of the Seven Years War. In the pain of this loss, Johann wrote primarily to his sister, who may have been staying with his cousin, Heinrich Röbern. Riemann repeatedly references the fact that he will see his brother again, and more importantly, that Riemann, his sister, and his brother Benjamin would all be reunited after death. Riemann particularly notes the way in which his brother was interred; that he obtained a coffin and was "buried decently" seems to have meant a great deal for the grieving brother. ${ }^{42}$ Through a literal belief in God's power to reunite the dead, Johann Riemann made sense of the tragic loss of his brother.

If Prussian soldiers obtained a religious worldview via direct instruction by religious authorities, self-instruction via Holy Scriptures, and experienced cultural references to Christianity on a regular basis, how did they formulate a view of God? Most Prussian soldiers emphasized two aspects of God in their writings: God's love and his power. These two aspects of

\footnotetext{
${ }^{41}$ Möbius, Prussian Army Soldiers, 136.

${ }^{42}$ Georg Liebe, Preussische Soldatenbrife aus dem Gebiet der Provinz Sachsen im 18. Jahrhundert, 32-33.See also, Möbius, Prussian Army Soldiers, 74.
} 
God fit well together in the worldview of Prussian soldiers. A loving God cared for them personally and reflected the love that they felt for their families and their homes. A powerful God could provide personal protection against sickness and the horrors of the battlefield, and also ensure the overall victory of the Prussian Army against the many enemies it faced. Likewise, a loving and protecting God would understand soldiers' fears for their families and take those loved ones into his protective care during their absence. Barthel Linck, wrote briefly to his wife after the Battle of Lobositz. His words sum up the Prussian soldier's view of God: “The merciful, benevolent, faithful, and loving God has fulfilled this powerful promise of divine protection for our army, showering us with undeserved grace and worth today, on the $1^{\text {st }}$ of October, out of his fatherly divine love." ${ }^{43}$

Prussian soldiers emphasized God's love for them personally as individual soldiers, as well as protecting their king and cause. Johann Hermann Dresel wrote of the divinely "dear" or loving (Liebe) God's ability to grant peace that would end the war as well as the knowledge that such an affectionate God possessed. ${ }^{44}$ Barthel Linck noted that "God wants to take us into Grace," and that though he could not write all the details in his letter, he would tell his wife about everything "when the loving God brings me back to you." ${ }^{, 45}$ Herr Kistenmacher, the secretary of August Wilhelm, Duke of Braunschweig-Bevern, noted, "The loving God has protected the Duke, though he stood in the strongest fire." 46 Frantz Rei $\beta$ asked his wife to "join your prayers with mine, that the loving God will protect me further."47 Many Prussian soldiers

\footnotetext{
${ }^{43}$ Jany, Urkundliche Beiträge, 12.

${ }^{44}$ Kohl, "Ein Brief des Wiblingwerder Bauernshones Johann Hermann Dresel, 82-3.

${ }^{45}$ Jany, Urkundliche Beiträge, 15.

${ }^{46}$ Ibid, 10.

${ }^{47}$ Ibid, 32 .
} 
referenced God's love in their writing, and united the idea of his love for them with the concept of divine protection.

In the worldview of Prussian soldiers, God was an all-powerful being who took a direct interest, not only in the outcome of particular battles, but the survival of individual soldiers. In essence, God was the ultimate patron who could be called upon to give their army victory, provide them with protection, and safeguard their families during their absence. Prussian soldiers frequently noted that without God's assistance they would have been defeated. Kaspar Kalberlah asked his family to pray "God does not allow this enemy to become too mighty and conquer us, otherwise we will all fare badly. ${ }^{, 48}$ Frantz Rei $\beta$ noted that the success at the Battle of Lobositz would have been impossible without divine protection: "But alone, our small group would have been insignificant against [the Austrians], if God had not been on our side we all would have been struck down, but thank God, it is finished. ${ }^{, 49}$ In the same vein, soldier J. S. Liebler instructed his family to "praise the goodness of the Lord, for He has done great things for us." Using the exact same phrase in a letter over six months later, his father Sergeant Liebler noted before the Battle of Prague, "The Lord has done great things for us, if the Lord were not with us, our enemies would have devoured us. ${ }^{, 51}$ Sergeant Müller wrote to his wife after the Battle of Prague, "I am still in good health, God be praised, and believe that our actions will continue to go well, with divine assistance." ${ }^{, 52}$ Müller linked two ideas: God's care for the army as a whole and care for his health personally. Even as Prussian soldiers trusted that God would ensure

\footnotetext{
${ }^{48}$ Liebe, Preussische Soldatenbriefe, 29-30.

${ }^{49}$ Jany, Urkundliche Beiträge 31.

${ }^{50}$ Ibid, 16.

${ }^{51}$ Ibid, 40.

${ }^{52}$ Ibid, 58.
} 
victory over the enemies of their Prince and state, they entrusted their personal well-being to Him.

Prussian soldiers believed that God directed not just the flow of battles as a whole, but the individual bullets which could harm them. Katrin and Sascha Möbius have noted the way in which this psychologically boosted soldiers in combat, and have demonstrated that religious thoughts of personal protection helped keep soldiers from flight. ${ }^{53}$ Soldiers linked survival in combat with divine protection and seem to have especially cherished close calls with death as evidence that God had miraculously preserved them. Johann Jacob Dominicus noted in a letter to his brother that God had taken special care of him at the Battle of Paltzig, and recorded this in some detail:

I have four signs that show how miraculously the Lord saved me: one bullet went through the tip of my hat, one through the turnback, one went into the butt of my musket and a part of the cover of my cartridge pouch was shot off. While I was standing and loading, a bullet flew just over my hand and bent my ramrod like a fiddlestick. Next to me on my left, the legs of three men were evenly shot off at the same height - there is no doubt that this had been done with chain-shot. The man to my right was wounded and the one next to him killed... But I saw that my time had not yet come, and was so full of sorrow that I could not give thanks to God nor sing a song of praise. Help me with that, my friends! To thank God that he protected me and ask him to further safeguard me due to his grace, because it has not come to an end, yet. Many of us defect, but I will not break my oath if God further grants health and life to me, I will remain faithful to God and the king and will bear the burden as long as God wants me to. I have often experienced many temptations and tribulations, but the Lord God has maintained my good thoughts and I will lead my life and actions in a way I can answer for to God and man. ${ }^{54}$

Dominicus' statements are nothing short of extraordinary, giving us a window into the visceral and psychologically demanding nature of eighteenth-century combat. Dominicus offers evidence of deadly combat and divine protection but could not bring himself to praise God for it as a result

\footnotetext{
${ }^{53}$ Möbius, Prussian Army Soldiers, 136.

${ }^{54}$ Dominicus, Aus dem Siebenjährigen Krieg, 62-63.; See Katrin and Sascha Möbius, Prussian Army Soldiers, 178181 , for a full translation of this letter.
} 
of the shock and horror of near death. Indeed, he requests assistance from his friends and promises to maintain his loyalty to both God and the king.

Far from being unique, Dominicus's horrific experiences are echoed in the writings of other Prussian soldiers from the era of the Seven Years War. Frantz Rei $\beta$ recalled the shocking experience of the first major battlefield encounter of the war at Lobositz:

So the battle began at six o'clock in the morning and dragged on amidst thundering and firing until four in the afternoon, and all the while I stood in such danger that I cannot thank God enough for my health. In the very first cannon shots [my friend] Krumpholtz took a cannon ball through his head and the half of it was blown away, he was standing just beside me, and Bode [was hit by Krumpholtz] brains and pieces of his skull and my musket was blown to pieces from my shoulder, [he] praise God, was uninjured. Now, dear wife, I cannot possibly describe what happened, for the shooting on both sides was so great, that no-one could hear a word of what anyone was saying, and we didn't see and hear just a thousand bullets, but many thousands. But as we got into the afternoon, the enemy took flight and God gave us the victory. And as we came forward into the field, we saw men lying, not just one, but 3 or 4 lying on top of each other, some dead with their heads gone, others short of both legs, or their arms missing, in short, it was a horrifying sight. Now, dear child, just think of how we must have felt, we who had been led meekly to the slaughterhouse without the faintest inkling of what was to come. ${ }^{55}$

In his same letter Rei $\beta$ paraphrased the regimental scripture reading which his regiment listened to after the battle. ${ }^{56}$ Like Dominicus, he notes the death of soldiers around him, in this case a man who was known to his wife and local community, Krumpholtz. Rei $\beta$ felt the horror of this loss keenly. Sergeant Liebler also recorded brushes with death as a sign of God's protecting power:

Now a battalion of grenadiers advanced, whereby General von Ingersleben commanded us to follow, and again we came under the hail of canister shot, and here I learned what it means to be under the shield of the Most High. A canister ball hit me on the sternum, and I certainly thought that my life was at an end, but the bullet did not pierce my flesh, I

\footnotetext{
${ }^{55}$ Jany, Urkundliche Beiträge, 30.

${ }^{56}$ See: Möbius, Prussian Army Soldiers, 183.
} 
staggered a few steps back but still stood under the rain of fire, until the grenadiers had to give way under the fire of this battery. ${ }^{57}$

For Liebler, Rei $\beta$, and Dominicus, facing heavy fire and having close brushes with death was a sign of divine protection. These men, though they saw scores of men cut down around them, believed that their lives had been marked for a special purpose by God. Their continued life, they argued, was a sign that God's protection was as tangible as the muskets they held and the bullets they fired.

These soldiers believed that God protected them and watched over their families while they were away. In their letters to family members left behind at home, again and again, Prussian soldiers closed with a benediction of divine protection for their families. Johann Herman Dresel closed his letter to his father and the rest of his family: "I commend you all to the protection of God the Most High, may he protect you from all evil and accidents, enemy invasions and all sorts of harm. God be our fellow traveler, now and forever." ${ }^{58}$ Because Prussian common soldiers held an extraordinary level of belief in God's protection for their own lives, they also believed that God would be able to defend and protect their families from all manner of troubles.

Such closing benedictions are present in most Prussian soldiers' letters. Sometimes they are as brief and simple as "May our dear God help us further on... by this we end and commit you to God." ${ }^{59}$ Kaspar Kalberlah listed most of his extended family, friends, and pastor, and then continued, "Give ... our regards... and commend them into God's protection." ${ }^{60}$ Barthel Linck ended his letter home, "I commend you and my dear children, as well as all my other good

\footnotetext{
57 Ibid, 47.

${ }^{58}$ Kohl, "Ein Brief des Wiblingwerder Bauernshones Johann Hermann,” 84.

${ }^{59}$ Liebe, Preussische Soldatenbrife, 26.

${ }^{60}$ Ibid, 30.
} 
friends... to the protection of the Triune God. ${ }^{, 61}$ Sergeant Liebler used almost the same exact phrasing in his later letter home on May 10, 1757: "In closing, loving wife, commend yourself, together with the children, to the protection of the Most High. ${ }^{.62}$ His son, J. S. Liebler, ended his letter to his own wife on a similar note: "May the Lord be with you, and hold fast to God's Word, that He will care for us, according to His Holy Will. Farewell!" ${ }^{63}$ Sergeant Liebler also used deeply Pietist and Moravian symbolism in his benedictions, referring to the wounds of Christ:

Holy Jesus, faithful Savior, I commend myself and my dear ones into your deep wounds, in those wounds we will always find our refuge. Come together again according to your holy will; so we will not cease to thank you forever and ever, as I will not stop proclaiming the mercy of God with my brethren. Oh do it all with me, praise the Savior, give thanks to the Lord, for he is mighty and of great power, Hallelujah! Amen. ${ }^{64}$

Sergeant Liebler's reference of the deep wounds of Christ references the theological concept of justification: faith in the cleansing power of the blood of Christ that washes sinners clean so they might gain entrance to heaven.

Soldiers realized that as they were away from home, there was little they could do to care for their loved ones. As a result, they entrusted their wellbeing to God. An anonymous soldier honestly wrote to his family that he wished to be reunited with them, if only for a moment: "My heart swells with joy, and it overflows with holy feelings when I think of the joys, songs of thanksgiving, joys and tearful songs of the true servants and children of God. I wish only to spend one hour with you again in our house. ${ }^{, 65}$ Soldiers attempted to trust the power of God to protect their army, themselves, and their families, but earnestly desired the end of the war and wished to be reunited with their loved ones.

\footnotetext{
${ }^{61}$ Curt Jany, Urkundliche Beiträge, 15.

${ }^{62}$ Ibid, 58

${ }^{63}$ Ibid, 20.

${ }^{64}$ Ibid, 48 .

${ }^{65}$ Ibid, 55 .
} 


\section{ROYAL FAMILIARITY: FREDERICK II AND HIS SOLDIERS}

Religious sentiments were crucial in Frederick's ability to cultivate loyalty among Prussian natives and foreign troops via mass-produced familiarity. Scripture, songs, and liturgical rituals helped to solidify his authority as king and military commander. General von Lossow observed, "The common soldier regarded the king as the representative of God, whom he must fear, honor, and love." ${ }^{66}$ It also appears that Frederick turned to religious language in the hour of his need. From 1760-1762, Frederick mentioned God ninety-three times in the text of his political correspondence. This is a far greater number of references to God in the text than for the rest of his reign up until that point. He also was a careful dissembler, referencing God to generals who had firm religious convictions, such as Leopold von Anhalt-Dessau and Hans Karl von Winterfeldt.

The letters of Prussian common soldiers, as discussed above, are full of religious language, and as a familial yet stern, harsh but caring, figure, Frederick worked his way into the cosmology of his men. Sascha Möbius has asserted that "God and the King" was the unofficial watchword of the Prussian Army, and it seems that linking divine protection with royal authority turned into something of an ideology during the Seven Years War. ${ }^{67}$ Feldprediger and author Karl Daniel Küster formulated this ideology more fully, in a sermon to his troops in 1758 , arguing that it had three parts: "1) God Lives. 2) The King Lives - 3) I will be true to God and

\footnotetext{
${ }^{66}$ Ludwig von Lossow, Denkwürdigkeiten Zur Charakteristik Der Preussischen Armee Unter Dem Grossen König Friedrich Dem Zweiten (Glogau: Carl Heymann, 1826), 3.

${ }^{67}$ Möbius, Leben in der Stadt, 92.
} 
the King until death." ${ }^{68}$ As a Feldprediger, Küster had a bias towards ascribing religious motivation to his men, but it is clear that this phrase was internalized by Prussian soldiers.

This ideology of "God and the king," summarized by Küster, can be seen in the writings of Prussian common soldiers. Prussian Musketeer Johann Riemann indicated that this sentiment was alive and well in some of the darker days of the Seven Years War. In the summer of 1762, after the death of his brother and fellow soldier Benjamin, Riemann wrote:

In such mortal danger, I have long survived, I will last the year if it pleases God, in such hunger as makes life miserable, none of us have heard or experienced it before. We ask God daily to have mercy on us and end the misery of life. We want to trust in God, who has helped us through many a sad time. As our enemies all circle: They are ours. God will assist the Prussian Army, and not forget his promises. God and Frederick still live. ${ }^{69}$

"God and the king" was indeed the watchword of the Prussian Army. After the defeat at Paltzig in July 1759, Johann Jacob Dominicus wrote home to his brother, "I will remain faithful to God and the King and bear this burden as long as God wants me to." ${ }^{, 70}$ An Anhaltiner in the Prussian army, Private Hoppe, recalled his sentiments for God and Frederick during the Zorndorf campaign of 1758. Speaking of the experiences of Anhaltiners, Hoppe wrote, "We foreigners did not grumble at these heavy tasks, because we knew quite well that we could not serve anywhere better than under the King, who saw the hardships of the common man and shared them... I never would have lasted so long without my faith in God and the King." ${ }^{71}$ With a loving and powerful God on their side, and a king who promised to care for them and listened to their complaints,

\footnotetext{
${ }^{68}$ Küster, Bruchstucke, 74. See also: Ernst von Barsewisch, Meine Kriegs-Erlebnisse während des Siebenjährigen Krieges, 1757-1763, (Berlin: Warnsdorff, 1863) 23.

${ }^{69}$ Liebe, Preussische Soldatenbriefe, 34-35.

${ }^{70}$ Dominicus, Aus dem Siebenjährigen Krieg, 63;

${ }^{71}$ Anonymous., Offizier-Lesebuch, Historisch-militärischen Inhalts, Mit Untermischten Interessanten Anekdoten, Von Einer Gesellschafts Militärischer Freunde (Berlin: C. Matzdorff's Buchhandlung, 1793), 180-2
} 
Prussian soldiers emphasized God and the king in explaining their loyalty, even as it became apparent that Prussia was not winning the wider war.

In the writings of most of his soldiers, Frederick remained a personable yet distant figure. A perfect illustration of this is provided by Christian Friedrich Zander, describing the aftermath of the Battle of Zorndorf in 1758. The men of Zander's regiment saw the king riding behind them, and he shouted,

Good morning, lads, are you still pretty healthy? Yes, the lads answered, but you should have taken us along to the Russians. He answered: You do not have to be around everywhere. Be patient. You shall soon make money with the Austrians. There you shall get good Kremnitz Ducats ${ }^{72}$ as a booty. They are better than rubles." 73

This friendly interaction between Frederick and his men was typical in the Seven Years War, and can be observed in a number of sources from common soldiers, including letters and diaries written during the war, officer's magazines published after the conflict ended, and interviews with old veterans in the 1820 s. $^{74}$

This type of story became a sort of ritual or exchange, almost on the level of a liturgical experience for Prussian common soldiers. The exchange usually began with the king offering a greeting and following up with a leading question, which the body of troops could collectively answer in the affirmative. The men usually followed their affirmative answer with a question regarding military life, or a tentative recommendation. The king ended the exchange with an appeal for patience, and a positive prediction of future events. Frederick certainly used this

\footnotetext{
72 "Kremnitz Dukaten "were gold coins produced in the Habsburg mint in Kremnitz (today Kremnica in Slovakia) and valued for their purity.

${ }^{73}$ This letter has not survived to the present, but a report of its contents have in: Zander, Fundstücke, 109-110.

${ }^{74}$ Dominicus, , Aus dem Siebenjährigen Krieg 59.; C. Hildebrandt, Anekdoten Und Charakterzüge Aus Dem Leben Friedrichs Des Grossen, (Halberstadt: Brüggemannn, 1829), 2:39.; Anonymous, Offizier-Lesebuch, Historischmilitärischen Inhalts, Mit Untermischten Interessanten Anekdoten, 185-186; Zander, Fundstücke , 109-110.
} 
method of addressing soldiers in the middle years of the Seven Years War, as many sources describe it between 1757 and 1759. This type of exchange in the Prussian service became so ubiquitous that its use was noted by Austrian governmental reports, which indicated that "the only way officers talk to soldiers is to say things like, 'cheer up lads, it will get better soon!' Words of this sort cost no money, but they encourage the soldiers in an extraordinary way, and establish affection for their officers." ${ }^{75}$ Like the King, Prussian officers drew on a similar paternalistic exchange. Frederick and his officers were able to use this type of interaction to create a sense that they were familiar with the challenges that soldiers faced in army life and interested in creating a moral economy of soldiering.

It is worth pausing for a moment to consider the significance of this ritual. The king could not be familiar with the tens of thousands of men in his army, on an individual level. As a result, this exchange provided the king with the ability to seem approachable to soldiers, as it could be reproduced across dozens of regiments. This mass-produced familiarity, which engendered excitement and loyalty among common soldiers, stands in stark contrast to the experiences of those who closely interacted with Frederick in the course of the war. The future military theorist, Georg Heinrich von Berenhorst, at this point a young officer with the King's entourage, recalled:

Frederick no longer commanded love, respect, or even fear among the nearest and most intimate members of his suite. I can say this because I saw it with my own eyes. When we rode behind him there was a mischievous young brigade-major of the cavalry, called Wodtke, who set out to amuse us by going into comic contortions behind his back, imitating the way he sat in the saddle, pointing at him and so on. Wodtke bestowed on Frederick the nickname 'Grave-Digger'. Later on

\footnotetext{
${ }^{75}$ Kriegsarchiv,Vienna, Kriegsakten 387, 'Verzeichness deren vornehmsten und wichtigsten Vortheile.'
} 
he abbreviated it to 'Digger', and this is what he called the great hero when we came together in private for jokes and malicious talk. ${ }^{76}$

It is impossible to know exactly how far these sentiments permeated the officer corps, but evidence suggests that by late 1761, they were widespread. The English ambassador, Mitchell, commented to Frederick that his officers "were like an army of Jacobites. ${ }^{17}$ By contrast, this mass-produced familiarity with enlisted men provided one way for Frederick to advance and promote his martial reputation with his soldiers.

Frederick appears to have been widely successful in cultivating sentiments of loyalty among native Prussian troops, and partially successful among non-Prussian foreigners in the army. The first way of measuring this is by examining loyalty in adversity among Prussian prisoners of war. By 1761, Austrian manpower shortages forced Maria Theresa to enlist Prussian prisoners of war against their will. These soldiers deserted the Austrian Army in large numbers, and many returned to Prussian service. A non-Prussian, Johann Christian Schimmel, is a perfect example of this type of non-Prussian loyalist. He gained the loyalty of his captors by pretending to convert to Catholicism and making preparations to marry a local girl. Upon being given a local suit of clothes, he immediately fled in the night, and over the next few weeks walked some 590 kilometers to his home village of Herzberg in Saxony. Upon returning to Herzberg, Schimmel briefly stayed with his relatives, and then went with his father to meet a Prussian recruiting party, where he was returned to his regiment. ${ }^{78}$ Schimmel's Prussian patriotism made him a liability to the Austrians, one that they recognized and tried to mitigate.

\footnotetext{
${ }^{76}$ Berenhorst and Bülow, Aus Dem Nachlasse Von Georg Heinrich Von Berenhorst, 181. Wodkte would eventually travel to the United States and die in the American War for Independence.

${ }^{77}$ Johann Georg Zimmermann, Ueber Friedrich Den Grossen (Wien: Ofen, 1788), 186.

${ }^{78}$ Johann Christian Schimmel, "Kurze Lebensbeschreibung des preussischen Veterans Johann Christian Schimmel," Zeitschrift für Kunst, Wissenschaft, und Geschichte des Krieges, Vol. 10, No.4-6 (1827) 190-192.
} 
Austrian government officials wrote that it would be best to separate Prussian prisoners of war from other deserters and prisoners, "whom they lead astray by their arguments, and the high opinion they impart concerning their king. ${ }^{179}$ In addition to native-born Prussians, German Protestant foreigners in the Prussian army also retained a deep sense of loyalty to Frederick. A Brunswicker, Johann Heinrich Bittner, spent at least eighteen months planning his escape from the Austrian Army. Bittner's scheme failed, and he was sentenced to ten years' labor on Austrian fortifications. ${ }^{80}$ Austrian army officers also noticed the bonds of loyalty between Frederick and his common soldiers. Jacob Cognazzio, a former Austrian Army officer, recalled that Prussian common soldiers knew that there was "no danger or burden of the war which was not shared by 'the Great Fritz' as [Prussian soldiers] called him in childlike respect and love." ${ }^{81}$ Soldiers combined their paternal affection for their monarch with their religious devotion, both in their letters, as has already been discussed, as well as in the songs they sang while on the march.

\section{GOD AND THE KING: RELIGIOUS AND MONARCHICAL IDEOLOGIES IN SONG}

Having examined the religious writings of Prussian soldiers, as well as the active role played by the king in their worldview, this chapter demonstrates the clear connection of these concepts through the medium of song. As noted at the beginning of this chapter, Prussian soldiers frequently sang in collective groups during the Seven Years War. The fused nature of religious and monarchical authority is extremely clear in these songs. Some were primarily religious or patriotic, but many of the songs fused these ideologies together in one medium for soldiers to express vocally. When employing these songs as sources, there is a debate regarding how frequently they were actually sung by soldiers. To some degree, it is impossible to answer

\footnotetext{
${ }^{79}$ Kriegsarchiv, Vienna: CA 1757 XI 2.

${ }^{80}$ Kriegsarchiv, Vienna, Kriegsakten 300, Sententia of court martial, 11 February, 1761.

${ }^{81}$ Jakob de Cogniazzo, Geständnisse Eines Oesterreichischen Veterans, (Breslau: Löwe, 1791), 2:27.
} 
this question. When the songs were set to the tune of a well-known older hymn, often a hymn written in the seventeenth century, it is perhaps more likely that they were sung by troops in the period, as there are many descriptions of soldiers singing hymns. Likewise, if the song does not contain nationalistic sentiments, which were rare among rural people in this era, it is again more likely that the songs were sung by soldiers in the field.

One of these songs, Man muß euch tapfer Preußen loben, (One must praise the brave Prussian) was set to the tune of the popular hymn Wer nur den lieben Gott läßt walten (Who only lets loving God rule). The hymn was written by Georg Neumark in 1657 and provided a tune that Prussian soldiers could already follow. Man muß euch tapfer Preußen loben praises Frederick, praises God, and employs paternal language, but the key verse unites these themes:

O Gott, du grosser Gnaden-Vater

Beschütze unser Stadt als Land

Sey du serner unser Berather,

Und la $\beta$ uns nicht aus deiner Hand,

Erhalte doch gnädiglich,

Unsern hochtheren Friederich.
O God you great Gracious Father,

Protect our town and land

Be ever more our advisor

And keep us in your hand.

Graciously receive

Our greatly esteemed Frederick. ${ }^{82}$

Two stanzas later, the song concludes:

Das Land wünschet viel Glück und Segen,

The land showers luck and blessings,

Dem Tapfern König Friederich: to the brave King Frederick,

Gott wolle ihn auf seinen Wegen With God leading him on his path

Erhalten allzeit gnädiglich, Receive graciously at all times, Und verleihen da $\beta$ dieses wahr, And let it be that this comes to pass,

${ }^{82}$ Dittfurth, Zehn Schöne neue Lieder aus dem Siebenjährigen Kriege, 6. 
Bleiben mög itzt und immerdar.

May it remain so forevermore. ${ }^{83}$

These verses do not rely on the personal piety of Frederick II, but rather insist on the keen relationship that God and the soldier-singers possess. These soldiers viewed their king as an object of divine interest, praying for his guidance and protection in their songs. God, Frederick, and the desires of the land became intertwined as soldiers intoned these refrains.

These sentiments are found in many of the songs of Prussian soldiers. The song Victory! The Tenth Battle, set to the tune of the hymn Was Hilfts Dir, Mensch, Dein Ungedult (Your impatience does not help you, People), proudly shouts, "Frederick has not perished, God has showered him with decorations." ${ }^{84}$ Many of the soldiers' songs surviving from the era of the Seven Years War celebrate the triumph of Frederick and their belief regarding God's role in that triumph. ${ }^{85}$ A song from 1758 sings out, "Life to King Frederick, a father to the soldiers, he will guide us further, God give luck and victory to our King Frederick!" ${ }^{86}$ Among these bombastic calls for victory, however, one song stands out for its relatively muted tone.

Ach Gott! Du wirts doch einmal machen

Daß wir das Danck und Friedens-fest

Erleben, und mit Freuden sagen:

Dem höchsten sey Lob, Ehrr und Preiß.

Bis hieher hat uns Gott geholfen,

Er wird uns auch noch weiter helffen.
Oh God, may you accomplish, That we might experience a festival of peace and with joy, say:

To the most High be praise, honor, and glory

God has helped us to this moment,

He will continue his help to us further.

\footnotetext{
${ }^{83}$ Ibid.

${ }^{84}$ Ibid, 15.

${ }^{85}$ Franz Wilhelm von Dittfurth, Die historischen Volkslieder des siebenjährigen Krieges, nebst geschichtlichen und sonstigen Erläuterungen, (Berlin: Franz Lipperheide, 1871) 13, 14, $20,26$.

${ }^{86}$ Ibid, 60.
} 
So weit hat uns nun Gott geholffen,

Lob, Ehr und Prei $\beta$ sey ihm gesagt

Auf ihn woll'n wir nun allzeit hoffen,

Er hat ja Tag und Nach die Wach:

Er ist der rechte Friedens-Fürst,

Nach dem die ganze Welt gedürstet.
God has assisted us this far,

Praise, Honor and Glory be to him

In Him let us place our hopes,

He keeps watch both day and night

$\mathrm{He}$ is the true Prince of Peace.

That the whole world desires. ${ }^{87}$

Although this song also references military life in other verses, the role of God as provider of peace and tranquility speaks clearer in this song than any other. For Prussian soldiers, God was not simply the avatar of victory; the Prince of Peace would see them safely reunited with their loved ones.

\section{CONCLUSION}

Prussian soldiers frequently mentioned that they hoped for peace and were much more concerned with returning to their families than devoted to an elusive final victory. Damian Friedmeyer, a soldier in Hülsen's Regiment, instructed his family in October 1756, "Do not tire of praying for us... but pray for an early peace." ${ }^{, 88}$ Barthel Linck asserted that "God wants a honorable peace." ${ }^{, 89}$ On November 18 1756, Adam Becker, a soldier in the Lingerfeld Grenadier Battalion, wrote to his family, saying, "Perhaps we will meet again soon, here the talk is strong for peace, may it happen with God's help. ${ }^{\prime 90}$ Sergeant Liebler closed his letter on April 10, 1757, "Oh Lord Jesus, bring us healthily together soon in peace." ${ }^{91}$ His May $10^{\text {th }}$ letter ends on a similar note: "I sincerely wish that we may all experience a complete peace." ${ }^{.92}$ It is important to

\footnotetext{
${ }^{87}$ Dittfurth, Zehn Schöne neue Lieder aus dem Siebenjährigen Kriege, 9-10

${ }^{88}$ Jany, Urkundliche Beiträge, 36.

${ }^{89}$ Ibid, 15.

${ }^{90}$ Ibid, 39.

${ }^{91}$ Ibid, 42.

${ }^{92}$ Ibid, 55.
} 
stress that Prussian soldiers' desire for peace was not entirely at odds with a belief in victory: note Barthel Linck's hopes for an "honorable peace."

Prussian soldiers sincerely hoped that their monarch would find success, and that God would grant them victory, but above all, they desired to be reunited with their families and loved ones. Most soldiers throughout time have hoped for victory rather than defeat, for reasons which range from survival, to a desire for glory or advancement, to a desire for material rewards. Although the Prussian Army in the Seven Years War was influenced by an ideology that emphasized subservience to religious and monarchical authority figures, Prussian soldiers remained primarily interested in a return to the peacetime norms, and being reunited with their village communities. Rather than turning to ideological fanaticism, Prussian soldiers embraced an ideology which fit squarely into their eighteenth-century worldview.

This chapter has analyzed the letters and songs of Prussian common soldiers during the Seven Years War, demonstrating that these soldiers firmly believed in a powerful and loving God who protected them and their families, while also embracing a familiarity with their monarch that was reinforced by religious beliefs. Soldiers developed and strengthened these beliefs by praying, singing, and reading scripture together, by writing to their local communities in language that clearly displayed their religious faith, and by showing concern for the wellbeing of their monarch as he passed through their lives. All of these elements can be detected in Johann Hermann Dresel's letter to his father: "We must trust in God, and beg his graciousness for our King and ourselves, that we will happily overcome the foe and achieve victory. And I hope that 
the loving God will soon grant us peace, so that we might be able to exchange these letters for speaking together in person, and I wish for that wholeheartedly.",93

In this letter, Dresel brings together a trust that God and the king will provide the longedfor peace, hope that God will protect both himself and his family, and a desire to return home to his family and loved ones. During this exploration of ideologies that animated Prussian common soldiers during the Seven Years War, the sources make clear how vital monarch, faith, family, home, and local communities were to this process. Prussian soldiers combined their firm belief in God with a hope that Frederick II would lead them to success over their enemies. As Prussian soldiers wrote home to their families, interacted with their monarch, and sang their hymns on the march, "God and the king" proved an ever-present watchword which sustained them in and out of combat. These elements of the daily lives of soldiers can be helpfully examined by focusing on the writings of men from the same regiment, who were often recruited from the same local community. The next chapter charts the course of a particular regiment in the Seven Years War. The von Itzenplitz or $13^{\text {th }}$ Infantry Regiment contains the highest proportion of surviving egodocuments from soldiers of any Prussian Regiment of this era, and therefore affords historians a unique opportunity for analysis.

${ }^{93}$ Kohl, “Ein Brief des Wiblingwerder Bauernsohnes Johann Hermann Dresel, 83-84. 


\section{"Ich habe drei unter dem Regiment": Local Ties and Regimental Service in the Regiment von Itzenplitz during the Seven Years War}

On May 6, 1787, Prinz Henri of Prussia, the younger brother of Frederick II, hosted a lunch for a specific group of veterans of the Seven Years War. The date was no random choice. Thirty years before, at the Battle of Prague, Prinz Henri desperately engaged the enemy, leading a flank attack across the Rocketnitzer Bach northeast of the city of Prague. Upon plunging into the stream, Henri had nearly been swept away, until musketeers of the Itzenplitz Regiment waded in after him and bore the Prince across the stream on their shoulders. After the battle, another of the royal brothers, August Wilhelm, recorded, "My brother [Henri] did wonders. The officers admire him, and the common soldiers swear by him. Heaven be praised that he was preserved, it is a miracle." ${ }^{1}$ Henri would go on to find military success in the Seven Years War, but did not forget the special services rendered by the Itzenplitz Regiment at Prague. Thirty years later, the Prince hosted the few surviving officers and men who had fought with him on that day in the Itzenplitz Regiment. Approximately eighty men, including around seventy old common soldiers, turned out to be honored by the elderly prince. $^{2}$

This chapter tells the story of four such common soldiers in the Itzenplitz Regiment whose writings have survived to the present: Ulrich Bräker, Johann Christian Schimmel, Christian Friedrich Zander, and Johann Diederich Zander. Historians commonly wrote unit histories in the nineteenth century, but this particular brand of historical writing has decreased in

\footnotetext{
${ }^{1}$ Ernst Berner and Gustav Berthold Volz, Aus Der Zeit Des Siebenjährigen Krieges: Tagebuchblätter Und Briefe Der Prinzessin Heinrich Und Des Königlichen Hauses (Berlin: Duncker, 1908), 297.

${ }^{2}$ Franz Ludwig von Haller, Militärischer Charakter Und Merkwürdige Kriegsthaten Friedrich Des Einzigen: Königs Von Preussen: Nebst Einem Anhang Über Einige Seiner Berühmtesten Feldherren Und Verschiedene Preussische Regimenter (Berlin: Bei Oemigke Dem Jüngern, 1796), 320.
} 
popularity since $1950 .{ }^{3}$ This chapter adopts this methodological approach as a result of a rare confluence of documents which make it possible to tell the story of a particular regiment of the Seven Years War from below, from the perspective of common soldiers in that regiment. Historians are hard at work uncovering the story of common soldiers in a variety of eighteenthcentury armies. That work is demonstrating that more writings from common soldiers exists than previously believed. Still, compared with the total number of soldiers who served in these armies, only a tiny fraction of soldiers left behind written documents. As a result of this, possessing writings from four individual soldiers from a particular regiment is a rarity, and worthy of note.

These sources consist of twenty letters from two soldiers in the regiment, an autobiographical memoir, and a statement given by an old soldier late in life. Drawing on recommendations from scholars of common soldiers in other eras, this chapter tells the story of these men from start to finish, from the time they enlisted in the regiment, to the moment of their desertion, death, or discharge. ${ }^{4}$ The fact that we have a relatively large sample of writing from common soldiers in the Itzenplitz Regiment makes writing regimental history from below possible for this eighteenth-century combat unit. Combining the methodology of narrative structure, Alltagsgeschichte, and regimental histories, this chapter explores the experiences of the soldiers in the Prussian army during the Seven Years War through the lens of the Itzenplitz Regiment.

\footnotetext{
${ }^{3}$ For a recent and excellent example of this type of study, see, Lucia Eileen Staiano-Daniels, The War People: The Daily Life of Common Soldiers, 1618-1654 (unpublished doctoral thesis, University of California Los Angeles, 2018).

${ }^{4}$ Jason Phillips, "Battling Stereotypes: A Taxonomy of Common Soldiers in Civil War History," History Compass 6, no. 6 (2008): 1417-1425
} 
The writings of common soldiers in this regiment largely connect with the themes already raised by this dissertation. As the Prussian soldiers of this unit fought their way through the Seven Years War, they employed family, village, and regional connections to thrive in the hardship of their military service. They experienced tense relationships with civilians and attempted to survive the world of battlefield violence. These men described and remembered war in different ways, based on their societal backgrounds and local identities. Although the "comrades" of the Itzenplitz Regiment were drawn together by war, they did not embrace a military identity which was hostile to civilians but remained in close contact with the civilian worlds they had left behind. As these soldiers experienced the horrors of war, they sought to use local identities in order to survive and be seen as honorable.

\section{SOURCE ANALYSIS}

Ulrich Bräker's Lebensgeschichte und Natürliche Abentheuer eines Armen Mannes von Tockenburg (The Life story and Adventures of a Poor Man from Tockenburg) provides this chapter with its best-known source. Bräker is likely the most famous Prussian common soldier and has been taken by generations of historians as the archetypal unwilling recruit and deserter from the Prussian Army. Born in the Swiss Confederation, Bräker travelled to Prussia, was forcibly enlisted in the Regiment von Itzenplitz, and after fighting in the first battle of the Seven Years War, made his escape, deserting from the army and returning home to his village of Wattil. Bräker published his life story, together with experiences in the Prussian Army in 1789. Jürgen Kloosterhuis has recently overturned the scholarly consensus on Bräker, demonstrating the way in which his experiences exemplify both the compulsory and emancipatory nature of Prussian military service for common soldiers. In Bräker's mental narrative, Kloosterhuis argues: 
Bräker understood the necessary heterogeneity of this military system and was therefore able to capture precisely the entire spectrum of the regimental culture associated with it, between fulfillment of duty, desertion and creation of identity. One must therefore be responsible to the "poor man" and read his texts carefully, not simply reducing him to the inevitable picture-book deserter, but also to respect his self-confident military mentality[. $]^{5}$

Demonstrating that Bräker used his military service in the creation of a self-confident identity, Kloosterhuis asserts that the Prussian Army provided its soldier-peasants with alternative mental structures which could be used in emancipatory ways. This chapter largely confirms Kloosterhuis's arguments, agreeing that Bräker was more than a simple unwilling recruit and deserter.

The second source from a common soldier in this regiment comes from Johann Christian Schimmel, who served as a musician in the Regiment von Itzenplitz during the Seven Years War. Schimmel's brief memoir was recorded and published in 1827, when he was ninety-seven years old. ${ }^{6}$ This brief memoir has all the hallmarks of an old "war story": it is dramatic, the protagonist has numerous close calls and escapes, and its telling clearly foreshadows the positive. Along the way Schimmel bumps into King Frederick and (as a result of transferring to the hussars) Marshall Blücher. ${ }^{7}$ As a result, it is vitally important that historians read Schimmel's rendition of his service with care. Schimmel interlaces bellicose and bombastic sentiments throughout his story, such as "Under three Kings have I worn the uniform of honor[.]"8 These statements should be treated with extreme care, as Schimmel lived long enough to formulate

\footnotetext{
${ }^{5}$ Jürgen Kloosterhuis, "Donner, Blitz und Bräker - der Soldatendienst des ,armen Mannes im Tockenburg' aus der Sicht des preußischen Militärsystems," In Schreibsucht-autobiografische Schriften des Pietisten Ulrich Bräker (1725-1798) (Göttingen: Vandenhoeck \& Ruprecht, 2004) 187.

${ }^{6}$ Johann Christian Schimmel, "Kurze Lebensbeschreibung Des Preußischen Veteranen Johann Christian Schimmel.," Zeitschrift Für Kunst, Wissenschaft, Und Geschichte Des Krieges, Vol. 10, No. 4-6 (1827): 189.

${ }^{7}$ For an excellent summary of Blücher's early career, see: Michael V. Leggiere, Blücher: Scourge of Napoleon, (Norman, University of Oklahoma Press: 2014), 3-35.

${ }^{8}$ Schimmel, "Kurze Lebensbeschreibung," 189.
} 
different meanings regarding his military service, meanings that shifted from the mid-eighteenth century through the Napoleonic era and the Restoration. With that said, the factual outline of service provided by Schimmel, as well as passing comments placed in the narrative, can provide details regarding some aspects of military life, particularly the experience of being a Prussian prisoner of war during this era.

The third source from common soldiers in the Regiment von Itzenplitz comes from two relatives (an uncle and a nephew) from the village of Nitzahn. These soldiers wrote to their relatives, who were Dorfschulzen, or village elders, and as a result represent writings from a prominent peasant family in a small village in Brandenburg. The letters from the Zanders were uncovered in 2014 and published by a living descendant of these soldiers. Despite their relatively recent rediscovery, these letters have been thoroughly analyzed by Katrin and Sascha Möbius. ${ }^{9}$ They provide an important window into the life of soldiers in the Regiment von Itzenplitz, for several important reasons. First, rather than recollections compiled forty or seventy years after the events in question, the letters were penned chronologically close to the events they describe. Second, rather than providing a concrete story narrative from start to finish, the letters are full of requests, doubt, and rumor: they show the agency of history still in motion. Third, these letters provide the important perspective of soldiers who did not survive conflict. These factors provide historians with a view of common soldiers in the Itzenplitz regiment not provided by other sources.

\footnotetext{
${ }^{9}$ Katrin and Sascha Möbius, Prussian Army Soldiers and the Seven Years War: The Psychology of Honour, (London: Bloomsbury Academic, 2020) 62; Forthcoming, Katrin and Sascha Möbius, "Fighting in Frederick II's favorite musketeer regiment: A unique series of Prussian soldiers' letters from the Seven Years War" in Redefining Eighteenth-Century Warfare: A Festschrift for Christopher Duffy, (Helion \& Co, 2022).
} 
When taken together, this collection of sources, although still meager when compared with what is available to historians working on unit histories in the nineteenth and twentieth centuries, provide a firm foundation for constructing a history of the Regiment von Itzenplitz from below. The soldiers of this regiment constituted a complex group of men from diverse backgrounds and experiences, and this is true even with the four voices present with these sources. Using these four voices, historians can identify a foreign recruit who was potentially conscripted in dubious circumstances, a willing foreign volunteer from a neighboring state, and two conscripted though loyal prominent peasants, the cantonists which formed the backbone of the Prussian Army during the Seven Years War. These voices provide historians with a diversity of experience: a deserter, a loyal veteran who grew gray in the service, and two men who perished in their fight for their homeland and king. The chapter will first examine the background of the regiment and its commander, and then move into the stories provided by this collection of mid-eighteenth-century common soldiers.

\section{REGIMENTAL HISTORY}

The Regiment von Itzenplitz was not a "famous" military unit after the manner of Alexander's Companions, Napoleon's Imperial Guard, or the $442^{\text {nd }}$ Regiment Combat team, but it has consistently garnered the notice of historians as a result of the reputation it acquired and the literate men within its ranks. In one of the strange ironies of the Seven Years War, the Regiment von Itzenplitz found itself forced to attack Austrian Croats entrenched on high ground in two separate battles: both the regiment's first and one of the last battles of the conflict. On

October 1, 1756, the unit found itself attacking the Lobosch Hill northwest of Lobositz, in the modern Czech Republic. On July 21, 1762, the regiment attacked the hills south of Dittmannsdorf, during the Battle of Burkersdorf, in modern Poland. It might be easy to assume 
that an aggressive command culture permeated the regiment, or that by 1762 , most of the soldiers were experienced veterans, but this is not the case. Indeed, very few enlisted men who served in 1756 remained with the regiment until 1762 as a result of disease, desertion, and enemy action.

The military history of the Itzenpltiz Regiment in the Seven Years War can be broken down broadly into three periods: the "first" regiment, from 1756-1758, regimental recovery in 1759, and then the "second" regiment from 1760-1762. The soldiers of the "first" regiment did indeed gain veteran status but were largely wiped out in the disaster at Hochkirch in 1758. After being re-raised, the regiment was slowly re-acclimated to combat operations, before being sent into the fight at the battles of Torgau and Burkersdorf. The four soldiers mentioned above primarily served during the period of the "first" regiment, and so the focus of this chapter will largely highlight the two years between 1756 and 1758 .

The Itzenplitz Regiment, or IR 13, possessed a long and proud history before the Seven Years War. In the late seventeenth century, the thirteenth infantry regiment was formed from Huguenot refugees in Prussia, who had been welcomed by the Great Elector. During the War of Spanish Succession, the regiment fought in the Netherlands, and it also earned distinction at the Battle of Hohenfriedberg in the War of Austrian Succession, fighting in the first line of battle. Prussian common soldiers cared about the particular histories and distinctions of their units. Soldiers were trained to respect and honor the flags of their regiment. Each company possessed a flag, and soldiers took their oath of service to the Prussian military while touching one of these regimental flags. Frederick himself wrote that regimental pride was the most important factor in the new mode of combat developing after the Seven Years War: "As for the soldier, the best one can do is give him a sense of esprit de corps, that is to say, make him think that his regiment 
consists of the best soldiers in the universe. ${ }^{10}$ This was certainly achieved; even soldiers who deserted from their regiments remembered the units with fondness. Bräker, even after deserting from Regiment von Itzenplitz, still possessed a sense of unit pride thirty years later, calling Itzenplitz, "a noble name." ${ }^{11}$ Joseph Dreyer recalled wanting to do his duty to the utmost, not only "to gain the love of my superiors, but also the respect of my comrades." As Sascha Möbius has suggested, loyalty to their unit and comrades mattered more to Prussian soldiers than fear of their officers. ${ }^{12}$

The Itzenplitz regiment's fearsome reputation is often attributed to the commanding presence of General August Friedrich von Itzenplitz, the regimental Chef, or Colonel-Proprietor, who gave the regiment its name. ${ }^{13}$ During the War of Austrian Succession prior to his leadership, however, the unit performed well during the War of Austrian Succession. During the first battle of Frederick's wars, Mollwitz, the regiment was stationed in the left wing of the first line of Prussian infantry. During the Battle of Hohenfriedberg, the unit fought on the leading edge of the Prussian formation, near the Guard Regiment and Grenadier Guard Regiment. At the final battle of the war, the Battle of Kesselsdorf, the regimental commander, Major General Samuel von Polentz, died of wounds while leading his men into combat. ${ }^{14}$ Polentz's demise created a vacancy, which was filled by Major General August Friedrich von Itzenplitz. August Friedrich von Itzenplitz enlisted in the Prussian army in 1709 as a private, at age 16. He was assigned to an infantry regiment, sources disagree on whether this was IR 12 or IR 13 , the unit

\footnotetext{
${ }^{10}$ Friedrich II and Gustav Berthold Volz, Die Politischen Testamente Friedrich's Des Großen (Berlin: Hobbing, 1920) 147.

${ }^{11}$ Bräker, Lebensgeschichte, 141.

${ }^{12}$ Sascha Möbius, Mehr Angst vor dem Offizier als vor dem Feind? Eine mentalitätsgeschichtlche Studie zur preussischen Taktik im Siebenjährigen Krieg (Akademiker: Mauritius, 2007).

${ }^{13}$ Christopher Duffy, The Army of Frederick the Great, $2^{\text {nd }}$ Edition, (Chicago: Emperor's Press, 1994$) 76$.

${ }^{14}$ Anton Balthasar König, Biographisches Lexikon aller Helden und Militairpersonen, (Berlin: Wever, 1790)3:190.
} 
which would later bear his name. ${ }^{15}$ After the Seven Years' War, and in the mid-nineteenth century, it was thought that he first served in IR 13. Itzenplitz served with distinction in the War of Spanish Succession and was present at the bloody battle of Malplaquet in 1709. He transferred to leadership in 1715, when he was promoted to the rank of Ensign. By the time Frederick the Great ascended to the throne in 1740, Itzenplitz was an experienced junior officer, of the type which would carry Prussia to victory in the mid-eighteenth century. He served with distinction at the Battle of Mollwitz, and commanded both the IR 29 and IR 1 in the War of Austrian Succession. Itzenplitz met his greatest success in this conflict at the Battle of Hohenfriedeberg, where he commanded IR 1, which exploited the charge of the Bayreuth Dragoons, and won the Pour le Mérite. ${ }^{16}$

Itzenplitz was promoted to Major-General in the summer of 1750, and received the unit who would bear his name, IR 13/von Itzenplitz, in 1751. At the beginning of the Seven Years War, he consistently held a brigade command, and successfully commanded infantry assaults at Lobositz, Prague, and Rossbach. At Rossbach in particular, he earned distinction, as he commanded a brigade of Grenadier battalions in Prussian first line, and his troops captured a battery of five cannon. Itzenplitz missed the Battle of Leuthen, remaining in Saxony to observe the French and Reichsarmee, a sign that Frederick II viewed him as having potential for independent command. Itzenplitz gained further notoriety in the retreat from Bohemia after the Battle of Kolin. A battery of Prussian guns was left exposed to a mixed force of Croats and mounted troops in the withdrawal from Prague. Itzenplitz, in response, rode up to the guns with a

\footnotetext{
${ }^{15}$ IR (Infanterie Regiment) followed by a numerical designation, was a method of naming the old Prussian infantry regiments developed in the late-eighteenth century. IR 13 refers to the Regiment von Itzenplitz.

${ }^{16}$ Eduard Lange, Die Soldaten Friedrich's Des Großen (Leipzig: Avenarius \& Mendelssohn, 1852), 57.
} 
single adjutant, and remained with the gunners until the artillery was safely withdrawn. Itzenplitz and his adjutant were exposed to a heavy fire, and his aide received a minor wound.

In 1758 , he was given independent command of a corps of 12,000 men, which he led in a march to join King Frederick's army. For successfully organizing this independent command, he was awarded the order of the Black Eagle, the highest honor for Prussian nobility. In 1759, he successfully raided Imperial territory, before meeting his end during the disaster at Kunersdorf. At Kunersdorf, he commanded the center right division of the second infantry line, behind Johann Dietrich von Hülsen. In this battle, he received a non-fatal wound to the head, but his leg was mangled when his horse collapsed on him, and he took a musket ball through the hand. Together, these wounds forced the 76-year-old general to succumb to blood loss, and he was taken off the field. Itzenplitz died a month after the battle from these wounds and was recognized by contemporary Prussians as a hero. ${ }^{17}$

\section{REGIMENTAL RECRUITMENT}

The common soldiers of Itzenplitz's regiment came from a variety of backgrounds. Two large sources of men were native cantonists, and foreign volunteers or conscripts. Cantonists, such as the Zanders, had both joined the regiment by 1750. The Zanders, an uncle and nephew, highlight that the Prussian Army could be a family affair for the cantonists, and their peacetime letters are full of developing family connections, concerns regarding clothing, and efforts to be fairly treated by regimental officers. ${ }^{18}$ This process of having relatives in arms - brothers, cousins, uncles, nephews, even fathers and sons - was very common for the Prussian Army.

\footnotetext{
${ }^{17}$ Ibid, 58.

${ }^{18}$ Christian F. Zander, Fundstücke - Dokumente Und Briefe Einer Preußischen Bauernfamilie: (1747 1953) (Hamburg: Kovacì, 2015), 21-23.
} 
Indeed, Sergeant Liebler, a Pietist soldier described in chapter five, was accompanied by his son, in the same regiment. ${ }^{19}$ Veteran and author Georg Friederich Tempelhof described the process:

If you want to take the trouble, you can easily convince yourself of this fact. There is nothing more common than a mother with two, three, or more sons who have gone for soldiers. If you ask her, 'where are they?' she answers you with a certain satisfaction: 'I have three in the regiment. The oldest is flankman of the company, the second is five foot ten inches, the youngest five foot eight inches, but he is only just 18 years old."' 20

With this type of familial arrangement, any disastrous battle would have been catastrophic for the village community.

Johann Schimmel also drew on family connections as he entered the Prussian army. His father had been an oboist in the $1^{\text {st }}$ Battalion of the Saxon Garde Regiment. Schimmel became interested in music, and his father taught him to play. At age twenty-six, Schimmel enlisted in the Itzenplitz Regiment, as a trumpeter. ${ }^{21}$ Ulrich Bräker took a long and winding road into the Prussian army, initially signing on to be an officer's servant, traveling across the empire before reaching Berlin. It is often recorded that Bräker was "tricked" into joining the army, dragooned, or misled. When read carefully, Bräker's forcible enlistment seems to have resulted from an expensive and failed recruiting expedition led by Lt. Markoni. When the staff officers of the Itzenplitz Regiment realized that Markoni had been living the high life in the Swiss Confederation and had very little to show for his efforts, Bräker was inducted into the army in order to recoup this expense. When Bräker petitioned his major for redress, he received this

\footnotetext{
${ }^{19}$ Curt Jany, Urkundliche Beiträge Und Forschungen Zur Geschichte Des Preussischen Heeres (Berlin: E.S. Mittler, 1901) 34.

${ }^{20}$ Georg Friedrich von Tempelhoff, Geschichte Des Siebenjährigen Krieges in Deutschland Zwischen Dem Könige Von Preußen Und Der Kaiserin Königin Mit Ihren Alliirten, vol. 2 (Berlin: Unger, 1785), 9.

${ }^{21}$ Schimmel, "Kurze Lebensbeschreibung," 189.
} 
reply: "Your fine master has mismanaged his money, and no doubt you got your share. In short, you are to serve the King now, and that's the last I will hear of this!",22

Bräker, Schimmel, and the Zanders display the three most common methods of recruiting men for the Itzenplitz Regiment, and by extension, the Prussian army. Forcibly enlisted nonPrussians like Ulrich Bräker left the largest impact on the image of the Prussian army, but were a minority compared to volunteers and native cantonist conscripts. Forcibly enlisted men were the greatest desertion risk to the Prussian army, and they fled the Prussian army in large numbers, as Marcus von Salisch has shown. Men serving against their will were quite a liability to the Prussian army, and became a serious danger to the cohesiveness of the army after the forcible incorporation of Saxon prisoners of war at Pirna in $1756 .{ }^{23}$ On the other hand, foreign (nonPrussian) soldiers such as Schimmel served as volunteers quite frequently. They came from all over German Central Europe; there were Saxons, Alsatians, Anhaltiners, Swiss, French and Italians. Many later recalled serving in the Prussian army with great fondness. ${ }^{24}$ Finally, there were native volunteers and conscripts, of which the conscripted cantonists made up the largest portion. Although these men were not always enthusiastic soldiers, they were capable of great animation during combat, and as I have shown in chapter five, developed a special bond with Frederick II.

There were certainly differences in peacetime experiences between these four men in the Itzenplitz Regiment. The regimental group could comfort soldiers who were not comfortable in their service in the Prussian army. As a recruited foreigner, Ulrich Bräker did not always work

\footnotetext{
${ }^{22}$ Ulrich Bräker, Lebensgeschichte Und Natürliche Abentheuer Eines Armen Mannes Von Tockenburg (Zurich: Hans Heinrich Füssli, 1789), 117.

${ }^{23}$ Marcus Von Salisch, Treue Deserteure: Das Kursächsische Militär und Der Siebenjährige Krieg (München: R. Oldenbourg, 2009), 139-156.

${ }^{24}$ Anonymous., Offizier-Lesebuch, Historisch-militärischen Inhalts, Mit Untermischten Interessanten Anekdoten, Von Einer Gesellschafts Militärischer Freunde (Berlin: C. Matzdorff's Buchhandlung, 1793), 185.
} 
well with his officers. His colonel and captain terrified him, and he seems to have hated the culture of Berlin. Despite these challenges, Bräker did indeed find a group of soldiers he could confide in: fellow Swiss soldiers. He recalled, "In the second week I had to present myself every day at the parade ground, where I encountered three of my countrymen by chance." ${ }^{25}$ He found that two of them, Schärer and Bachmann, were assigned to his same company. These three soldiers would become close friends. Bräker indicates that there were other Swiss troops in the regiment, but because they were not in his company, it was difficult to make contact with them. Despite not being assigned to the same mess group, Bräker recalled that he, Schärer, and Bachmann, "often walked out of the camp as far as the outposts... there we held a council of war as to what we should do, where we should make our escape... and where we should meet up again." ${ }^{26}$ These Swiss soldiers used regional affinity as a framework for determining whom they could and could not trust, and to make army life more tolerable.

\section{THE SEVEN YEARS WAR}

The literate soldiers in the Itzenplitz Regiment experienced the outbreak of the Seven Years War in different ways, associating it with different emotions based on the nature of their service in the Prussian army. Ulrich Bräker described the emotions that the soldiers felt upon leaving Berlin, saying: "Now the march struck up, and there were heaps of flowing tears from the citizens, soldiers' wives, and whores. Also the men of war themselves, principally the native sons, who were leaving wives and children behind became totally downcast, full of sadness and sorrow. ${ }^{, 27}$ Even while sympathizing with his fellow-soldiers who were native Prussians, Bräker secretly rejoiced at the outbreak of war, for it potentially afforded him and other recruited

\footnotetext{
${ }^{25}$ Bräker, Lebensgeschichte, 122.

${ }^{26}$ Ibid, 144.

${ }^{27}$ Bräker, Lebensgeschichte, 138.
} 
foreigners a better opportunity to desert from the army. Christian Friedrich Zander wrote his brother Johann a letter just before the onset of war, and took an anticipatory, almost nervous tone. "They say that the Saxons will not let us pass through to Silesia, that is why it [a war] will soon start, God only knows where we will be led." ${ }^{28}$ Although it was not necessary for Saxony to allow the passage of Prussians into Silesia, Zander notes a general resistance to Prussian encroachment. He was clearly not excited or triumphalist about the war, and his tone appears anxious. Schimmel recalled the importance of local connections at the outset of the Seven Years War. As a native Saxon Schimmel felt strong sympathy towards the Saxon opponents of Prussia in the early Seven Years' War. He was a native of Saxony, born in Herzberg near Torgau in $1729 .{ }^{29}$ Schimmel displayed his sense of Saxon localism: "We thought, as we entered Saxony, 'Better to have the Saxons with us than against us!"' ${ }^{30}$ He later acknowledged satisfaction at gaining Saxon comrades in arms after the capitulation at Pirna. Schimmel clearly felt an attachment to the people of Saxony, even as he and his Prussian comrades waged war on the Saxon state.

Historians have used Ulrich Bräker's description of the behavior of the Itzenplitz regiment on the march to Saxony at the outset of the Seven Years War as evidence that soldiers developed a sense of martial masculinity which was hostile to civilians. During the march, the men stopped at a number of villages, although Bräker dwells specifically on the night in the village of Köppernick. Indeed, the passage indicates the aggression shown by hungry soldiers, who intimidated civilians into bringing out hidden stores of food. This should not be confused with the violence and chaos experienced during the Napoleonic Wars, where goods were often

\footnotetext{
${ }^{28}$ Zander, Fundstücke, 28.

${ }^{29}$ Schimmel, "Kurze Lebensbeschreibung," 189.

${ }^{30}$ Ibid.
} 
taken by threat of force. ${ }^{31}$ Thirty to fifty soldiers were quartered per house and heads of household were paid a groschen per man in order to feed the soldiers. This total sum, although perhaps a bit stingy, far exceeded a day's wage. In addition, Bräker notes that one officer was placed in each house in order to ensure that civilians were treated with respect, although he also notes that they were often rude to civilians themselves. ${ }^{32}$ These nights could be crowded; indeed, Christian Zander recalled a few nights later that, "it is a bad time here, 30-40 men sleep per house... the towns and villages are full of soldiers, and one does not even have room to write a letter, so I have written this one in the garden." 33 When Bräker's account is compared with Zander's, it does not appear that this was an instance of a forceful masculine identity running rough-shod over civilians. Rather, it was a frustrating time for all concerned, with some soldiers aware of civilian hardship, and Zander noticing the residents' discomfiture.

As the Prussians invaded Saxony, the Austrian forces under Field Marshall Browne attempted to intervene. The resulting Battle of Lobositz was the only battle all four men experienced together. The scrambling hillside battle was the first major confrontation of the Seven Years War. While Schimmel speaks only briefly regarding the Austrian defeat at Lobositz, and the letter which Christian Friedrich Zander wrote directly after the battle on November 5, 1756 has not been persevered, fortunately Bräker provides a much fuller accounting of the battle. ${ }^{34}$ Moving out of their camp, the regiment advanced into the misty Lobositz valley, and took their place on the Prussian right flank.

Until now, I had the hope that I would escape from being in a battle, but I no longer saw any prospects of escape. We moved forward continuously. My

\footnotetext{
${ }^{31}$ Jakob Walter and Marc Raeff, The Diary of a Napoleonic Foot Soldier (Moreton: Windrush, 1999), 4-7.

${ }^{32}$ Bräker, Lebensgeschichte, 139.

${ }^{33}$ Zander, Fundstücke, 28.

${ }^{34}$ Ibid, 31.
} 
courage deserted me. I would like to have been able to disappear into a hole in the ground, and I saw a similar fear on the faces of others, even those who had previously boasted of their courage. Empty flasks sailed through the air as soldiers finished them, and they said, 'courage for today, and perhaps no need of it tomorrow!' Now we advanced under artillery and took over a place in the first line of battle. By heaven! How the iron flew over our heads, knocking holes in the ground and kicking up stones and earth! ${ }^{35}$

Initially confronted by enemy cavalry, the troops allowed friendly cavalry to pass by

them, in order to engage the enemy. The Prussian cavalry was defeated and retreated toward the infantry line. Despite the defeat of the Prussian cavalry, neither side gained a decisive advantage and the battle continued. From the opening skirmishes at 8 a.m., the regiment was bombarded by enemy artillery until 11 a.m., and then began to hear small arms fire away on the left flank. A short while later, orders came for the Itzenplitz Regiment, as well as the Regiments of Bevern and Kalckstein, to move to the rear in order to support the fighting on the left flank. This battle was primarily a contest between infantry over the Lobosch hill. Austrian troops entrenched in walled vineyards on the high ground fired down into Prussian infantry, who were running out of ammunition. ${ }^{36}$ The type of soldier the Austrians deployed were Pandours, soldiers from the southeastern military borders of the Austrian Empire who possessed great skill at fighting in difficult terrain and irregular warfare.

\footnotetext{
${ }^{35}$ Bräker, Lebensgeschichte, 148.

${ }^{36}$ Christopher Duffy, By Force of Arms: The Austrian Army in the Seven Years War, (Chicago, Ill: Emperor Press, 2008), 2:28.
} 


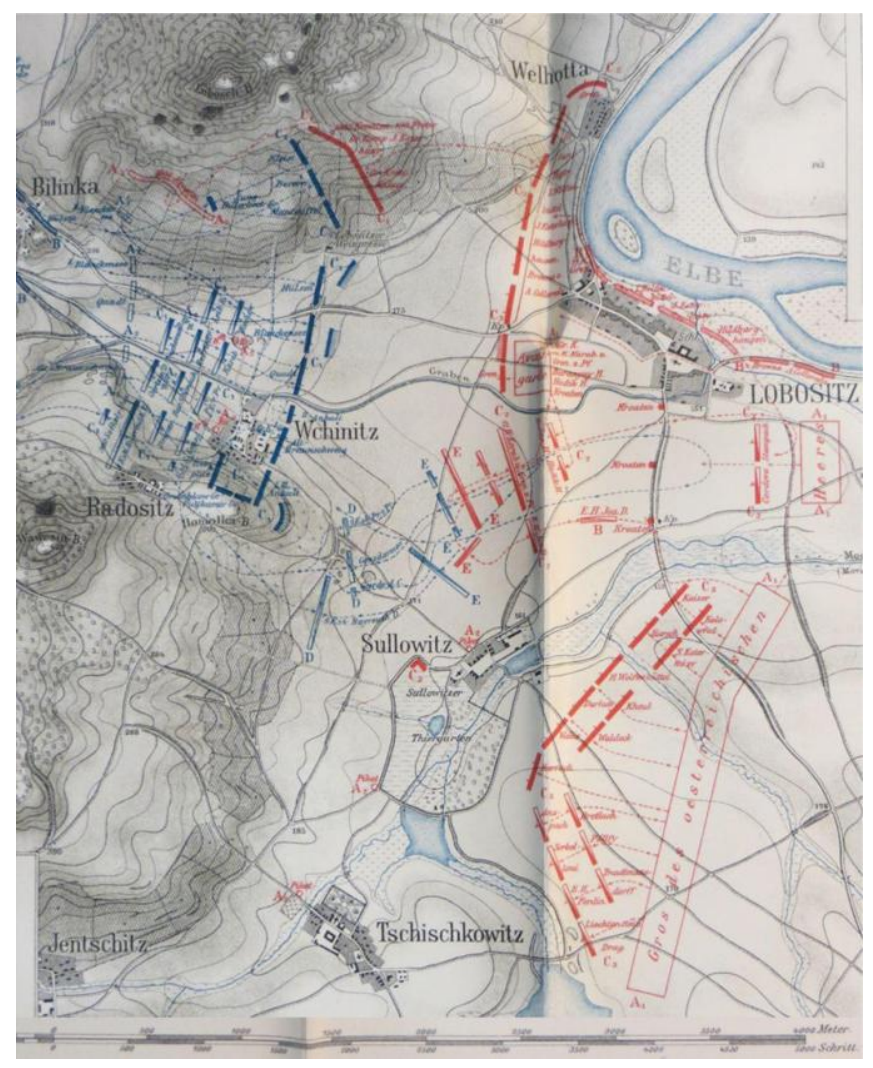

Figure 1: This image from the Grosser Generalstab History of the Seven Years War shows the forces at approximately 8 a.m. on October 1, 1756

As the Itzenplitz Regiment moved to the northern end of the battlefield on the left flank of the Prussian army, Bräker and his comrades initially believed that they were being sent out of the fight. He describes soldiers picking grapes from the vineyards as they marched along.

However, the scene soon changed:

We saw our brother-soldiers standing amongst enemy fire, saw the flash of smoke from the top of the heights, heard a thunderous clattering and could not tell who was getting the better of the fight. In the meantime the officers led us further up the heights...our advanced troops neared the summit, and there was suddenly a fury of musket fire. We knew were we in a terrible mess... [and] now began an indescribable bloodbath as we needed to drive the Pandours from the grove. ${ }^{37}$

Bräker's formulation of "brother-soldiers" is one of many signs, as Jürgen Kloosterhuis has demonstrated, that he internalized much of the camaraderie and soldierly self-confidence which

${ }^{37}$ Bräker, Lebensgeschichte, 149. 
military service provided to Prussians in the mid-eighteenth century. His statement, "we knew we were in a terrible mess," is indicative of the sinking feeling of soldiers approaching battlefield small-arms range during the eighteenth century.

The Austrians sent reinforcements to the forces on their right flank, hoping to force a Prussian withdrawal by threatening the rear of the Prussian army. According to Bräker, the Itzenpltiz Regiment intercepted these troops and a sharp fight developed. The Prussian infantry, which had been on the left flank since morning, were beginning to run out of ammunition. The units had become intermixed, and officers began to command soldiers nearest to them as opposed to their individual regiments. ${ }^{38}$

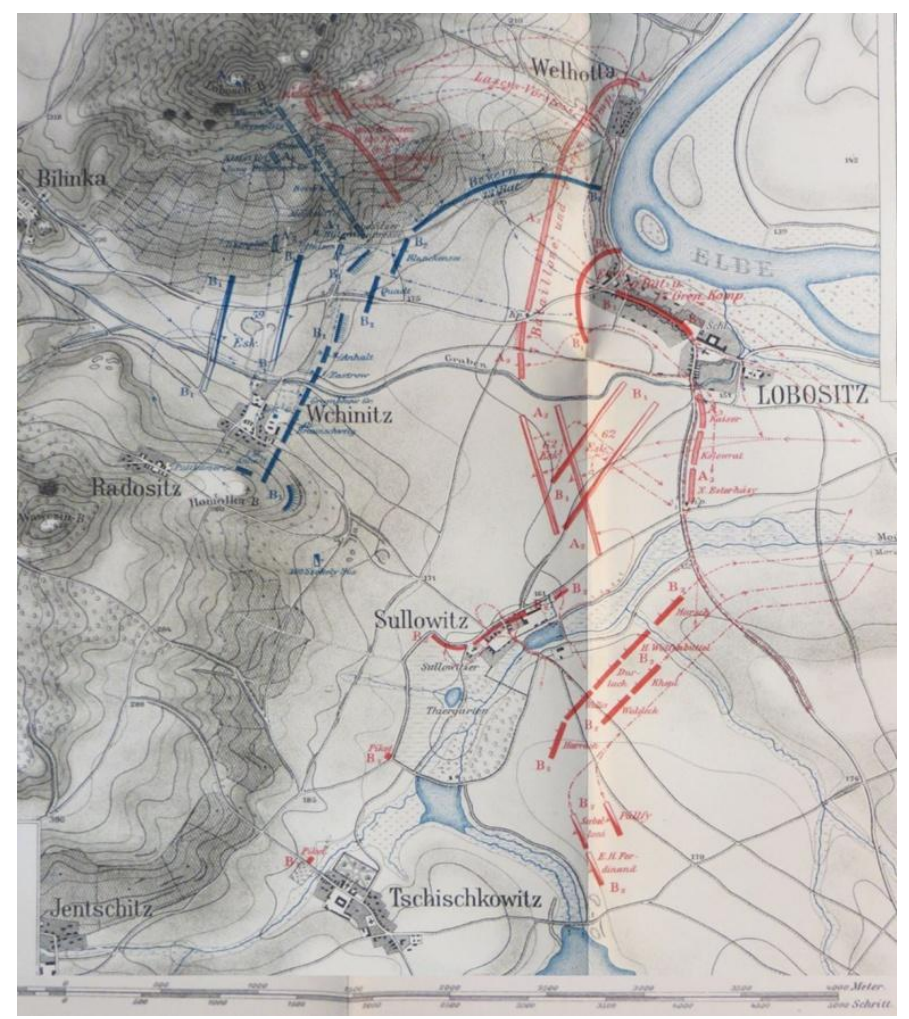

Figure 2: This image from the Grosser Generalstab History of the Seven Years War shows the forces at approximately 1 p.m. on October 1, 1756

\footnotetext{
${ }^{38}$ GStAPK IV HA Rep. 15A, Nr. 610, Rélation von der Bataille von Lowositz am 1ten Oktober 1756.
} 
The Prussian commander of this portion of the army, Duke August Wilhelm von Braunschweig-Bevern, launched his troops into a desperate bayonet attack after his men had exhausted their ammunition. The Duke of Bevern's secretary, Kirstenmacher, described the scene in a letter:

Bevern was everywhere at once. Acting as an inspiration in the strongest fire, he rode from regiment to regiment and saw how the troops who were not in close order because of the terrain, but instead fought in little groups... were not replying to the enemies' heavy fire. "My boys," the Duke called to them, "shoot, for God's sake, shoot and advance!" "Ach, dear father," they replied, "what can we do? We are out of powder and can't fire back!" "What," cried the Duke, 'don't you have bayonets, go strike the dogs dead!"39

In the years after the war, veterans would associate the bravery of the Duke with the Itzenplitz Regiment. Friederich August von Retzow, a young officer present with the army, recalled in 1802 that "the Duke stood with all the level headedness he had displayed at Lobositz, at the head of the Itzenplitz Regiment."40

Braker recalled this particular moment of the action, stating that "our native Prussians and Brandenburgers sprang upon the enemy like furies."41 This turn of phrase is interesting, as even in the heat of combat, Bräker associated regional origin and fighting spirit. One can easily imagine Christian and Johan Zander being caught up in the heat of the moment, even as Bräker started to edge towards the metaphorical door. Bräker described the strain and high of combat, stating that, "I felt myself overcome by heat and adrenaline, and unconscious of fear or terror, fired away all my sixty cartridges, so that my musket became so hot I had to carry it by the sling.

\footnotetext{
${ }^{39}$ Curt Jany, Urkundliche Beiträge Und Forschungen Zur Geschichte Des Preussischen Heeres (Berlin: E.S. Mittler, 1901), 9-10.

${ }^{40}$ Friedrich A. von Retzow, Charakteristik Der Wichtigsten Ereignisse Des Siebenjährigen Krieges, in Rücksicht Auf Ursachen Und Wirkungen, I (Berlin: Himburg, 1802), 231.

${ }^{41}$ Bräker, Lebensgeschichte, 150.
} 
But I don't think that I hurt a living soul, it all went into thin air."42 Marian Füssel has identified this type of sentiment, an absolution of personal responsibility for harming others in combat, as typical in the writings of eighteenth-century soldiers. ${ }^{43}$ Prussian troops continued to press their advantage, chasing the Austrians back through the town of Lobositz, and eventually forced the Austrian army to withdraw. This phase of the Battle of Lobositz demonstrates incredible flexibility on the part of Prussian soldiers. Far from being constrained by their officers and only envisioning combat occurring in the rigid lines of linear warfare, these soldiers continued to operate even after the cohesion of regimental organization had broken down. Soldiers fired independently, with some forces pressing the enemy with bayonet attacks, while others stayed on higher ground and fired at enemy troops. ${ }^{44}$ Unlike the Battle of Mollwitz fifteen years earlier, Prussian troops in combat easily conceived of combat outside the orderly firing of platoons. ${ }^{45}$

Near the end of the Battle of Lobositz, Ulrich Bräker managed to slip away from the Prussian army and desert to the Austrians. The campaign season did not end for the men of the Itzenplitz Regiment after this dramatic battle, but continued when on the $24^{\text {th }}$ of October, the Regiment was attacked on the Elbe River. Frederick II reported,” Itzenplitz's Regiment was attacked at night while guarding the river Elbe near the village of Salesel. They defended themselves so well that they were not content to merely repulse the enemy but took many prisoners." ${ }^{46}$ Even at this early stage in the war, Frederick II indicated that the Itzenplitz Regiment was a superior fighting force.

\footnotetext{
${ }^{42}$ Ibid.

${ }^{43}$ Marian Füssel, "Emotions in the Making: The Transformation of Battlefield Experiences during the Seven Years War" in Battlefield Emotions 1500-1800: Practices, Experience, and Imagination, eds. Erika Kuijpers and Cornelius van der Haven, (London: Palgrave Macmillan, 2016) 153.

${ }^{44}$ Ibid.

${ }^{45}$ Christopher Duffy, The Military Experience in the Age of Reason (New York: Atheneum, 1987), 212.

${ }^{46}$ Friedrich II, Oeuvres de Frederic le Grand, (Berlin: 1847) 4:98.
} 
The Itzenplitz Regiment was quartered near Dresden during the winter of 1756-1757, and Christian Zander took the opportunity to write his cousin about army life on November 24, 1756. Some of the troops were quartered near the magazines in the middle of the city, and Christian Zander recalled wonder at seeing the exotic animals in the Tierpark near the Jägerhof. ${ }^{47}$ Here, historians can observe the vitality of letters over memoirs when practicing new military history. Though Schimmel provides a curt and gruff military narrative, and Bräker describes the Battle of Lobositz vividly, the letters of the Zanders provide historians with a window into how common soldiers experienced the largesse of military life. It is easy to describe such letters as mundane, but they provide a window into the broader dimensions of military experience and should certainly not be dismissed. Zander described the architecture and wonders of Dresden, as well as the clothing which his regiment obtained, and of course, always pleaded for return letters: "We have received good cloth breeches, which we enjoyed, and you should take the time to write us back soon." ${ }^{48}$ Schimmel seems to have found something enjoyable during his winter in Dresden, implying that there had been "dancing in Dresden." 49 The Zanders' letters from Dresden contain personal messages to family as well as anecdotes about famous people, the progress of the war, and strange events. In a letter from December 4, 1756, Christian Zander described the departure of the Polish Queen and Saxon Electress Consort, Maria Josepha of Austria, with three of her sons, for Poland. Johan Zander's December $14^{\text {th }}$ letter describes the movements of enemy Pandours, whereas Christian Zander's letter from December $22^{\text {nd }}$ spins a story about the discovery of two large chests of Hungarian Jesuit gold by Hussars. These were relatively peaceful months for the men of the Itzenplitz Regiment, and in a city such as Dresden, the Zanders rarely found winter quarters boring as they wrote to their families regarding their

\footnotetext{
${ }^{47}$ Zander, Fundstücke, 32.

${ }^{48}$ Ibid.

${ }^{49}$ Schimmel, "Kurze Lebensbeschreibung," 191.
} 
broader military experiences. ${ }^{50}$ Indeed, the winter of $1756-1757$ made deep impressions on the men of the Itzenplitz regiment.

On February 11, 1757, the Zanders reported that their unit was moving south, and had come within six miles of the Bohemian border. Although technically in control of the province of Saxony, this border region was more difficult for the Prussians to police, and the men of the regiment were somewhat surprised that they had been sent here, as opposed to Silesia. ${ }^{51}$ During the time of this expedition, a large party of eight hundred Hungarians and Pandours attacked a party of two hundred men. During this skirmish, Captain [Bogislav von] Miltitz was wounded, and the regiment took thirty-two casualties. ${ }^{52}$ As Katrin and Sascha Möbius have argued, Christian Friedrich Zander provided a relatively brief description. He chose to focus on the honor paid to the regiment, obscuring the violence of what must have been a dangerous close encounter between Prussian and Austrian troops. Zander conveyed the dishonorable behavior of the enemy, the honorable behavior of the Prussian troops as recognized by the king, and the sufferings of his fellow soldiers. ${ }^{53}$

Frederick's decision to invade Bohemia in the spring of 1757 was certainly a gamble, and the papers of Prussian General Hans Karl von Winterfeldt make it appear that this decision was taken relatively late. In his characteristically short fashion, Schimmel indicates that the Prussians surprised the Austrians as they invaded Bohemia. ${ }^{54}$ Johann Diedrich Zander's letter from April $12^{\text {th }}$ (less than a month before the large battle at Prague) is more circumspect, suggesting that the

\footnotetext{
${ }^{50}$ Zander, Fundstücke, 40-45.

${ }^{51}$ Ibid, 46.

${ }^{52}$ Ibid, 49

${ }^{53}$ Möbuis, Prussian Army Soldiers, 204.

${ }^{54}$ Schimmel, "Kurze Lebensbeschreibung," 190.
} 
king was mobilizing a large army, but that he had little idea of where that army would go. ${ }^{55}$ Frederick's invasion of Bohemia resulted in the Battle of Prague, on May 6, 1757. Schimmel provides a curt description of the run-up to the battle, suggesting that Frederick may have addressed the regiment in passing, as described in chapter three. ${ }^{56}$ The battle itself was bloody, often remembered by jingoistic Prussian historians for the famous martyrdom of Kurt Christoph von Schwerin, a humane and talented general, a generation older than Frederick II. Although the main Prussian attack bogged down in the face of fierce Austrian opposition, Prinz Heinrich and the Itzenplitz Regiment launched an unlikely attack through streams and marshy ground in order to seize an Austrian cannon battery. Christian Friedrich Zander did not describe the battle, but describes being "severely ill" in the days following the battle, writing that "all eyes watching thought I would die." 57 During his sickness, Christian received news of the disastrous Prussian defeat at Kolin, and described that battle in a letter to his cousin on July 21, 1757. The Austrian victory forced the Prussian army onto the defensive, and Frederick now abandoned his siege of Prague and moved his army back into Saxony and Silesia. The hardships of military life were again brought home to the veteran Zanders. During September 1757, the pace of the march meant the baggage train with its tents failed to reach the Itzenplitz. Christian wrote to his family, "We spent the whole night under the open sky, next to our weapons. It rained the whole night, so that one became very stiff." ${ }^{58}$ Despite this, the Zanders did not seem to link their hardships overtly with despondency or resentment toward the king, as chapter five has discussed with respect to the broader army.

\footnotetext{
${ }^{55}$ Zander, Fundstücke, 52.

${ }^{56}$ Schimmel, "Kurze Lebensbeschreibung," 189.

${ }^{57}$ Zander, Fundstücke, 53.

${ }^{58}$ Ibid, 62.
} 
This began a four-month period, where despite increasing adversary, Frederick won two major battles, Rossbach in Saxony, and Leuthen in Silesia. Schimmel recalled this triumphant phase: "Now the French and the people of the Empire (the army of the Holy Roman Empire, or Reichsarmee) thought they were going to defeat us, reach Berlin, and eat hot rolls. But how they ran at Rossbach! I heard from them no more." 59 At Rossbach, the first battalion of the Itzenplitz Regiment was placed in the advanced guard. By that time, other regiments had begun to think of Itzenplitz as an elite formation, and young officer Ernst von Barsewisch in the Meyerink Regiment recalled, "this was also the reason why His Majesty the King entrusted this important post and first attack to us and the battalion of Itzenplitz, which also belonged to one of the best regiments in the army." ${ }^{\prime 00}$ The Itzenplitz Regiment had gained a well-known reputation, largely by fighting in a number of actions. In the eighteenth century, military theorists did not necessarily believe that repeated exposure to combat made for better or experienced veteran soldiers, but Frederick's continued use of Itzenplitz in the forefront of the battles of 1756-1757 did much to create a fearsome reputation for this unit within the army. ${ }^{61}$

The winter of 1757-1758 was trying for the men of the Regiment, and on January 29, 1758 Christian Friedrich Zander explained to those at homethat "one is very cold during watches, which feel long because we have no overcoats." ${ }^{62}$ Johann followed this letter with one of his own, asking for two new breeches, two knitted pairs of socks (stockings), and a new cap. He indicated to his mother and family that he had marched over two hundred miles, and had no

\footnotetext{
${ }^{59}$ Schimmel, "Kurze Lebensbeschreibung," 190.

${ }^{60}$ Ernst von Barsewisch, Meine Kriegs-Erlebnisse Während Des Siebenjährigen Krieges 1757-1763 ; Wortgetreuer Abdruck Aus Dem Tagebuche Des Kgl. Preuß. General-Quartiermeister-Lieutenants C.F.R. Von Barsewisch (Berlin: Warnsdorff, 1863), 34.

${ }^{61}$ Duffy, Military Experience in the Age of Reason, 252.

${ }^{62}$ Zander, Fundstücke, 63.
} 
stockings, and had shoes full of holes. ${ }^{63}$ Schimmel described this period as "the first peace" the Prussian army had achieved since the beginning of the war. ${ }^{64}$ The next campaign season opened with the siege of the fortress of Schweidnitz on April 1.

Christian Friedrich Zander described the preparations for the attack on the fortress in his letter of March 27, 1758. He revealed more family connections: "I spoke with cousin Behrens who is still healthy; it is heard every day that we are after Schweidnitz without a further bombardment [and] that the cartridges should all be ready. We often hear very loud firing, [but] we think that we are still relatively safe here." ${ }^{65}$ The Itzenplitz Regiment continued to follow the royal army in early 1758 and participated in Frederick's invasion of Moravia and the Siege of Olmütz. In a letter on April 26, 1758, now lost to us, Christian described the regiment's march into Moravia by way of the Silesian city of Neisse. By the $16^{\text {th }}$ of May, Zander reported that the army stood eight miles from the target of the invasion: the Fortress of Olmütz. Even as he and his comrades invaded Austrian territory, Christian Zander continued to report back to Nitzahn on the state of the regiments and the village comrades who accompanied him. He wrote, "Börnicke greets his wife - he is still healthy, as are all of our known comrades. I don't know where our grenadiers are stationed." ${ }^{, 66}$ This is a demonstration of the way that soldiers tried to update their villages with information from their regiments, even if they had no information. The grenadiers of each regiment were combined with those of another regiment as composite units, meaning that soldiers who had originated in the same canton district would have been separated during wartime.

\footnotetext{
63 Ibid, 68-69.

${ }^{64}$ Schimmel, "Kurze Lebensbeschreibung," 190.

${ }^{65}$ Zander, Fundstücke, 73.

${ }^{66}$ Ibid, 76.
} 
Christian Zander described the population of Moravia in the course of his May 16 letter, noting that "here, the people don't know a word of German. They all speak Hungarian, and they are all old Catholics. When they make a burial, they play trumpets and trombones. Diederich has got a hold of some pipes. ${ }^{, 67}$ Despite the wartime environment of the Prussian army, they appeared fascinated by the local customs of the Moravian people. Schimmel, in his usual curt narrative, simply commented, "everything went very well.." ${ }^{, 68}$ Despite the pleasant interlude, everything was not going very well. The Prussian army was deep in enemy territory, on difficult terrain, and with a force barely sufficient to besiege a major fortress such as Olmütz. The Prussians lost a major convoy of supplies and ammunition to Austrian light troops at Domstadtl, and an Austrian field army under Marshall Daun appeared. ${ }^{69}$ Frederick realized that his army was in intense danger and began a well-planned retreat across Moravia and Bohemia. Returning safely to Prussian territory, the Itzenplitz regiment sat out most of the heavy fighting against the Russian Army during the summer and accompanied their king to Silesia as the year continued into autumn.

In the early morning hours of October 14, 1758, Schimmel and the Zanders became aware of an assault against the Prussian army. The Austrian forces launched an overwhelming surprise attack on the Prussian position. Schimmel recalled hearing the hiss-pop of bullets and rattle of musket fire announcing that an attack was underway. ${ }^{70}$ Becoming alive to the danger of the situation, Frederick II ordered the Itzenplitz regiment against the village of Hochkirch itself, while other regiments began counterattacks to the right of the village. Both Prinz Franz von Braunschweig and Feld-Marschall von Keith led the attack on the village, and both were hit by

\footnotetext{
${ }^{67}$ Ibid, 77.

${ }^{68}$ Schimmel, "Kurze Lebensbeschreibung," 190.

${ }^{69}$ Christopher Duffy, Frederick the Great: A Military Life (London: Routledge \& Kegan Paul, 1985), 159-60.

${ }^{70}$ Schimmel, "Kurze Lebensbeschreibung," 190.
} 
enemy fire. Johann Christian Schimmel found himself unable to describe the battle, saying only, "it was a bad, bad night.",71

The soldiers of the Itzenplitz Regiment formed up for action before the main Austrian attack started, and then divided into platoons to march, a deeper formation. It was while they were in this formation that the men began to be hit by heavy artillery that was firing canister into the flanks of the regiment. Prussian Feldprediger Karl Daniel Küster described the scene:

Field Marshall [Keith] called for his horse, and ordered his General-Adjutant, the excellent Captain von Cocceji, that he wanted the Itzenplitz regiment to come up. This whole excellent regiment came, going into the village courageously with bayonets fixed, but before they could reach the enemy with small-arms fire, they were struck down by enemy cannons planted in the village street, before they had taken two thirds of the village. Only a small remnant of this heroic regiment survived to be pushed back, and these men joined the Kannacker Regiment. ${ }^{72}$

Attacking up the narrow village streets, the Itzenplitz Regiment became a perfect target

for enemy artillery. During this attack, the regiment was also charged by cavalry operating under the overall command of Austrian commander Ersnt Gideon von Loudon. The double threat caused by both the artillery barrage and enemy cavalry caused one historian to comment that "they were partly cut to pieces, partly blown away." ${ }^{, 73}$ Despite this heavy resistance, the troops forced their way into the village and began taking cover in houses and the churchyard. By this time, the regiment numbered only a few hundred men. ${ }^{74}$

Shortly after the battle, the Zanders' family in Nitzahn received the following letter: "Dear Mrs. Schultz and dear boy Wilhelm, I report to you the knowledge that both (Christian)

\footnotetext{
71 Ibid.

${ }^{72}$ Carl Daniel Küster, Des Preussischen Staatsfeldpredigers Küster, Bruchstück Seines Campagnelebens Im Siebenjährigen Kriege ... Nebst Einem Vorbericht Des Königl. Herrn Oberkonsistorialraths Sack. Zweyte ... Stark Vermehrte Ausgabe (Berlin, 1791), 44.

${ }^{73}$ Norbert Robitschek, Hochkirch: Eine Studie (Wien: C. Teufen's Nachfolger, 1905), 68.

${ }^{74}$ Ernst von Barsewisch, Meine Kriegs-Erlebnisse Während Des Siebenjährigen Krieges 1757-1763; Wortgetreuer Abdruck Aus Dem Tagebuche Des Kgl. Preuß. General-Quartiermeister-Lieutenants C.F.R. Von Barsewisch (Berlin: Warnsdorff, 1863), 73.
} 
Friederich and (Johann)Diederich are no longer with us as a result of the skirmish we had near Hochkirch in Saxony. We do not know if they are dead, alive, or prisoners. ${ }^{.75}$ This was the last report on the two Zanders received by their family, and it seems likely that they died on the battlefield, or were wounded and died in captivity. ${ }^{76}$ After the Seven Years War, Frederick II believed that each regiment likely contained only a hundred men who had been with the colors in $1756 .{ }^{77}$ Though perhaps grim, this figure matches the seventy-odd common soldiers who appeared for Prinz Henri's luncheon in 1787. Looked at another way, this estimate indicates that one in eighteen soldiers who served at the start of the war would survive to its end. It is perhaps not surprising that the Zanders died; it is surprising they managed to live as long as they did. Once again, this shows the importance of letters as a supplementary source to memoirs. A tiny fraction of Prussian soldiers served throughout the whole of the Seven Years War, meaning that memoirs of the entire conflict provide a narrow picture of soldiers' experience.

The Battle of Hochkirch was nothing short of a disaster for the Itzenplitz Regiment. In addition to losing $802 \mathrm{men}$, the regiment lost approximately 50 percent of its officers. One of the elite regiments of Frederick II's army had ceased to exist as an effective fighting force. Despite this what is remarkable is not that the Itzenplitz Regiment was wiped out, but that it survived as long as it did. Since the beginning of the war, the regiment had fought in four major battles, usually in the front line, and in the advanced guard at Leuthen. Like the thousands of other native Prussians lost in 1756-1758, the Zanders and their comrades were an irreplaceable loss for Frederick's army.

\section{AFTER HOCHKIRCH}

\footnotetext{
${ }^{75}$ Zander, Fundstücke, 82.

${ }^{76}$ Ibid, 110.

${ }^{77}$ Duffy, The Army of Frederick the Great, 292.
} 
Johann Schimmel survived the shocking night at Hochkirch, but his ordeal was far from over. After Hochkirch, Schimmel next described his experience at the Battle of Maxen in 1759. The two battalions of Itzenplitz did not fight at Maxen, so it is likely that during some point in 1759, Schimmel was transferred to the regiment's combined grenadier battalion. These grenadiers, combined with the grenadiers of the Meyerinck Regiment (IR 26), fought independently from their main regiments. The Itzenplitz Grenadier companies, (GB 13/26), had suffered horrendous casualties at the Battle of Kunersdorf, and it is possible that Schimmel was transferred into the grenadiers to replace that shortfall. This regiment, after already having a disastrous year, was sent on a raid by Frederick II under the command of General Friedrich August von Finck. Finck's forces were surrounded by the Austrians at the Battle of Maxen, on November 20, 1759. Schimmel remembered, "In 1759, I became a prisoner at Maxen. We wept with anger at this, but it did not help. ${ }^{, 78}$ Schimmel was transported to Vienna by way of Prague and reported that "we gave the Empress Maria Theresa joy, at the sight of so many captured Prussian fellows. We were given a cross and some commissary bread." ${ }^{, 79}$ The Austrians then transferred the prisoners to Mantua, then transported them back to Hungary under heavy guard.

At this point, however, Schimmel had a rare turn of luck. The commandant of the fortress where the prisoners were sent was sympathetic to the musicians among the captured Prussian troops, and allowed them to travel into the town in order to earn a wage. Schimmel traveled to the city and sought out an inn. He recalled thinking "This was a good turn for us Oboists!" ${ }^{80} \mathrm{He}$ and his comrades shifted for themselves, and Schimmel found a place as an instructor of music for two daughters of a merchant. He instructed them on the clavier and the violin, and when the

\footnotetext{
${ }^{78}$ Schimmel, "Kurze Lebensbeschreibung," 190.

${ }^{79}$ Ibid, 191.

${ }^{80}$ Ibid.
} 
lessons were over would perform in the city streets for money. It did not take long for Schimmel to convert his teaching employment into something a bit more substantial:

The oldest daughter of the merchant, her name was Therese, said that she liked me. I was a young good looking fellow, and she was quite pretty. You know, one thing leads to another. The girl asked her father day and night if she could marry me, and he finally gave his consent on the condition that I would become Catholic. I didn't like that. I thought, if I sell my soul, I would sell anything! Despite that, the girl was still sweet on me, and she and her father left for the Leipzig trade fair, I talked to her so long that I was able to convince her to give me a suit of Hungarian clothes. I cut my hair, and passed happily out of the city, over the borders, and to Leipzig. I thought to myself, 'You've done that, now to get back to Prussia! ${ }^{11}$

After a brief stay with his aunt in Herzberg, Saxony, Schimmel was returned to the Prussian army via Captain von Puttlitz' recruiting party. The Itzenplitz Regiment would continue to serve in the Seven Years War, but with the death of General Itzenplitz in 1759, the regiment was commanded by Friedrich Wilhelm von Syburg, and became known as the Syburg Regiment. Under this title, it served in the battles at Liegnitz, Hochgiersdorf and Torgau in 1760. During the Battle of Liegnitz, it was stationed on the side of the army that wasn't heavily engaged. At the combat of Hochgiersdorf in September 1760, it served in Major General Zeuner's brigade, and was placed in the vanguard at the Battle of Torgau.

During 1761, the Prussian army experienced near collapse, as officers increasingly became despondent at the military situation. With the loss of the fortress of Schwiednitz on October 1, 1761, it became apparent that Prussia was on the verge of military disaster. The death of Elizabeth Petrovna, the Tsarina of Russia, on January 6, 1762, however, created a situation by which the war could continue. Peter III, Elizabeth's heir, was a German prince more interested in reclaiming his homeland of Schleswig than fighting a war with Prussia. He idolized Frederick as

\footnotetext{
${ }^{81}$ Ibid. 193. This anecdote, while intriguing, might stem from Grimmelshausen's Simpliscius Simplicissimus.
} 
a military hero and did not desire to continue the war with Prussia. Indeed, to reclaim Schleswig properly, he needed Prussia as an ally. Consequently, he withdrew from the French and Austrian alliance and made an alliance with Frederick II. ${ }^{82}$ As a diplomatic nicety associated with the alliance, Frederick II of Prussia gave Tsar Peter III honorary command of one of his regiments, none other than IR 13, Regiment von Syburg, the old Itzenplitz Regiment. Now known as Regiment Kaiser (the German term for Tsar Peter III's title), the regiment fought in the 1762 campaign to free Silesia from Austrian occupation. On July 21, at the Battle of Burkersdorf, the regiment helped a Russian corps pin Austrian troops in place, as Prussian detachments under Generals Neuwied, Möllendorf, and Knobloch dislodged the Austrians from defensive positions on the hills above Leutmannsdorf and Burkersdorf. ${ }^{83}$ The Regiment then participated in the Siege of Schwiednitz, and with the end of the war, formed part of the garrison of the city of Berlin. For the remainder of Frederick's reign following the Seven Years War, the regiment held a special place of honor, being allowed to parade directly behind the Garde Regiment, moving forward from its traditional place in the line. ${ }^{84}$ With the death of Tsar Peter III, the regiment passed into the hands of General Friedrich Wilhelm von Wylich-Lottum until 1774, Colonel Heinrich Gottlob von Braun until 1794, and finally Major General Alexander Wilhelm von Arnim, who commanded the regiment when it was captured by the French in the Prussian disaster and downfall of 1806. The regiment was never re-raised after 1806, ending its military history.

\footnotetext{
${ }^{82}$ Peter H. Wilson, German Armies: War and German Politics, 1648-1806 (London: University College London Press, 1998), 279.

${ }^{83}$ Christopher Duffy, By Force of Arms: The Austrian Army in the Seven Years War, (Chicago, Ill: Emperor Press, 2008), 2:28.

${ }^{84}$ Duffy, The Army of Frederick the Great, 330.
} 
After the war, Schimmel recuperated with his family, but decided that he liked the world of the military better, and was recruited into the hussars by General Belling. ${ }^{85} \mathrm{He}$ remained in the military through the 1790 s, and lost several of his children in the Napoleonic Wars. When interviewed, he was approximately one hundred years old, and still enjoyed playing music. He ended his tale, "if, God knows, there are any red Hussars still alive, just ask them about old Schimmel!" 86 And what happened to our Swiss would-be servant turned soldier? Although Ulrich Bräker escaped from the Prussian army individually, the Austrians grouped him with a number of other Swiss deserters, including his friend, fellow Swiss, and former regimental comrade Bachmann. He recalled, "How we jumped for joy to see each other again so unexpectedly, and in freedom! We began to tell each other our tales and to rejoice as if we were already home and sitting in the chimney-corner." ${ }^{87}$ Bräker, in his joy, described Bachmann in terms of family. For foreigners in Prussian service, forming relationships with groups of men from similar locales provided needed moral support. Eventually, he made his way back to his home village of Wattwil, today in the Wahlkreis of Toggenburg. Bräker was still wearing his uniform and claimed that his appearance was so changed that his family did not recognize him. Bräker continued to wear his uniform, long after he could have sold it. For Bräker, as Jürgen Kloosterhuis has demonstrated, being a soldier in the Prussian army had long benefits and bestowed a different worldview of self-confidence upon the peasants who served. A few days later, Bachmann appeared to collect a debt, and Bräker made him confirm the story of his enlistment, service, and escape.

\footnotetext{
${ }^{85}$ For more information on Belling's Hussars during this period, see: Michael V. Leggiere, Blücher: Scourge of Napoleon, (Norman, University of Oklahoma Press: 2014) 14-21.

${ }^{86}$ Schimmel, "Kurze Lebensbeschreibung,",200.

${ }^{87}$ Bräker, Lebensgeschichte, 153-54.
} 
In a society deeply "interpenetrated" by the military, Prussian common soldiers could demonstrate their military service as a quick way to gain prestige. Both in and out of uniform, they were quick to remind those around them that they had served in a famous army, under a famous prince. Especially after the Seven Years War, military service in the Prussian army made at least some common soldiers proud. Service in the Prussian army became a cultural currency as these soldiers paraded their military service to gain recognition and respect. Native cantonists sought to use their military service to gain permission to build their own cottages and thus become a part of a lower class of freeholding peasants known as Büdnerei (cottagers). Soldiers would petition the government for this right as a reward for their military service. Even without owning farmland, the ability to become head-of-household vastly improved the standing of these former soldiers in village life. The Brandenburgisches Landeshauptarchiv contains hundreds of these petitions from soldiers. ${ }^{88}$

Even soldiers who disliked their time of service, or deserted away from the Prussian army, such as Bräker, were keen to remind their friends and family of their time in the service. Whether in an attempt to gain recognition, or simply by habit from military life, Bräker rose early on Sunday morning to clean his uniform "as I had for church parade in Berlin." If Bräker were trying to attract attention to himself it certainly worked: at church he found that "my friends greeted me warmly, []and everyone else gawked at me as though I was Turkish." ${ }^{89}$ Specifically, he managed to impress his old girlfriend, Anne, who had subsequently married Bräker's cousin during his absence. The former member of the Itzenplitz Regiment took no little delight in the fact that when she saw him in uniform, "she stared at me flirtatiously, without blushing. In my

\footnotetext{
${ }^{88}$ For a representative example of this type of petition, see, BLHA Rep. 2D, Rep 2 Kurmarkischer Kammer, Nr. 15944. For a complete list of this type of petition, see Jürgen Kloosterhuis, Militär und Gesellschaft in PreußenQuellen zur Militärsozialisation, 1713-1806, 3 Volumes, (Frankfurt: Peter Lang, 2014).

${ }^{89}$ Bräker, Lebensgeschichte 164, 165.
} 
turn, I greeted her coolly, with a knowing smile." ${ }^{90}$ Bräker was not afraid to appear the dashing soldier when it suited him. Bräker's narrative demonstrates the cultural currency one could earn by returning in uniform to one's village community.

\section{CONCLUSION}

Men like Johann Schimmel and Ulrich Bräker moved fluidly between military and civilian worlds, and viewed military status as an advantage in civilian circles, not as a marker of a separate and hostile identity. The Zanders, like the other Prussian soldiers we have met so far, attempted to remain connected to their family and village community during their far-ranging military service. All of these groups of soldiers attempted to form communities within the army: both Schimmel and Bräker displayed a preference for comrades from their previous states (the Swiss Confedreration and Saxony) while the workings of the canton system provided a readymade community for the Zanders. In the Itzenplitz Regiment, these common soldiers had experiences as diverse as writing frequent letters home to family, being involved in fierce battles, playing music for urban Hungarians, deserting from the Prussian Army, escaping back to the Prussian army, and being honored by the brother of their king in a banquet for service long remembered. As these men negotiated their lives in and around the army, regimental identity and local communities played a vital role in their diverse experiences, and enabled them to bear, and sometimes survive, their military service.

\footnotetext{
${ }^{90}$ Ibid.
} 


\section{Cumberland, Conway, and Prussia: Long-Term Causes of the Army Reforms of 1782}

On November 28, 1780, parliament held a debate in the House of Commons in order to address the lack of resources for subduing the American rebellion. Several well-known figures in the American War of Independence era, including General John Burgoyne and Lord North, participated in this debate. Beginning with a scheme to vote more money for naval recruitment, the discussion swiftly turned to the lack of money for the army. Parliament discussed how best to support the British Army in the long and unsuccessful war with the North American colonies. After a speech from the Secretary at War, Charles Jenkinson, and the man who would be his successor, Thomas Townsend, John Burgoyne and Lord North asked whether it was more effective to raise new regiments, or send new recruits to older, more senior regiments.

At this point, Lt. General Sir George Howard, an officer with experience in the War of Austrian Succession and Seven Years War, rose to make a speech related to infantry recruitment. Howard began by emphasizing the local nature of regimental loyalty in the counties of England. Howard recalled that he had formerly been the colonel-proprietor of "an Old Regiment of foot, which was always recruited out of Somersetshire, and never tried for recruits elsewhere. Another regiment...was called the Yorkshire regiment and always recruited in that county."1 Howard argued that a system of local recruitment was not a new idea; it had been proposed by the Duke of Cumberland in the 1740s. Howard recalled that he had had a conversation with the Duke of Cumberland: "The Duke's idea was that each county should have one or more regiments of its own, such as the Middlesex regiment, the Essex regiment, and the Surrey regiment, \&c. \&c. the

\footnotetext{
${ }^{1}$ Anonymous, The Parliamentary Register or History of the Proceedings and Debates of the House of Commons, (London: J. Almon, 1780) 1:193.
} 
men not to be enlisted for life, but during a war, or at other times for a limited period."2 Furthermore, the Duke advocated that the men should be recruited at the county level: "when recruits were wanted, that a requisition should be made to the county session to furnish them."3 The Duke of Cumberland's ideas, in part, inspired the British Army Reforms of 1782.

In exploring the army reforms of 1782, this chapter draws extensively on the British National Archives, the collections of the Templer Study Centre at the National Army Museum, as well as the Royal Archives at Windsor. In doing so, it makes connections which previous historians have missed in their explorations of the reforms. This final chapter explores the way in which, fifteen years after his death, ideas originally sponsored and put forth by the Duke of Cumberland influenced the creation of the Army Reforms of 1782. Furthermore, it argues that Prussian practices influenced the Duke of Cumberland's thinking. In an effort to encourage greater local identity among the regiments of the British Army during a time of military failure, officers of the British Army drew on the experience of the former royal commander in chief, who had been in turn inspired by his observations of the Prussian Army. In the final analysis, the Army Reform Act of 1782 may not have been an administrative success, but its plan of execution was developed by men who had been inspired by the Duke of Cumberland, and by their observations of the Prussian military. Thus, the Army Reform Act of 1782 demonstrates that some British officers valued the local connections to place exhibited by their men, and related these connections to Prussian military experience and practice. These observations demonstrate further how soldiers in eighteenth-century armies experienced a world that was simultaneously local and transnational. In 1782, British soldiers saw an increased effort on the part of elites to incorporate their local identities formally as part of the military structure.

\footnotetext{
2 Ibid, 194.

${ }^{3}$ Ibid.
} 
After addressing the current state of research on the reforms, this chapter will discuss the immediate origins of the reforms and the influence of the man most directly involved in influencing their creation: William Augustus, the Duke of Cumberland. Following an examination of Cumberland's ideas with regard to recruitment, the chapter will turn to his ideas on Prussia, and the potential Prussian influence on the man who directly oversaw the army reforms: William Seymour Conway. Finally, the chapter will assess the response of the ColonelProprietors to the reforms, and the reforms' legacy. The scholarly literature dealing with the 1782 Army Reforms focuses more on the legacy of the reforms, rather than the reforms themselves. The Army Reforms of 1782 have generally been dismissed by historians as an ineffective half-step in creating local identities within regiments, which was not completed until the Childers Reforms of the 1880s. ${ }^{4}$ John Pimlott, G.H. Cleare, and Stephen King have all explored the reforms in some detail. ${ }^{5}$ In his 1975 dissertation, Pimlott argued that the reforms were a failure based on a 1783 mutiny, which Stephen King has subsequently disproved with evidence from the British National Archives. ${ }^{6}$ By and large, this chapter agrees with the assertions made by King regarding the reforms, but seeks to explain and further clarify several claims which King made about the reforms, but did not back up with archival evidence. Repeatedly, King cites secondary sources which suggest that Cumberland may have been an early advocate for such a reform, but never definitively connects the Duke of Cumberland with efforts regarding localized recruitment in the British Army during the eighteenth century. Finally, this chapter demonstrates that Prussian practice informed Cumberland's ideas. This

\footnotetext{
${ }^{4}$ For a prime example of this kind, see: David French, Military Identities: The Regimental System, the British Army, and the British People, 1870-2000, (New York: Oxford University Press, 2008) 10-11.

${ }^{5}$ G.H. Cleare, "County Names for the regiments in 1782," Journal of the Society for Army Historical Research, Vol. 36, No. 145 (March 1958) 34-38; John L. Pimlott, "The Administration of the British Army, 1783-1793" (unpublished doctoral thesis, Leicester University, 1975) 2; Stephen King, 'The 1782 British Army Reforms: Adoption of County Titles', (unpublished master's thesis, University of Plymouth, 2011).

${ }^{6}$ King, 'The 1782 British Army Reforms', 2
} 
chapter is the first study that looks beyond national history for transnational inspirations of the 1782 reform. Earlier historiography focused solely on Britain, and not on broader perspectives furnished by comparisons with other eighteenth-century armies.

The chapter tracks changes in elite perceptions of common soldiers in England that were expressed before the French Revolution. John Lynn has asserted that the French Revolutionary era marked a watershed in military motivation, an assertion which Ilya Berkovich has recently challenged. In the eighteenth century, I argue, officers did not simply think of their soldiers as the dregs of society, but rather sought to create and sustain ties between their army and the civilian society that supported it. British military planners wanted to draw on ties between family, locality, and the army, in a way which mirrored the situation in Prussia as seen in the last chapter. These plans, though occurring in the 1780s, reached back to ideas circulated by the Duke of Cumberland in between the War of Austrian Succession and the Seven Years War.

\section{THE BRITISH ARMY AND DEFEAT IN THE EIGHTEENTH CENTURY}

Seventeen years after HRH the Duke of Cumberland's death, the debate about recruitment in Britain finally came to a head. During the American War of Independence, the British Empire faced its greatest crisis since the Seven Years War, particularly after the European powers of France, Spain, and the United Provinces joined in an alliance with the rebelling American colonists after 1777. The reasons for British defeat have been explored at length by historians who point to a lack of strategic planning, logistical problems, and the limitations of state power in the eighteenth century. ${ }^{7}$ Matthew Spring has demonstrated that the

\footnotetext{
${ }^{7}$ Piers Mackesy, The War for America, 1775-1783, (Lincoln, University of Nebraska Press, 1964) Andrew J. O'Shaunessy, The Men who Lost America: British Leadership, the American Revolution, and the Fate of Empire, (New York: Yale University Press, 2014); Arthur Bowler, Logistics and the Failure of the British Army in America, 1775-1783, (Princeton: Princeton University Press, 1975) Fred Anderson, Crucible of War: The Seven Years War and the Fate of Empire in British North America, 1754-1766 (New York: Alfred A Knopf, 2000).
} 
British Army was tactically effective, but that this tactical success did not always translate into strategic or operational success. ${ }^{8}$ As Stephen King has shown, however, British contemporaries primarily viewed their defeat as a result of a lack of manpower in America. ${ }^{9}$ Comparing the relative strength of contending forces during the British Army's defeats in the American War, particularly at Bemis Heights and Cowpens, and even some victories like Freeman's Farm, Guilford Courthouse, and Eutaw Springs demonstrates that in terms of absolute numbers, the British Army was fighting at a clear disadvantage. ${ }^{10}$ The British Army stared down defeat in the American War of Independence, and responded by considering a serious change in its recruitment policies.

The regiments of the British Army recruited men via roving recruiting parties that wandered throughout the islands, or stayed close to a particular place, based upon the preference of the officer in command of the party. This system of recruitment was utilized, in some form or other, by almost all of the major European military powers during the eighteenth century. Some armies, such as the Prussian and Russian armies, supplemented their forces via forced enrollment, but most states recruited men voluntarily. Christopher Duffy has asserted that during the eighteenth century, European militaries recruited more men via voluntary enlistment than any other means, and he is quite correct in this observation. ${ }^{11}$ Particularly during wartime, however, voluntary recruiting had its limits; as a result, states felt the need to take drastic measures. At the close of the American War of Independence, the British military was desperately short on

\footnotetext{
${ }^{8}$ Matthew Spring, With Zeal and With Bayonets Only: The British Army on Campaign in North America, 1775 1783, (Norman: University of Oklahoma Press, 2008) 263-281.

${ }^{9}$ Stephen King, "The 1782 Army Reforms: The Adoption of County Titles", 20.

${ }^{10}$ For estimates of numbers at these battles, see, Lawrence Babits, A Devil of Whipping: The Battle of Cowpens, (Chapel Hill, University of North Carolina Press, 2001) Lawrence Babits et al, Long, Obstinate and Bloody: The Battle of Guilford Courthouse, (Chapel Hill, University of North Carolina Press, 2009); Irene Boland et al, Eutaw Springs: The Final Battle of the American Revolution's Southern Campaign (Columbia: University of South Carolina Press, 2017).

${ }^{11}$ Christopher Duffy, Military Experience in the Age of Reason, (New York: Atheneum, 1988) 89.
} 
manpower. Initially fighting a war that was deeply unpopular with the British public, the Army was forced by 1778 to rely on impressments as a form of recruitment. Numerous small regiments sprang up, raised by noblemen as volunteers, but this was not enough to balance the shortfall in manpower. In short, military defeat played a large role as an immediate cause of the reforms. Over thirty years earlier, a similar process had taken place.

With the exception of the celebrated Battle of Dettingen and success against the Jacobite rebels at Culloden, the British Army found very little success in the War of Austrian Succession (1739-1748). Facing the highly skillful Marshal de Saxe in the service of Louis XV, British forces were defeated at the large field battles of Fontenoy, Rocoux, and Lauffeld. During the years from 1744-48, French forces occupied much of the United Provinces. By the time diplomats ended the fighting, a significant Russian force was very close to the theater of operations, yet De Saxe and the French had achieved close to a total victory in eighteenthcentury terms. British forces in the Low Countries only ever made up a portion of larger allied armies between 1743 and 1748, and these coalition armies were severely outnumbered by the French in the later stages of the campaign: by 40,000 men at Rocoux and 20,000 at Lauffeld. As a result, the British commander in chief, Cumberland, turned his attention to new schemes of recruiting more forces into the British Army, in order both to safeguard the defense of the British Isles and project more force abroad.

\section{CUMBERLAND AND CONWAY'S PROPOSED REFORMS}

Compared with other British military commanders of the 1739-89 era, such as John Forbes or Charles Cornwallis, scholars have written less on the Duke of Cumberland. Cumberland's historical legacy has been dominated by debates regarding the level of relative 
brutality in the Jacobite repression after the 1745 uprising. ${ }^{12}$ There is little doubt that Cumberland's troops committed excesses after the Battle of Culloden, but the 11,000 soldiers deployed to occupy Scotland after 1745 meant that Scotland was still one of the least militarized locales in Europe. Of course, the consequences to the highland way of life and suffering of highland people between 1740 and 1900 was enormous, but little violence of far-reaching significance was committed by British troops under Cumberland's direction between 1745 and 1755. ${ }^{13}$ Rather, between 1748 and 1756, Cumberland's main activity was related to a series of attempts to reform the British Army in a multitude of ways. Most of these reforms were connected to making the British officer corps more professional; for example, the elimination of the practice of the sale of commissions was one of Cumberland's goals. Cumberland also attempted to change, on a fundamental level, the way the British Army was recruited. In doing so, he began to circulate new strategies, some of which would be incorporated in Army Reforms of 1782 .

Cumberland's first serious plan to reform the army was drawn up in 1749, although the exact date is unclear. ${ }^{14}$ His Royal Highness had time, with the end of the War of Austrian Succession, to begin seriously planning a major reform of the British Army. Cumberland's initial plan called for a number of alterations, including changes to how the Regimental Agents kept their non-effective accounts, and when specific musters and inspections would take place. Most importantly, however, Cumberland called for a serious overhaul of the way British Regiments recruited their soldiers. He began by demanding that "the regiments be made provincial, and

\footnotetext{
${ }^{12}$ For an example of this type of literature, see: Jonathan Oates, Sweet William or the Butcher? The Duke of Cumberland and the '45, (London: Pen and Sword Military, 2008).

${ }^{13}$ Thomas Devine, The Scottish Clearances: A History of the Dispossessed, 1600-1900, (London: Allen Lane, 2018) 45

${ }^{14}$ Royal Archives (RA) Cumberland Papers (CP) /MAIN/43 f.14b
} 
three months' notice given from the respective counties to the regiments of their name, to find so many men, of such description, on such a day and at such a place."15 General officers would then review the recruits, perhaps once or twice a year, and the commander of each company, a captain, would receive monetary payments for having complete numbers of men in their commands. By advocating for this policy, Cumberland was pushing for a revolutionary change that would fundamentally alter the way in which the army was recruited, with respect to both the method of recruitment and its impact on local communities. Cumberland's plan called for the conscription of subjects in particular counties by particular regiments of foot. It is important to note that Cumberland knew that the plan was revolutionary in nature. A careful planner, Cumberland wrote hypothetical objections to each part of his project. Under the section containing conscription, he insightfully noted, "A new tax on the people, will cause many disputes, too great an innovation." ${ }^{16}$ Cumberland believed that the best way to secure England was to introduce a system of county-level conscription, but also realized that such a move would cause intense unrest in British politics, and indeed, among the British population.

This proposed innovation also clearly shows the Prussian influence present in Cumberland's circles after the War of Austrian Succession. The Prussian Army was not the only army to recruit men locally in the eighteenth century. The French, Russian, and Swedish armies all utilized localized recruitment, many within a longstanding tradition. ${ }^{17}$ The French army named many of their regiments according to region, based on unit recruitment, in some cases

\footnotetext{
${ }^{15}$ Ibid, f14a.

${ }^{16}$ Ibid.

${ }^{17}$ For the Swedish system, see: Janne Backlund, 'Rusthållarna i Fellingsbro 1684-1748 : indelningsverket och den sociala differentieringen av det svenska agrarsamhället' (unpublished doctoral dissertation, University of Uppsala, 1993); For the French system, see: Julia Osman, 'The Citizen Army of Old Regime France', (unpublished doctoral dissertation, University of North Carolina-Chapel Hill, 2010); For the Russian system, see: Christopher Duffy, Russia's Military Way to the West: Origins and Nature of Russian Military Power, 1700-1800, (Routledge: London, 1981) 125-129.
} 
stretching back all the way to the 1580s. Although newer French regiments were often named for their proprietor, older regiments retained their regional titles. In Russia, soldiers rebuilt their village communities through the Артель, or artel. These groups of soldiers elected their leadership, and according to a group of scholars, replicated the village life, or сходка of their local communities within their regiments. ${ }^{18}$ Russians entered service, in most cases, for life. Many Russian villages conducted quasi-funerals for their recruits. ${ }^{19}$ As a result, there was little contact with former village communities. The artel network helped ease this burden on the soldiers. Like other European armies, then, it is unsurprising that the Prussian army contained a large degree of loyalty to place and family. Also, like many of the other continental armies, the Prussian military of the eighteenth century also attempted to reinforce its men with a sense of loyalty to their regiments.

Despite this, evidence suggests that Prussia, rather than these other states, influenced Cumberland's thinking. The Duke traveled through the Prussian western provinces in the aftermath of the war, and never made comparable travels in France, Sweden, or Russia. As a commander in chief whose primary aim was to improve the performance of the British Army, Cumberland looked far afield for possible innovations and ideas. His papers between 1749 and 1756 show a clear interest in Prussian and Russian military affairs but he wrote more developed thoughts on the Prussian Army. ${ }^{20}$ Cumberland set out to analyze the success of the Prussian

\footnotetext{
${ }^{18}$ John Bushnell, "Peasants in Uniform: The Tsarist Army as a Peasant Society," Journal of Social History 13, no. 4 (1980); John L. H. Keep, Soldiers of the Tsar: Army and Society in Russia 1462 - 1874 (Oxford: Clarendon Press, 1985); Elise Kimerling Wirtschafter, From Serf to Russian Soldier (Princeton: Princeton University Press, 1990).

${ }^{19}$ Christopher Duffy, Russia's Military Way, 129.

${ }^{20}$ RA CP/MAIN: Main Series Vol. 67: X 31.16; RA CP/MAIN: Main Series Vol. 43: 1-5
} 
military in 1754, penning a document entitled "Observations on the Prussian Discipline."21 Cumberland opens this document by asserting:

The Prussian discipline has acquired such a degree of reputation that it is to be hoped that an attempt to trace its principles, and examine the grounds on which it is built, will not be thought presumptive in one whose station calls him particularly to attend such subjects. Tis this which has given rise to the following observations on the proper method of disposing a battalion for firing and the exercise, requisite thereto, which are drawn from that [Prussian] discipline, and may perhaps be useful in ours. ${ }^{22}$

Cumberland is very cautious in his language. The political backlash against his army reforms was significant, and he couched his observations in very neutral terms. Most of his observations deal with tactical maneuvers that need not detain us here, but the document conclusively proves that Cumberland looked at the military system of Prussia, and thought seriously about incorporating the best features of those other states in the British system. Many British officers were influenced by Prussian tactics, but Cumberland's writings show another aspect to this influence as well. Returning to the army reform plan of 1749, two key features of the plan give serious indications of Prussian influence: first, Cumberland's plan to associate administrative units within the army with local geographic units in England (counties, rather than Canton districts as in Prussia) and second, Cumberland's plan to use those geographic areas to draw recruits via conscription to specific regiments. While the first part of the proposed reforms could indicate the influence of any particular number of armies, such as the French, for example, the second indicates without question that in this specific instance Cumberland was influenced primarily by the system of recruitment in Prussia. Christopher Duffy has referred to the fad for Prussian military fashion which arose after the Seven Years War as "Prussomania," but

\footnotetext{
${ }^{21}$ RA CP/MAIN: Main Series Vol. 67: X 31.16

${ }^{22}$ Ibid.
} 
Cumberland papers reveal something more than a surface level desire to copy the Prussian style of uniforms. Rather, he seriously considered the basis of the Prussian system, and attempted to adopt portions of it in Britain. Thus, as early as 1749, William Augustus, the Duke of Cumberland, was attempting to reform the system of recruitment in England along more Prussian lines.

Cumberland was aware of the obvious resistance that this move would cause, as his section listing potential objections indicates. In his speech to Parliament on November 28, 1780, Lt. General Sir George Howard also indicated that Cumberland used him as a sounding board for potential objections to this type of plan. Howard indicated that during these conversations he had told Cumberland, "such a law would partake of the nature of an impress act in its operation, and therefore would be objected to, but his 'Royal Highness had convinced him of its equity and practicability." ${ }^{23}$ Although it is impossible to ascertain exactly when this conversation between Cumberland and Howard took place, it is likely that they had the opportunity to converse during and after the War of Austrian Succession. During this period, Cumberland frequently commanded forces where Howard served as a subordinate commander. During this period, Howard was a Lt. Colonel, and it is unlikely that he was the only officer with whom Cumberland shared his plans. Howard's objections and the objections of other officers of similar status likely played a role in stopping Cumberland from bringing his ideas into the realm of public debate. This had already occurred once in 1750, when a fearful parliament believed that Cumberland would use the Mutiny Act to seize power as a military dictator. The uproar over the Mutiny Act had badly marred his reputation, and likely prevented his army reform plan of 1749 from seeing the light of day.

${ }^{23}$ Anonymous, The Parliamentary Register, 194. 
The failure of his plan of 1749 did not prevent Cumberland from continuing to develop plans for the reformation of the British Army. With the outbreak of the Seven Years War in 1756, Cumberland drew up a second, much lengthier and more detailed plan than his first. Having firsthand knowledge of the power of an angry parliament, the first article in this new plan, entitled "Scheme for Empowering H.M. to raise men for the Land Forces," specifically addresses the power of Parliament. It begins, "That his majesty may be empowered, from time to time, during the present war, to raise any number of men not exceeding $30,000 \ldots$ voted by parliament for such year respectively." ${ }^{24}$ Clearly, this first article explicitly uses language which places Parliament, and not the king, as the supreme authority, which shows that Cumberland had indeed learned from his experiences with the Mutiny Act in 1750. In the second article, the scheme outlines the mechanisms for recruiting men. Cumberland continued, "That each County and Riding in England and Wales shall furnish men in the same proportion as appointment in the Militia Bill in the last session." ${ }^{25}$ This sentence is truly remarkable. Cumberland indicates that the forces should be raised locally, drawing on county and local communities, as was indicated in his 1749 plan. His continued belief in the power of conscription is present, but carefully veiled. He proposes that the respective localities should "furnish men," but also powerfully defends the way of doing so by bringing in comparison to the Militia Bill, which Parliament had already approved. In essence, Cumberland argued that if parliament approved conscripting men for the Militia, and had already approved such a plan, could they really oppose raising men for the regular forces in time of war? The second article of the "Scheme" refers to Parliament being repeatedly consulted, and that a bill would be required to approve this recruitment plan each year it was required. This language demonstrates Cumberland's abilities, not simply as an army

\footnotetext{
${ }^{24}$ RA CP MAIN/59 f.165

${ }^{25}$ Ibid.
} 
reformer, but as someone with a keen sense of parliamentary politics. Cumberland, far from desiring to use the army as a weapon against parliament, was concerned enough for the defense of England to place all the necessary power for recruiting large numbers of men in the hands of Parliament.

Articles three through seven of this plan outline implementation on the local level. They address the requirements it places on the Lord Lieutenant of each county down to the number of days between the receipt of the conscription notice that county officers were required to meet and discuss the lottery system for selecting eligible men. In broad strokes, the conscription order would originate with the Secretary of War and then be distributed to the various County Lord Lieutenants, who would assemble commissioners to implement the conscription. Cumberland specified that the quota for each county should be in proportion to its Land Tax. The receiver general of the Land Tax and the conscription commissioners would then notify the "parochial officers" of each county of the number of men required, and that these parochial officers would be responsible for posting notice on the doors of the parish churches in their districts of a meeting to be held within ten days. Men of a particular tax status would be required to come to the meeting. Those householders meeting the status requirement would elect which local men should be required for the regular army "by majority of voices, or by lot or ballot." 26 Cumberland's details in constructing the workings of this plan are impressive. Having been initially empowered by parliament, the system places responsibility for the process at every level of society, down to the men voting for which of their neighbors should be conscripted into the army. Though it relies on government authority and property requirements at every step the system is surprisingly open to democratic processes. This demonstrates that the Duke of

\footnotetext{
${ }^{26}$ RA CP MAIN/59 f.165c
} 
Cumberland was learning and attempting to mesh his vision for a Prussian-style recruitment system with what was possible in Britain.

Articles eight and nine outline the various requirements for making men eligible to be conscripted by the vote of their neighbors. Article eight indicates that Freeholders, those possessing a vote for members of Parliament, married men with at least one child who were responsible family men and did not draw on public funds, or anyone who was paying more than five pounds per year in rent were not required to serve. This might seem as though it was a way of conscripting the worst elements of society into the army. Most men who served in the British military during the eighteenth century were out-of-work weavers and laborers who possessed some trade but as a result of economic circumstances took on military service. This plan seems to have targeted just that sort of person in creating these requirements. Article nine sets out health, age, and size requirements for selecting conscripts. Interestingly, Cumberland left the age and size requirements blank, perhaps indicating that the plan was still a work in progress, or that he desired to be intentionally flexible year to year in the types of recruits selected.

Articles ten and eleven lay out the process of "seizing" conscripts, which is perhaps a telling choice of words with regards to their perceived willingness to serve. The men were to be rounded up and delivered to a centralized location; anyone who fled was eligible to be charged with deserting from His Majesty's forces. Article twelve discusses at length the process by which conscripted men could appeal their conscription if they believed they were not eligible for selection. If judicial authorities found in the unwilling conscript's favor, the conscript was then required to select his replacement. Article thirteen provided a loophole for men of sufficient means to avoid serving. It stipulated that men who were able to pay the commissioners ten pounds or provide an immediate replacement were not required to serve. The replacement would 
be enlisted as a voluntary recruit, not a conscript, and any money derived from payments to avoid service would be put towards the cost of recruiting further men. Articles fourteen to twenty discuss the consequences of civil authorities failing to comply with the proposed plan. Article twenty-one, a key difference from his Prussian model, makes it clear that this is purely a wartime service measure. Cumberland notes that "no person enlisted by virtue of this act shall be liable to serve longer than six months after the conclusion of a peace."27 This proposed scheme demonstrates that Cumberland was not static in his thinking, but rather attempted to mesh what he found attractive in the Prussian recruitment system with the English aversion to a standing army. Retaining the principle of conscription at the county level, he attempted to incorporate parliamentary authority, as well as local voting, in order to convince the people of England that this was not "too great an innovation," as he had described his recruitment plan of 1749.

Not content simply to reform the recruitment of the army, Cumberland also drew up a system for improving the militia in August of 1756. The plan called for the "raising and disciplining of 32,000 native militia and 1,000 hussars... without compulsion... to reside in the several counties of England, etc, and to be under the direction of His Majesty, His heirs, and successors. ${ }^{28}$ In this scheme, Cumberland abandons his idea of conscription for a militia, but firmly attaches the militia to particular counties. As far as the organization was concerned, Cumberland desired the men "to be formed into regiments and to be called the British Royal Volunteer Militia, and to have the same uniform and clothes once every seven years or as shall be thought proper, all of their arms and clothes to be numbered and marked, and the names of the counties they belong to put on them. ${ }^{, 29}$ Cumberland also included plans for significant financial

\footnotetext{
${ }^{27}$ RA CP MAIN $/ 59$ f. $165 \mathrm{~g}$

${ }^{28}$ RA CP/MAIN/47 f.237

${ }^{29}$ Ibid.
} 
rewards for service in this militia, as well as slightly less harsh punishments than in the regular army:

The punishment for deserters, instead of shooting those absent on duty... for the first offence... they shall forfeit the greatest two days pay... for the second offense... they shall forfeit all four of the last days pay... for the third offense they shall be advertised as deserters, and when taken committed to hard labor for one month, whipped, and then transported to one of his majesty's colonies to serve as a soldier for life. ${ }^{30}$

Significantly, the plan also includes provisions for soldiers in the regular army to receive a discharge and continue to draw pay while serving in this militia. ${ }^{31}$ Like the army, it would be impossible for avowed Catholics to serve in this force. Taken together, these plans represent Cumberland's thinking with regards to defending England from a potential French or Jacobite invasion during time of war, estimating that it would take roughly 30,000 men to safeguard England in addition to regular forces.

Another officer, General Henry Seymour Conway, submitted a plan for recruitment for militia to Cumberland in January 1757. Conway, who had joined the army as a dragoon officer in 1737, quickly rose to prominence, serving as a staff officer with both Marshall Wade and Cumberland himself. He had a prominent military career during the War of Austrian Succession, serving at every major battle in which the Duke of Cumberland took part: Dettingen, Fontenoy, Culloden, and Lauffeld. His temporary disgrace during the Seven Years War and opposition to the fighting during the American War of Independence prevented him from exercising high command during those wars, but proved politically expedient at the end of the American War of Independence, when the second Rockingham ministry rewarded him with the position of

\footnotetext{
${ }^{30}$ Ibid.

${ }^{31}$ RA CP/MAIN/47 f.238
} 
Commander in Chief in 1782. In 1757, however, with all that in the future, he submitted a draft of a plan for recruitment to his Commander in Chief and mentor, the Duke of Cumberland.

Like Cumberland's original plan of 1749, Conway's plan called for raising troops from specific places. Showing a firm understanding of the three-tiered military system of regular forces, volunteers/provincials, and militia, Conway drew up plans for militia and volunteer recruitment. Unlike Cumberland, he argued that "the principal towns of Great Britain should raise one or more battalions, each in proportion to their inhabitants. ${ }^{32}$ Like both of Cumberland's 1756 plans, Conway believed that this scheme, perhaps calling on sixty towns to furnish local battalions, could quickly raise 30,000 men. Also like Cumberland's 1756 plan, it called for the heavy involvement of the Lord Lieutenants of each county, who would appoint the principal officers, drawn from the nobility local to the towns. ${ }^{33}$ In order to train this militia force, a number of corporals and sergeants would be drawn from the regular army. They would exercise this militia "frequently." ${ }^{34}$ Like Cumberland's militia plan, Conway specifically referred to a crisis such as "times of actual invasion or rebellion" as being the militia's reason for being and argued that they should be allowed to reside in their local counties except during these emergencies. Conway also outlined benefits for this force, such as the chance to become pensioners of the Chelsea Hospital, or for widows to draw a pension or life, which might have made it attractive to men forced to take part.

The second part of this document contains a different plan, not for the raising of a militia, but for the raising of what Conway called "Volunteers." Troops like this had been used by the Duke of Cumberland during the Jacobite emergency of 1745, and wore blue coats, unlike the red

\footnotetext{
${ }^{32}$ RA CP/MAIN/49 f.1

${ }^{33}$ Ibid.

${ }^{34}$ RA CP/MAIN/49 f.1a
} 
clothing of the permanent standing army. These troops were viewed as a force sharing qualities with both the militia and regular army. Like Conway's militia plan, this called for the raising of county-based regiments of volunteers, again using large towns as the principle way of recruiting this force. Once again, the number of men recruited was supposed to approach 30,000. These men would be "engaged in time of war, rebellion, or public danger, to appear at times and places that shall be ordered by His M[ajesty] or the Lord Lieutenants of Counties. ${ }^{„ 35}$ Like the militia, these volunteers would not be required to go on foreign service, nor would they be required to service concurrently for more than three years except in time of emergency. In order to be enlisted in the volunteer service, a man needed to be between the ages of sixteen and forty, and over five feet four inches in height. As in his militia plan, these men could access the benefits of the Chelsea Hospital, but were subject to the same punishments for desertion as men in the regular army. Conway concludes both plans with a note to Cumberland encouraging him to recruit men in the regular army for a set term of years, just as in his plan for volunteers. ${ }^{36}$

The outbreak of the Seven Years War in Europe prevented Cumberland from realizing these plans. Though he had previously directed operations in North America in his role as Commander in Chief, after 1756 Cumberland was called back to the continent to serve as the commanding general of the forces opposing the French in Hanover. With his forces narrowly defeated and then badly routed at the Battle of Hastenbeck on July 26, 1757, Cumberland was forced to negotiate with the French, sign the humiliating convention of Klosterzeven, and then retire from public life upon his return to England. After the death of his father in 1760, Cumberland played an important role in advising his nephew, King George III, and played a significant role in the rise of the first Rockingham ministry. Conway, who likewise fell into

\footnotetext{
${ }^{35}$ RA CP/MAIN/49 f.1c

${ }^{36}$ Ibid.
} 
disgrace as a result of his failure in the 1757 Rochefort campaign, also returned to favor with the coronation of the new king. Cumberland died in 1765 at age forty-four, after experiencing health problems from complications of his wound at the Battle of Dettingen and many years of obesity. However, his influence lived on in the careers of army officers he interacted with, and eventually bore fruit in the 1782 army reforms.

A number of key British Army officers involved in the 1782 Army Reform had ties Cumberland, to Prussia, or both. The man who submitted the militia plan to Cumberland, Henry Seymour Conway, took an extensive military tour of the continent in the year 1774. David Scott, a civilian in General Conway's party, took extensive notes on the workings of the canton system. $^{37}$ Though interested in the whole of 'military Europe,' General Conway's party spent more time in Prussia than any other state during their extensive continental tour. The Adjutant General, Sir William Fawcett, had shown an extensive interest in Prussian military doctrine since the 1750s, and had translated numerous works on the Prussian Army of Frederick II. The Deputy-Adjutant General, Adam Williamson, was the only officer in this group who served in America, rather than in Germany during the Seven Years War. Finally, Sir George Howard, who mentioned the idea for the first time in Parliament (in 1780) since the Seven Years War, was an officer under the command of the Duke of Cumberland and had served in the Holy Roman Empire during the Seven Years War. All of these military leaders had an understanding of the functioning of the Prussian Army, putting them in the position to continue, support, and refine Cumberland's initial plans.

${ }^{37}$ Bodleian Library, MS Eng. Hist. c 282, 52-57. 


\section{THE EXECUTION OF THE REFORMS}

By the end of the American War of Independence, Britain needed additional men for its army. After assuming the office of Commander in Chief in March 1782, Conway turned his attention to facilitating the army reforms which he and Cumberland had first proposed over thirty years prior. In their final form, the reforms fell short of Cumberland's twin goal of regimental localization paired with draft recruitment and instead focused purely on tying regiments to place. The military administration hoped that the localization of recruitment would increase the total numbers of recruits but fell short of Cumberland's goal of conscription. On the eve of the 1782 Army Reform, there was undoubtedly a sense of local identity in some regiments, which the reforms attempted to formalize and facilitate. British army officers and civilian administrators cooperated to improve relations between the army and the British public at a local level for a variety of reasons. This was made clear in correspondence between the War Office and Lt. Colonel Irving of the $47^{\text {th }}$ Regiment of Foot. On May 4, 1782, the War Office wrote Irving, replying to a recent report. This letter indicated that the Secretary at War would "take great pleasure in hearing of the good disposition of the corporation and inhabitants of Lancaster towards the $47^{\text {th }}$ Regiment, and of the quiet behavior of the officers and men of the Regiment while quartered in that town." ${ }^{38}$ Officers and administrators preferred when good relations existed between groups of soldiers and civilians of the same state.

Lt. Colonel Irving gave a good sense of the pre-existing local connections (such as they were) between particular regiments and counties in the British Army in his reply to Deputy Adjutant General Williamson on May 19, 1782. Though he was only the Lt. Colonel, he knew that "Sir Guy Carleton [the current Colonel-Proprietor] wished that the recruiting parties might

\footnotetext{
${ }^{38}$ TNA, WO 40/1/110
} 
be sent to Lancashire and the neighborhood of it, where we had constantly been accustomed to recruit, and [Carleton] expressed his desire to consider it entirely a county regiment, and on Lord Amherst offering a quarter for the regiment chose Lancaster." ${ }^{39}$ This shows that clearly, some Colonel-Proprietors, such as Guy Carleton, saw the obvious benefits of attachment and loyalty in localizing the stationing and recruitment of soldiers.

There is no definitive answer to who directly initiated the process of reform in the spring and summer of 1782. Stephen King argues that it must have been either Henry Seymour Conway, who became commander in chief in 1782, or George III. An examination of correspondence between the Commander in Chief, Henry Seymour Conway and George III during those years failed to yield conclusive evidence. ${ }^{40}$ It is most likely that Conway initiated the reform process, based upon his extensive military experience and position as Commander in Chief, his service on the Duke of Cumberland's staff in the War of Austrian Succession, the recruitment plans he submitted to the Duke of Cumberland in 1757, and his trip to Prussia in 1772. As Stephen King has discussed at some length, the reforms were actually implemented via the Deputy Adjutant General, Adam Williamson, writing to the Colonel-Proprietors of each regiment, asking if the regiment had any long standing connections to a particularly place, or if the Colonel-Proprietor himself did. ${ }^{41}$ The Colonel-Proprietors (or their factors) then replied to Williamson, but their language makes it clear that Williamson was primarily writing on behalf of Conway. Furthermore, sections of some letters make it clear that the Colonel-Proprietors

\footnotetext{
${ }^{39}$ National Army Museum, London (NAM), 2012-08-2-113 "Williamson Papers"

${ }^{40}$ British Library, Egerton MS 982.

${ }^{41}$ King, 'The 1782 British Army Reforms',
} 
believed that the adoption of county titles was in some way a royal favor or upgrade in status, indicating that George III had some role in developing the reform. ${ }^{42}$

The response of the Colonel-Proprietors to Conway and Williamson varied according to the documents at the National Army Museum. Broadly, the responses to Williamson break down into five categories, which will be explored at length. First, some regimental officers embraced the spirit of the reforms and requested counties with long-standing regimental ties. Second, whether through ignorance or personal preference, some officers requested counties which they preferred, as opposed to counties with a local connection to their regiment. Third, some officers gave tentative replies which indicated that they had no real knowledge of where their regiments had previously recruited. Fourth, some regiments with previous honorific titles resisted the reform, preferring to keep their previous royal titles. Fifth, and finally, a number of ColonelProprietors resisted the reforms outright, claiming that they did not wish to be associated with any particular county.

Many regiments desired to obtain a particular county as a result of the various local connections there. One of the most developed answers in this vein came from Sir William Boothby of the $6^{\text {th }}$ Regiment of Foot: "As the $6^{\text {th }}$ Regiment has received great spirit from the gentlemen of the county of Warwick, and the greatest part of the men being of that county we have the greatest reason to desire being called the Warwickshire Regiment, as among other advantages, we find it prevents desertions. ${ }^{43}$ Boothby connected the local identity not only with advantages in recruitment, but also suggested that having men from the same county could be a sustaining motivation which would prevent men from attempting to quit the service. Major

\footnotetext{
${ }^{42}$ NAM, 2012-08-2-113

${ }^{43}$ NAM, 2012-08-2-84
} 
General Richard Prescott of the $7^{\text {th }}$ Regiment of Foot (Royal Fuziliers) requested the area around Derby as a result of previous success in recruiting there. Earl Ligonier suggested renaming the $9^{\text {th }}$ Regiment of Foot and a discussion with his major, and replied, "Major Maney thinks that naming the $9^{\text {th }}$ 'the Norfolk Regiment' will greatly contribute to the success of recruiting parties now in that county; the nobility and gentry having on a former occasion raised a considerable sum of money to recruit the regiment." ${ }^{, 44}$ Major General Smith of the $11^{\text {th }}$ Regiment of Foot succinctly laid out three principal reasons why his regiment should be given the title of the Wiltshire Regiment. First, the regiment had received a great many recruits from that area. Second, there were a number of manufactories and towns in that part of England, so recruiting prospects continued to be good. Third, the regiment had recently been stationed there, so a number of local connections existed. ${ }^{45}$ Colonel Robert Cunningham of the $14^{\text {th }}$ Regiment replied that "the $14^{\text {th }}$ Regiment for many years [was] recruited in Bedfordshire, particularly in the town of Bedford, that it always had better success there than anywhere else, that there are a great many Bedfordshire men now in the Regiment." ${ }^{46}$ Sir Robert Hamilton of the $40^{\text {th }}$ Regiment also replied in this vein, suggesting that "the $40^{\text {th }}$ has been in a great measure recruited in Somerset and Devonshire, but principally in the former, and has in the course formed many connections with that county." ${ }^{47}$ William Haviland of the $45^{\text {th }}$ Regiment of Foot requested Nottinghamshire for his regiment, as a result of many recruits originating there, but also because the local gentry had given a cash sum to each recruit which the regiment raised there in order to facilitate better recruitment. ${ }^{48}$ Some Colonel-Proprietors went as far as to voice support for the reform movement, such as General Gabbot of the $66^{\text {th }}$ Regiment of Foot, who noted, "the design of

\footnotetext{
${ }^{44}$ NAM, 2012-08-2-87

${ }^{45}$ NAM, 2012-08-2-89

${ }^{46}$ NAM, 2012-08-2-92

${ }^{47}$ NAM, 2012-08-2-109

${ }^{48}$ NAM, 2012-08-2-111
} 
giving a name to different regiments from counties... I think will be of great utility to the service. ${ }^{49}$ The Colonel-Proprietor of the $69^{\text {th }}$ Regiment instructed his subordinates to inform Conway that "the $69^{\text {th }}$ Regiment has been recruited primarily in Lincolnshire, where the General has many connections, and the greatest part of the private men are from there. ${ }^{50}$ Many regimental commanders, then, saw great merit in the reforms, and embraced the reform as a way of strengthening the British military.

Lord Cornwallis, the Colonel Proprietor of the $33^{\text {rd }}$ Regiment, replied to Williamson at some length compared with the other letters, and his response does much to encapsulate the thinking of Colonel-Proprietors who embraced the reforms:

I am to desire that you will please to inform General Conway that the $33^{\text {rd }}$ Regiment of Infantry has always recruited in the West Riding of Yorkshire and has very good interest, and the general good will of the people in that part of the county. I should therefore wish not only to be permitted to recruit in that part of the country but that my regiment may bear the name of the $33^{\text {rd }}$ or West Yorkshire Regiment. $^{51}$

Cornwallis's response reveals the mindset of a Colonel-Proprietor who saw the need to foster and sustain local connections with a particular recruiting area, in order to build trust for the purposes of recruitment. He was also careful to ask for the numbered designation name as part of the regimental title, in addition to the county name. When officers wholeheartedly supported the reform, they did so for a variety of reasons, including hopes that it would decrease desertion, promote recruitment, and attract quality recruits to the service.

In some cases, regiments were tied to the county of the colonel's choice, rather than fostering long-standing local connections. Even Colonel-Proprietors who did not wish to take a

\footnotetext{
${ }^{49}$ NAM, 2012-08-2-127

${ }^{50}$ NAM, 2012-08-2-130

${ }^{51}$ NAM, 2012-08-2-102
} 
county name took great pains to point out the localized nature of their regiments. William Skye of the $3^{\text {rd }}$ Regiment of Foot likewise reported that "the $3{ }^{\text {rd }}$ Regiment of Foot before its departure to America was seven years in Ireland were most of its recruited were raised during that period. ${ }^{, 52}$ Skye also noted that he had a marked preference for Kent, since that was his native county, but warned General Conway against choosing Kent as he remembered difficulty in recruiting there. Conway, in this particular case, overruled his choice and assigned the $3^{\text {rd }}$ Regiment to Kent. Lt. Colonel Cathcourt of the $10^{\text {th }}$ Regiment of Foot failed to find any information regarding where the regiment had formerly been raised, and requested the county of Northumberland purely out of personal choice. ${ }^{53}$ Sir Eyre Coote, the Colonel Proprietor of the $37^{\text {th }}$ Regiment of Foot, replied for both himself and General Rains, the Colonel-Proprietor of the $44^{\text {th }}$ Regiment of Foot. In both cases, Coote selected counties for which the Colonel-Proprietors had a particular affection, not one where the regiments possessed strong local connections. ${ }^{54} \mathrm{Sir}$ Robert Pigot of the $39^{\text {th }}$ Regiment of Foot requested Staffordshire particularly, as "I am the only colonel in the army that has any property in that county... that as I reside much in the county, [I] can inspect much into the behavior and diligence of the recruiting." touch, but there is a clear sense in the letter that Pigot valued his personal connections over concerns of regimental identity. The Colonel-Proprietor of the $61^{\text {st }}$ Regiment, General Morris, requested a county outside of England, saying, "I have no wish for the $61^{\text {st }}$ Regiment bearing the name of any particular county, except the county of Aberdeen, where I had the honor of raising the late $89^{\text {th }}$ Regiment in the late war." ${ }^{, 56}$ The reforms were exclusively English in nature, and this request for a Scottish county was ignored, despite Morris' preference. Colonel-Proprietors

\footnotetext{
${ }^{52}$ NAM, 2012-08-2-81

${ }^{53}$ NAM, 2012-08-2-88

${ }^{54}$ NAM, 2012-08-2-106

${ }^{55}$ NAM, 2012-08-2-107

${ }^{56}$ NAM, 2012-08-2-124
} 
who chose counties based purely on personal preference could still impact the sense of local identity in the army as a whole but missed the point behind the reforms. These types of men appear to be rather disconnected from their regiments, a theme which we will encounter again in the next type of response.

Some Colonel-Proprietors were not well informed regarding their regiments' connection to place. General David Grame, the Colonel-Proprietor of the $19^{\text {th }}$ Regiment of Foot, sent a long, rambling answer back, in which he addressed topics from how he strongly supported the army reform, to how little his complaints regarding the position of Colonel-Proprietor had been neglected by army administration. On the subject of local connections, he suggested, "I am not very particularly informed of the... raising of the regiment. ${ }^{, 57} \mathrm{He}$ continued, tentatively suggesting that the area of Yorkshire around Leeds might be appropriate, but that he preferred somewhere in the south of Britain. Williamson, in trying to make sense of the rambling letter, noted "Leeds-Yorkshire" as the official response. ${ }^{58}$ Lt. General Parslon, the Colonel-Proprietor of the $30^{\text {th }}$ Regiment of Foot, replied that he "ha[d] no particular connection with, or attachment to, any particular county, nor any reason to wish for bearing the name of a particular county." 59 In the case of the Colonel Proprietor of the $31^{\text {st }}$ Regiment, the reply was simply, "we have no knowledge that the $31^{\text {st }}$ Regiment have any particular attachment to a county. ${ }^{\circ 60}$ Indeed, Parslon did not even bother to reply himself, leaving his regimental agent Benjamin Andrews to complete the task. Lord Cavendish, the Colonel-Proprietor of the $34^{\text {th }}$ Regiment of Foot, replied quite frankly, "as my regiment is in Canada, I can't consult them, and I don't recollect that they

\footnotetext{
${ }^{57}$ NAM, 2012, 08-2-93

${ }^{58}$ Ibid.

${ }^{59}$ NAM, 2012-08-2-99

${ }^{60}$ NAM, 2012-08-2-100
} 
had any partiality for recruiting in any particular county therefore I have no choice." ${ }^{, 61}$ Major General St. John of the $36^{\text {th }}$ Regiment of Foot informed Williamson that he was not aware of any particular attachment, but also that he wrote the regiment asking if there was more information on this subject. ${ }^{62}$ After following up with his regiment, he discovered that the men had a particular attachment to Lincolnshire. ${ }^{63}$ William Sorrell, the Colonel-Proprietor of the $48^{\text {th }}$ Regiment, likewise indicated that he would write his Lt. Colonel for more information, but no further reply is recorded in that case. ${ }^{64}$ This type of reply is indicative of potential flaws in the British Regimental System. Colonel-Proprietors did not always serve in the same location as their regiments, and some even appeared to lack fairly basic knowledge regarding the make-up of their enlisted men. More than anything else, this type of response clearly demonstrates that in many ways, the Lt. Colonel was an important connection between absentee Colonel-Proprietors and their regiments, and one of the reasons why officers such as the Duke of Cumberland prized the council of relatively junior officers such as Lt. Colonel George Howard during the War of Austrian Succession.

Many regiments had previously been distinguished by a royal name and marked out to wear coat facings of deep blue as a symbol of royal favor. Even losing the color of the facing was viewed as a great dishonor, as the men of the $2^{\text {nd }}$ Battalion of the Royal Highland Regiment (the Regiment's royal title) discovered when they were renumbered as the $73^{\text {rd }}$ Regiment of Foot:

I embrace this opportunity of sending you a Return of it, and of giving you a full account of its present state...I shall now speak of the clothing. As the Reg't we had the honour to have Royal Facings from the beginning and have done nothing to forfeit that honour, but on the contrary has been distinguished by brave

\footnotetext{
${ }^{61}$ NAM, 2012-08-2-103

${ }^{62}$ NAM, 2012-08-2-104

${ }^{63}$ NAM, 2012-08-2-105

${ }^{64}$ NAM, 2012-08-2-114
} 
behaviour, and severe sufferings, it hopes that tho separated from the Fourty Second, it will still be a Royal Highland Regt. It is not easy for me to express the anxiety felt on this account by the whole corps. The officers certainly felt is as a point of honour, and on a mischievous report being raised that the facings were to be changed, the men loudly expressed their grief and rage. I must therefore earnestly recommend this point to your most serious consideration. ${ }^{65}$

By and large, the regiments with these royal names did not want to become known by a different name, for fear of losing the honor which they currently enjoyed. General Hodgson of the $4^{\text {th }}$ Regiment of Foot (King's Own), like most of the other regiments with a previous royal name, desired to keep the regiment's current name, rather than replace it with a county name. ${ }^{66}$ General Armstrong of the $8^{\text {th }}$ Regiment of Foot (King's) was unaware of his regiment's local affiliation, and took the time to ascertain that many men had been successfully recruited from Leicestershire and Northampton, but the $8^{\text {th }}$ retained its royal title. ${ }^{67}$ Indeed, it is interesting that after the $8^{\text {th }}$ Regiment (King's), none of the responses of the less senior Royal Regiments were recorded. There is no response recorded in Williamson's papers from the $18^{\text {th }}$ (Royal Irish), $21^{\text {st }}$ (Royal North British Fuziliers), $23^{\text {rd }}$ (Royal Welch Fuziliers), $41^{\text {st }}$ (Invalids), $42^{\text {nd }}$ (Royal Highland), or $60^{\text {th }}$ (Royal American). Stephen King records all of these as "missing," but it is also possible that Williamson, realizing the great importance the Royal Regiments placed on their special relationship with the king, knew they would not desire to have an English county title. Another possibility relates to the "foreign" nature of many of these regiments. With the exception of the $21^{\text {st }}$ (Royal North British Fuziliers) and $41^{\text {st }}$ (Invalids), all of these regiments had a specific identity as Britons outside England (Irish, Welsh, Highland, and American, respectively). This may partially explain why responses are recorded from relatively senior

\footnotetext{
${ }^{65}$ MacLeod, Norman. "Letter From Col McLeod to the Col of the 73rd. 1787." Dunvegan Castle: NRAS 2950/4/752.

${ }^{66}$ NAM, 2012-08-2-82

${ }^{67}$ NAM, 2012-08-2-86
} 
Royal Regiments, which had an English origin, but not from more junior Royal Regiments, with their British, not English, regimental identities. ${ }^{68}$

Finally, some Colonel-Proprietors did not wish to be associated with a particular county, even though they were well aware that the regiment had local connections. William Dalyrimple of the $2^{\text {nd }}$ Regiment of Foot replied to Williamson, "Genl. Jones does not wish [the $2^{\text {nd }}$ Regiment] to bear the name of a particular county, but it is particularly attached to that part of Yorkshire about Halifax, Bradford, and Wakefield, having at this time, recruiting parties in those districts." ${ }^{69}$ Dalyrimple continued saying that they had "upwards of 250 men from that part of the country now in the Regiment." ${ }^{, 70}$ Lt. General Cary of the 43th Regiment of Foot indicated that though the regiment had success in recruiting near Cleavland (in the North Riding of Yorkshire) he did not "think it a sufficient reason for altering the name of the $43^{\text {rd }}$ Regiment at my time of life." ${ }^{71}$ Cary believed that he was too old, and had been Colonel too long, to warrant changing the name of his regiment. Likewise, General Maxwell, the Colonel-Proprietor of the $67^{\text {th }}$ Regiment, had a number of ideas regarding his regiment's local connections, but did not feel confident enough to choose one on his own, and wrote his Lt. Colonel regarding the situation. ${ }^{72}$ This type of response is rather infrequent, and tends to come from Colonel-Proprietors who appeared to let their regimental agents manage much of their affairs. ${ }^{73}$

Even if the Colonel-Proprietors did not always receive their first choice, there was enough response in the first category for the reforms to qualify as a success during their

\footnotetext{
${ }^{68}$ For a complete list an analysis of which regiments responded and which did not, see King, 'The 1782 British Army Reforms', 129-130.

${ }^{69}$ NAM, 2012-08-2-80

${ }^{70}$ Ibid

${ }^{71}$ NAM, 2012-08-2-110

72 NAM, 2012-08-2-128

${ }^{73}$ NAM, 2012-08-2-108
} 
implementation. Stephen King has already performed the admirable task of showing how Williamson sorted the responses, so that subject needs little addressing here. ${ }^{74}$ The response of General Evelyn of the $29^{\text {th }}$ Regiment of Foot is prime evidence that the first preference was the fostering of local connections, with Colonels' preferences forming a secondary consideration. In the letter, Evelyn writes that his own preference is for Surrey or Kent due to family connections, but that there has previously been recruiting problems in those areas. He also notes that the regiment had success in recruiting near Birmingham and Wolverhampton, but does not make a strong case either way as to what the regiment should be named. Upon reading this response, Williamson noted that the $29^{\text {th }}$ should be named the Birmingham Regiment. ${ }^{75}$ Again, as Stephen King has demonstrated, not all Colonel-Proprietors received the county they desired. In a perfect example of this kind, the Lt. General Pomeroy of the $64^{\text {th }}$ Regiment of Foot requested Warwickshire but was assigned Staffordshire in the final accounting. Even assignments like this had the potential to produce a sense of localism within a regiment.

\section{CONCLUSION}

The legacy of the reforms was mixed, partially due to the way in which they were constructed. Because Colonel-Proprietors were allowed to determine their regiments' level of participation in the reforms, not all regiments took on a local character as a result of the way. In some cases, regimental recruiting parties continued to roam, recruiting men in other regiments' districts. In some personal ways, however, the reforms had a lasting impact. James Webster, a young man from Norfolk, joined a recruiting party of the $64^{\text {th }}$ Regiment of Foot in 1779 . He served in the American War of Independence and in the early Napoleonic conflicts before being

\footnotetext{
${ }^{74}$ King, 'The 1782 British Army Reforms' 129-130.

75 NAM 2012-08-2-98
} 
posted as a recruiting sergeant in the early 1800s. As a result of the 1782 Army Reform, the recruiting station of the $64^{\text {th }}$ Regiment of Foot was placed in the county of Staffordshire, in Lichfield. There, James Webster met and married a local girl, and was discharged in Lichfield in 1814 after thirty-five years in the Staffordshire Regiment $\left(64^{\text {th }}\right)$. In the early nineteenth century, though born in Norfolk, Webster had acquired a sense of place in Staffordshire as a result of the 1782 army reforms. He died there, in the first third of the nineteenth century. The implications of Webster's experiences should not be taken too far. The localization process which the 1782 Army Reforms began would not truly be completed until the Childers Reforms in 1881 . However, for a man like Webster, the localization of military life was real enough. ${ }^{76}$

This chapter has shown that officers active in the Army Reforms of 1782 were influenced by William August, the Duke of Cumberland, and by transnational eighteenth-century military ideas. Cumberland was referenced in parliamentary debates preceding the reform, and the reforms were largely achieved through the work of a man who was Cumberland's adjutant and confidant: Henry Seymour Conway. Though Cumberland appeared to be interested in the project as early as 1749 , Conway submitted an intriguing plan for reforming the army along similar lines in the early 1750s. Military developments in Prussia held great interest for both Cumberland and Conway. Cumberland wrote short treatises on adapting "the Prussian discipline" for English purposes, whereas Conway travelled extensively in Europe in 1772, visiting Prussia at length. In the eventual adaptation of the reforms, the conscription elements which Cumberland had favored were not applied, though the idea of tying regiments to place via recruiting and titles remained. This development of administratively-fostered local military identity is significant. It demonstrates that officers believed soldiers could be motivated by the connections of local life:

\footnotetext{
${ }^{76}$ Discharge of James Webster, January $10^{\text {th }}, 1814$, TNA, WO 97
} 
that men would be less likely to desert in front of local comrades, and that tying soldiers to particular parts of the country was a potential method of cutting down on disruptive behavior. Rather than drawing on relatively anonymous men via wandering recruiting parties, many officers believed that it benefited the army to acquire men who were known quantities in their counties. More importantly in the context of this dissertation, this chapter has demonstrated the power of transnational ideas in an eighteenth-century military context. The exploration begun by Cumberland and Conway in the late 1740s finally bore fruit and was codified into practice over thirty years later in the 1782 army reforms. Through the work of elites, influenced by transnational ideas, the lived world of the British soldier was changing across the eighteenth century, becoming a world where military administration fostered local connections between soldiers and communities in the same state. England had not fully adopted all Prussian military practices, but the military experience of these two states remained firmly intertwined as the 1780s drew to a close. 


\section{Conclusion}

In this dissertation, I have explored the nature of two eighteenth-century armies. By reading the words of officers and enlisted men from Britain and Prussia between 1739 and 1789, I have shown how these men envisioned military service and expansion as well as experienced warfare and army life. My research reveals that eighteenth-century military service fits into neither fixed historiographical paradigms of limited Kabinettskriege nor modern notions of professional soldiers with a distinctive military identity. Rather, these soldiers experienced both violence and restraint in warfare, they sustained their connections to their civilian past and communities, they directed their loyalty and allegiance to God and king, and their officers explored a military world that could be both very local and transnational. These nuances and paradoxes tell us more about the nature of eighteenth-century warfare when a transnational or comparative perspective is employed in scholarship.

Fundamentally, I have argued that military historians researching eighteenth-century armies are best informed when they employ social, local, religious, and transnational perspectives. This dissertation reveals that they wrote, thought, and discussed ideas, problems, and questions that did not squarely fit into the framework of existing national historiographies. The world that these soldiers inhabited was shaped by the rise of the modern state, but the presence of the state and these national foundations did not dominate their lives or transform their worldviews the way most scholarship has suggested: soldiers became neither obedient automata fearful of their officers nor developed a military identity that divorced them from civil society. Prussian cantonists and English redcoats might have been the foot soldiers who enabled the future rise of the modern British and German Empires, but these men had little nationalistic or imperial sentiment themselves. Rather, in the era directly before the French Revolution, they 
remained concerned with localism and kinship, religious and monarchical attachments, and the concerns of daily life in their armies.

In the eighteenth-century, both the British and Prussian Kingdoms were military-fiscal states which sought to broadly expand their sphere of authority and influence. The Prussian state expanded dramatically in German Central Europe throughout the period examined by this work, and the expansion of the British Empire overseas, together with the consolidation of the Hanoverian dynasty at home, was no less dramatic. Despite these similarities, historiographic tradition from the early nineteenth century to the present day has often presented these two states as polar opposites. The British in the eighteenth century, according to this view, were a freedomloving, "polite and commercial people" who remained rightfully suspicious of a standing army and military culture; conversely, the Prussian leadership and society represented a state consumed by militarization and subordination to royal authority. Recent scholarship has done much to question these notions, particularly with reference to British colonial expansion and Prussian societal subordination. This dissertation has contributed to break down these longstanding stereotypes by including a transnational analysis of soldiers, officers, and armies. Indeed, both the British and the Prussians found their military organizations mutually intelligible, and the British even attempted to adopt systems and practices from Prussia to enhance their own military recruitment and fighting power. Even as army officers and politicians in Britain extolled the virtues of English liberty and Prussian "slavery," military authorities while on their grand tours examined Prussian military systems and attempted to reform the British system of recruitment along more Prussian lines. When faced with military failure in both the War of Austrian Succession and American War of Independence, British military reformers looked to Prussia for guidance. Their interest in replicating Prussian effectiveness overrode any concerns 
that they might have had concerning the implications of their reforms for British liberty and a looming militarization.

As officers in Britain and Prussia visited each other and reinforced stereotypes regarding each society, they also sought to understand and adopt aspects of their mutually intelligible military systems. Meanwhile, common soldiers and the local societies from which they were drawn shared many commonalities within both states. Soldiers in both the British Isles and the Kingdom of Prussia relied on family and local ties to sustain them during the hardships of war. Literate soldiers in both states wrote to their families, leaving behind limited but powerful testaments to their loyalty and ties to their local communities. These letters were not privatelykept correspondence between two individuals, but were shared communal messages constructed to bring together groups of people, both in the army and in the local village community. Soldiers passed on messages from their army comrades, relations, and friends, and inquired after a diverse set of relatives, friends, and acquaintances who had remained in their local communities when the men had marched off to war. Structural differences may account for the slight disparities between surviving British and Prussian soldiers' letters, as the postal system which allowed for easy transport of military mail in Prussia was only developed in Britain at the very end of the period examined by this dissertation.

As common soldiers leaned on their local communities for emotional support, increasing numbers of British soldiers, and a majority of literate Prussian cantonists emphasized the real presence of God in their lives. For British Methodists and Prussian Pietists and Lutherans, religious devotion shaped daily life and encouraged them to reform any negative soldierly conduct. It offered them courage and conviction in times of hardship. For the Prussian Army, often personally led by their monarch, kingly authority also played a role in developing a 
tenacious mental toughness: with God and the king on their side, these Prussian soldiers argued, they would be preserved from the disaster of defeat. For Methodists in the British Army, royal patronage also provided a potential shield against criticism of their movement: they embraced their role as servants of the king as a tactic to avoid censure. Both of these religious movements were based on an emotional belief in the sovereignty of the power of God, and the knowledge that God's love and power would shield the men from harm.

The Prussian state in the eighteenth century explicitly constructed a system of recruitment that relied on localism. Men who came from the same regions, or canton districts, were placed into the same regiments, which served to provide an informal network for these men during military service. As the experience of the foreign soldiers in the Itzenplitz Regiment demonstrates, soldiers recruited from outside Prussia, who came from diverse locales such as the Swiss Confederation and Saxony also were naturally drawn to comrades from a familiar local environment within their regiments. These natural bonds of localism in the Prussian Army strengthened the morale of soldiers in difficult circumstances, as Frederick II believed, but also provided informal networks which allowed soldiers to escape from, or endure, military service they felt was harsh or unjust. In the British Army, although some regiments maintained a practice of local recruiting throughout the period, this impulse was given a developed shape in the 1782 Army Reforms, when many of the first seventy infantry regiments were provided with a local recruiting district designed to cultivate local ties to the regiment, support military expansion and civil-military relations.

Just as soldiers in both states drew on localism during army life, they also existed in a shared world of horrifying combat carnage as well as restrained violence toward civil society. Monitored by their officers and military administration, soldiers kept violent depredations 
against friendly civilians in check. The military administrations of both states worked carefully to ensure that soldiers did not create friction in civilian society and answered petitions which called for the removal of rowdy soldiers when they caused problems in local communities, particularly during peacetime. Crime, looting, rape, and murder still followed eighteenth-century armies across the landscape of Europe and the world, but when compared with the experiences of soldiers in other eras, eighteenth-century warfare generally limited acts of aggression against civilians and civil society. That this was true in both Britain and Prussia is another sign of the commonalities and shared experiences to which we can refer as 'military Europe'.

In all of these areas: the emergence of the military public sphere, familial letter writing among common soldiers, religious sentiments and monarchical authority, localism and its administrative use, and the experience of a restrained violence toward civilians, British and Prussian soldiers experienced a similar world, and developed similar worldviews. This does not mean that important differences did not exist; obviously, these armies were not identical. In areas such as tactical, operational, and strategic doctrine; uniform design; generalship; and economic administration, differences persisted. From the areas under study, however, it does not appear that one army emerged as the product of a polite and commercial people on the road to Whiggish parliamentary progress, while the other progressed slowly into the darkness of authoritarian militarism. These two eighteenth-century armies exhibited more similarities than differences, and were more mutually intelligible than separated by vast gulfs in structure. The evidence for this is clear in the writings of common soldiers, whose lived experience demonstrates the shared qualities in both armies. The evidence is also clear in the writings of officers, who sought actively to make the two armies resemble one another more closely. If the evidence of these similarities is clear, what do they signify for historians? 
Fundamentally, this dissertation concurs with a recent generation of scholarship on the Prussian Army, best exemplified by writings of Martin Winter, which rejects "the conclusion that during the eighteenth century the Prussian military system created a particularly submissive people on the far side of the Elbe." Winter hoped that "more ... research into BrandenburgPrussia, which deals with the actual living and service conditions of soldiers, will paint a more differentiated picture of the network of relationships between the military and society." This dissertation has taken up Winter's challenge, which serves as a promising guidepost for military historians as they revisit conventional historiographies and even default stereotypes that are informed more by the nineteenth and twentieth centuries than by the times when the armies in question actually fought, marched and pitched camp across Europe and the globe.

This dissertation asserts that the history of the British Army is best understand when studied in conjunction with other European military forces, rather than as an island unto itself. Though significant British military peculiarities and idiosyncrasies existed, the British fought as a portion of larger European coalition force in all of their eighteenth-century wars, as Mark Wishon has pointed out. This is equally true of the American War of Independence, which is too often examined in isolation from contemporary European military events. The British Army possesses a unique and storied history, and we can best understand the uniqueness of that story when we understand it in relation to its other contemporaries and cousins. Recent work, by historians such as Tobias Röder, has demonstrated this for the eighteenth century, and hopefully such illuminating lines of research will continue to be pursued. ${ }^{2}$

\footnotetext{
${ }^{1}$ Martin Winter, Untertanengeist durch Militärpflict: Das Preussische Kantonsystem in brandenburgischen Städten im 18. Jahrhundert, (Bielefeld, 2005), 466.

${ }^{2}$ Tobias Röder, "Professional Identity of Army Officers in Britain and the Habsburg Monarchy, 1740-1790", (unpublished doctoral dissertation, University of Cambridge, 2019).
} 
This study contributes to the historiography of modern states, their narrative history and trajectories by reinforcing the now commonly held idea that if a different German developmental path exists, one that explains the horrors of the early twentieth century in German history, the divergence of this path was not clearly present in eighteenth-century Prussian society. Likewise, as historians increasingly criticize the imperial policies of the British Empire in the eighteenth century, it is important carefully to contextualize and historicize the actions taken by eighteenthcentury military fiscal states as they recruited, trained, and battled their way across the globe. These states were primarily driven by a desire to expand their power, wealth, and territorial holdings. Over the span of modern history, it is possible to blame both Britain and Prussia for many of the ills of the currently facing the twenty-first century world. Societal deference to military authority, heightened military spending, settler colonialism, and imperialism were not resolved in the mid-twentieth century. As such it is eminently possible that future historians searching for the divergent developmental roots of these ills will point to both of these eighteenth-century states, and their military policies, as the cause. This dissertation asserts that such conclusions need to be carefully historicized, backed with copious evidence, and evaluated with a careful eye to historical agency over time.

Common soldiers, whether they were ploughboys from Staffordshire or Büdnerei from Stavenow, used the medium of letter-writing to retain firm connection to the local, familyoriented worlds they had left behind, even as they embraced religious and monarchical military worldviews. Far from only forging a new soldierly identity against civilians, these men retained deep ties to the civilian world, and did not have their civilian identities completely reconstructed by military service. Just a generation ago, historians asserted that eighteenth-century soldiers were an illiterate underclass of men only capable feeling a vague notion of esprit de corps drilled 
into them by rote military instruction. This dissertation, joining a growing chorus of scholarship, shows that eighteenth-century soldiers were far more complex than this shallow, twodimensional portrait indicates. As scholarship on eighteenth-century soldiers moves into the middle decades of the twenty-first century, historians should allow the voices of soldiers to form the center of the narrative, rather than taking the overbearing writings of military elites at face value. Historians should demonstrate that the lives of these men did not begin or end with their military service, that their military service encompassed more than individual wars, that the similarities of their experiences did not stop at state boundaries. These proud soldiers took their military responsibilities seriously but also retained a connection to their former civilian worlds. 


\section{Bibliography}

In order to retain clarity in the bibliography, sources cited and or utilized have been listed; this is not a bibliography of all sources consulted for this dissertation.

\section{Manuscript Sources:}

\section{$\underline{\text { Austrian Manuscript Sources }}$}

Österreichisches Staatsarchiv, Vienna

KA-Kriegsarchiv, Kriegsakten

\section{British Manuscript Sources}

Bedfordshire and Luton Archives and Record Service, Bedford

R 769, "Sgt. John Harvey to the Duke of Beford"

ABM1779-1782 "Marriage Bonds and Allegations"

Berkshire Record Office, Reading

R/D/134/13 “George Dawson to his Mother”

D/EN/F54 "Journal of a Tour in Switzerland and Italy, 1744"

Bodleian Library, Oxford

English Historical Manuscripts C 282, "Narrative of General Conway’s Tour”

British Library, London

King's Manuscripts, 240 "Sir David Dundas, 'Memorandum"”

King's Manuscripts, 241 "Sir David Dundas, 'Remarks on the Prussian Troops and their Movements"”

European Manuscripts, B296 “Letters and other Papers of Samuel Hickson”

Dorset History Centre, Dorchester

D/WIB/C/93, "Letter from Robert Honeyborne to his wife, Jane"

PE-BF/OV/5 "Blandford Parish, Overseers of the Poor, Settlement and Removal Papers" 
Dunvegan Castle Archives, Dunvegan,

MacLeod Papers, Norman MacLeod, NRAS 2950/4/752 "Letter from Col. McLeod to the Col. of the $73^{\text {rd }}, 1787^{\prime \prime}$

Gloucestershire Archives, Gloucester

D4582 Bowly Family of Cirencester

D153 Jackson Family of Sneyd Park

Lambeth Palace Library, London

Beloe Papers, MS 3263

Lancashire Archives, Preston

DDX 2743/MS5237 "William Smith to his Wife"

QSP/1996/9, “William Bromley to his Father”

National Archives of the United Kingdom, Kew (TNA)

Foreign Office: FO 95/5/3

High Court Admiralty Papers: HCA 30/272/3

Home Office: HO 42/46/32

State Papers: SP 36/72/124

SP 36/84/2/8

SP 54/26/122

War Office: WO 7/25

WO 28/8/137

WO 40/3

WO 97 
National Records of Scotland, Edinburgh

Papers of the Ogilvy family, Earls of Seafield, GD248/509/3/74 "Letter from Duncan Grant to his father"

Norwich University Kreitzberg Library Special Collections, Northfield

356.10943 P972n "New Regulations for the Prussian Infantry, Signed Christopher Darby, January $9^{\text {th }}, 1784$ "

Royal Archives, Windsor

Cumberland Papers, Main Series.

Templer Study Centre, National Army Museum, London (NAM)

1976-07-40 "Letter of James Castle, 1743"

1986-11-1 'Letters of Sergeant Calder' 1778-1785

1986-12-38-116 'Papers of Alexander Dury’

2008-06-4 "Letter of Private W. Hopkins"

2010-11-16, "Roger Lamb Scrapbook"

2012-08-2 "Papers of Adam Williamson"

West Sussex Record Office, Chichester

RSR/MSS/1/16 "Derby Mercury print of a letter from a soldier in the $35^{\text {th }}$ Regiment"

\section{German Manuscript Sources}

Brandenburgisches Landeshauptarchiv, Potsdam-Golm (BLHA)

Rep. 2A III, Nr. D9607

Rep. 2 Kurmarkischer Kammer, Nrs: D4041, F5342, S2152, S6432 S6482/1, S6483 , S6964, S7206

Rep. 3 Neumarkischer Kammer, Nrs.: 6688, 7288, 9203

Rep. 3B III, Nr. D913

Rep. 6B Soldin, Nr. 184; 
Rep. 17B, Nr. 3529

Rep. 19 Lindow/M 60;

Rep. 19 Potsdam, Nrs. 1162, 1277, 1568, 1571, 1576, 2472

Rep. 23A, Nr. A 116, Nr. B 1794, Nr. C 1921;

Rep. 23B, Nr. 2936.

Rep. 37 Neuhardenburg, Nr. 1571, "Militaria Anglica".

Geheimes Staatsarchiv Preußischer Kulturbesitz, Berlin-Dahlem (GStAPK)

Hauptabteilung IV Rep. 15A, Nr. 610, Rélation von der Bataille von Lowositz am Iten Oktober 1756

Hauptabteilung X, Rep. 37 Stavenow Nr. 496 "Letter of Hans Wolcke"

Hessisches Hauptstaatsarchiv, Wiesbaden (HHStAW)

Fonds 133, No. 11670 "Letter of Philipp Reihard Weingarten"

Hessissches Staatsarchiv, Darmstadt (HStAD)

Bestand D 4, Nr. 530/5 "Prussian Army Files"

Bestand G 28, Nr. F 2017 "Letters of Philipp Wolfenstaedter"

Bestand O 59, Nr. 10 "Köhler Family Correspondence"

\section{$\underline{\text { United States Manuscript Sources }}$}

Society of the Cincinnati Library, Washington, D.C.

MSS L1992.1.477, "Gibraltar Orderly Book”

MSS L2017F30, "Duke of Cumberland's Orderly Book" 


\section{Published Primary Sources:}

Agar, William. Military Devotion: or the soldier's duty to God. London: P. Brindley, 1758.

Adams, John Quincy. Letters on Silesia: Written During a Tour Through that Country. London: J Budd, 1804.

Aldersberg, Joseph Berhandtsky von. Der Graf von Sonnetnthal oder: Das Schicksal des Soldaten. Munich: Churfürstlichen Genehmhaltung, 1777.

Alicia, Rosalind. et al., Report on the Manuscripts of Mrs. Franklin-Russell-Astley: of Chequers Court, Bucks .London: Historical Manuscripts Commission, 1900.

Anonymous. The Annul Register for the Year 1758. London: Dodsley, 1764.

Anonymous, The Arminian Magazine. London: J. Fry \&, 1778

Anonymous. British Glory Reviv'd. London, J. Roberts, 1743.

Anonymous. The Methodist Magazine for the Year 1799, being a continuation of the Arminian Magazine. London: G. Whitfield, 1799.

Anonymous. Offizier-Lesebuch, Historisch-Militärischen Inhalts, mit untermischten interessanten Anekdoten, von einer gesellschafts militärischer Freunde. Berlin: C. Matzdorff's Buchhandlung. 1793

Anonymous. The Parliamentary Register or History of the Proceedings and Debates of the House of Commons. London: J. Almon, 1780.

Anonymous. Sammlung ungedruckter Nachrichten. 5. Dresden: Waltherischen Buchhandlung, 1782.

Archenholz, Johann Wilhelm von. England und Italien. 2. Leipzig: Dykischen Buchhandlung, 1787.

Barsewisch, Ernst von. Meine Kriegs-Erlebnisse während des Siebenjährigen Krieges, 17571763. Berlin: Warnsdorff, 1863.

Berenhorst, Georg Heinrich von and Eduard von Bülow. Aus dem Nachlasse von Georg Heinrich von Berenhorst. Dessau: K. Aue, 1845.

Berner, Ernst. and Gustav Berthold Volz. Aus der Zeit des Siebenjährigen Krieges: Tagebuchblätter und Briefe der Prinzessin Heinrich und des Königlichen Hauses. Berlin: Duncker, 1908. 
Büschel, Johann. Neue Reisen eines Deutschen nach und in England im Jahre 1783. Berlin: Friedrich Mauer, 1784.

Blaufarb, Rafe. and Claudia Liebeskind, Napoleonic Foot Soldiers and Civilians: a Brief History with Documents. Bedford: St. Martin's, 2011.

Bleckwenn, Hans. Preussische Soldatenbriefe. Osnabrück: Biblio Verlag, 1982.

Boswell, James. Journal of his Swiss and German Travels. London: 1764.

Bräker, Ulrich. Lebensgeschichte und Natürliche Abentheuer eines Armen Mannes von Tockenburg. Zurich: Hans Heinrich Füssli, 1789.

Cornwallis, Charles. Correspondence of Charles, First Marquis Cornwallis. 3. London: 1859

Cogniazzo, Jakob de. Geständnisse eines Oesterreichischen Veterans. 2. Breslau: Löwe, 1791.

Cope, John. et al. The Report of the Proceedings and Opinion of the Board of General Officers, on Their Examination into the Conduct, Behaviour, and Proceedings of, Sir John Cope, Peregrine Lascelles, and Thomas Fowke, from the Time of the Breaking out of the Rebellion in North-Britain in the Year 1745, till the Action at Preston-Pans Inclusive. London: W. Webb, 1749.

Cranfield, Richard. The Christian; a Memoir of Thomas Cranfield. London: Religious Tract Society, 1844.

Dillon, John. A Short Account of Mr. John Dillon, Preacher of the Gospel. Written by Himself. London: Printed for G. Whitfield, 1796.

Dittfurth, Franz Wilhelm von. Zehn Schöne neue Lieder aus dem Siebenjährigen Kriege. Berlin: Trowisch und Sohn, 1851. geschichtlichen und sonstigen Erläuterungen. Berlin: Franz Lipperheide, 1871.

Dominicus, Johann Jakob. eds. Dietrich Kerler, Aus dem Siebenjährigen Krieg. Tagebuch des preußischen Musketiers Dominicus. Munich: C.B. Beck’sche Verlag, 1891.

Doddridge, Phillip. Some Remarkable Passages in the Life of the Honourable Col. James Gardiner: Who Was Slain at the Battle of Preston-Pans, September 21, 1745. Printed for J. Buckland, W. Strahan, J. and F. Rivington, Hawes, Clarke and Collins, W. Johnston, S. Crowder, 1772

Douglas, James. Travelling Anecdotes: through Various Parts of Europe. London: J. Debrett, 1782. 
Dreyer, Jospeh Ferdinand Leben und Taten eines Preussischen Regiments-Tambours von ihm selbst beschrieben in seinem 93ten Lebenjahre. Altpreussischer Komimiss 22. Osnabrück: Biblio, 1975 [1810].

Du Roi, August Wilhelm. Journal of Du Roi the Elder. Philadelphia: University of Pennsylvania Press, 1911.

Eckarthausen, Carl. Erzählungen für empfindsame Herzen an Sonnabenden nach der Arbeit. Munich: Strohl, 1784.

Eddie, S.A. Freedom's Price: Serfdom, Subjection and Reform in Prussia, 1648-1848. Oxford, Oxford University Press, 2013

Fonblanque, Edward. Political and Military Episodes in the Latter Half of the Eighteenth Century. London: MacMillan, 1876.

Foote, Jeffrey. A Defence of the Planters of the West-Indies. London: J. Debrett, 1792.

Friedrich II, Instruktion für die Commandeurs die Infanterie-Regimenter, 11 May, 1763. Oeuvres de Frederic le Grand. 30. Berlin: 1846-1867.

Guibert, Jacques-Antoine-Hippolyte comte de. trans. Joseph Johnson, Observations on the military establishment and discipline of the King of Prussia. London: Fielding and Walker, 1780.

1773. Paris, 1803.

Haller, Franz Ludwig von. Militärischer Charakter und Merkwürdige Kriegsthaten Friedrich des Einzigen: Königs von Preussen: Nebst einem Anhang Über einige Seiner Berühmtesten Feldherren und verschiedene Preussische Regimenter. Berlin: Bei Oemigke Dem Jüngern, 1796.

Helfferich, Tryntje. .The Thirty Years War: a Documentary History. Indianapolis: Hackett, 2009.

Herrmann, O. "Prinz Ferdinand Von Preussen über Den Feldzug Vom Jahre 1757," Forschugen XXXI 1918.

Hildebrandt, C. Anekdoten und Charakterzüge aus dem Leben Friedrichs des Grossen. 2. Halberstadt: Brüggemannn, 1829.

Hoyer, Johann Gottfried von. Geschichte der Kriegskunst. Rosenbusch: 1797.

Jackson, Robert. A Systematic View of the Formation, Discipline, and Economy of Armies. London: Stockdale, 1804. 
Jackson, Thomas. The Lives of Early Methodist Preachers: Chiefly Written by Themselves. 4. London: Wesleyan Conference Office, 1875.

Jany, Curt. "Briefe Preussischer Soldaten aus den Feldzügen 1756 und 1757 und über die Schlachten bei Lobositz und Prag," in Urkundliche Beiträge Und Forschungen Zur Geschichte Des Preussischen Heeres. Berlin: E.S. Mittler, 1901.

Kaltenborn, Rudolph Wilhelm von. Briefe eines alten Preussischen Officiers verschiedene Characterzüge Friedrichs Des Einzigen Betreffend. Hohenzollern, 1790.

Kessler, Christian David. et al. Neues Journal für Prediger. Halle: Karl August Kummel, 1807.

Kohl, Rolf Dieter. "Ein Brief des Wiblingwerder Bauernshones Johann Hermann Dresel aus dem Siebenjährigen Krieg, Die Märker, Volume 28, No. 3 (1979) 82-4.

König, Anton Balthasar. Biographisches Lexikon aller Helden und Militairpersonen. 3. Berlin: Wever, 1790.

Küster, Carl Daniel. Des Preussischen Staatsfeldpredigers Küster, Bruchstück Seines Campagnelebens im Siebenjährigen Kriege ... Nebst einem vorbericht des königl. Herrn Oberkonsistorialraths Sack. Zweyte ... Stark Vermehrte Ausgabe. Berlin: Karl Massdorfs, 1791.

Lange, Eduard. Die Soldaten Friedrich's Des Großen. Leipzig: Avenarius \& Mendelssohn, 1852.

Lafayette, Marquis de. Memoirs, Correspondence and Manuscripts of General Lafayette. 3. London: 1837.

Liebe, Georg Preußische Soldatenbriefe aus dem Gebiet der Provinz Sachsen im 18. Jahrhundert. Halle/Salle: Gebauer Schwetschke, 1912.

Lojewsky, J. G. Selbstbiographie des Husaren-Obersten von... ly; Oder, Meine Militairische Laufbahn im Dienste Friedrichs des Einzigen. Leipzig: C.Y. Kollmann, 1843.

Lossow, Ludwig von. Denkwürdigkeiten zur Charakteristik der Preussischen Armee unter dem Grossen König Friedrich Dem Zweiten. Glogau: Carl Heymann, 1826.

Mauvillon, Éléazar de. The History of Prussia, Particularly During the Reign of the Late King Frederick William. London: R. Manby, 1756.

Mercoyrol, Jacques de. Campagnes De Jacques De Mercoyrol De Beaulieu, Capitaine Au régiment De Picardie (1743-1763). ed. Vogüé Melchior and Auguste Le Sourd. Paris: Renouard, H. Laurens, successeur, 1915. 
Mirabeau, H. G. and J. Mauvillion, Systeme Militaire de la Prusse et Principes de la Tactique Actuelle des Troupes les plus Perfectionnees. Extrait de la Monarchie Prussienne. London: 1788.

Miranda, Fransico de. Archivo del General Miranda. 23. Caracas: Parra Leon Hermonas, 19291950.

Moore, John. A View of Society and Manners in France, Switzerland, and Germany. 2. London: 1770.

Morris, Margaret. Private Journal Kept During a Portion of the Revolutionary War, for the Amusement of a Sister. Philadelphia: 1836

Moritz, Carl P. Reisen eines Deutschen in England im Jahr 1782, In Briefen an Herrn Oberkonsistorialath Gedike. 1783.

Parkinson, James. The Soldier's Tale, Extracted from the Village Association. London: Eaton, 1793.

Pollnitz, Karl Ludwig Memoirs of Charles Louis, Baron de Pollnitz, 3. London: Daniel Browne, 1737.

Pouchot, Pierre. Memoirs of the Late War in North America between France and England. trans. Michael Cardy. ed. Brian Leigh Dunnigan. Youngstown: Old Fort Niagara Association, 2004.

Reisbeck, Johann K. Briefe eines reisenden Franzosen über Deutschland an seinen Bruder zu Paris. 2. 1784.

Retzow, Friedrich A. von. Charakteristik der Wichtigsten Ereignisse des Siebenjährigen Krieges, in Rücksicht auf Ursachen und Wirkungen. Berlin: Himburg, 1802.

Schimmel, Johann Christian. "Kurze Lebensbeschreibung des preussischen Veterans Johann Christian Schimmel," Zeitschrift für Kunst, Wissenschaft, und Geschichte des Krieges, Volume 10, No.4-6 (1827).

Sidney, Edwin. The Life, Ministry, and Selections from the Remains of the Rev. Samuel Walker. London, 1838.

Seipp, Christoph. Reisen von Preßburg durch Mähren, beyde Schlesien u. Ungarn nach Siebenbürgen. Frankfurt und Leizpig: 1793.

Täge, Christian. “K Istorri Semiletnei Voiny, Zapiski Pastora Tege,” Russkii Akchiv,, (1864).

Telford, John. Wesley's Veterans: Lives of Early Methodist Preachers. 7. Salem, OH: Schmul Publishers, 1912. 
Trenchard, John and Thomas Gordon, A Collection of Tracts by the Late John Trenchard. London: Cogan, 1751.

Vattel, Emmerich de. trans. Joseph Chitty, The Law of Nations, or Principles of the Law of Nature, Philadelphia: Johnson, 1844.

Volz, Gustav Berthold. Die Politischen Testamente Friedrich's Des Großen. Berlin: Hobbing, 1920.

Walter, Jakob. and Marc Raeff, ,The Diary of a Napoleonic Foot Soldier. Moreton: Windrush, 1999.

Washington, George. The Papers of George Washington. Revolutionary War Series, Volume 6, 13 August 1776-20 October 1776. eds. Philander D. Chase and Frank E. Grizzard, Jr. Charlottesville: University Press of Virginia, 1994.

Wesley, John. The Journal of the Rev. John Wesley, A.M. ed. Thomas Jackson, 2. London: Wesleyan Conference Office, 1869.

Witzleben, Gerhard August von. Aus Alten Parolebüchern der Berliner Garnison zur Zeit Friedrichs des Grossen. Berlin, 1851.

Zander, Christian F. Fundstücke - Dokumente und Briefe einer Preußischen Bauernfamilie: (1747 - 1953). Hamburg: Kovacì, 2015.

Zimmermann, Johann Georg . Ueber Friedrich den Grossen. Wien: Ofen, 1788

\section{Secondary Sources:}

\section{Published Sources:}

Abraham William J. and James E. Kirby, eds., The Oxford Handbook of Methodist Studies. Oxford: Oxford University Press, 2009.

Ancell, Samuel. A Circumstantial Journal of the Long and Tedious Blockade and Siege of Gibraltar from the 12th of September, 1779, to the 23d. of February, 1783, Etc. Cork: A. Edwards, 1793.

Anderson, Fred. A People's Army: Massachusetts Soldiers and Society in the Seven Years' War. Chapel Hill, University of North Carolina Press, 1984.

Crucible of War: The Seven Years War and the Fate of Empire in British North America, 1754-1766. New York: Alfred A Knopf, 2000. 
Anderson, M.S. War and Society in Europe of the Old Regime. London: Leicester University Press, 1988.

The War of Austrian Succession 1740-1748. London: Routledge, 1995.

Babel, Rainer et al, eds., Grand Tour: Adeliges Reisen und europäische Kultur vom 14. Bis zum 18. Jahrhundert: Akten der Internationalen Kolloquien in der Villa Vigoni 1999 und im Deutschen Historischen Institut Paris 2000. Ostfildern: Thorbecke, 2005.

Babits, Lawrence. A Devil of Whipping: The Battle of Cowpens. Chapel Hill, University of North Carolina Press, 2001.

Babits, Lawrence. et al, Long, Obstinate and Bloody: The Battle of Guilford Courthouse. Chapel Hill, University of North Carolina Press, 2009.

Berkovich, Ilya. "Fear Honour, and Emotional Control on the Eighteenth Century Battlefield," in Battlefield Emotions: 1500-1800, Practices, Experience, Imagination, eds. Erika Kuijpers and Cornelius van der Haven, (London: Palgrave Macmillan, 2016).

Motivation in War: The Experience of Common Soldiers in Old-Regime Europe. Cambridge: Cambridge University Press: 2017.

Bernhardi, Theodor von. Friedrich der Grosse als Feldherr. Berlin: E.S. Mittler und Sohn, 1881.

Bernstein, Paul. and Robert Green. History of Civilization, Volume I: to 1648. New York: Littlefield Adams, 1976.

Birgfeld, Johannes. Krieg und Aufklärung: Studien zum Kriegsdiskurs in der deutschsprachigen Literatur des 18. Jahrhundert. Hannover: Wehrhahn, 2012.

Blackbourn, David and Geoff Eley. The Peculiarities of German History: Bourgeois Society and Politics in Nineteenth-Century Germany. Oxford, Oxford University Press, 1984.

Blanning, Timothy. The Pursuit of Glory: Five Revolutions that Made Modern Europe,16481815. London: Penguin, 2008.

Frederick the Great: King of Prussia. Random House: New York, 2016.

Boer, Roland. "EP Thompson and the Psychic Terror of Methodism," Thesis Eleven 110, no. 1 (2012): 54-67.

Bohls, Elizabeth A. et al, eds, Travel Writing, 1700-1830: an Anthology. Oxford: Oxford University Press, 2008.

Boland, Irene et al, Eutaw Springs: The Final Battle of the American Revolution's Southern Campaign. Columbia: University of South Carolina Press, 2017. 
Bonomi, Patricia U. Under the Cope of Heaven. New York: Oxford University Press, 1986.

Bowler, Arthur. Logistics and the Failure of the British Army in America, 1775-1783. Princeton: Princeton University Press, 1975.

Brewer, John. and Eckhart Hellmuth, Rethinking Leviathan: The Eighteenth-Century State in Britain and Germany. Oxford: Oxford University Press, 1999.

Browning, Reed. The War of the Austrian Succession (St. Martin's: Griffin, 1993

Büsch, Otto. Militärsystem und Sozialleben im alten Preußen: Die Anfänge der sozialen Militarisierung der preußisch-deutschen Gesellschaft 1713-1807. Berlin: Walter de Gruyter, 1962.

-----------. trans. John G. Gagliardo. Military System and Social Life in Old Regime Prussia, 1713 - 1807 the Beginnings of the Social Militarization of Prusso-German Society. Boston: Humanities Press, 1997.

Butler, Jon. Awash in a Sea of Faith. Cambridge: Harvard University Press, 1990

Campbell, Alexander. The Royal American Regiment: An Atlantic Microcosm. Norman: University of Oklahoma Press, 2010.

Carlyle, Thomas. History Friedrich II of Prussia, Called Frederick the Great. London: Estes and Lauriat, 1858.

Charters, Erica et al.,Civilians and War in Europe, 1618-1815. Liverpool: Liverpool University Press, 2014.

Childs, John Armies and Warfare in Europe: 1648-1789. Manchester: Manchester University Press, 1989.

---------, "The Army and the State in Eighteenth-Century Britain and Germany," In Rethinking Leviathan: The Eighteenth-Century State in Britain and Germany. eds. John Brewer and Eckhart Hellmuth. Oxford: Oxford University Press, 1999.

Churchill, Winston. A History of the English Speaking Peoples: The Age of Revolution. 4. London: Cassell, 1956.

Clark, Christopher. Time and Power: Visions of History in German Politics, from the Thirty Years War to the Third Reich. Princeton: Princeton University Press, 2019.

Cleare. G.H. "County Names for the regiments in 1782," Journal of the Society for Army Historical Research, Vol. 36, No. 145 (March 1958) 34-38 
Clodfelter, Micheal. Warfare and Armed Conflicts: a Statistical Encyclopedia of Casualty and Other Figures, 1492-2015. Jefferson: McFarland \& Company, 2017.

Colley, Linda. Britons: Forging the Nation, 1707-1837. London: Pimlico, 2003.

Collins, Kenneth J. A Wesley Bibliography. Wilmore: First Fruits Press, 2017.

Conway, Stephen. "The British Army, "Military Europe," and the American War of Independence." The William and Mary Quarterly 67, no. 1 (2010): 69-100.

Cormack, Andrew E. "These Meritorious Objects of the Royal Bounty": The Chelsea OutPensioners in the Early Eighteenth Century. London: Henry Ling, 2017.

Delbrück, Hans. Die Strategie des Perikles erläutert durch die Strategie Friedrichs des Grossen: Mit einem Anhang über Thucydides und Kleon. Berlin: Georg Reimer Verlag. 1890.

Devine, Thomas. The Scottish Clearances: A History of the Dispossessed, 1600-1900. London: Allen Lane, 2018.

Duffy, Christopher. The Army of Frederick the Great. $1^{\text {st }}$ Edition. London: Hippocrene Books, 1974 ,

Fire and Stone: The Science of Fortress Warfare, 1660-1800. London: Peters, Fraser, and Dunlop, 1975.

. Russia's Military Way to the West: Origins and Nature of Russian Military Power, 1700-1800. Routledge: London, 1981.

-. The Military Experience in the Age of Reason. New York: Atheneum, 1988. -. The Army of Frederick the Great. $2^{\text {nd }}$ Edition. Chicago: Emperor's Press, 1994. By Force of Arms: The Austrian Army in the Seven Years War. Chicago: Emperor's Press, 2008.

Fight for a Throne: The Jacobite '45 Reconsidered. London: Helion, 2014.

Dwyer, Phillip. 'It Still Makes Me Shudder': Memories of Massacres and Atrocities during the Revolutionary and Napoleonic Wars', War in History, Vol. 16 Issue 4, (2009), 381-405. . "Violence and the revolutionary and Napoleonic wars: massacre, conquest and the imperial enterprise," Journal of Genocide Research Vol. 15, No. 2, (2013) 117-131

Eckhardt, William. “Civilian Deaths in Wartime," Bulletin of Peace Proposals 20, no. 1 (1989): 89-98. 
Eglin, John. Venice Transfigured: the Myth of Venice in British Culture, 1660-1797. New York: Palgrave, 2001.

Engelen, Beate. Soldatenfrauen in Preußen: Eine Strukturanalyse der Garnisonsgesellschaft im späten 17. und im 18. Jahrhundert. Lit, 2005.

-------------. "'Fremde in Der Stadt: Die Garnisongesellschaft Prenzlaus Im 18. Jahrhundert,"" in Die Herkunft Der Brandenburger : Sozial-Und Mentalitätsgeschichtliche Beiträge Zur Bevölkerung Brandenburgs Vom Hohen Mittelalter Bis Zum 20. Jahrhundert, ed. Jürgen Theil, Olaf Gründel, and Klaus Neitmann (Potsdam, 2001), 116-120.

Englund, Peter. The Battle That Shook Europe: Poltava and the Birth of the Russian Empire. London: I.B. Tauris, 2013.

Ferling, John. Almost a Miracle: The American Victory in the War of Independence. New York: Oxford University Press, 2007.

French, David. Military Identities: The Regimental System, the British Army, and the British People, 1870-2000. New York: Oxford University Press, 2008.

Frey, Sylvia. The British Soldier in North America: A Social History of Military Life in the Revolutionary Period. Austin: University of Texas Press, 1981.

Fiedler, Siegfried. Kriegswesen und Kriegführung im Zeitalter der Kabinettskriege. Koblenz: Bernard \& Graef, 1986.

Forrest, Alan. Napoleon's Men: The Soldiers of the Revolution and Empire. New York: Continuum International Publishing, 2006.

Füssel, Marian "Féroces et barbares? Cossacks, Kalmyks, and Russian Irregular Warfare during the Seven Years War," in The Seven Years War: Global Views. eds Mark Danely and Patrick Speelman. Boston: Brill, 2012.

. "Emotions in the Making: The Transformation of Battlefield Experiences during the Seven Years War" in Battlefield Emotions 1500-1800: Practices, Experience, and Imagination, eds. Erika Kuijpers and Cornelius van der Haven. London: Palgrave Macmillan, 2016.

Der Preis des Ruhms: Eine Weltgeschichte des Siebenjährigen Krieges, 17561763, Munich: C.H. Beck, 2019.

Gawthrop, Richard L. Pietism and the Making of Eighteenth-Century Prussia. Cambridge: Cambridge University Press, 1993.

Gooch, George P. History and Historians in the Nineteenth Century. London: Longman, 1913. 
Griep, Wolfgang et al, eds., Reisen im 18. Jahrhundert: Neue Untersuchungen. Heidelberg: C. Winter, Universitätsverlag, 1986

Grimsley, Mark. and Clifford Rogers, Civilians in the Path of War. Lincoln: University of Nebraska Press, 2002.

Gritsch, Eric. "Luther and the State: Post-Reformation Ramifications," in Luther and the Modern State in Germany. ed. James Tracey. Kirksville: Missouri, 1986.

Gruber, Ira D. Books and the British Army: in the Age of the American Revolution. Chapel Hill: University of North Carolina Press, 2010.

Hagen, William W. Ordinary Prussians: Brandbenburg Junkers and Villagers 1500-1840. Cambridge: Cambridge University Press, 2002.

Hagist, Don. British Soldiers, American War: Voices of the American Revolution. Yardley: Westholme, 2014.

Hagist, Don. Noble Volunteers: The British Soldiers who Fought the American Revolution. Yardley: Westholme, 2020

Hamilton, Phillip and Glenn Moots, Justifying Revolution: Law, Virtue, and Violence in the American War of Independence. Norman: University of Oklahoma Press, 2018.

Harari, Yuval N. Ultimate Experience: Battlefield Revelations and the Making of Modern War Culture, 1450-2000. London: Palgrave Macmillan, 2014.

Hayter, Anthony J. The Army and the Crowd in Mid-Georgian England. London: The MacMillan Press, 1978.

Heathorn, Stephen. "E.P. Thompson, Methodism, and the 'Culturalist' Approach To the Historical Study of Religion," Method \& Theory in the Study of Religion 10, no. 2 (1998): 210-226.

Hempton, David . Methodism and Politics in British Society, 1750-1850. London: Routledge, 1984.

Heyden, Hellmuth. "Die Kirchenpolitik in Pommern von der Teilung des Landes 1648 bis zur Mitte des 19. Jahrhunderts." Baltische Studien. No. 57 (1971).

Hinrichs, Carl. Preussentum und Pietismus: Der Pietismus in Brandenburg-Preussen als Religiössozial Reformbewegung. Göttingen: Vandenhoeck \& Ruprecht, 1971.

Hintze, Otto. "Die Epochen Des Evangelischen Kirchenregiments in Preussen," in Regierung und Verwaltung: Gesammelte abhandlungen zur Staats-, Rechts- und Sozialgeschichte Preussens (Göttingen: Vandenhoeck und Ruprecht, 1967), pp. 56-96.Carl Hinrichs, 
Preussentum und Pietismus: Der Pietismus in Brandenburg-Preussen als religiös-Soziale Reformbewegung. Göttingen, 1971.

-. The Historical Essays of Otto Hintze. New York: Oxford University Press, 1975.

Hohrath, Daniel. The Uniforms of the Prussian Army under Frederick the Great. Berlin: Militaria Verlag, 2011.

Hoock, Holger. Scars of Independence: America's Violent Birth. New York: Crown, 2017.

Houlding, John Fit for Service: The Training of the British Army, 1715-1795. Oxford: Oxford University Press, 1981.

Howard, Michael. War in European History New York: Oxford University Press, 2009.

Hulme, Peter. et al, eds., The Cambridge Companion to Travel Writing. Cambridge: Cambridge University Press, 2013.

Iida, Takashi. "Coping with Poverty in Rural Brandenburg: The Role of Lords and State in the Late Eighteenth Century." In Public Goods Provision in the Early Modern Economy: Comparative Perspectives from Japan, China, and Europe, edited by Tanimoto Masayuki and Wong R. Bin, 118-29. Oakland, California: University of California Press, 2019

-------------. Bauern, Bürger und Soldaten. Quellen zur Sozialisation des Militärsystems im preußischen Westfalen 1713-1803. 2. Münster: De Gruyter, 1992.

Kloosterhuis, Jürgen. "Donner, Blitz und Bräker - der Soldatendienst des ,armen Mannes im Tockenburg' aus der Sicht des preußischen Militärsystems.” In Schreibsuchtautobiografische Schriften des Pietisten Ulrich Bräker (1725-1798). Göttingen: Vandenhoeck \& Ruprecht, 2004.

Militär und Gesellschaft in Preußen-Quellen zur Militärsozialisation, 17131806. 3. Frankfurt: Peter Lang, 2014.

Kocka, Jurgen. "German History before Hitler: The Debate about the German Sonderweg." Journal of Contemporary History 23, no. 1 (1988) 3-16.

Koser, Reinhold. Geschichte Friedrichs des Großen. Stuttgart \& Berlin: J.G. Cotta, 1921.

Landa, Manuel de War in the Age of Intelligent Machines. New York, NY: The MIT Press, 1991.

Langford, Paul. A Polite and Commercial People: England, 1727-1783. Oxford, 1989: Oxford University Press, 1989. 
Layne, Darren. "Layne on Massie and Oates," The Scottish Historical Review, Volume 99. No. 2, (October 2020), 316-318.

Laslett, Peter. The World We have Lost: Further Explored. London, Routledge, 2004.

Leggiere, Michael V. Blücher: Scourge of Napoleon. Norman, University of Oklahoma Press: 2014.

Leibetseder, Mathis. Kavalierstour - Bildungsreise - Grand Tour: Reisen, Bildung Und Wissenserwerb in Der Frühen Neuzeit. Mainz: Leibniz-Institut für Europäische Geschichte, 2013.

Levy, Jack S. War in the Modern Great Power System: 1945-1975. Lexington, KY: University Press of Kentucky, 1983.

Linn, Edward, "The Battle of Culloden 16 April 1746 as described in a Letter from a soldier in of the Royal Army to His Wife," JSAHR, 1 (1921-2), 21-4.

Lynn, John. The Bayonets of the Republic Motivation and Tactics in the Army of Revolutionary France, 1791-94. Boulder: Westview Press, 1996.

Macaulay, Thomas B. The History of England from the Accession of James the Second. 5. London: 1848

Mackesy, Piers. The War for America, 1775-1783. Lincoln, University of Nebraska Press, 1964.

Marschke, Benjamin. Absolutely Pietist: Patronage, Factionalism, and State-Building in the Early Eighteenth-Century Prussian Army Chaplaincy. Leipzig: Max Niemeyer Verlag, 2005

Marshall, P.J. The Making and Unmaking of Empires: Britain, India, and America, c.17501783. Oxford, Oxford University Press, 2005

McCormack, Mathew. "Citizenship, Nationhood, and Masculinity in the Affair of the Hanoverian Soldier, 1756." The Historical Journal 49, no. 4 (2006): 971-93.

McKay, Derek. The Great Elector. Longman: New York, 2001.

Metcalf, Thomas. Ideologies of the Raj. Cambridge, Cambridge University Press 1995.

Mikaberidze, Alexander. The Napoleonic Wars: a Global History. Oxford: Oxford University Press, 2020.

Mingay, G.E. English Landed Society in the Eighteenth Century. London: Routledge, 1963.

Mintzker, Yair. The Defortification of the German City, 1689-1866. Cambridge: Cambrdige University Press, 2012. 
Mallinckrodt, Rebecca von. "There Are No Slaves in Prussia?" In Slavery Hinterland:

Transatlantic Slavery and Continental Europe, 1680-1850, edited by Brahm Felix and Rosenhaft Eve, by Bredeck Elizabeth, 109-32. Woodbridge, Suffolk, UK; Rochester, NY, USA: Boydell and Brewer, 2016.

Miakinkov, Eugene. War and Enlightenment in Russia: Military Culture in the Age of Catherine II. Toronto: University of Toronto Press, 2020.

Möbius, Katrin and Sascha Möbius. Prussian Army Soldiers and the Seven Years War: The Psychology of Honour, (London: Bloomsburg Academic, 2020) 90-92, 135-137.

Möbius, Sascha. Mehr Angst vor dem Offizier als vor dem Fiend? Eine mentalitätsgeschichtliche Studie zur preußischen Taktik im Siebenjährigen Krieg. Saarbrücken: VDM Verlag, 2007.

"Kriegsgreuel in den Schlachten des Siebenjährigen Krieges in Europa," in: Sönke Neitzel/ Daniel Hohrath (Hg.) Kriegsgreuel: Die Entgrenzung der Gewalt in Kriegischen Konflikten vom Mittelalter, (2008)

Muth, Jörg. Flucht aus dem Militärischen Alltag: Ursachen und Individuelle Ausprägung der Desertion in der Armee Friedrichs des Grossen: Mit Besonderer Berücksichtigung der Infanterie-Regimenter der Potsdamer Garnison. Freiburg Im Breisgau: Rombach Verl., 2003.

O’Shaunessy, Andrew J. The Men who Lost America: British Leadership, the American Revolution, and the Fate of Empire. New York: Yale University Press, 2014.

Oates, Jonathan. Sweet William or the Butcher? The Duke of Cumberland and the '45. London: Pen and Sword Military, 2008.

Ohlmeyer, Jane. "A Laboratory for Empire? Early Modern Ireland and English Imperialism.” in Ireland and the British Empire .ed. Kevin Kenny. New York: Oxford University Press, 2006.

Office of the General Council of the Department of Defense. Department of Defense Law of War Manual. Washington: 2016.

Planert, Ute. Der Mythos vom Befreiungskrieg: Frankreichs Kriege und der deutsche Süden: Alltag-Wahrnehmung-Deutung, 1792-1841. Schoenigh Ferdinand, 2007.

Plank, Geoffrey. An Unsettled Conquest: The British Campaign Against the Peoples of Acadia. Philadelphia, University of Pennsylvania Press, 2003.

Paoletti, Ciro. "War, 1688-1812," essay, in A Companion to Eighteenth-Century Europe. ed. Peter H. Wilson Oxford: Wiley Blackwell, 2014. 
Phillips, Jason. "Battling Stereotypes: A Taxonomy of Common Soldiers in Civil War History," History Compass 6, no. 6 (2008): 1417-1425.

Diehard Rebels: The Confederate Culture of Invincibility. Athens: University of Georgia Press, 2010.

Pichichero, Christy. The Military Enlightenment: War and Culture in the French Empire from Louis XIV to Napoleon. Cornell: Cornell University Press, 2017.

Pittock, Murray. The Myth of the Jacobite Clans: The Jacobite Army in 1745. Edinburgh: Edinburgh University Press, 2009.

Porter, Roy. English Society in the Eighteenth Century. London: Pelican Books, 1982.

Preuss, Johann D. E. Urkundenbuch zu der Lebensgeschichte Friedrichs des Großen. Berlin: Nauck, 1832-1834.

Reid, Stuart. 1745: A Military History of the Last Jacobite Uprising. Staplehurst: Spellmount, 1996.

Ritter, Gerhard. Europa Und Die Deutsche Frage. München: F. Bruckmann Verlag, 1948. Staatskunst Und Kriegshandwerk: Das Problem Des "Militarismus" in Deutschland. München: Oldenbourg, 1970.

Robitschek, Norbert. Hochkirch: Eine Studie. Wien: C. Teufen's Nachfolger, 1905.

Rodger, Nicholas A.M. Command of the Oceans: A Naval History of Britain, 1649-1815, London, W.W. Norton, 2005.

Salisch, Marcus von. Treue Deserteure: Das Kursächsische Militär Und Der Siebenjährige Krieg. München: R. Oldenbourg, 2009.

Schui, Florian. Rebellious Prussians: Urban Political Culture under Frederick the Great and his Successors. Oxford, Oxford Unviersity Press, 2013.

Schumann, Matt. "The end of the Seven Years' War in Europe," in The Seven Years War: Global Views. eds Mark Danely and Patrick Speelman. Boston: Brill, 2012.

Scott, Hamish. "The Seven Years War and Europe's Ancien Regime," War in History Volume 18, no. 4 (2011)

Sikoura, Michael. Discinplin und Desertion: Strukturprobleme militärischer Organisation im 18. Jahrhundert. Historische Forschungen 57. Berlin: Duncker und Humboldt, 1996.

Spring, Matthew H. With Zeal and with Bayonets Only: the British Army on Campaign in North America, 1775-1783. Norman: University of Oklahoma Press, 2010. 
Snape, Michael F. The Redcoat and Religion: the Forgotten History of the British Soldier from the Age of Marlborough to the Eve of the First World War. London: Routledge, 2008.

Smith, Hannah. "Politics, Patriotism, and Gender: The Standing Army Debate on the English Stage", Journal of British Studies, Volume 50, (2011) 48-75.

--.--.-. "The Army, Provincial Urban Communities, and Loyalist Cultures in England, Journal of Early Modern History, Volume 15, (2011) 139-158.

Sumner, Percy . "General Hawley's Chaos," Journal of the Society for Army Historical Research, Volume 26, No. 107, (Autumn, 1948) 91-94.

Szabo, Franz A.J. The Seven Years War in Europe, 1756-1763 (London: Pearson Longman, 2008), 423.

Thompson, E. P., The Making of the English Working Class. New York: Pantheon Books, 1964.

"The Moral Economy of the English Crowd in the Eighteenth Century." Past \& Present, no. 50 (1971): 76-136.

Wehler, Hans-Ulrich. Preussen ist wieder chic...: Politik und Polemik in Zwanzig Essays. Suhrkamp, 1983.

Wilson, Peter H. German Armies: War and German Politics, 1648-1806. London: University College London Press, 1998.

Wilson, Peter H. "Prusso-German Social Militarization Reconsidered," in Preussen, Deutschland, Und Europe 1701-2001. ed. Jürgen Luh, Vincent Czech, and Bert Becker Groningen. Institute for North and East European Studies, 2003.

Wilson, Peter H. The Thirty Years War: Europe's Tragedy. Cambridge, MA: Belknap Press of Harvard University Press, 2011.

Winter, Martin. Untertanengeist durch Militärpflict: Das Preussische Kantonsystem in brandenburgischen Städten im 18. Jahrhundert, (Bielefeld: Regionalegeschichte, 2005).

\section{Unpublished Dissertations:}

Backlund, Janne. "Rusthållarna i Fellingsbro 1684-1748 : indelningsverket och den sociala differentieringen av det svenska agrarsamhället." Ph.D diss. University of Uppsala, 1993

King, Stephen. "The 1782 British Army Reforms: Adoption of County Titles." MA thesis. University of Plymouth, 2011. 
Osman, Julia. "The Citizen Army of Old Regime France." Ph.D diss. University of North Carolina-Chapel Hill, 2010

Pimlott, John L. "The Administration of the British Army, 1783-1793" Ph.D diss. Leicester University, 1975

Röder, Tobias, "Professional Identity of Army Officers in Britain and the Habsburg Monarchy, 1740-1790." PhD diss. University of Cambridge, 2019.

Steppler, Glenn A. "The Common Soldier in the Reign of George III, 1760-1793." PhD diss. University of Oxford, 1984.

Storring, Adam. "Frederick the Great and the Meanings of War, 1730-1755" Ph.D diss. University of Oxford, 2018. 